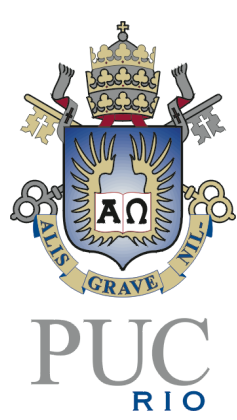

Vânia Lúcia Kampff

À Escuta da Linguagem:
Heidegger e Pessoa

Tese de Doutorado

Tese apresentada como requisito parcial para obtenção do grau de Doutor pelo Programa de Pós-graduação em Filosofia do Departamento de Filosofia da PUC-Rio.

Orientador: Prof. Luiz Camillo Osorio

Rio de Janeiro Março de 2020 


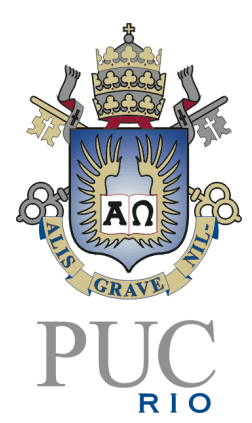

Vânia Lúcia Kampff

\section{À Escuta da Linguagem: \\ Heidegger e Pessoa}

Tese apresentada como requisito parcial para obtenção do grau de Doutor pelo Programa de Pós-graduação em Filosofia do Departamento de Filosofia da PUC-Rio. Aprovada pela Comissão Examinadora abaixo.

Prof. Luiz Camillo Osorio

Orientador

Departamento de Filosofia - PUC-Rio

Prof. Eduardo Jardim

Departamento de Filosofia - PUC-Rio

Prof. Gilvan Luiz Fogel

UFRJ

Prof. Bernardo Oliveira

UFF

Prof. Tito Marques Palmeiro

UERJ

Rio de Janeiro, 17 de Março de 2020. 
Todos os direitos reservados. É proibida a reprodução total ou parcial do trabalho sem autorização do autor, do orientador e da universidade.

\section{Vânia Lúcia Kampff}

Graduou-se em Letras (Licenciatura Plena - Português / Inglês) pela PUC-Rio em 1988. Cursou Teologia / Filosofia na PUC - Rio. Foi coordenadora executiva da Cátedra Carlo Maria Martini. Concluiu mestrado em 2015. Área de pesquisa em Filosofia Contemporânea, com estudos desenvolvidos em Martin Heidegger.

Ficha Catalográfica

Kampff, Vânia Lúcia

À escuta da linguagem: Heidegger e Pessoa / Vânia Lúcia Kampff; orientador: Luiz Camillo Osorio. - 2020.

217 f.; $30 \mathrm{~cm}$

Tese (doutorado) - Pontifícia Universidade Católica do Rio de Janeiro, Departamento de Filosofia, 2020.

Inclui bibliografia

1. Filosofia - Teses. 2. Experiência. 3. História. 4. Tempo. 5. Poesia 6. Linguagem I. Osorio, Luiz Camillo. II. Pontifícia Universidade Católica do Rio de Janeiro. Departamento de Filosofia. III. Título. 


\section{Agradecimentos}

Esta tese nasce do afeto, do páthos. Nasce a partir de palavras que chegam até nós, nos atravessam, convocam e, a partir desse encontro, algo surge, emerge. Palavras generosamente ofertadas ao longo desse trajeto que, quando lançadas, foram palavras-caminho a pavimentar o percurso e pelas quais serei sempre grata.

Ao professor e orientador Luiz Camillo Osorio pela acolhida ao meu projeto, pela presença, escuta e cuidado constantes em todos os momentos do caminho;

ao professor Eduardo Jardim pela amizade e pelas palavras, sempre sábias, a apontar o caminho;

ao professor Gilvan Fogel pela generosidade, sabedoria e acolhimento, sem os quais o caminho não seria o mesmo;

ao professor Steffen Dix, pesquisador da Universidade Católica Portuguesa, pelas mais variadas e tão pertinentes palavras-caminho ofertadas ao longo do percurso;

ao professor Jerónimo Pizarro, da Universidad de los Andes, Titular da Cátedra de Estudos Portugueses do Instituto Camões na Colômbia, pela abertura e presteza no envio da revista "Pessoa Plural - A Journal of Fernando Pessoa Studies";

ao meu marido, Carlos Adolfo Kampff, e aos meus filhos, Christian Kampff e Patrick Kampff, pelo amor, compreensão e amparo ao longo desses anos;

aos amigos da vida, da PUC-Rio e do IFCS, pela partilha de ideias, filosóficas ou não, no decurso do trajeto;

a todos os meus professores de Filosofia da PUC-Rio, cuja inteireza e coerência de propósito ajudaram a formar minha escuta ao caminho filosófico;

ao Departamento de Filosofia da PUC-Rio, desde sempre abrigo para o livre pensar;

à Edna Sampaio, à Diná Lúcia de Jesus Santos e ao Daniel, pela prontidão de todos os dias;

ao CNPq e à PUC-Rio, pelos auxílios concedidos, sem os quais esta pesquisa não poderia ter sido realizada;

por fim, mas antes de tudo, ao Deus da Vida, que pela fé foi a Luz que iluminou a totalidade do caminho. 


\section{Resumo}

Kampff, Vânia Lúcia; Osorio, Luiz Camillo. À escuta da linguagem: Heidegger e Pessoa. Rio de Janeiro, 2020. 217p. Tese de Doutorado Departamento de Filosofia, Pontifícia Universidade Católica do Rio de Janeiro.

A tese "À escuta da linguagem: Heidegger e Pessoa" busca, como o título sugere, uma aproximação entre o pensamento filosófico de Martin Heidegger e a linguagem poética de Fernando Pessoa acerca da linguagem originária. Buscamos desenvolver um estudo que tem como premissa o pensamento deixado pelo pensador-poeta desdobrando-se na linguagem do poeta-pensador. Da sombra desta inaparente relação, vislumbramos um caminho que desvela o entrelaçamento dos diversos fios da escrita de um e da poesia de outro na construção pensante e poética da linguagem originária, entendida a partir de uma experiência fundadora de linguagem. Trata-se de um dizer que faz aparecer, lugar em que a palavra é princípio de realidade, um aparecer que em sua imediatidade se faz linguagem originária, se faz poética da linguagem, o lugar do dizer. Ambos, filósofo e poeta, nos fazem entender que nosso estar no mundo é totalmente perpassado por uma experiência de sentido, na qual já estamos sempre inseridos. Nisso, há algo que se faz desde um imperativo vital: o homem desaparece, há apenas a entrega, o abandono à dimensão da transcendência, há apenas a espera e a escuta a desdobrarse em abertura, de modo a dar vazão ao outro que o acomete a convocá-lo à consagração do instante.

\section{Palavras-chave}

Experiência; história; tempo; poesia; linguagem. 


\section{Abstract}

Kampff, Vânia Lúcia; Osorio, Luiz Camillo (Advisor). Listening to Language: Heidegger and Pessoa. Rio de Janeiro, 2020. 217p. Tese de Doutorado - Departamento de Filosofia, Pontifícia Universidade Católica do Rio de Janeiro.

The dissertation "Listening to language: Heidegger and Pessoa" seeks, as the title suggests, to bring Martin Heidegger's philosophical thinking closer to Fernando Pessoa's poetic language on the quest of an original language. We seek to develop a study that has, as its premise, the thought left by the thinker-poet unfolding in the language of the poet-thinker. From the shadow of this inapparent relationship, we envision a path that unveils the interweaving of the various strands of the writing of one and the poetry of the other in the thinking of the poetic construction of an original language, understood from a founding experience of language. It is a saying that makes it appear, a place where the word is the principle of reality, an appearing that in its immediacy becomes original language, becomes poetics of language, the place of saying. Both philosopher and poet make us understand that our being in the world is totally permeated by an experience of meaning, in which we are always inserted. On this, something happens from a vital imperative: man disappears, there is only surrender, abandonment to the dimension of transcendence, there is only waiting and listening unfolding in openness, so as to give vent to the other who summons to the consecration of the instant.

\section{Keywords}

Experience; history; time; poetry; language. 


\section{Sumário}

1. Introdução 9

$\begin{array}{ll}\text { 1.1. O mundo pessoano } & 21\end{array}$

2. O tempo da noite do mundo 26

2.1. A cadência da técnica 38

2.2. O tom da técnica 54

2.3. A voz da técnica 60

3. À escuta do silêncio 69

3.1. A angústia: perdendo para encontrar $\quad 72$

3.1.1. Mergulhando em águas mais profundas 86

3.1.2. O nada que é tudo 99

3.2. Corporeidade: vida se fazendo vida 123

4. A saga poética 150

4.1. Antes do nome 175

4.2. O tempo da história ou a história do tempo da poesia 197

5. Considerações finais 204

6. Referências Bibliográficas 210 
And so each venture Is a new beginning, a raid on the inarticulate With shabby equipment always deteriorating In the general mess of imprecision of feeling, Undisciplined squads of emotion. And what there is to conquer By strength and submission, has already been discovered Once or twice, or several times, by men whom one cannot hope To emulate - but there is no competition There is only the fight to recover what has been lost And found and lost again and again: and now, under conditions That seem unpropitious. But perhaps neither gain nor loss. For us, there is only the trying. The rest is not our business. 


\title{
Introdução
}

\author{
What we call the beginning is often the end \\ And to make an end is to make a beginning. \\ The end is where we start from. And every phrase \\ And sentence that is right (where every word is at home, \\ Taking its place to support the others, \\ The word neither diffident nor ostentatious, \\ An easy commerce of the old and the new, \\ The common word exact without vulgarity, \\ The formal word precise but not pedantic, \\ The complete consort dancing together) \\ Every phrase and sentence is an end and a beginning, \\ Every poem an epitaph. \\ - $\quad$ T. S. Eliot ${ }^{l}$
}

Palavra certa, exata, precisa, diz Eliot, na quarta parte do famoso poema "Four Quartets", ao se referir à palavra como princípio e fim de cada poema. Parece simples o simples comércio do velho e do novo. Não! A lida com a palavra é dura. Morrer e nascer em cada palavra é sua sina. O poeta vive e morre por isso. A palavra é o seu ofício. Ele é atravessado pelas palavras, convocado por elas, e, a partir desse encontro, o par perfeito - o consorte completo, como ele mesmo diz - surge, emerge, na eterna dança dos versos. Quando isso acontece, quando a palavra certa, exata, precisa, irrompe - a linguagem fala! Também nós, em nossa fragilidade, fomos trespassados por palavras: palavras que nos instigaram, acolheram, nortearam. Palavras que encheram nossa vida de sentido e foram luz para o caminho. Se, como diz Eliot, o que chamamos de princípio é muitas vezes o fim, e o fim é de onde partimos, iniciamos esta travessia com as perguntas: de onde partimos? O que motivou esta escrita?

Partimos de uma pergunta que Heidegger deixou como suas últimas palavras, no escrito de 1954, intitulado Que chamamos pensar?, por nós analisado em nossa dissertação de mestrado. A pergunta dizia: “É o pensar capaz de acolher, isto é, de prestar atenção a essa dádiva para, no légein, confiá-la num dizer ao falar original da língua?"2 Nela, o pensador se refere a uma dádiva, à dádiva de acolher

\footnotetext{
${ }^{1}$ ELIOT, Poemas, p.290-293. Tradução de Caetano W. Galindo: "O que chamamos de princípio muitas vezes é o fim / E criar um fim é criar um princípio. / O fim é de onde partimos. E cada frase / Cada sentença justa (onde cada palavra está em casa, cuidando de apoiar as outras, Palavra nem embaraçada nem pomposa, / Comércio simples do velho e do novo, / A palavra comum exata sem vulgaridade / A palavra formal precisa e não pendente, / Um madrigal completo que dança em conjunto) / Cada frase e cada sentença é um fim e um princípio, / Cada poema, epitáfio."

${ }^{2}$ HEIDEGGER, Que chamamos pensar? [inédito], p.203.
} 
e pronunciar a Palavra. Sim, com maiúscula, pois não se trata de uma palavra qualquer, mas, da Palavra. Da Palavra que está em casa. Da Palavra que é princípio, gênese. Nossa escrita se volta para o dizer das palavras, para o horizonte da própria linguagem, lugar em que tanto a filosofia quanto a poesia habitam na medida em que buscam ouvir as palavras nelas mesmas, e de tal forma que esta recepção as coloca em sintonia com aquilo que a palavra diz.

Como dissemos, partimos de uma inquietação de Heidegger. Lembremos que a pergunta supramencionada é um pensamento tardio do filósofo. Portanto, ali, o pensador já havia se aproximado daquilo que, em carta a Hannah Arendt, ele confessa serem "as coisas propriamente dignas de serem pensadas." ${ }^{3}$ Entretanto, isto não significa uma evolução. Linguagem e poesia andaram sempre juntas no pensamento de Heidegger. Além do escrito que demarca o nosso ponto de partida, é possível perceber que, nos textos sobre poesia, o pensar do filósofo é sempre acompanhado ou precedido pela questão da linguagem, como se esta fosse tomada como uma porta de entrada para aquela. Apesar de a poesia ser abordada em sua essencialidade apenas a partir de 1934 com o curso sobre Hölderlin, inúmeros são os escritos, palestras e conferências dedicados à linguagem e à poesia na trajetória do filósofo. Já em Ser e Tempo, vamos encontrar um breve olhar do pensador sobre a questão da interpretação poética em relação à analítica existencial do Dasein. Ali, no §5, Heidegger questiona se na poesia buscou-se uma interpretação originariamente existencial ou uma análise existenciária. Ao distinguir o plano ontológico do plano ôntico para a interpretação, o filósofo coloca que somente a partir da analítica existencial é que a poesia poderia ser liberada para uma interpretação originária. Mais à frente, no §34, dedicado à linguagem, Heidegger se refere à comunicação das possibilidades existenciais da disposição como uma meta explícita da fala "poética." disposições afetivas estão intrinsecamente ligadas. Lembremos ainda que no $\$ 29$ o pensador se refere ao caráter essencial da disposição como o "modo existencial básico da abertura originária de mundo." ${ }^{5}$ Em suma: é a disposição que constitui existencialmente a abertura de mundo e cabe ao dizer poético comunicá-la. Apesar

\footnotetext{
${ }^{3}$ ARENDT; HEIDEGGER, Hannah Arendt - Martin Heidegger: Correspondência 1925/1975, p.96. Itálicos do autor.

${ }^{4}$ Cf. HEIDEGGER, Ser e Tempo, p.225. Aspas do autor.

${ }^{5}$ Cf. Ibidem, p.196. Itálicos do autor.
} 
de não se aprofundar na investigação - seu objetivo era apenas o de apontar o lugar ontológico do fenômeno da linguagem -, podemos assumir que o olhar de Heidegger já esboçava uma antecipação positiva daquilo que ocuparia mais tarde o seu pensamento.

Será mesmo a partir do ano de 1934, com o primeiro curso de Heidegger sobre Hölderlin, que a poesia vai tornando-se lugar comum em seu pensar. Além dos cursos sobre os hinos "Germania" e "O Reno" no semestre de inverno de 1934/35, podemos elencar os cursos sobre os hinos "Recordação" no inverno de 1941/42, “O Ister” no verão de 1942 e o curso Introdução à Filosofia: Pensamento e Poesia no inverno de 1944/45. O livro Explicações da Poesia de Hölderlin, que reúne escritos de 1936 a 1968, também nos orienta para a essencialidade que a poesia assumiu no pensar de Heidegger. Além dos escritos acima mencionados, ainda temos os textos: "Pra que poetas?", de 1946; "O homem poeticamente habita...", de 1951; e o livro $A$ caminho da linguagem que reúne cursos, conferências e publicações, que vão de 1950 a 1959, e que versam sobre o tema da linguagem.

É notório o fato de que Heidegger se ocupou com a poesia dos grandes poetas alemães, especialmente Hölderlin, Rilke e Trakl. Foram eles, particularmente o primeiro, que serviram de esteio ao pensar do filósofo alemão para falar do retorno à casa: o lugar de reencontro e proximidade com a origem, de desdobramento do essencial, cuja a morada é a proximidade do ser. Muito foi dito sobre o encontro do pensar de Heidegger com os poetas alemães. Todavia, não trilharemos esta mesma estrada. Nossos passos seguem a trilha deixada por um poeta português do séc. XX: Fernando Pessoa. Um poeta que destinou sua vida a escrever, quase nada publicou ${ }^{6}$, e que, por ser muitos, reúne em sua heteronímia uma riqueza única. Escrevendo-se tornou-se expressão máxima do ato criativo. Suas poucas e frustradas tentativas de publicação não foram capazes de frear o impulso vital pelo qual foi tomado. Grande parte do que foi e fez foi trancafiado em

\footnotetext{
${ }^{6}$ Em nota autobiográfica de 1935, ano de sua morte, Pessoa nos revela o total de sua publicação: "Obras que tem publicado: A obra está essencialmente dispersa, por enquanto, por várias revistas e publicações ocasionais. O que, de livros ou folhetos, considera como válido, é o seguinte: '35 Sonnets' (em inglês), 1918; 'English Poems III’ e 'English Poems III' (em inglês também), 1922, e o livro 'Mensagem',1934, premiado pelo Secretariado de Propaganda Nacional, na categoria 'Poemas'. O folheto 'O Interregno', publicado em 1928, e constituindo uma defesa da Ditadura Militar em Portugal, deve ser considerado como não existente. Há que rever tudo isso e talvez que repudiar muito." (Cf. PESSOA, Escritos Íntimos, Cartas e Páginas Autobiográficas, p.252).
} 
uma tal arca que, quando encontrada, desvelou ao mundo mais de vinte e sete mil documentos. Pessoa é uma coisa grande dentre as grandes coisas, talvez o maior poeta da modernidade. Como todos os grandes, nasceu, escreveu e morreu. Deixou, além de seus poemas, textos em prosa e inúmeras cartas a amigos, e, são elas, juntamente com os poemas, que balizarão a nau de nossa travessia. Não que não nos interesse as exegeses deixadas por tantos autores e críticos. Alguns estarão ao nosso lado. Mas, à frente, como guia, teremos o próprio Pessoa. Não se trata de uma travessia simples. Vemos, com Eduardo Lourenço, que

uma obra de gênio não é um pasto todo preparado para a ruminação obrigatória da 'cultura'. É um desafio e até um precipício para quem não tem asas para atravessar o natural abismo que ela representa. [...] e em princípio ninguém as tem quando o gênio aparece, salvo os que consentem o atravessar servindo-se das asas dele. Não temos e nem queremos outro guia que o próprio Pessoa. Recentemente, um de seus clássicos exegetas admitiu a hipótese de ser ele o seu mais lúcido comentador. ${ }^{7}$

Neste sentido, nos colocamos diante do desafio de ler Pessoa a partir dele próprio. Mesmo servindo-nos das asas do poeta, talvez (e certamente) não fiquemos à altura dos grandes exegetas, mas, ao menos, será um caminho genuíno, trilhado no exercício do pensamento.

Não nos deteremos em uma análise literária como o tema poderia deixar transparecer. Nosso tema é o da própria linguagem poética como possibilidade de um falar original da língua. Para tanto, procuraremos nos acercar da poesia pessoana através de uma abordagem fenomenológica-hermenêutica - que se volta para as coisas mesmas e, ao mesmo tempo, leva em conta uma compreensão interpretativa -, buscando nas palavras aquilo que é o seu mais próprio. Isto significa ler as poesias desde elas mesmas e nelas mesmas, de modo que nesta leitura aflore a sua própria medida. Sempre tendo em mente que, por se tratar de uma interpretação fenomenológica, a própria fenomenologia em sua finitude é limitada. O que não significa dizer que haja nisso alguma carga negativa, mas, apenas que, por ter um modo de ser que é finito, a fenomenologia se aquiesce com o que é possível, com o que é bom. Portanto, nada além do que ela mesma pode ofertar. Quanto ao aspecto interpretativo, concordamos com Gadamer, no escrito "Sobre o Círculo da Compreensão", quando diz que: “[...] Quem quiser compreender um texto está [...] disposto a deixar que ele diga alguma coisa. Por

\footnotetext{
${ }^{7}$ LOURENÇO, Pessoa Revisitado, p.26.
} 
isso, uma consciência formada hermeneuticamente deve ser de antemão receptiva à alteridade do texto." $\mathrm{O}$ filósofo continua:

Essa receptividade não pressupõe, no entanto, uma 'neutralidade' quanto à coisa, nem um anulamento de si mesmo, incluindo a apropriação seletiva das próprias opiniões e preconceitos. Há que se ter consciência dos próprios pressupostos a fim de que o texto se apresente a si mesmo em sua alteridade, de modo a possibilitar o exercício de sua verdade objetiva contra a opinião própria. ${ }^{9}$

Sabemos que esta não é uma tarefa fácil e pode parecer presunçosa. Ainda assim, é preciso que se advirta: alguma desmedida poderá ocorrer de nossa parte, não no sentido de fazermos uma aproximação forçada ou idealizarmos aquilo que Pessoa estivesse a dizer, mas, sobretudo, por almejarmos trazer à luz aquilo que a obra nos evoca, aquilo que enxergamos com tamanha beleza e eloquência que nos faz entender que parece não haver poeta com maior ressonância com o pensar de Heidegger do que Pessoa. Apesar de nada sabermos desta interlocução conhecemos apenas o apreço de Pessoa por Nietzsche -, vislumbramos um caminho que pode ser trilhado e que desvela, da sombra desta inaparente relação, o entrelaçamento dos diversos fios da escrita filosófica de Martin Heidegger e da poesia de Fernando Pessoa na construção pensante e poética da linguagem. Ainda que não se trate de aplicarmos a filosofia do pensador alemão à obra do poeta português e, muito menos, de impormos uma teoria sobre a obra pessoana, buscamos desenvolver um estudo sobre a questão da linguagem originária que tem como premissa o pensamento deixado pelo pensador-poeta desdobrando-se na linguagem do poeta-pensador. Isto significa que o caminho será delineado pelo pensar de Heidegger e percorrido pela palavra poética de Pessoa, na medida em que ambos parecem dizer o mesmo. Entretanto, é preciso uma outra advertência: não estamos nos referindo ao dizer poético como um gênero literário ou mesmo como a arte de compor em versos. Não! Nos apropriamos das palavras de Fogel, que faz um excelente esclarecimento sobre o modo originário do poetar:

Trata-se, aqui, de entender a poesia, o poético, como uma dimensão do humano, do viver ou existir, na qual, desde a qual a linguagem se faz experiência (abertura, ekstase - daí afeto, páthos) e então abre a possibilidade e mesmo a necessidade do dizer, da palavra tornar-se o lugar e a hora em que o real se faz real, autenticamente (i.e., in statu nascendi) se realiza, ou seja, mostra-se, aparece, torna-se visível como tal, na sua própria gênese - i.e., como palavra ou dizer, desde palavra ou dizer; no dizer, como dizer. Isso assim é linguagem como real poiésis, como poieo - fazer,

\footnotetext{
${ }^{8}$ GADAMER, "Sobre o Círculo da Compreensão", in:

${ }^{9}$ Ibidem. , Verdade e Método II, p.76.
} 
produzir, criar, gerar. Assim compreendida, pois, a poesia e poética falam de toda linguagem fundadora, instauradora, e, então, não se trata exclusivamente da linguagem dos "poetas" e da "poesia", mas esta é igualmente a linguagem do pensamento, da filosofia [...] enfim, toda linguagem que, desde e como experiência, mostra, torna visível, e assim, funda real, em sua gênese ou movimento de realização. De novo, geração, gênese. ${ }^{10}$

Trata-se, portanto, de entendermos o dizer poético a partir de uma experiência fundadora de linguagem, lugar onde a beleza revela e faz brilhar o que se encobre. Roland Barthes, em seu livro intitulado Aula, nos fala que "a literatura não diz que sabe alguma coisa, mas [...] que ela sabe algo das coisas." 11 Ao que acrescentaríamos: porque Pessoa é este que sabe algo das coisas, sua poesia faz verter em palavras o mais simples: a coisa como coisa - uma esteira em que são as coisas mesmas que se impõem pela sua presença e adquirem um estatuto de verdade no desenrolar contínuo do real. Trata-se de um dizer que faz aparecer, lugar em que a palavra é princípio de realidade, um aparecer que em sua imediatidade se faz linguagem originária, se faz poética da linguagem, o lugar do dizer. O título de nossa tese diz: À escuta da linguagem: Heidegger e Pessoa. Voltemo-nos, agora, para o caminho a ser percorrido.

Em nosso segundo capítulo, buscaremos contextualizar o "pensar poetante" de Heidegger e o "poetar pensante" de Pessoa de forma a circunscrever a proximidade do habitar comum ao pensador e ao poeta, delimitando, com isso, o início do sec. XX como um tempo marcadamente indigente. Nos referimos aqui a um momento em que o homem se encontra à margem de si mesmo e em completa falta de sintonia com o mundo. Profundamente atravessados por um quadro de perda de valores, Heidegger e Pessoa, cada um à sua moda, desempenham um papel decisivo e marcam de modo definitivo a físionomia do pensamento e da cultura da Europa neste momento. Esse é o pano de fundo que buscaremos delinear de modo a estabelecer os paradigmas que serviram de base para o pensar de um e o poetar de outro.

No sentido de demarcarmos a carência desse tempo, lançaremos mão dos seguintes textos de Heidegger: o primeiro é baseado no curso proferido na Universidade de Freiburg, após sua saída do reitorado, em 1934. A preleções que inicialmente haviam sido anunciadas com o título de "O Estado e a Ciência" foram

\footnotetext{
${ }^{10}$ FOGEL, O Desaprendizado do Símbolo, p.106. Itálicos do autor.

${ }^{11}$ BARTHES, Aula, p.19.
} 
mudadas para Lógica - A pergunta pela essência da linguagem. Relaciona-se a mudança ao abandono do reitorado por parte do filósofo. Todavia, ainda que o pensador tenha mudado o nome do curso, as questões políticas, tais como, o poder do Estado e o papel da universidade, estão presentes no texto e no contexto das aulas; o segundo é "O tempo da imagem do mundo", de 1938, onde a questão do mundo moderno se põe como um delineamento para algo que seria mais tarde uma questão fundamental para o pensador: a técnica; por fim, o texto "Ciência e Pensamento do Sentido", escrito em 1953, no qual o pensador faz uma extensa análise sobre o enquadramento e a inserção da ciência em todas as áreas de interesse do homem e as consequências que isso traz para o homem.

$\mathrm{Na}$ poesia pessoana, o ponto de partida para este tempo do mundo se dá através do testemunho de Vicente Guedes, Barão de Teive e Bernardo Soares, os quais são considerados, por Teresa Rita Lopes, os coautores do Livro do Desassossego ${ }^{12}$. Para Lopes, além do tríptico ser uma característica pessoana - os heterônimos também são três -,

há uma relação catártica que Guedes, Teive e Soares mantêm com Pessoa (estabelecendo autodiagnósticos que, através deles, o seu criador faz de si próprio, tentando purgar-se de medos e maleitas, do corpo e da alma). [...] Guedes, Teive e Soares figuram aí como a tripla presença que se aplica a contar Pessoa, através de seus escritos diarísticos e autobiográficos $\left[\ldots . .{ }^{13}\right.$

A compreensão de Lopes é bastante coerente se notarmos a similaridade na expressão de mundo que cada um desses autores carrega. Apesar dos estilos se diferenciarem, o conteúdo é bastante próximo e não faria nenhum sentido a repetição do mesmo tema, em distintas ocasiões, por apenas um autor. No livro organizado por Lopes, são os três autores que narraram a perda de sentido e aridez do início do séc. XX. São eles que nos fazem compreender todas as grandes questões que permearam a relação do homem com o seu mundo. O próprio Pessoa, Ricardo Reis e Álvaro de Campos, em sua fase decadentista, também são vozes a

\footnotetext{
12 Sabemos, através de Zenith, que o Livro do Desassossego nasce com a publicação, em 1913, de "Na Floresta do Alheamento", um ano antes do trio de heterônimos Caeiro, Campos e Reis. Tratase de uma obra que Pessoa teria trabalhado durante toda a sua vida. Zenith conta que, num primeiro momento, o livro foi atribuído ao próprio Pessoa, depois a Bernardo Soares, mas é, antes de tudo, um livro de vários autores. (Cf. ZENITH, "Introdução", in: PESSOA, Livro do Desassossego, p.1214).

${ }^{13}$ LOPES, "Introdução", in: PESSOA, Livro(s) do Desassossego, p.21. Doravante, sempre que os fragmentos aparecerem nas duas edições, colocaremos as paginações separadamente, sendo a edição de Zenith citada como Livro do Desassossego e a de Lopes como Livro(s) do Desassossego.
} 
expressar o desalento deste momento, sendo o último a própria personificação do niilismo, da desertificação e da aridez do mundo.

Na segunda parte do capítulo, o texto "A questão da técnica", publicado em 1953, pavimentará nosso caminho. Nele, Heidegger nos direciona para a noção de Ge-Stell que, grosso modo, é a reunião de dois domínios aparentemente distintos a ciência e a técnica -, e por isso, devem ser compreendidos através de um único termo. Apesar da relevância do tema, a questão da técnica nos interessa na medida em que, ao longo texto, o pensador tensiona fortemente o desencobrimento explorador da técnica, o qual ameaça a possibilidade de o homem "voltar-se para um desencobrimento mais originário e fazer assim a experiência de uma verdade mais inaugural" 14 , com as noções de poíesis e de alétheia, as quais tem a ver com um modo de desvelamento, uma produção que "conduz do encobrimento para o desencobrimento" 15 , e que serão tratados mais a frente.

No que diz respeito à técnica, será Álvaro de Campos que se afinará com esta temática. O poeta-engenheiro expressa apologeticamente o seu amor pelas máquinas e triunfo das engrenagens exaltando o perfume das fábricas que consuma o modus vivendi e a relação simbiótica do homem com a máquina. A poesia de Campos faz girar a roda do infinito da sanha de um fazer que conduz o homem a um processo de desumanização: ele é a máquina que move a máquina, o lugar de maior superficialidade da existência humana. Cenário que fatalmente leva o homem a uma apatia, a uma letargia.

Toda a questão da técnica nos conduz ao tédio, que é o páthos do início do séc. XX. Ainda que este tema seja brevemente tratado - aprofundaremos a angústia existencial, no capítulo seguinte -, não poderíamos nos furtar em fazer algumas considerações sobre este fenômeno. No que diz respeito ao tédio, nos debruçamos sobre as preleções de 1929 e 1930, intituladas Os Conceitos Fundamentais da Metafísica: Mundo - Finitude - Solidão, lugar em que Heidegger descreve três possibilidades para o fenômeno do tédio. Um outro texto que nos auxilia é "700 Anos de Messkirch", onde o pensador se dirige a sua cidade natal e descreve o fenômeno do tédio profundo como um abismo da existência humana.

\footnotetext{
14 HEIDEGGER, “A Questão Técnica”, in:

15 Ibidem, p. 16. , Ensaios e Conferências, p.31.
} 
O tédio profundo nos é cantado por Pessoa, Álvaro de Campos, Vicente Guedes e, especialmente, Bernardo Soares. Será com o guarda-livros que vamos encontrar a própria exacerbação e intensificação deste fenômeno a paralisar totalmente o movimento da vida - lugar em que o vazio e a indeterminação se instalam e se perde o sentido de ser.

Concluímos este capítulo com o tema da linguagem e sua relação com a técnica. O livro tratado neste percurso é Lógica - A pergunta pela essência da linguagem, de 1934. Voltamo-nos para a ciência da Lógica, que, ao se apresentar como a doutrina do pensamento correto, cujo traço essencial é enunciar algo sobre algo, determina um fechamento ao campo original da palavra, na medida em que algo é assumido a partir de concepções e proposições previamente dadas. Um segundo texto também nos ilumina o caminho. Trata-se da conferência Lingua de Tradição e Lingua Técnica, proferida em1962, onde Heidegger faz uma crítica ao pensamento de Humboldt, que, em última instância, nos remete ao caráter instrumental da língua, na medida em que esta é considerada uma ferramenta de comunicação e informação. O último texto de Heidegger a nos auxiliar neste segundo capítulo, "Pra quê poetas?", de 1946, nos abre a experiência do tempo da indigência vivida pelo poeta e a compreensão da necessidade do abismo para o encontro da essência.

Quanto à questão da linguagem instrumental, são as poesias de Pessoa e Álvaro de Campos que nos falam do símbolo, do sinal. Também Caeiro faz uma crítica contundente à linguagem atravessada de símbolos, que se torna basicamente um veículo a serviço da técnica. Este é o abismo do qual o poeta e a poesia emergem. É somente na passagem do sentido antropológico-instrumental para um sentido ontológico que a linguagem poética é capaz de nos levar ao domínio da verdade.

Nosso terceiro capítulo se volta para o caminho do dizer poético. O texto base por nós utilizado é Ser e Tempo, publicado em 1927. Trataremos do silêncio e da escuta como abertura ao mais próprio do Dasein - o existencial primordial daquele que primeiro compreendeu -, pois "somente quem já compreendeu é que poderá escutar." ${ }^{" 16}$ Nesta parte, nos deteremos também na tonalidade afetiva da

\footnotetext{
${ }^{16}$ HEIDEGGER, Ser e Tempo, p.227.
} 
angústia como parte da constituição existencial do Dasein para uma abertura originária e lugar privilegiado de possibilidade de se enxergar as polaridades do real. Não nos referimos ao estado psicológico da angústia, mas ao lugar em que o Dasein "[...] experimenta o ser do ente como nada." ${ }^{17}$ É a angústia originária que abre o mundo como mundo - lugar que abrange a totalidade de tudo que é e ultrapassa qualquer medida ôntica.

Quanto ao nosso poeta, a angústia deixa marcas indeléveis na poesia de Álvaro de Campos. Em sua última fase poética, que vai de 1916 até 1935, Campos vive a experiência do limiar, da desertificação, do vazio. Sua poesia fala da existência marcada pela fragmentação interior. É em Campos que vamos encontrar a ausência do nada e a experiência do limiar que beira a finitude. Também Pessoa, no Fausto, canta a paralisia e o horror que suspende o ânimo e o fluir da vida. No Livro(s) do Desassossego, Vicente Guedes e Bernardo Soares são vozes uníssonas a narrar a desconexão com o mundo, lugar da indiferença, da resignação, da inércia, do parado da angústia, da estranheza de não estar em casa, do oco e do vazio da vida. Entendemos que a experiência da angústia e do nada trazida por tantos poetas nos fala da própria abertura para o poetar - o lugar em que se instaura a linguagem e a poesia.

Atrelados à angústia, ainda nos voltaremos para a compreensão dos vocábulos experiência, phátos e transcendência, os quais também são determinantes para a compreensão de corpo e aísthesis. $\mathrm{O}$ que se busca, com as noções de experiência, corpo e aísthesis, é o ver e o aparecer do ser; algo que se dá primeiro e é determinante para os modos possíveis de vida ou existência. O corpo assume, pois, o lugar e a hora desse encontro com o mundo, o lugar e a hora da instauração de horizontes de sentido. Nos referimos aqui a uma visão de mundo livre de qualquer subjetividade. Não nos atemos ao corpo físico ou biológico, mas, aquilo que aparece onticamente como corpo já surge à luz de uma abertura primordial nomeada por Heidegger de existência, mundo, horizonte. Portanto, o horizonte da existencialidade do corpo não mais se refere ao âmbito da objetidade, mas, ao domínio do fenômeno, da dimensão da corporeidade (Leiblichkeit). A partir do escrito Seminários de Zollikon, de 1948, Heidegger nos fala que nesta dimensão

${ }^{17}$ BERARDINELLI et alii, Fernando Pessoa e Martin Heidegger: O Poetar Pensante, p.69. 
se dá um ultrapassamento privilegiado, por ele nomeado de transcendência, e neste ultrapassamento "reside a possibilidade e a necessidade da individuação mais radical." ${ }^{18}$ Nos referimos a algo que advém ao homem, o atravessa, dele se apropria, o transforma e o singulariza como um determinado homem. É somente a partir daí que o "eu” aparece, surge. O poeta atravessado por essa experiência, por aquilo que o ultrapassa e transcende, deixa-ser esse outro, essa diferença, e, com isso, é linguagem e poesia.

São os versos de Caeiro que nos ajudam a dialogar com o pensamento de Heidegger sobre a corporeidade. É na imanência do corpo da existência que o poeta sente o mundo. Trata-se de uma abertura cuja visão e escuta estão totalmente imbricadas na relação do poeta com as coisas. Caeiro é o olho que sente, a escuta que sente, o corpo que sente, nada além e nada aquém do que a própria imanência de cada coisa em seu desvelar de coisa. O guardador de rebanhos descreve a expressão mais radical e originária da corporeidade explicitada a partir de uma experiência inserida na existência. Isto significa uma corporeidade perpassada por uma relação de pura gratuidade, sem porquê ou para quê, sem de onde ou para onde - a perfeita vibração da imanência do corpo da existência a tocar o poeta. Seus versos nos fazem entender que nosso estar no mundo é totalmente perpassado por uma experiência de sentido, na qual já estamos sempre inseridos. Caeiro é o poeta da sensação. Sua pátria é o sentir. A relação do poeta com o todo que o cerca é direta. É a sensação o seu elemento mais próprio, aquilo que determina sua morada no mundo. Trata-se de um modo de ser em que o poeta, ao sentir, entra na própria coisa, e, com isso, a coisa se mostra nela mesma, em seu modo próprio de ser, em sua natureza. Há aqui algo que se faz desde um imperativo vital: o homem desaparece, há apenas a entrega, o abandono à dimensão da transcendência, há apenas a espera e a escuta a desdobrar-se em abertura, de modo a dar vazão ao outro que o acomete a convocá-lo à consagração do instante da poesia.

No quarto capítulo, avançaremos em direção à experiência da linguagem propriamente dita. Sabemos que o homem não habita na linguagem, encontra-se ainda na diáspora. A pátria deste habitar é, de acordo com Heidegger, Historial e se

\footnotetext{
${ }^{18}$ HEIDEGGER, Ser e Tempo, p.78.
} 
dá na História ${ }^{19}$ do mundo, se refere ao destino que une todos os homens, ao verdadeiro universalismo que é a morada Histórica do ser. Permeia esta questão uma temática bastante cara ao pensador: o Ereignis. Há que se dizer que este tema por si mesmo seria suficiente para uma tese. Heidegger, na segunda sessão do Protocolo sobre a conferência "Tempo e Ser", elenca todos os momentos em que o tema foi evocado e explicitado. Todavia, não abarcaremos a questão em profundidade. O tema do Ereignis nos interessa na medida em que isto que, segundo Heidegger, é Acontecimento apropria-se no dizer. Diz o filósofo: “A casa do ser é a linguagem porque como saga do dizer, ela é o modo do acontecimento apropriador" ${ }^{20}$. Desta forma, entendemos que o acontecimento apropriador é condição sine qua non para a compreensão da linguagem em sua essencialidade, pois é ali que pulsa aquilo de que a linguagem fala - "a mais presente de todas as coisas presentes" ${ }^{21}$. Trata-se, pois, de trazermos à luz a relação do acontecimento apropriador com a linguagem, e, em nosso caso, com a linguagem poética. A poesia torna-se, pois, envio para esse retorno à casa. É a poesia que reúne mortais e divinos, ela é a "justa a medida" que "traz o habitar para o seu aspecto fundamental."22. É a poesia a ponte que, quando inserida em seu sentido mais próprio, é a expressão daquilo que os gregos nomeavam poíésis, ou seja, aquilo que vem à presença e por si mesmo aparece. A poesia é a experiência de um vir a ser, é o passar da não presença a presença na medida em que revela e faz brilhar o que se encobre, que deixa a coisa aparecer. É a poesia ${ }^{23}$ - e, como condição necessária para esta, a linguagem - que nos dá a possibilidade do aberto e que mantém aberto o aberto do mundo. Revela-se nesta experiência da linguagem o acontecimento inaugural e fundador de toda e qualquer realidade, uma total relação com a coisa mesma. O poeta encontra aí o ser da palavra, a sua essência, e aquilo que emerge se dispõe como algo que simplesmente é. Encontramos subsídios para esta parte de nosso

\footnotetext{
${ }^{19}$ Heidegger estabelece uma distinção fundamental entre os termos Historie e Geschichte. Enquanto o primeiro designa para ele a história concebida em sua dimensão ôntica, historiográfica, relativa aos acontecimentos que se dão no âmbito do tempo cronológico, o segundo se destina apenas a uma dinâmica existencial de temporalização originária do Dasein. É esta segunda compreensão do termo que nos interessa e que doravante estará presente no escopo deste escrito.

${ }^{20}$ HEIDEGGER, A Caminho da Linguagem, p.215.

${ }^{21}$ HEIDEGGER, Que chamamos pensar? [inédito], p.7.

${ }^{22}$ HEIDEGGER, “... poeticamente o homem habita...”, in: , Ensaios e Conferências. p.172173.

${ }^{23} \mathrm{Em} A$ origem da obra de arte Heidegger afirma que: "toda a arte é, enquanto tal, na sua essência, poesia." (Cf. HEIDEGGER, Caminhos de Floresta, p.76).
} 
escrito em alguns textos de Heidegger publicados em Ensaios e Conferências e em A Caminho da Linguagem.

Entendemos que, de todos os outros pessoanos, Caeiro é o que mais se aproxima desse lugar ontológico da poesia pensado por Heidegger. Em Caeiro encontramos aquilo que poderíamos chamar de "o grau zero da poesia". Um dizer que se revela na forma pura, na fluidez da prosa livre, totalmente desprendida de uma linguagem figurada e sem nenhum ornamento. ${ }^{24} \mathrm{O}$ poeta

vem renomear o mundo, mas fá-lo como se tal acto, de natureza estética, fosse natural e não carecesse de metáforas, de figurações e de artifícios [...]; como se o poeta fosse capaz de ver e escrever o que vê [...] sem a mediação do intelecto pensante. $^{25}$

Isto significa uma relação de participação com as coisas. Através dessa comunhão, Caeiro resgata o caráter experiencial e opõe-se à busca de um fundamento único e definitivo para a vida. O poeta é o próprio afinamento com a abertura, com a própria medida que vincula à possibilidade, ao poder-ser de realidade aparecer enquanto $\mathrm{e}$ como dizer, enquanto e como linguagem. Ele é o testemunho desse acontecimento e celebração de verdade - um acontecimento de pura gratuidade que o atravessa, o transcende e restaura a experiência de mistério na fala e no discurso. Além da poesia de Caeiro, ajuda-nos nesta compreensão o livro do "filósofo" António Mora, $O$ Regresso dos Deuses.

Voltemo-nos, agora, para uma breve apresentação do universo pessoano que orbita neste escrito.

\subsection{O mundo pessoano}

O mundo pessoano é plural. "Eu sou uma antologia"26, escreveu o poeta em 1932. É notório o fato que Pessoa cultivava não somente os três heterônimos. Alberto Caeiro, Álvaro de Campos e Ricardo Reis não seriam seus únicos “outros”. Paralelamente, através de diversas estéticas, Pessoa deu à existência os semiheterônimos, de existência esporádica e inconstante, dentre eles, os mais

\footnotetext{
${ }^{24}$ Cf. OSAKABE, Fernando Pessoa - Entre Almas e Estrelas, p.32.

${ }^{25}$ PESSOA, 136 pessoas de Pessoa, p. 382.

${ }^{26}$ LOPES, Pessoa por Conhecer, p. 94.
} 
conhecidos são: Vicente Guedes, Barão de Teive e o Bernardo Soares. Além desses, temos ainda uma vasta genealogia de personas que, em lista elaborada por Teresa Rita Lopes, até o início dos anos 1990, contava com um total de 72 "outros”. A partir do estudo pioneiro de Lopes, o mosaico pessoano não parou de crescer. Este conjunto forma hoje uma lista de 136 figuras registradas nas mais de 30 mil folhas que compõem o espólio pessoano. ${ }^{27}$

A multiplicidade e a riqueza dessa antologia nos permitiram, como em um processo de curadoria poética que busca abrir sentido a partir de determinadas escolhas, caracterizar cada heterônimo ou semi-heterônimo como um mundo que se abre a partir de Pessoa. Trata-se, como em um gesto curatorial, de pensarmos Caeiro, Campos, Reis, Soares, Guedes, Teive e Mora como parte de uma totalidade fragmentada que não é menos. Ao contrário, é mais, na medida em que potencializa as relações que se constituem a partir do sentido que se abre e nunca se esgota em cada um. Daí o fato de termos decidido manter vivos os poetas de Pessoa, apesar de sabermos que tudo é ele! De modo a constituir o mundo que cada um ocupa neste universo, voltamo-nos agora para uma breve apresentação dos "outros" pessoanos:

ALBERTO CAEIRO nasce em Lisboa, em 16 de abril de 1889, perdeu o pai e a mãe cedo e vivia com uma tia-avó. O poeta só teve instrução primária, não teve profissão e viveu quase toda a sua vida no campo. Sua gênese no universo pessoano é narrada na famosa carta, de 1935, a Casais Monteiro. Por lá, somos informados que Caeiro aparece de súbito, em 14 de março de 1914, através dos versos de "O guardador de rebanhos" e que o poeta figura no mais alto patamar pessoano: é o mestre não só de Pessoa, mas de Campos e também de Reis. ${ }^{28}$ Caeiro é figura central neste mundo. São várias as vozes a falar de Caeiro: Ricardo Reis prefaciou sua obra poética e conta que "seus poemas são o que nele houve de vida. Em tudo mais não houve incidentes, nem há história." ${ }^{29}$ Tais palavras ressoam nos próprios versos do mestre, que escreve: "Se, depois de eu morrer, quiserem escrever minha biografia, / Não há nada mais simples. / Tem só duas datas - a da minha nascença e a da minha morte. / Entre uma e outra cousa todos os dias são meus."30 Álvaro de Campos fala que foi com Caeiro que aprendeu a ter clareza, equilíbrio e

\footnotetext{
${ }^{27}$ Cf. PIZARRO; FERRINI, “Apresentação”, in: PESSOA, 136 pessoas de Pessoa, p.13-19.

${ }^{28}$ Cf. PESSOA, Obras em Prosa, p.96-97.

${ }^{29}$ Idem, Páginas Íntimas e de Auto-Interpretação, p. 330.

${ }^{30}$ Idem, Obra Poética, p. 237.
} 
a escrever com alma. ${ }^{31}$ Pessoa, tal como Campos, "atribui ao Mestre um semblante divino e infantil, próprio de alguém sábio e inocente." ${ }^{32}$

ÁLVARO DE CAMPOS nasceu em Tavira, em 15 de outubro de 1890, às 13:30 da tarde. Segundo Pessoa, Campos teve uma educação formal de liceu, é muito viajado, explorou o Oriente e a Europa, tendo, inclusive, morado na Escócia, onde estudou engenharia mecânica e naval, em Glasgow. ${ }^{33}$ Por conseguinte, falava inglês perfeitamente e aprendeu latim com um tio que era padre. ${ }^{34}$ Quanto a sua gênese, o próprio Pessoa nos narra que "num jacto, e à máquina de escrever, sem interrupção nem emenda, surgiu a Ode Triunfal de Álvaro de Campos — a Ode com esse nome e o homem com o nome que tem." ${ }^{35}$ Em 1935, Pessoa já o apresentava como poeta e prosador ${ }^{36}$ e confessa que colocou nele toda a emoção que não dá nem a ele próprio e nem à vida.

RICARDO REIS nasceu em 1887, no Porto, vivia com uma tia-avó, foi educado num colégio de jesuítas onde aprendeu latim. Classicista por natureza, estudou grego por conta própria e era helenista. ${ }^{37}$ Reis era médico e, em 1919, por ser monárquico, expatriou-se para o Brasil. Como poeta, além de odes, concebeu elegias e epigramas. A contenção rítmica e a poética por trás dos versos, demonstram que Reis leu Horácio e poesia epigramática grega. Dos gregos, absorveu a apologia de uma vida simples e a valorização do instante presente. ${ }^{38}$ Sobre a data do nascimento de Ricardo Reis na alma pessoana, existem duas possibilidades: a primeira, em um provável texto de 1914, Pessoa escreveria: “O Dr. Ricardo Reis nasceu dentro de minha alma no dia 29 de janeiro de 1914, pelas 11 horas da noite" 39 ; a segunda, na famosa carta a Casais Monteiro, de 13 de janeiro de 1935, Pessoa teria dito: “Aí por 1912, salvo erro (que nunca pode ser grande), veio-me à ideia escrever uns poemas de índole pagã. [...] Esboçara-se-me, contudo, numa penumbra mal urdida, um vago retrato da pessoa que estava a fazer aquilo.

\footnotetext{
${ }^{31}$ Cf. PESSOA, Obra Poética, p.405.

${ }^{32}$ Idem, 136 pessoas de Pessoa, p.382.

${ }^{33}$ Cf. Idem, Páginas Íntimas e de Auto-Interpretação, p.411; idem, Obras em Prosa, p.96-98.

${ }^{34}$ Cf. Idem, 136 pessoas de Pessoa, p.397.

${ }^{35}$ Idem, Obras em Prosa, p.96.

${ }^{36} \mathrm{Cf}$. Idem, 136 pessoas de Pessoa, p.398.

${ }^{37}$ Cf. Ibidem, p. 420.

${ }^{38}$ Cf. Ibidem, p. 422.

${ }^{39}$ Idem, Páginas Íntimas e de Auto-Interpretação, p. 385.
} 
(Tinha nascido, sem que eu soubesse, o Ricardo Reis)." ${ }^{40}$ É nesta mesma carta que Pessoa relata a famosa criação de seus heterônimos e que também nos conta que colocou em Reis toda a sua disciplina mental. Sabemos ainda que Reis era discípulo de Alberto Caeiro - a ele coube a autoria do prefácio à obra do guardador de rebanhos -, e o oposto de Álvaro de Campos, com quem vivia em permanente disputa.

VICENTE GUEDES, segundo Teresa Rita Lopes, é a primeira personalidade literária pessoana a aparecer. A autora nos conta que "por volta de 1917, Pessoa decide passar a Vicente Guedes 'a pasta' dos trechos do Livro já escritos em seu próprio nome." 41 Apesar de Richard Zenith entender que Soares "herdou" a biografia de Guedes, Lopes afirma que são figuras completamente distintas na alma pessoana. De acordo com Lopes, Guedes possui uma linguagem requintada e uma acentuada propensão a rebuscar os seus estados de alma, é esnobe e visivelmente perverso, fatos que o distingue de Bernardo Soares.

O aristocrata BARÃO DE TEIVE nasce no universo pessoano em 1928. Teive aparece, tardiamente, na segunda fase do Livro do Desassossego. É concebido como o autor de um único manuscrito, A Educação do Estoico, o qual precede o seu suicídio na Quinta da Macieira, ao norte de Portugal. ${ }^{42}$ Sobre o fidalgo, o próprio Pessoa conta que seu estilo é o de um intelectual, conciso e despido de imagens. Teive pensa e escreve claro, domina bem suas emoções, mas não os sentimentos. ${ }^{43}$

BERNARDO SOARES é, segundo Lopes, a expressão tardia de Fernando Pessoa, mais especificamente, dos anos de 1929 até 1935, ano de sua morte. ${ }^{44}$ Zenith nos fala de Soares como o narrador principal do Livro do Desassossego, mas não o único. Para o autor, a fase mais tipicamente soariana também se limita ao período entre 1929 e 1935. Pessoa conta que Soares aparece sempre que ele está com sono e cansado. ${ }^{45} \mathrm{O}$ guarda-livros tem um estilo fluido de escrita, não domina suas emoções nem sentimentos e seu pensar já é um sentir. ${ }^{46}$ Segundo Pessoa,

\footnotetext{
${ }^{40}$ PESSOA, Obras em Prosa, p.96.

${ }^{41}$ LOPES, "Introdução", in: PESSOA, Livro(s) do Desassossego, p. 27.

${ }^{42}$ Cf. PESSOA, 136 pessoas de Pessoa, p.607.

${ }^{43} \mathrm{Cf}$. Idem, Páginas Íntimas e de Auto-Interpretação, p. 104.

${ }^{44}$ Cf. Idem, Livro(s) do Desassossego, p.243.

${ }^{45}$ Cf. Idem, Livro do Desassossego, p.13-14.

${ }^{46} \mathrm{Cf}$. Idem, Páginas Íntimas e de Auto-Interpretação, p.104.
} 
Soares pretendia ser poeta, mas é apenas um contista. "Seus versos são o lixo da sua prosa" ${ }^{47}$, ele diz.

De todos os outros pessoanos, ANTÓNIO MORA é aquele que mais se aproxima do status de heterônimo. Assim como Campos, Reis e o próprio Pessoa, Mora também é discípulo de Caeiro. Apesar de não ser poeta - era filósofo - Mora era tomado pela poesia. Segundo Álvaro de Campos, Mora passava a vida a ruminar Kant em busca de um sentido para a vida. Quando encontrou Caeiro encontrou a verdade. Deste encontro resultaram dois tratados: O Regresso dos Deuses e Prolegômenos a uma Reformação do Paganismo, obras em que Mora trata do papel preponderante de Caeiro na reconstrução do paganismo. Na alma pessoana, Mora aparece antes de todos os heterônimos. É Pessoa que afirma, em 1913: “Às vezes crio um filósofo, que me traça cuidadosamente as filosofias, enquanto eu, pagão, namoro a filha dele, cuja alma sou, à janela de sua casa." ${ }^{48}$ Segundo Osakabe, António Mora aparece com o papel de teorizar as questões fundamentais levantadas pelos heterônimos sobre questões que vão do paganismo ao legado de coisas deixadas pelo século XIX. Sobre esses temas, há uma alternância nos escritos do filósofo com a escrita do próprio ortônimo, de modo a salientar a "tentativa de intervenção de Pessoa nas questões filosóficas de seu tempo."49

Voltemo-nos, sem mais, para o caminho.

\footnotetext{
${ }^{47}$ PESSOA, Livro do Desassossego, p.23.

${ }^{48}$ MORA, "O regresso dos deuses", in: PESSOA, O Regresso dos Deuses, p.9-28.

${ }^{49}$ OSAKABE, Fernando Pessoa: Resposta à Decadência, p.94.
} 


\title{
2 \\ O tempo da noite do mundo
}

\begin{abstract}
"I have a metaphor [...] which I have never published, but kept to myself. I call it thinking without a banister, in German - Denken ohne Geländer. That is when you go up and down the stairs, you can always hold on to the banister, so that you don't fall down, but we have lost this banister. That is the way I tell it to myself. And this is indeed what I try to do."
\end{abstract}

- Hannah Arendt $t^{50}$

Pensar sem corrimão, diz a epígrafe. Não há sustento. Não há esteio. Não há chão. Falamos de um tempo em que se perdeu os tradicionais pilares religiosos, morais, políticos e filosóficos. A positividade e a prosperidade trazidas pela ciência moderna marcaram terminantemente uma indiferença às questões genuínas do homem. Cego que estava pelo progresso, o homem virou as costas para o próprio homem. Parece-nos um paradoxo dizer que o admirável mundo novo da ciência, cujo surgimento visava trazer melhorias para a vida, pôde representar o máximo da eficiência e, ao mesmo tempo, uma total ausência de sentido para a existência humana. Este é o tempo de Heidegger. Este é o tempo de Pessoa - de Vicente Guedes, Barão de Teive, Bernardo Soares, Alberto Caeiro, Álvaro de Campos e Ricardo Reis - vozes uníssonas que nos dão a saber a cadência da vida perdida, o descompasso do tempo do mundo, o esquecimento do mundo da vida. Cada um a seu modo dedicou sua vida a abrir veredas que permearam todas as grandes demandas de seu tempo ${ }^{51}$ e questionaram a relação do homem com o seu mundo.

Vicente Guedes pouco sabemos quem era ou o que fazia. Era amigo de Pessoa e, assim como ele, um nobre sem dinheiro a trabalhar no comércio. Ele escreve, no Livro do Desassossego, a "Autobiografia de quem nunca existiu", ainda assim, sua voz ressoa viva a narrar a perda do sentido de mundo e a aridez desse tempo. São as linhas escritas ao acaso em seu diário que nos dão a conhecer o mundo carente que o circunda. Assim ele diz:

\footnotetext{
${ }^{50}$ ARENDT, Thinking without a Banister, s.n. Tradução nossa: "Eu tenho uma metáfora [...] que eu nunca publiquei, mas guardei para mim mesma. Eu chamo de pensar sem corrimão, em alemão Denken ohne Geländer. Isto é, quando você sobe e desce as escadas, você sempre pode segurar o corrimão, para que você não caia, mas nós perdemos este corrimão. É assim que eu digo para mim mesma. E isso é realmente o que tento fazer."

${ }^{51}$ Cf. OSAKABE, Fernando Pessoa: Resposta à Decadência, p.46.
} 
Quando nasceu a geração a que pertenço, encontrou o mundo desprovido de apoios para quem tivesse cérebro, e ao mesmo tempo coração. $\mathrm{O}$ trabalho destrutivo das gerações anteriores fizera que o mundo, para o qual nascemos, não tivesse segurança que nos dar na ordem religiosa, esteio que nos dar na ordem moral, tranquilidade que nos dar na ordem política. Nascemos já em plena angústia metafísica, em plena angústia moral, em pleno desassossego político. [...] Ébrias de uma coisa incerta, a que chamaram "positividade", essas gerações criticaram toda a moral, esquadrinharam todas as regras de viver, e de tal choque de doutrinas, só ficou a certeza de nenhuma, e a dor de não haver essa certeza. ${ }^{52}$

Escolhemos as palavras de Guedes para inaugurar este capítulo na esperança de delinear este momento do mundo amplamente marcado por uma história de esquecimento e errância que constitui o início do século $\mathrm{XX}$ - um tempo de obscurecimento da luz, de decadência, de desassossego. Referimo-nos a um tempo indigente em que o homem se encontra à deriva de si mesmo, à margem de um pertencimento, em total desarmonia consigo e com o mundo. Herdeiro da destruição dos pilares da sociedade, sejam eles religiosos, morais ou políticos, o empregado do comércio narra a desolação de se sentir viver no tempo da noite do mundo. O pequeno trecho nos conta de um tempo desprovido de amparo não só para aqueles que viviam sob a égide da razão, mas também sob a cadência dos sentimentos e emoção. Todos sem apoio, sem corrimão. De pronto, perguntamos: qual é o pano de fundo que delimita este chão tão marcadamente niilista?

Não se trata de nos determos aqui em dados historiográficos, mas de trazermos à luz algo que, segundo Guedes, se reporta a um legado deixado por seus antepassados. Segundo ele, desde meados do séc. XVIII, a civilização sofre de uma doença progressiva. As gerações anteriores, ávidas por modelos e formulações disponibilizados pela razão e pela ciência, desmantelaram todos os fundamentos do cristianismo, reduziram os evangelhos a mitos e deixaram como herança uma profunda descrença na fé cristã. A positividade da ciência firmou-se como "a única força intelectual moderna - a única coisa capaz de se opor ao ensimesmamento cristão e romântico" ${ }_{53}$, nos diz Ricardo Reis, o poeta que também é médico.

Sabemos, entretanto, que a fé na ciência não preencheu as lacunas deixadas pela fé na religião, e que a questão do desmonte da crença religiosa remonta a um tempo anterior, tem sua origem já em Descartes. As elaborações filosóficas do cogito ergo sum e da res extensa acabam por implicar em uma reflexão sobre o

\footnotetext{
52 PESSOA, Livro do Desassossego, p.189-190; idem, Livro(s) do Desassossego, p.128-129.

53 PESSOA, Obra Completa de Ricardo Reis, p. 302; LOPES, Pessoa por Conhecer, p. 316.
} 
próprio homem e o mundo que o cerca consumando a libertação de determinados laços vigentes. O mundo até então exclusivamente teocêntrico, com Deus como o ponto para onde tudo convergia, passa ao modelo antropocêntrico, lugar em que o ser humano é considerado o centro do universo, sendo ele rodeado por todas as outras coisas. Bernardo Soares, morador da Baixa Lisboeta, ajudante de guardalivros num armazém da Rua dos Douradores e também coautor do Livro do Desassossego, reafirma esta compreensão, no preâmbulo ao "Livro dos Viajantes":

Nasci em um tempo em que a maioria dos jovens havia perdido a crença em Deus, pela mesma razão que os seus maiores a haviam tido - sem saber porquê. E então porque o espírito humano tende naturalmente para criticar porque sente, e não porque pensa, a maioria desses jovens escolheu a Humanidade para sucedâneo de Deus. ${ }^{54}$

Substituir Deus pelo Homem é, sem dúvida, uma compreensão bastante simplista. Como dissemos, existiam forças caminhando nesta direção desde Descartes, que paulatinamente se concretizaram em três esferas primordiais: efetivou-se o desligamento da autoridade do dogma e das normas da vida cristã; solidificou-se o desligamento do homem da natureza; e deu-se o desligamento do homem de suas comunidades originárias. Todas essas rupturas têm consequências determinantes para as gerações que se seguem. O afastamento do homem da vida cristã orientouo para descobertas e conquistas, onde o domínio das máquinas deu origem a uma relação totalmente modificada do homem com o mundo; a separação do homem da natureza fez com que esta fosse compreendida mecanicamente - algo que traz consequências para a própria compreensão do corpo: este é assumido como uma simples máquina; e, por último, a separação do homem de suas comunidades originárias criou uma nova ordem social e estabeleceu um novo conceito de Estado. ${ }^{55}$ As forças atuantes neste triplo desligamento faz do homem - desamparado de suas certezas metafísicas - um navegante sem rumo, cujo destino não é o de navegar, mas de chegar a um porto, como nos diz Guedes. A vida em negação, em descontentamento e desconsolo deixa o homem ávido por algum amparo. O empregado do comércio descreve uma sociedade completamente indisciplinada nos seus fundamentos culturais - espaço em que se desenrola a atividade espiritual e criadora do homem -, refém de novidades e que "com alegria ia à conquista de uma

\footnotetext{
${ }^{54}$ PESSOA, Livro do Desassossego, p.47; idem, Livro(s) do Desassossego, p.249.

${ }^{55}$ Cf. HEIDEGGER, Lógica, p.221.
} 
liberdade que não sabia o que era, de um progresso que nunca definira." ${ }^{56}$ Dentro desse escopo, devemos evocar a ciência como lugar de inserção em todas as formas da vida moderna, seja ela na economia, na indústria, na política, na comunicação ou até mesmo na guerra. Entendemos, a partir de Heidegger, que a ciência está inserida em todas as áreas de interesse do homem e que é de extrema importância sabermos deste enquadramento, pois toda esta questão será o gatilho para o advento da técnica que, mais do que ser definida como o controle e senhorio das máquinas e instrumentos, determina de modo fundamental não só a relação do homem com o mundo, mas, sobretudo, do homem consigo mesmo. ${ }^{57}$ Diante de um quadro tão niilista, profundamente descrente, Barão de Teive, fidalgo, de educação aristocrática e cuja única ocupação na vida é escrever, registra em suas páginas autobiográfico-diarísticas, intituladas “A Educação do Estoico", o seguinte trecho:

Pertenço a uma geração - supondo que essa geração seja mais pessoas que eu que perdeu a fé nos deuses das religiões antigas e a fé nos deuses das irreligiões modernas. Não posso aceitar Javé, nem a humanidade. Cristo e o progresso são para mim mitos do mesmo mundo. Não creio na Virgem Maria nem na eletricidade..$^{58}$

E, mais à frente, ainda acrescenta:

A conduta racional da vida é impossível. A inteligência não dá regra. E então compreendi o que talvez está oculto no mito da Queda: bateu-me no olhar da alma, como um relâmpago batera no do corpo, o terrível e verdadeiro sentido daquela tentação, pela qual Adão comera da Árvore dita da Ciência. Desde que existe inteligência, toda a vida é impossível..$^{59}$

Esta é uma questão que também não ficaria de fora do pensar do próprio Fernando Pessoa, que brada, em 1934:

A ciência, a ciência, a ciência...

Ah, como tudo é nulo e vão!

A pobreza da inteligência

Ante a riqueza da emoção! ${ }^{60}$

Ao inviabilizar a conduta puramente racional e rebaixar o estatuto da ciência ao mesmo da religião, Teive e Pessoa não estão apenas expressando uma inviabilidade para ambas. Suas vozes denunciam que o projeto civilizacional moderno fundado

\footnotetext{
${ }^{56}$ PESSOA, Livro do Desassossego, p.190; idem, Livro(s) do Desassossego, p.128.

${ }^{57}$ Cf. HEIDEGGER, "Ciência e Pensamento do Sentido", in: p.39-40.

${ }^{58}$ PESSOA, Livro(s) do Desassossego, p.215.

${ }^{59}$ Ibidem, p.223.

${ }^{60}$ Idem, Obra Poética, p.580.
} 
na ciência e na racionalidade também não deu conta de preencher as lacunas deixadas pela religião.

Toda esta questão também ressoará nos versos do poeta-engenheiro Álvaro de Campos que, em sua primeira fase ${ }^{61}$, personifica o decadentismo da modernidade, lugar em que o homem se encontra despido de todos os valores da tradição, da vigência marcada pela desertificação, assentada desequilibradamente entre a fé e a razão, uma vez que nem a religião e nem a ciência conseguem saciar a sede de absoluto. Ouçamos o desalento de sua voz neste poema intitulado "Barrow-on-Furness" que, mesmo sem data, é atribuído, na edição organizada por Jerónimo Pizarro, à primeira fase de Campos:

Deuses, forças, almas de ciência ou fé, Eh! Tanta explicação que nada explica! Estou sentado no cais, numa barrica, E não compreendo mais do que de pé.

Porque o havia de compreender?

Pois sim, mas também porque o não havia?

Água do rio, correndo suja e fria,

Eu passo como tu, sem mais valer...

Ó universo, novelo emaranhado,

Que paciência de dedos de quem pensa

Em outra coisa te põe separado?

Deixa de ser novelo o que nos fica...

A que brincar? Ao amor?, à indiferença?

Por mim, só me levanto da barrica. ${ }^{62}$

Através dos versos do poeta, vemos que não só a ciência ou a fé estão em jogo, mas a própria compreensão de verdade e realidade ficam comprometidas. $\mathrm{O}$ universo torna-se este "novelo emaranhado". Não há um real realmente real, mas, apenas as narrativas que constroem a realidade e que são dadas pelas mais diversas ciências.

${ }^{61}$ Sabemos, através de Jacinto do Prado Coelho, que Álvaro de Campos se distingue por ter três fases evolutivas em sua poesia, a saber: a fase do "Opiário" (1914); a do futurismo whitmaniano exuberantemente documentado na "Ode Triunfal" (1914), na "Ode Marítima" (1915), entre outros; e uma terceira fase, que vai desde "Casa branca nau preta", de 1916 até 1935. As fases ficam assim delineadas: a primeira seria uma fase decadentista, marcada "[...] pela embriaguez do ópio e dos sonhos de um Oriente que não há, do horror à vida [...]"; a segunda, modernista, ligada ao Futurismo e Sensacionismo, marcada pela "vitalidade transbordante, [...] um poeta da vertigem das sensações modernas, da volúpia da sensação, da energia explosiva [...]"; e a última fase, mais intimista, marcada pelo vazio, pela angústia e pela dor de existir, ou como diz Coelho: "A partir de 1916, Campos é o poeta do abatimento, da atonia, da aridez interior, do descontentamento de si e dos outros." (COELHO, Diversidade e Unidade em Fernando Pessoa, p.60-72).

${ }^{62}$ PESSOA, Obra Poética, p.422; idem, Obra Completa: Álvaro de Campos, p.332. 
Não há dúvida de que o mundo, caminhante que estava para a desdivinização, deixava em seu lugar um vazio imenso que, para muitos, não podia ser preenchido por nada. Bernardo Soares ainda acrescenta:

Trazem-me a fé como um embrulho fechado numa salva alheia. Querem que o aceite, mas que o não abra. Trazem-me a ciência, como uma faca num prato, com que abrirei as folhas de um livro de páginas brancas. Trazem-me a dúvida, como pó dentro de uma caixa; mas para que me trazem a caixa se ela não tem senão pó ${ }^{63}$

Não há senão a aniquilação e dissolução dos valores absolutos, a morte do sentido e o niilismo existencial. Sabemos que não há uma definição clara e unívoca para o termo Niilismo, são muitos os empregos do termo e as tentativas de explicitá-lo filosoficamente. Nos atemos à compreensão de Nietzsche que, grosso modo, emprega o vocábulo para expressar o desânimo, a decadência, a falta de sentido, a total ausência de referências e valores à caminhada humana. ${ }^{64}$ Referimo-nos, nas palavras de Heidegger, no escrito Nietzsche I, "ao acontecimento da desvalorização dos valores supremos, da aniquilação de todas as metas e da colisão de todos os juízos de valor." ${ }^{65}$ Em $A$ Vontade de Poder, cuja primeira coletânea de textos surge em 1901, Nietzsche se refere à falência e ruina dos valores cosmológicos, à derrocada das forças de sustentação de compreensão e interpretação de realidade que constitui o mundo, que têm como causa a crença nas categorias da razão, nos valores metafísicos fundamentados na lógica, os quais, guiados por princípios que se tornaram verdadeiros códigos de normatividade - a própria gênese da postura humana fundamentada no controle, estabilidade e asseguramento - , ordenam a moral do mundo e organizam toda a realidade como uma prescrição de como o mundo deve ser, sendo aquilo que não corresponde a esta ordenação: errado, insuficiente, irracional. Todas as ideias de totalidade, substância, ser, verdade estão todas colocadas em questão neste momento de esvaziamento de sentido da vida e da existência humana. ${ }^{66}$ Restam apenas, como diz Soares, embrulhos fechados, páginas em branco, dúvidas e corações vazios, um total desnorteamento gerado pela

\footnotetext{
${ }^{63}$ PESSOA, Livro do Desassossego, p.117; idem, Livro(s) do Desassossego, p.285-286.

${ }^{64}$ VOLPI, O Niilismo, p.8.

${ }^{65}$ HEIDEGGER, Nietzsche I, p.142.

${ }^{66}$ NIETZSCHE, Vontade de Poder, p. 31-33. A questão da perda de sentido também é pensada por Heidegger. Para ele, toda a história do pensamento ocidental é determinada pelo esquecimento do ser. Algo sobre este pensamento será dito no próximo capítulo. Entretanto, como este foi um tema largamente tratado em nossa dissertação de mestrado, entendemos que o caminho aqui percorrido não demanda a retomada do mesmo. Gostaríamos, apenas, de explicitar a base do pensamento de Heidegger, uma vez que, para o pensador, a perda do sentido do ser é determinada pelo esquecimento do ser que se consolida na própria ausência sobre a questão acerca do ser.
} 
ausência de referências tradicionais, que acabam por deixar no homem um estranhamento, um desconforto desalentador e sombrio. A falta de sentido demarca uma humanidade sem rumo, sem orientação, sem direção. Mas isso não é tudo. $\mathrm{O}$ que move e promove este estado de coisas é, como veremos, a submissão ao um dever-ser que por constituição ontológica não pode ser. É a sanha e a hýbris de querer o impossível, o que não pode, o que está além da possibilidade de ser. Os versos iniciais do poema "Opiário", escrito por Álvaro de Campos, em 1915, expressam com maestria a decadência e a busca pelo sentido da vida. Ouçamos um pequeno trecho:

É antes do ópio que a minh'alma é doente.

Sentir a vida convalesce e estiola

E eu vou buscar ao ópio que consola

Um Oriente ao oriente do Oriente. ${ }^{67}$

Os versos expressam a decadência, nos falam de uma alma doente que vive o extravio da cadência da vida. $\mathrm{O}$ desanimo e a falta de alento desaguam na busca pelo ópio como uma forma de conforto, de abrigo ao sofrimento. Oriente é nascente, lugar em que nasce o sol, a luz que traz o dia, que traz a vida. A busca do Oriente é a busca de orientação, de participação vital. O Oriente ao oriente do Oriente nos envia ao princípio do princípio do princípio. O começo de todos os começos. Tratase de um querer que busca o sentido do sentido do sentido, algo que tem uma estrutura de infinito e se distancia do horizonte do homem a cada vez que dele se aproxima. Campos nos conta de um sentido que nunca se dá, nunca se completa. Todo o modo de buscar fundamento e totalidade é o extremo da força que anseia pelo sentido, é a vida buscando se curar da doença de viver. Entretanto, por ser pura exposição à vida, é também um estado de fragilidade, que gera um sentimento de desencanto por não alcançar este algo a ser encontrado. O extremo da força debilita, estiola. A vontade do infinito que quer o impossível é a doença que assola o homem do início do século XX e a alma doente do poeta busca o ópio que consola.

A ausência de sentido e o estarrecimento diante da imensidão do cosmos já haviam sido prenunciados por Blaise Pascal, em 1670, nos fragmentos intitulados Pensamentos, quando ao refletir sobre a vida espanta-se e apavora-se ao contemplar a infinita vastidão desconhecida. Diz ele:

“[...] o pequeno espaço que preencho e mesmo que vejo, abismado na infinita

${ }^{67}$ PESSOA, Obra Poética, 301; idem, Obra Completa: Álvaro de Campos, p.36. 
imensidão dos espaços que ignoro e que me ignoram, apavoro-me e admiro-me por me ver aqui e não lá, pois não existe razão por que aqui e não lá, por que agora e não então." ${ }^{68}$

Sabemos que, por trás do pensamento de Pascal, há a busca por um Deus Absconditus a governar a natureza e o homem. Entretanto, nos importa perceber que, na nova cosmologia iniciada por Descartes, o homem não está mais em casa, o universo lhe é estranho e a própria compreensão racional de Deus, como vimos, terá eclipsado em um futuro próximo. Sem a força da transcendência, o sentido da existência se perde, desaparece, não há mais a plenitude de ser. Volpi, em $O$ Niilismo, ao analisar a aridez do mundo sem Deus, avança sobre o pensamento de Pascal e se detém sobre o desnorteamento provocado pela falta de referências que o niilismo traz ao espírito humano. Diz o filósofo italiano, ao se referir ao homem moderno:

"Agora, o universo the parece estranho ao seu destino individual assemelha-se a uma cela apertada em que sua alma se sente prisioneira, ou a uma infinitude sem nome que a intranquiliza. Diante do silêncio eterno das estrelas e dos espaços infinitos que lhe são indiferentes, o homem está só consigo mesmo. Não tem pátria." ${ }^{69}$

$\mathrm{Na}$ falta de um sentido existencial, o niilismo emerge. Trata-se de um hóspede perturbador que não pode ser despejado. Com ele, a morada do homem torna-se uma verdadeira cela. Aprisionado, instável, sem bússola, não há mais amparo para o homem, os pilares da busca pelo fundamento estão por demais fragilizados. Quando desaparecem os valores supremos e as respostas tradicionais ao porquê da vida, a falta de rumo e de sentido se instalam, a pobreza de valores se acomoda e a decadência faz morada. Quando tudo isso se perde, dá-se a derrocada do espírito humano. O homem moderno não habita sua pátria essencial, não está em casa, está encarcerado. A ideia da cela também ressoa nas palavras de Soares, que diz: "passar dos fantasmas da fé para os espectros da razão é somente ser mudado de cela." ${ }^{.70}$ Isto significa que a destruição dos antigos valores religiosos e a ocupação por novas crenças, sejam elas científicas, cujo saber nos oferece uma visão mecanicista da natureza e do universo, ou mesmo políticas, apresentadas através de diferentes regimes ou ideologias, tais como nacionalismo, chauvinismo, socialismo ou anarquismo, não mudam em nada o cenário niilista - tudo isso é mudar de cela. $\mathrm{O}$

\footnotetext{
${ }^{68}$ PASCAL, Pensamentos, p.25.

${ }^{69}$ VOLPI, O Niilismo, p. 16.

${ }^{70}$ PESSOA, Livro do Desassossego, p.72; idem, Livro(s) do Desassossego, p.439.
} 
niilismo aparece em várias esferas da vida humana, o âmbito do positivismo científico é apenas uma das possibilidades do niilismo se manifestar. De modo a aprofundarmos um pouco mais, busquemos a base desta questão.

O horizonte entrevisto por essa breve exposição possibilitará nos acercarmos daquilo que está no fundo da ciência moderna e entendermos porque ela coloca em questão o homem e o mundo que o cerca. Partimos da pergunta: em que consiste a essência da ciência moderna? Em primeiro lugar, devemos lembrar que a palavra essência deve ser aqui compreendida como gênese, geração, a força que move. Tendo isso em mente, podemos avançar e dizer que a essência daquilo que se chama ciência hoje é a investigação, que visa estabelecer um determinado plano para os processos naturais. Trata-se de um mecanismo que determina de que maneira se dá o avanço ao que é cognoscível, e cujo direcionamento se reporta ao rigor do método, que assegura de modo concreto o projeto científico. Isto significa dizer que todo o processo natural deve ser encaixado dentro de uma precisão e rigor próprio, os quais garantem através de cálculos aquilo que ele é. Não se trata apenas de observar o desenvolvimento de um experimento, mas, de um mecanismo de verificação exato da natureza, garantido por um projeto rigoroso, o qual quanto mais preciso mais exato é o seu resultado. É exatamente este - o resultado - que circunscreve e orienta o procedimento da ciência. Ter de fixar-se a partir dos próprios resultados é o caráter fundamental da investigação, que só tem caráter científico na medida em que é institucionalizada; só assim ela tem credibilidade. Com isso, através da primazia e eficácia dos procedimentos assegura-se aquilo que o objeto da investigação é, ou seja, só é real aquilo que pode ser calculado, mensurado e quantificado antecipadamente pelo projeto da investigação. Trata-se de uma compreensão atrelada a um método pelo qual a natureza é compreendida como objeto de uma previsibilidade universal. Isto significa dizer que a verdade das coisas é constituída através de uma objetividade da natureza apreendida apenas de forma clara, segura e indubitável para o sujeito que a representa e não como uma manifestação daquilo que vem à presença, daquilo que se mostra. No cálculo prévio, a natureza é interceptada e se torna objeto de um representar explicativo. E mais, só é matéria da ciência aquilo que pode ser buscado em sua objetividade. Tendo em vista a certeza como critério da verdade, o método exaure e elimina tudo o que é 
duvidoso, de modo a chegar a um fundamento absoluto e inabalável. ${ }^{71}$ Referimonos aqui basicamente à ideia desenvolvida no escrito de René Descartes, Discurso do Método, de 1637, de que "[...] por causa da certeza e da evidência de suas razões"72 só é verdadeiro aquilo que é calculável no sentido de uma clareza matemática; fato que determinou o método da ciência moderna de asseguramento da previsibilidade da natureza. Contrário ao pensamento de Descartes, Álvaro de Campos, no escrito “O que é a metafísica?”, publicado em 1924, no segundo volume da revista "Athena", nos adverte, em nota de pé de página:

As ciências, ao aproximarem-se do estado matemático, tornam-se mais precisas: é, porém, duvidoso que, por isso, se tornem mais certas. Tanto os puros matemáticos como os leigos em matemática tendem a atribuir a essa ciência um carácter de "certeza" que não é necessariamente exacto. A matemática é uma linguagem perfeita, mais nada. ${ }^{73}$

Campos compreende perfeitamente que a linguagem matemática é apenas uma forma exata de representar algo. Isto não significa que o exato seja o verdadeiro, aquilo que é o mais próprio da coisa. A ciência moderna, ao observar a natureza, busca apenas saber aquilo com o que pode e deve contar em seus processos. E não só isso! Como ela se baseia no princípio de que é o ser humano que assume o papel de sujeito determinante para o qual tudo o que pode ser investigado se torna um objeto, a verdade passa a ser entendida como aquilo que pode ser demonstrado de modo evidente e incontestável, assumindo, assim, um caráter de objetividade. Recuperemos este ponto em sua historicidade, ainda que de forma concisa, na medida em que o mesmo é determinante para a compreensão da passagem do sujeito (subjectum) para a representação corrente do sujeito como eu (ego), em suma, para a compreensão do homem a partir da modernidade.

A palavra geradora desta questão é hypokeímenon. Ela nasce da filosofia grega e está intimamente envolta pela questão fundamental do ser. Hypokeímenon, para os gregos, significa o substrato, aquilo que reúne tudo sobre si, refere-se à plenitude de estar assentado no mais próprio de si mesmo, em pleno vigor de si. A palavra nos fala de uma experiência essencial grega de ser no sentido de uma presença. ${ }^{74}$ Trata-se de uma presença constante, uma característica temporal, que se

\footnotetext{
${ }^{71}$ Cf. HEIDEGGER, "O tempo da imagem do mundo", in:

72 DESCARTES, Discurso do Método, p.14.

${ }^{73}$ PESSOA, Textos de Crítica e de Intervenção, p. 243; idem, Obra Completa: Álvaro de Campos, p.432.

${ }^{74}$ Cf. HEIDEGGER, A Origem da Obra de Arte, p.16. , Caminhos de Floresta, p.99-111.
} 
refere à permanência das coisas que existem. O hypokeímenon subjaz em tudo que é e há. Com Aristóteles, vamos encontrar um duplo sentido para o termo: o ontológico - "o verdadeiro ser da coisa"75 -, mas também o lógico, na medida em que significa "aquilo sobre o qual o enunciado, o lógos, enuncia" ${ }^{\text {" }}$, ou seja, algo que existe como base para o predicado. A princípio, isto não é um problema, na medida em que ambas as compreensões podem convergir. Para os gregos o ser é sempre aquilo que está presente e o lógos, o dizer originário, a confirmação deste ser. É de se fazer notar, no entanto, que o ser, na medida em que é determinado pelo dizer, torna-se o predicado através do qual algo é dito, ou seja, o hypokeímenon "é aquilo acerca do qual o predicado afirma algo."’77 Não há como negar que esta é uma compreensão que atravessou os tempos e carregou a nossa linguagem com as tintas da metafísica grega. A própria gramática buscou seus fundamentos nesta "lógica" orientada pela ideia da fala entendida como enunciado. ${ }^{78} \mathrm{O}$ entendimento do termo hypokeímenon afastou-se mesmo de sua compreensão original quando, com os romanos, o vocábulo foi traduzido por subjectum. A tradução gerou uma correspondência entre os nomes sem, contudo, trazer a experiência original da palavra grega. Inicialmente, mesmo em latim, o termo subjectum não tinha relação alguma com o sujeito no sentido de eu (ego), se referia a algo que efetivamente estava presente, àquilo que por si mesmo aí se encontrava, e o objectum, ao contrário, se referia ao que estava ausente, dado à representação, àquilo que era pensado ou imaginado. Todavia, como esta representação era algo subjetivo, imaginado e pensado pelo homem, gerou a oposição entre os termos e, ainda que houvesse uma distinção, ao final da Idade Média a confusão já estava formada. Segundo Heidegger, "aí reside a grande mudança do antigo ser para o ser medieval e para o ser atual do homem." ${ }^{\prime 79}$ É com Descartes, na obra Meditationes de Prima Philosophia, de 1641, que, na busca de um fundamentum absolutum inconcussum, de uma base absolutamente estável e firme, que o sujeito assume o papel do eu, e o eu torna-se o que está aí, o absolutamente seguro e indubitável - o ergo sum. A partir disso, o termo subjectum passa a vigorar como aquilo que se relaciona à egoidade, e o objectum é destinado somente à representação das coisas ou objetos

\footnotetext{
${ }^{75}$ HEIDEGGER, Lógica, p. 219.

${ }^{76}$ Ibidem, loc. cit.

77 Ibidem, p. 218.

${ }^{78}$ Cf. Idem, Ser e Tempo, p.229.

${ }^{79}$ Idem, Lógica, p. 220.
} 
que estão diante do sujeito, do eu que pensa e determina o objeto, ou seja, só é objeto aquilo que está diante do sujeito. Bastante inteirado desta realidade, Vicente Guedes acrescenta ao que acabamos de expor:

o homem da ciência reconhece que a única realidade para si é ele próprio, e o único mundo real o mundo como sua sensação lho dá. [...] Nada mais seu do que a sua consciência de si. Sobre essas duas realidades requinta ele a sua ciência. É muito diferente já da ciência dos antigos científicos, que, longe de buscarem as leis da sua própria personalidade [...], procuravam as leis do "exterior" e a organização daquilo a que chamavam "Natureza". ${ }^{80}$

Diferentemente dos antigos que buscavam na própria natureza as suas leis, na modernidade, é o homem, em sua subjetividade, o verdadeiro tribunal onde se decide a verdade sobre as coisas. Esta não é uma mera mudança no uso da linguagem, mas algo que traz consequências graves - trata-se de uma dominação da natureza, onde o que vale é como a natureza pode ser representada e não aquilo que ela é. O próprio Descartes, ao final do Discurso do Método, referindo-se às noções gerais sobre a Física, afirma: “[...] poderíamos empregá-las do mesmo modo em todos os usos a que são adequadas e assim nos tornarmos como que senhores e possessores da natureza." ${ }^{81} \mathrm{O}$ fato de o sujeito ser a força da representação que opera por trás da ciência, faz com que a realidade e a verdade também fiquem atreladas àquilo que é postulado por este sujeito - é ele a própria medida do real, a bitola para todo ente. Decisivo nisto é que quanto mais a ciência se singulariza em seu domínio de investigação, mais consuma a sua força instauradora, e quanto mais enraizada nisso que a singulariza como tal, mais a investigação dispõe da natureza objetivamente como objeto de uma representação. Este é um ciclo que se perpetua, pois só vale como objeto de investigação para a ciência aquilo que pode ser procurado em tal objetividade para ser representado como certeza. E mais! A ideia de um domínio da natureza empreendido pela ciência moderna acaba por cunhar uma outra espécie de homem: aparece a figura do investigador que, em busca de uma excelência científica, se move em direção à figura do técnico, do especialista. ${ }^{82}$ É somente assim que se consegue a eficácia desejada. Sobre a figura do especialista, Campos ainda diria:

Um especialista é um homem que sabe qualquer coisa de uma coisa e nada de todas as coisas. De uma coisa não se pode saber senão qualquer coisa, porque o

\footnotetext{
${ }^{80}$ PESSOA, Livro(s) do Desassossego, p.139.

${ }^{81}$ DESCARTES, Discurso do Método, p.103-104.

${ }^{82}$ Cf. HEIDEGGER, "O tempo da imagem do mundo", in: , Caminhos de Floresta, p.107.
} 
conhecimento humano é limitado. E, para perceber qualquer coisa seria preciso perceber todas as coisas, pois uma coisa é parte de todas as coisas. O especialista, pois, é um homem que não sabe nada e vive dessa ciência. ${ }^{83}$

Através dessas palavras, o poeta-engenheiro não só nos evidencia a figura do especialista como aquele que nada sabe sobre as coisas, como também o limite para o conhecimento humano. Este é o pano de fundo que move o início do sec. XX e que determina a primazia da técnica. Caminhemos um pouco mais.

\subsection{A cadência da técnica}

Diz uma antiga lenda chinesa que aquele que usa e governa sua vida segundo a medida da máquina ganha um coração-máquina, um coração subjugado à hegemonia da máquina, pulsante na cadência do domínio, do controle e do asseguramento. ${ }^{84}$ No peito que bate um coração-máquina instala-se a ganância do inalcançável, a sanha do impossível. Ávido pelo triunfo da máquina, o coraçãomáquina enche-se de cobiça e de instrumentalidade, enche-se de um fazer que promove ad infinitum uma estrutura que envolve ambos em uma dimensão concreta de pertença. O homem deixa de ser homem. Seu espírito é o da máquina.

A segunda fase poética de Álvaro de Campos é nitidamente marcada pela afinação com a tessitura temática da técnica. Referimo-nos aos ventos trazidos pelo Manifesto Futurista de Filippo Tommaso Marinetti, publicado em 20 de janeiro de 1909, no Le Figaro, cujo teor deixou rastros ímpares na estética do mundo moderno. Mais especificamente, os ventos do Manifesto Técnico da Literatura Futurista, de 1912, que por certo chegaram até o poeta. O texto das vanguardas europeias tratava, entre outras coisas, de libertar as palavras de suas exigências e apresentações convencionais, tais como versos e normas gramaticais. Rejeitando a tradição, a nova arte exaltava a beleza da máquina e celebrava a mudança e a originalidade na cultura e na sociedade. Não caberia aqui uma recuperação do modernismo e seus desvios literários ou deslocamentos traduzidos em "ismos" do movimento vanguardista, tais como o Cubismo, o Surrealismo, o Dadaísmo e o Concretismo;

\footnotetext{
83 PESSOA, Vida e Obras do Engenheiro: Álvaro de Campos, p.151.

${ }^{84}$ Referimo-nos à lenda "O puxador de água", escrita por Chuang Tzu. Cf. FOGEL, "Do coraçãomáquina - ensaio de aproximação à questão da tecnologia”, in: Da Solidão Perfeita, p.91.
} 
ou mesmo dos movimentos da própria poesia pessoana, como o Pauísmo, o Interseccionismo e o Sensacionismo, utilizados pelo poeta para introduzir o modernismo em Portugal. É notório o fato que Pessoa é considerado o mais original e o mais completo dos modernistas portugueses, não só pela singularidade de sua obra poética, mas por ela abarcar nitidamente os traços da estética modernista que rompe com a ideia cartesiana do sujeito em oposição ao objeto. Na poesia pessoana há um nexo existencial entre poeta e poesia - lugar onde vida e obra se forjam mutuamente -, e de tal forma, que a obra é ao mesmo tempo expressão de existência e gênese de realidade, como veremos mais à frente.

Voltemos a Álvaro de Campos e ao futurismo. Sabemos, através de uma carta endereçada ao "Diário de Notícias", que o poeta nega ser futurista a primeira publicação da revista Orpheu e afirma sua sintonia com o movimento muito mais pela questão temática do que pela forma. Ele diz:

A minha 'Ode Triunfal', no $1^{\circ}$ número do Orpheu é a única cousa que se aproxima do futurismo. Mas aproxima-se pelo assunto que me inspirou, não pela realização - e em arte a forma de realizar é que caracteriza e distingue as correntes e as escolas. ${ }^{85}$

No verso da carta datilografada em 4 de junho de 1915 encontra-se o rascunho de uma outra carta, endereçada a Marinetti, na qual Campos reforça, de modo bastante contundente, sua negação ao movimento futurista e esclarece o porquê de sua predileção pelo tema. No manuscrito, lemos:

Devo dizer-lhe, com toda a franqueza, que não sou de modo algum futurista; contudo, li, na sua atitude, (não na sua Obra) esse amor pelas coisas modernas que existia já em mim, e à qual procurei dar, na Ode Triumphal, a expressão puramente de engenheiro, puramente mecânica e técnica. ${ }^{86}$

Trata-se, como vemos, de uma justificativa bastante plausível, uma vez que a temática se afina com a profissão do poeta-engenheiro e por seu amor às coisas modernas. Quanto às palavras em liberdade, Campos ainda teria dito no rascunho da carta a Marinetti: "Para mim, as vossas palavras em liberdade não fazem sentido" ${ }^{87}$ Mesmo cientes que o poeta não se afina com a estética futurista e que sua relação com a máquina seja apenas uma aproximação "puramente mecânica e técnica", isso não impede aquilo que queremos expressar: a factualidade da

\footnotetext{
${ }^{85}$ PESSOA, Páginas Íntimas e de Auto-Interpretação, p.414.

${ }^{86}$ CAMPOS apud PIZARRO, "Pessoa e 'Monsieur' Marinetti”, in: Estudos Italianos em Portugal, p.81.

${ }^{87}$ Ibidem, loc. cit.
} 
presença da máquina na existência do poeta. Ouçamos o canto de um trecho de sua "Ode Triunfal", escrita em 1914, a expressar sonoramente o barulho da modernidade com sua realidade concreta e triunfo das engrenagens. Osakabe nos diz que "mais do que uma apologia do mundo contemporâneo", esta ode é "a manifestação de uma vontade de entrega do sujeito ao poder dos próprios objetos, à excelência deles. ${ }^{\prime 88}$ Com a palavra o poeta:

À dolorosa luz das grandes lâmpadas eléctricas da fábrica

Tenho febre e escrevo.

Escrevo rangendo os dentes, fera para a beleza disto,

Para a beleza disto totalmente desconhecida dos antigos.

Ó rodas, ó engrenagens, r-r-r-r-r-r-r eterno!

Forte espasmo retido dos maquinismos em fúria!

Em fúria fora e dentro de mim,

Por todos os meus nervos dissecados fora,

Por todas as papilas fora de tudo com que eu sinto!

Tenho os lábios secos, ó grandes ruídos modernos,

De vos ouvir demasiadamente de perto,

$\mathrm{E}$ arde-me a cabeça de vos querer cantar com um excesso

De expressão de todas as minhas sensações,

Com um excesso contemporâneo de vós, ó máquinas! [...]

Ah, poder exprimir-me todo como um motor se exprime!

Ser completo como uma máquina!

Poder ir na vida triunfante como um automóvel último-modelo!

Poder ao menos penetrar-me fisicamente de tudo isto,

Rasgar-me todo, abrir-me completamente, tornar-me passento

A todos os perfumes de óleos e calores e carvões

Desta flora estupenda, negra, artificial e insaciável!

Fraternidade com todas as dinâmicas!

Promíscua fúria de ser parte-agente

Do rodar férreo e cosmopolita

Dos comboios estrénuos,

Da faina transportadora-de-cargas dos navios,

Do giro lúbrico e lento dos guindastes,

Do tumulto disciplinado das fábricas,

E do quase-silêncio ciciante e monótono das correias de transmissão! [...]

Adubos, debulhadoras a vapor, progressos da agricultura!

Química agrícola, e o comércio quase uma ciência!

Ó mostruários dos caixeiros-viajantes,

Dos caixeiros-viajantes, cavaleiros-andantes da Indústria,

Prolongamentos humanos das fábricas e dos calmos escritórios! [...]

Amo-vos a todos, a tudo, como uma fera.

Amo-vos carnivoramente.

Pervertidamente e enroscando a minha vista

Em vós, ó coisas grandes, banais, úteis, inúteis,

Ó coisas todas modernas,

${ }^{88}$ OSAKABE, Fernando Pessoa: Resposta à Decadência, p.112. 
Ó minhas contemporâneas, forma atual e próxima

Do sistema imediato do Universo!

Nova Revelação metálica e dinâmica de Deus! $[\ldots]^{89}$

Não caberia aqui a reescrita de todo o poema com seus 240 versos. O trecho aqui destacado ecoa com clareza a exaltação da força e da turbulência das máquinas, reforçada pelo uso, aqui e acolá, de interjeições e onomatopeias como forma de trazer a sonoridade penetrante das rodas e engrenagens e de enaltecer a civilização mecânica. A voz do poeta-engenheiro ressoa clara - ainda que seu estado revele o ranger de dentes e a febre, os lábios secos e a cabeça a arder - a fúria das máquinas a repercutir dentro e fora do seu corpo. Sua voz reverbera o sentimento de saber-se a expressão mais pura do motor e de todos os perfumes que exalam da flora negra e artificial que é a fábrica. Notemos que há aqui a exacerbação desta última ao equipará-la a uma "flora estupenda", fato que nos permite afirmar a importância que a máquina tomou em relação à própria natureza. O próprio Campos confessa em dois momentos distintos: "A minha sensibilidade predispõe-me a sentir a máquina mais do que a árvore, a cidade mais do que o campo" e "creio na máquina porque tenho que a aceitar do mesmo modo que a árvore. ${ }^{" 90}$ A máquina, ainda que irracional, se torna o desejo do poeta na medida em que quer "ser completo como uma máquina" ou "vir na vida triunfante como um automóvel último-modelo". Campos anuncia a vontade de rasgar-se, de ser passagem aos perfumes de óleos e carvões, de poder penetrar-se e fundir-se a tudo isso e de ser parte-agente do rodar férreo, do giro dos guindastes e do barulho monótono das correias de transmissão. Fala também do caixeiro-viajante como o cavaleiro da indústria e o verdadeiro prolongamento humano da fábrica. Aqui, nos diz Osakabe: “O homem não é uma alteridade. Ao contrário, ele se harmoniza perfeitamente com este cenário de inteira materialidade." ${ }^{\prime 1}$ Sente-se tão entrelaçado às coisas modernas que este "sistema imediato do Universo" se tornou a "nova revelação metálica e dinâmica de Deus!". A técnica emerge como a nova salvação do homem, a própria personificação do

\footnotetext{
89 PESSOA, Obra Poética, p.306-308; idem, Obra Completa: Álvaro de Campos, p.48-52. A despeito da posição de Campos em relação ao futurismo, sabemos, em nota de Jerónimo Pizarro, que o poema seria dedicado a Mário de Sá Carneiro que, em carta a Pessoa, de 20 de junho de 1914, diz: "Não sei como dizer-lhe de todo o meu entusiasmo pela ode do Álvaro de Campos que ontem recebi. É uma coisa genial, das maiores em sua obra [...] você acaba de escrever a obra-prima do Futurismo." (PESSOA, Obra Completa: Álvaro de Campos, p.48).

${ }^{90}$ LOPES, Pessoa por Conhecer, p.403 e 401, respectivamente.

${ }^{91}$ OSAKABE, Fernando Pessoa: Resposta à Decadência, p.112.
} 
Deus ex machina, que surge para amarrar as pontas soltas da história da humanidade!

A ode segue até o fim no mesmo tom: enaltecendo a vida da civilização moderna dominada pela máquina, com versos que expressam sonoramente o barulho da modernidade com sua concretude e hegemonia material. Através dos versos de Campos somos remetidos de imediato à relação simbiótica entre o homem e a máquina. Vemos aqui uma inteiração completa onde nervos, olhos, lábios, ouvidos, todos os sentidos são trespassados pela fúria do progresso da modernidade que explode em rodas e engrenagens. Este é o lugar em que a cadência da vida se instala com o advento da técnica. A poética de Álvaro de Campos é a própria máquina se fazendo palavra, é quando o modo de ser que é técnica vem à fala. Ele é o poeta da técnica - é a consumação de uma estrutura em que o homem passa a ser regido por uma força de dominação que uniformiza e achata a realidade. Este é o lugar do extravio, da decadência, do coração-máquina, lugar em que o homem se desvia do seu destino. Apesar de entendermos a ciência moderna como um gatilho para a técnica e esta como uma mera aplicação daquela, é a técnica, ao contrário, a realização máxima da ciência. É a técnica a consumação e a plenificação do projeto científico, na medida em que torna o homem parte integrante neste sistema. Faz-se, pois, necessário tecermos algumas considerações sobre a questão da técnica e sua relação com o homem. Busquemos a raiz dessa questão.

O termo técnica deriva do grego téchnikon e designa o que pertence à téchnē, o "conhecer-se no ato de produzir." 92 Isto significa dizer que, na experiência grega, o produzir e o fazer não estavam atrelados à manipulação, à fabricação, mas ao terreno do conhecer, lugar em que aquilo que aparece é aquilo que está aí posto a nossa frente. Lembremos do verbo alemão vorstellen, tão utilizado por Heidegger, que, formado pela preposição vor (na frente de, diante de) e pelo o verbo stellen (colocar, pôr, fazer levantar), significa colocar na frente, apresentar. ${ }^{93}$ Téchnē estava, pois, relacionada ao saber fazer no sentido do tornar manifesto. Na aurora grega, há um nexo entre o saber e o fazer. Épistème e téchnē se relacionavam tão naturalmente que, muitas vezes, entendia-se uma pela outra: a primeira, como uma forma de entendimento com alguma coisa, e a segunda, como identificação do fazer

\footnotetext{
${ }^{92}$ HEIDEGGER, Língua de Tradição e Língua Técnica, p.21.
}

${ }^{93}$ KELLER, Michaelis, p.325, p.283 e p.327, respectivamente. 
com a própria coisa. Ambas estavam ligadas ao sentido mais amplo do conhecimento; um saber que fornece, a partir de si próprio, elementos de compreensão e elaboração da sua própria ciência. $\mathrm{O}$ fato de épistème e téchnē terem esse parentesco não era um problema, pois ambos os saberes buscavam trazer algo à luz em sua essência. Isto significa que há nisso uma relação direta entre o saber e o fazer na sua força geradora. Conhecimento e criação estavam relacionados aos entes em sua totalidade, buscavam a coisa na perspectiva de sua essência, colocando-se diante dela de forma que a própria coisa se mostrasse em seu modo de ser. Nem a épistème e nem a téchnē diziam respeito a um modo de compreensão de realidade que tinha por objetivo a finalização de um produto, designavam o fazer em seu sentido mais elevado, deixando a coisa vir à presença por si mesma, como uma forma de romper no aberto da sua própria natureza. ${ }^{94}$ Lembremos que natureza, em latim, se diz nātūra, que, em sua etimologia, é formada por nāscor ou gnāscor que significa nascer, trazer ao mundo. Como forma derivada, temos nātus e nātūrus, cujo sufixo -urus, também presente em orìtur e derivado de orior, significa saltar, brotar, nascer, derivar sua origem; surgir, gerar, a força que gera.${ }^{95}$ Tudo isso, para dizer que aquilo que se mostrava era sempre nascimento, gênese. Assim era a phýsis grega - pura eclosão e emergir abrupto da coisa desde si mesma, um modo todo próprio de ser e aparecer.

Alberto Caeiro - mestre de Campos, de Reis e do próprio Pessoa, é o poeta da phýsis, é o criador da poesia da natureza. O poeta sente-se tão próximo à natureza que afirma ser ele "um intérprete da Natureza", "o único poeta da Natureza” e, até mesmo, "o Descobridor da Natureza". ${ }^{96}$ Ainda não nos deteremos na relação de Caeiro com as coisas nesta etapa do caminho. Entretanto, não poderíamos deixar de fazer menção ao fato de que é com o poeta da natureza que vemos o desabrochar das coisas em si mesmas. É Caeiro que afirma: “Todo o repouso da natureza está comigo. ${ }^{" 97} \mathrm{O}$ poeta se sente tão integrado à natureza que, mesmo na morte, reafirma esta união com seus elementos. Ouçamos os versos, escritos em 1915:

Quando a erva crescer em cima da minha sepultura, Seja esse o sinal para me esquecerem de todo.

94 Cf. HEIDEGGER, Heráclito, p.213-216.

95 ERNOUT; MEILLET, Dictionnaire Etymologique de la Langue Latine, p.429-430 e 468, respectivamente.

${ }^{96}$ PESSOA, Obra Poética, p.220, p.237 e p.226, respectivamente.

97 PESSOA, Poemas Completos de Alberto Caeiro, p.39. 
A Natureza nunca se recorda, e por isso é bela.

E se tiverem a necessidade doentia de "interpretar" a erva verde sobre a minha sepultura,

Digam que eu continuo a verdecer e a ser natural. ${ }^{98}$

Vemos que o poeta se põe de forma tão unívoca e uníssona com a natureza que nem mesmo a morte pode impedi-lo de "verdecer" e ser natural. Isto significa o mesmo que dizer que a morte é um estado tão natural quanto a vida. A única coisa que não interessa a Caeiro é a recordação, pois esta é uma traição à natureza, uma vez que a lembrança do que era simplesmente não é mais. A recordação não expressa a experiência vivida, ela é apenas uma representação desta vivência. A beleza está exatamente no modo de ser que é o desabrochar da natureza desde si mesma e em si mesma. Isto é phýsis! Voltemos à materialidade e concretude dos fatos. Retomaremos este caminho mais adiante.

O problema surge quando a ciência emergente da era moderna, cuja força geradora se funda na técnica, em nada se aproxima da épistème da origem que, junto à téchnē, via a coisa a partir da própria coisa. A ciência grega nunca foi exata, não havia esta demanda. O próprio télos grego não deve ser entendido como meta ou finalidade, mas, sim, como levar a essência de algo a sua consumação, plenitude e esplendor. A técnica moderna desconhece completamente isto! Ela é a soma de aptidões que pertencem exclusivamente ao homem e que possibilitam a utilização da natureza para fins humanos. Trata-se simplesmente de um meio para um fim, e uma definição instrumental não pode ser instauração de gênese. O desencobrimento dominante, o modo de realidade se fazendo realidade que rege a técnica moderna é o de exploração e cumulação da ação enquanto operatividade do homem sobre a natureza. Na realidade, trata-se de promover o máximo rendimento possível com um mínimo de esforço. Ortega y Gasset, em preleções posteriormente publicadas com o título Meditação da Técnica, entende que um dos traços mais evidentes da técnica moderna é o fato de que ela, na medida em que traz segurança e controle, é um esforço para poupar esforço. Gasset nos fala que a técnica é a reforma da natureza realizada através de atos técnicos que

“[...] não são aqueles em que fazemos esforços para satisfazer diretamente nossas necessidades, sejam estas elementares ou francamente supérfluas, mas aqueles em que dedicamos o esforço, primeiro, para inventar e, depois, para executar um plano

\footnotetext{
${ }^{98}$ PESSOA, Obra Poética, p.238; idem, Obra Completa de Alberto Caeiro, p.93.
} 
de atividades $[\ldots] .{ }^{999}$

As palavras do pensador espanhol revelam uma característica fundamental: o caráter de dominação ilimitado da técnica e sua simbiose com o homem. Uma dominação de tal forma, que nos faz pensar numa codependência instaurada no processo do conhecimento. Em outras palavras, a técnica impõe à ciência da natureza uma captação e transformação de sua própria energia que se intensifica gerando, em última instância, o saber sobre algo na forma de um domínio. Esse caráter ilimitado de dominação se expande em relação ao próprio homem, que se vê intimado a provocar a natureza a fornecer a sua energia na forma previamente elucubrada. ${ }^{100}$ Isto significa que na técnica moderna primeiro cria-se um plano para, em seguida, executá-lo. Tal compreensão deve ser aprofundada à luz de uma frase de Heidegger que diz: "a ciência é a teoria do real." ${ }_{101}$ Incide sobre ela a ideia de que o que vem à luz - o real - é uma teoria elaborada pela ciência moderna que tem por trás o homem. Trata-se de algo engendrado pelo homem e que se alicerça sobre uma construção prévia que se assenta em métodos, os quais têm como resultado um real pré-fabricado, ou seja, aquilo que emerge não é aquilo que por si mesmo desabrocha. Na técnica moderna, a natureza é submetida e subjugada a um processo de absoluto controle dado pela subjetividade operante que a manipula objetivadamente. Assim, mais do que ser apenas um meio para satisfazer as necessidades do homem, promove-se uma verdadeira reforma da natureza realizada através de atos técnicos, os quais visam assegurar a satisfação de resultados. ${ }^{102}$ Isto é muito grave! A técnica acaba por ser um sistema que dispõe de informações que descartam por completo a coisa em sua gênese. O que interessa é apenas o seu índice informativo. Teorizar é, pois, estabelecer relações de informação, índices de controle, e pouco interessa o sentido ontológico ou sua experiência. Isto é o nivelamento e o achatamento completo da terra! O que interessa, em última instância, é o controle: um mecanismo que funcione como asseguramento sobre alguma coisa. Por consequência, assim também será a realidade: o objeto de uma representação. Algo que nos fez afirmar que não há uma realidade concreta, mas apenas teorias postuladas pelo sujeito que constroem a realidade. Isto em nada tem

\footnotetext{
${ }^{99}$ ORTEGA Y GASSET, Meditação da Técnica, p.30.

${ }^{100}$ Cf. HEIDEGGER, Língua de Tradição e Língua Técnica, p.29.

${ }^{101}$ HEIDEGGER, "Ciência e pensamento de sentido", in:

${ }^{102}$ Cf. Ibidem, loc. cit. , Ensaios e Conferências, p.40.
} 
a ver com a ideia de teoria elaborada na Grécia que, de alguma forma, possuía uma significação mais nobre. Na origem grega, o substantivo theōría provinha do verbo theōrein que, por sua vez, nasceu de dois outros termos: théa, que quer dizer fisionomia, o perfil de algo e como ele se mostra, como em théatron, o lugar em que se vê e theáomai, a visão que se oferece. Platão cunhou o termo eîdos para falar desse perfil em que o vigente mostra o que ele é. O outro termo derivativo é horáō, que significa ver e tomar algo sob os olhos; na forma figurada, ver com a mente, compreender. ${ }^{103}$ Isto significa que, na aurora grega, teoria era ver a coisa no vigorar de sua mostração plena e, nesta visão, ser com ela. ${ }^{104}$ Isto é conhecer, é conascer, a visão em sua forma mais requintada e o pensamento em sua forma mais elevada.

No modo de ser que é o da tecnologia virá à tona uma com-posição, a saber, o arranjo de toda a realidade compreendida objetivadamente como fonte de energia, com a simples finalidade de estocá-la como um depósito sempre disponível para uso. Heidegger, no curso de 1953, intitulado “A questão da técnica”, chega a cunhar um termo para esta com-posição: Ge-stell. Lembremos que o prefixo Ge- diz reunião, com; e -stell, pôr, colocar. A com-posição é a força de reunião daquilo que está posto e que compele o homem a desencobrir o real como dis-ponibilidade. ${ }^{105} \mathrm{E}$ não só isto! Há nesta palavra toda uma armação, uma estrutura, uma esquematização para ajustar as coisas de modo a que tudo vire recurso, insumo, matéria-prima. As coisas assumem o seu caráter de utilidade. A própria realidade está impregnada pela ideia de utilidade. "Os entes e os objetos que constituem o mundo", diz Octavio Paz, "tornaram-se para nós coisas úteis, não usáveis ou nocivas. Nada escapa a esta ideia do mundo como um vasto utensílio: nem a natureza, nem os homens, [...] todos somos instrumentos." ${ }_{106}$ Isto nada mais é do que um chamado explorador que tem como essência, como força geradora, o desencobrir do real de forma a que este seja apenas um fundo de reserva disponível ou descartável. Este é o modo como se vê toda a realidade. A visão do homem está contaminada. Paz continua:

\footnotetext{
${ }^{103}$ LIDDELL; SCOTT, A Greek-English Lexicon, p.796-797 e 1244, respectivamente.

${ }^{104}$ Cf. HEIDEGGER, "Ciência e pensamento de sentido", in: ___, Ensaios e Conferências, p.45.

${ }^{105}$ Cf. HEIDEGGER, “A questão da técnica”, in:

${ }^{106}$ PAZ, A Busca do Presente, p.46. , Ensaios e Conferências, p.23.
} 
Nunca é possível ver o objeto em si; ele está sempre iluminado pelo olho que o vê, está sempre moldado pela mão que o acaricia, oprime-o ou o empunha. $\mathrm{O}$ objeto, instalado em sua realidade irrisória como um rei em um vulcão, logo muda de forma e se transforma em outra coisa. O olho que o vê o torna maleável como cera; a mão que o toca o modela como argila. O objeto se subjetiva. [...] Evidentemente, trata-se dos mesmos olhos, só que servindo a poderes distintos. E, assim, se inicia uma vasta transformação da realidade. ${ }^{107}$

É clara a crítica de Paz. Tudo se transforma em outra coisa. Hoje, quando se vê um rio, não se vê o rio, se vê aquilo que o rio tem como propriedade para a fabricação de bens, o que nele tem de mão de obra, o que nele tem de lucro, e, nesse emaranhado de fios, o que está sempre enredado é a estrutura da com-posição. Vêse tudo isso, menos o rio. Lembremo-nos dos versos de Alberto Caeiro a cantar o rio de sua aldeia, em 1914:

O Tejo é mais belo que o rio que corre pela minha aldeia, Mas o Tejo não é mais belo que o rio que corre pela minha aldeia Porque o Tejo não é o rio que corre pela minha aldeia,

O Tejo tem grandes navios

E navega nele ainda, Para aqueles que veem em tudo o que lá não está, A memória das naus.

O Tejo desce de Espanha E o Tejo entra no mar em Portugal. Toda a gente sabe isso.

Mas poucos sabem qual é o rio da minha aldeia E para onde ele vai E donde ele vem. E por isso, porque pertence a menos gente, É mais livre e maior o rio da minha aldeia.

Pelo Tejo vai-se para o Mundo. Para além do Tejo há a América $\mathrm{E}$ a fortuna daqueles que a encontram.

Ninguém nunca pensou no que há para além Do rio da minha aldeia.

O rio da minha aldeia não faz pensar em nada Quem está ao pé dele está só ao pé dele. ${ }^{108}$

Os versos nos colocam diante do Tejo, exaltam sua grandeza e glória. Entretanto, quando se está junto ao Tejo nunca se está junto ao Tejo, o rio remete para muitas outras coisas - o rio é memória dos grandes feitos, é símbolo, envia para outra coisa que não o rio. $\mathrm{O}$ Tejo nos aponta para a grandiosidade dos momentos históricos

107 PAZ, A Busca do Presente, p.47.

108 PESSOA, Obra Poética, p.215-216; idem, Obra Completa de Alberto Caeiro, p.53. 
portugueses, nos reporta para o além-mar, para as grandes navegações e conquistas, para as grandes fortunas que as naus portuguesas trouxeram através de suas águas. O coração-máquina que vê o Tejo vê as muitas águas do rio e se extravia daquilo que o rio é. Ao falar do rio de sua aldeia, Caeiro também se coloca diante do rio, mas de outra forma. Não quer saber de sua extensão, de onde vem ou para onde vai. Não quer saber de seus feitos ou de suas conquistas. Nada quer do rio. O rio também nada quer. Ao se colocar ao lado do rio, o poeta simplesmente vê o rio como o rio de sua aldeia. Não há nada a pensar. Isto é pura presença, é vida - o simples destino de seguir de nada e para nada. Isto é nascividade, é seguir a natureza, é co-nascer com ela, é estar em casa. O rio se revela para Caeiro como aquilo que ele é, nem mais, nem menos. Há nisto um caráter de saciedade, de ser alegre com pouco, que é absolutamente extraordinário!

Oswald Spengler, no livro O Homem e a Técnica, faz uma crítica bastante ácida ao homem da técnica. Para ele, o homo technicus possui uma

alma (que) avança cada vez mais, num sempre crescente alheamento da natureza. [...] O Homem arrebatou à Natureza o privilégio da criação [...] se libertou dos laços da Natureza e com cada criação nova se afasta cada vez mais dela, torna-se cada vez mais seu inimigo. ${ }^{109}$

Isto significa que a natureza é descartada e encarada apenas como um eficaz sistema operacional de forças previamente manipulado de modo a confirmar a condição pré-estabelecida pela teoria, como num arquivo de regras e normatização; uma fórmula totalmente artificial do projeto antecipatório científico. Isso é o lógos moderno, o sentido contemporâneo, o modo como tudo aparece previamente, por antecipação. Alberto Caeiro também chega a questionar o método e a normatização, em 1914:

Tristes das almas humanas, que põem tudo em ordem,

Que traçam linhas de coisa a coisa,

Que põem letreiros com nomes nas árvores absolutamente reais,

E desenham paralelos de latitude e longitude

Sobre a própria terra inocente e mais verde e florida do que isso! ${ }^{110}$

A própria verdade da ciência também será colocada em xeque, em 1918:

Todas as opiniões que há sobre a Natureza

Nunca fizeram crescer uma erva ou nascer uma flor.

Toda a sabedoria a respeito das coisas

${ }^{109}$ SPENGLER, O Homem e a Técnica, p.68-69.

${ }^{110}$ PESSOA, Obra Poética, p.225; idem, Obra Completa de Alberto Caeiro, p.69. 
Nunca foi coisa em que pudesse pegar, como nas coisas;

Se a ciência quer ser verdadeira,

Que ciência mais verdadeira que a das coisas sem ciência?

Fecho os olhos e a terra dura sobre que me deito

Tem uma realidade tão real que até as minhas costas a sentem.

Não preciso de raciocínio onde tenho espáduas. ${ }^{111}$

Isto significa que, para o poeta, aquilo que rege a ciência é algo que está fora da natureza. Para ele, o real e o verdadeiro não precisam de raciocínio. O saber que se adquire através da ciência é algo puramente artificial, da ordem de uma produção técnica. O que impera é o espírito calculador, o qual não deixa espaço para a liberdade, para o desabrochar da coisa por si mesma e, nem sequer, para o inesperado, para a possibilidade de algo chegar até o homem. Lembremos de Heráclito que, no fragmento 18, diz: "Se não se espera não se encontra o inesperado, sendo sem caminho de encontro nem vias de acesso." 112 Há que se esperar o inesperado! Ouvimos do pensador: não há acesso. A técnica moderna simplesmente apodera-se da téchnē como um modo de produção, dela se apropria e insaciavelmente a conduz ao inatingível, ao inalcançável, ao infinito. Este é um envio que é um desvio. Logo nos vem a pergunta: por que o destinar da técnica se manifesta como um desvio? E quais consequências isto traz para o homem? Recuperemos para avançar.

Como vimos, na origem grega, a téchnē era um movimento de promoção de gênese e geração da phýsis. O fazer do homem estava de tal maneira sintonizado com este movimento, que ele participava desta produção, mas ele não se entendia como o autor. Em contrapartida, o homem da técnica já aparece como o criador, um eu constituído que, por sua vez, é constituinte, produtor, organizador, anunciador e programador do real. A natureza acaba por ser apenas uma posição e objetivação desse sujeito. Trata-se, como vimos, de uma realidade regida por uma exploração que impõe à natureza um modo de ser que nada tem a ver com a phýsis grega. $\mathrm{Na}$ modernidade, a natureza é apenas um grande armazém e a técnica é o modo como a ciência moderna se evidência no seu projeto. Não nos reportamos aqui a uma experiência, mas, sim, a um experimento. O experimento é a antecipação e a programação da experiência. Como vimos, elabora-se uma teoria que nada mais é do que uma hipótese, uma pressuposição que será testada até o ponto em que se

111 PESSOA, Obra Poética, p.242-243; idem, Obra Completa de Alberto Caeiro, p.103.

112 HERÁCLITO, Frag.18, in:__, Os Pensadores Originários: Anaximandro, Parmênides, Heráclito, p.63. 
tenha o controle sobre aquele fenômeno. Enquanto isto não acontece, volta-se ao experimento. Quando se consegue o resultado esperado, o experimento torna-se verdadeiro e real. Nesta história toda, o que menos interessa é conhecer ou saber na compreensão que havíamos falado, que é o de ver ou participar de uma coisa no seu sentido ontológico, no seu sentido de ser. Isso não interessa! O que interessa é o querer científico e a necessidade de controle e esquematização. Kant, na introdução à Crítica da Razão Pura, referindo-se à forma como Galileu e Torricelli interrogam a natureza, diz que:

Eles compreenderam que a razão só entende aquilo que ela mesma produz segundo seu projeto; e que ela tem que colocar-se à frente com os princípios de seus juízos segundo leis constantes, e forçar a natureza a responder às suas perguntas em vez de se deixar conduzir por ela [...]. ${ }^{113}$

Isto significa que o que passa a valer não é a verdade, mas a função de controle que ela ocupa. A verdade passa a ser subentendida como parâmetro e grau de certeza e segurança. Trata-se, como acabamos de ver, de uma antecipação planejada do experimento que precisa se ajustar e adequar ao esquema proposto pela ciência. Isto é uma exploração desafiadora, pois é o homem da técnica que - movido por mecanismos de extração, transformação, estoque, distribuição, reprocessamento, e sabe-se lá mais o quê! - conduz a pergunta ao seu bel prazer. Decisivo nisso é que é o homem que promove esta exploração. Ruminando por trás, está a vontade humana regida pela autonomia do eu que retroalimenta e intensifica o movimento de certeza do controle e, com isso, ocorre uma modificação na própria essência do homem, que perde o limite e se move ao infinito - quer controlar o controle e assegurar o asseguramento. A sanha do infinito é algo que também ressoa nos versos de 1916, de Álvaro de Campos. Ele diz:

[...] Sou um monte confuso de forças cheias de infinito

Tendendo em todas as direcções para todos os lados do espaço,

[...] Sou uma grande máquina movida por grandes correias

De que só vejo a parte que pega nos meus tambores,

O resto vai para além dos astros, passa para além dos sóis,

E nunca parece chegar ao tambor donde parte...

Meu corpo é um centro dum volante estupendo e infinito

Em marcha sempre vertiginosamente em torno de si,

[...] Dentro de mim estão presos e atados ao chão

Todos os movimentos que compõe o universo.

${ }^{113}$ KANT, Crítica da Razão Pura, B XIII, p.28. 
A fúria minuciosa e dos átomos.

A fúria de todas as chamas, a raiva de todos os ventos,

A espuma furiosa de todos os rios, que se precipitam, $[\ldots]^{114}$

Os versos nos falam dos excessos de uma engrenagem que roda eternamente em busca do infinito; de um lugar em que a vida é atravessada violentamente pela força da sanha de um fazer, de um produzir que não para, que não se contenta com o possível e quer mais, sempre mais. A exacerbação dessas forças, ainda que confusas, denotam a cumulação da vontade que se move em todas as direções. Trata-se de forças que estão plenas do ilimitado, forças que tudo querem. Não há uma contenção ou uma medida, mas, apenas o excesso, a pretensão de ver seu corpo como uma "grande máquina movida por grandes correias", as quais se movem para além dos astros e dos sóis. Ele é o próprio universo, a fúria dos ventos e dos rios. Não há um limite. O poeta fala de um querer que quer o que não pode ter. $\mathrm{A}$ consumação de uma essência é a plenificação de algo. No caso da técnica, é a plenificação da hýbris, do exagero, do descomedimento. A terra passa a ser um grande almoxarifado e o homem o dono dessa chave. Lembremos que, no mito, Ícaro é a personificação da hýbris, é o símbolo da volúpia e da megalomania. Mesmo admoestado pelo pai que lhe pedia para que guardasse a medida entre as ondas do mar e os raios de sol, ele ultrapassa o metrón, a medida do possível, e, voando além, destrói-se. A hýbris é, pois, a ultrapassagem da medida, é a desmesura através da qual o homem se esquece de que é um simples mortal. Lembremos também que, no mito de Hesíodo, a medida do homem é dada pelo "ser". O homem é dimensionado pelo trabalho e pela justeza de suas medidas. Em Hesíodo, o ánthropos, é homo, húmus, o barro, a argila, aquele que descende de Epimeteu e Pandora, que precisa ganhar a vida com o suor do seu rosto e que, por isto, está completamente integrado ao ser da sua medida. ${ }^{115}$ Esta pequena digressão ao mundo do mito nos faz entender o desvio que a técnica impõe ao homem, o quanto ela o afasta do seu modo próprio de ser. Como mestre e senhor da natureza, o homem da técnica é o onipotente, aquele que tudo sabe e tudo pode - o próprio deus. Trata-se da exacerbação máxima da autonomia da subjetividade, do sujeito que quer organizar e planificar tudo de acordo com esse querer que tudo quer. O problema é o homem se colocar como destino de tornar-se aquilo que ele não pode ser - o

\footnotetext{
${ }_{114}$ PESSOA, Obra Poética, p.408; idem, Obra Completa: Álvaro de Campos, p.166-167.

115 BRANDÃ̃, Mitologia Grega, v.1, p.165.
} 
senhor da terra e da realidade. Isto é volúpia! É um excesso que se põe como um valor supremo, mas que também se mostra como uma impossibilidade, pois querer o impossível não pode ser a meta do homem. A essência da técnica é uma armação que, de modo dissimulado e perverso, deixa o homem a serviço e à mercê desta com-posição. O niilismo aparece como a reverberação deste fundo vital existencial que envolve, se apropria e se apodera do homem, lugar em que impera a sanha, a vontade do infinito e do ilimitado. Isto significa que a técnica não somente envolve a mutação da natureza, mas, sobretudo, a mutação da essência do próprio homem. O domínio total da realidade armado pela estrutura da disponibilidade compromete a própria existência humana. A técnica moderna, velada e silenciosamente, encaminha o homem para um grande deserto, para a derrocada completa do poder do espírito e, como bradava Nietzsche, em Assim falou Zaratustra: "Ai daquele que abriga desertos!"116 Álvaro de Campos, em 1930, sua terceira fase poética, também canta a desertificação do homem:

Grandes são os desertos, e tudo é deserto.

Não são algumas toneladas de pedras ou tijolos ao alto

Que disfarçam o solo, o tal solo que é tudo.

Grandes são os desertos e as almas desertas e grandes -

Desertas porque não passa por elas senão elas mesmas, Grandes porque de ali se vê tudo, e tudo morreu.

Grandes são os desertos, minha alma!

Grandes são os desertos. [...]

Grandes são os desertos, e tudo é deserto.

Grande é a vida, e não vale a pena haver vida $[\ldots]^{117}$

O poeta fala da aridez interior. O solo da alma está deserto e nada pode pavimentar este solo. Nada pode disfarçar o deserto. Não há religião. Não há ciência. Não há saída. A própria vida não tem sentido. Tudo morreu. A tendência do mundo moderno de se uniformizar e unidimensionalizar, diante desta realidade acachapante, não deixa nenhuma outra possibilidade de ser. Herbert Marcuse, no escrito $O$ Homem Unidimensional, entende que quanto mais racional e técnica é a sociedade, mais inconcebível se torna a possibilidade de o homem "[...] quebrar sua servidão e tomar sua libertação em suas próprias mãos." 118 Isto significa que não só o homem é submetido a uma subserviência vital, mas, sobretudo, que não há como

\footnotetext{
${ }^{116}$ NIETZSCHE, Assim falou Zaratustra, p. 294.

${ }_{117}$ PESSOA, Obra Poética, p.382-383; idem, Obra Completa: Álvaro de Campos, p.259.

118 MARCUSE, O Homem Unidimensional, p.45.
} 
se livrar desse jugo. O filósofo alemão chega mesmo a afirmar que estamos diante de um quadro grave de irracionalidade, onde o corpo e o espírito são apenas extensões do mundo objetivo. E pior! Grande parte da humanidade não vê que é instrumento de uma dominação, não tem consciência de que vive sob um controle silencioso que impede a possibilidade de novas formas de existência. Trata-se de um sistema altamente sofisticado que não permite ao homem reconhecer que essa estrutura só se reconhece no todo. A individualidade se perde. $\mathrm{O}$ homem alienado é massacrado por uma existência alienada. Resta apenas um padrão de comportamento unidimensional e uniformizado de viver. Qualquer pensamento fora disso é totalmente repelido pela "irracionalidade" vigente. Isto é o deserto! Isto é o desvio!

Dócil ao espírito da máquina, o homem acaba por ter uma existência domesticada e em uníssona sintonia com a técnica. Coelho Pacheco ${ }^{119}$ escreve, por volta de 1917:

[...] O meu pensamento muitas vezes trabalha silenciosamente

Com a mesma doçura duma máquina untada que se move sem fazer barulho

Sinto-me bem quando ela assim vai e ponho-me imóvel

Para não desmanchar o equilíbrio que me faz tê-lo desse modo

Pressinto que é nesses momentos que o meu pensamento é claro

Mas eu não o oiço e silencioso ele trabalha sempre de mansinho

Como uma máquina untada movida por uma correia

E não posso ouvir senão o deslizar sereno das peças que trabalham $[\ldots]^{120}$

Vemos aqui uma relação inteiramente apaziguada com a máquina, bem diferente daquela de Álvaro de Campos, cujos versos citamos no início desta parte de nosso escrito. Pacheco já não expressa a fúria do poeta-engenheiro, mas, uma serenidade ao falar do pensamento que trabalha silenciosamente como uma máquina. $\mathrm{O}$ fato de assim o ser, denota uma relação equânime e tranquila, uma vez que é "nesses

\footnotetext{
119 Coelho Pacheco foi, durante muito tempo, considerado um pseudônimo de Fernando Pessoa. O poema acima citado, intitulado "Para além doutro oceano", chegou a ser enviado para a revista Orpheu, mas não chegou a ser publicado. Foi publicado pela primeira vez numa edição da revista Inquérito, em 1953, com um prefácio de Adolfo Casais Monteiro, que alegava se tratar de um poema inédito de Fernando Pessoa. O mesmo poema chega a constar na Obra Poética, a qual vimos trabalhando. Todavia, sabemos, através de um artigo publicado por Teresa Rita Lopes, no $J L-$ Jornal de Letras, Arte e Ideias (no.1058, de 20 abril a 3 de maio de 2011), intitulado "O seu a seu dono", que José Coelho Pacheco é contemporâneo de Pessoa e autor do poema citado, fato que resgatou a autoria do poema e pôs fim ao erro que durou inúmeras décadas. Cf. [online] https://revistalusofonia.wordpress.com/2011/09/06/o-seu-a-seu-dono-pessoa-"desapossado"-decoelho-pacheco/. Acesso em: 15 de maio de 2018. Ainda que o poema tenha sido atribuído a outro autor, achamos por bem citá-lo, uma vez que o mesmo orbita em torno de nossa temática e consta no livro de Pessoa.

${ }^{120}$ PESSOA, Obra Poética, p.426.
} 
momentos que o pensamento é claro"! Comparar o pensamento a uma máquina é de todo estar em uma relação harmônica, em uma equivalente correspondência, em uma adequada conformidade, ou seja, homem e máquina articulados, apropriados e apoderados por uma estrutura. A técnica já não se reduz a uma atividade do homem, ela como tal já é o alcançar e o realizar de um projeto a serviço do qual o homem também está. Todo este estado de coisas conduz a um processo de desumanização do homem - ele é a máquina que move a máquina. Este é o nível mais superficial da existência humana. Isto é o grande perigo! O problema é o homem não se dar mais conta de que isto é perigo e o perigo não se mostrar mais como tal. A situação assim consolidada acaba por determinar uma indiferença, uma apatia, uma letargia, uma anestesia completa, o próprio tédio.

\subsection{O tom da técnica}

O tédio é o páthos do início do sec. XX. O tédio é a tonalidade que entoa, que dá o tom do tempo da noite do mundo. O tédio é a entonação do fracasso e decadência da ordenação moral do mundo e da crença nas categorias da razão, fomentada pela ingênua convicção de ser o homem a medida para o critério de valoração das coisas, o único capaz de buscar um sentido que não há e que está fora de qualquer possibilidade de ser. Referimo-nos aqui à impossibilidade de ser das categorias metafísicas de fundamento, verdade, totalidade, tais como pensadas pela tradição. $\mathrm{O}$ fracasso desses valores acrescido à aridez do mundo, faz irromper o tédio - uma disposição de humor que dilacera o homem e se caracteriza pelo desencanto, pela falta de ânimo, pelo desassossego. Dentre as tonalidades afetivas, o tédio é, sem dúvida, uma das fronteiras a ser investigada. Entretanto, não nos demoraremos nesta temática, elencamos a angústia, que será aprofundada no próximo capítulo. Faremos parada apenas brevemente, à guisa de identificar um fenômeno tão recorrente neste momento do mundo. O que é, então, o fenômeno do tédio? De modo a introduzir o tema, ouçamos os versos de Álvaro de Campos:

$\mathrm{Ah}$, as horas indecisas em que a minha vida parece ter sido de um outro... 
As horas do crepúsculo no terraço dos cafés cosmopolitas!

$\mathrm{Na}$ hora de olhos húmidos em que se acendem as luzes

E o cansaço sabe vagamente a uma febre passada. ${ }^{121}$

O poeta retrata um estado de espírito totalmente atravessado pelo tédio. Fala de um fenômeno que demarca a relação do homem com o tempo, das horas paradas demarcando uma existência que não é sentida, pois a vida cheia de vida no terraço dos cafés cosmopolitas parece de outro. O fim da tarde, o fim do dia, cadencia o tempo perdido das horas indecisas a aguardar a luz que acende, o que não vem, o que não pode ser. $\mathrm{O}$ que resta são as horas que não passam e arrastam o tempo com um peso insuportável, o que resta é o deserto da monotonia do dia. O tédio se instala no exato momento em que a dimensão do tempo se torna extremamente longa para o homem. Nesse processo de infinita espera, há uma saturação, um cansaço, um "em vão". Aquilo que era cobiça e sanha se torna indiferença e inércia, cansaço e lassidão. O que outrora insaciavelmente alimentava o homem de sanha e volúpia é tomado pelo desânimo, se esvai no vazio do tempo. $\mathrm{O}$ que o dia buscava, morre ao acender das luzes do fim do dia. A passagem do tempo é aqui delineada de modo a ressaltar a paralisia, a monotonia vazia. Falta força, ânimo, sentido de vida.

São muitas as formas como o tédio se manifesta. Nas preleções dos anos de 1929 e 1930, publicadas com o título Os Conceitos Fundamentais da Metafisica: Mundo - Finitude - Solidão, Heidegger nos apresenta e descreve três possibilidades para o fenômeno: a primeira, uma forma mais superficial do tédio que se caracteriza por "ser entediado por alguma coisa", neste caso, aquilo que nos entedia vem de fora; na segunda, uma forma intermediária do tédio, vamos nos deparar com "o entediar-se junto a algo", aqui, não se trata do entediar-se com algo, mas "junto a algo", ou seja, o tédio já se encontra instalado e a situação em que o entediado se encontra não tem grande importância; a terceira forma e que mais reverbera nos poemas de Pessoa, Álvaro de Campos e Bernardo Soares, se volta para o tédio profundo. Referimo-nos ao estar sem-chão, ao pairar em meio ao vazio entediante, à tonalidade afetiva fundamental capaz de uma abertura de mundo propriamente possibilitadora de uma afinação do homem com o seu modo de ser mais próprio. Neste caso, o tédio não está ligado a uma situação determinada ou a alguma coisa em particular, mas, à temporalidade enquanto tal - o tempo torna-se longo de tal

${ }^{121}$ PESSOA, Álvaro de Campos: Livro de Versos, p.39. 
forma que, nesta demora, abre-se uma indeterminação oprimente e jamais determinável, um solo totalmente esgarçado a manter o homem preso e banido de qualquer ação. Trata-se de uma paralisia que, no caso do poeta, ao bani-lo do horizonte temporal, faz com que ele seja lançado ao elemento possibilitador de sua existência mais própria: a criação. Heidegger nos lembra que: "toda ação criadora está encerrada no ânimo pesado da melancolia." 122 Caminhemos um pouco mais dentre os poemas, de modo a delinear o tédio, a monotonia das horas, o vazio de ser. Em 1914, Pessoa descreve o tédio a partir de um silêncio. Ele diz:

[...] Dentro em mim cai silêncio em flocos.

Parou o cavaleiro à porta...

E o frio, e o gelo em brancos blocos

Mancha de hirto a noite morta...

Meus tédios desiguais, sufoco-os,

A minha alma jaz ela e absorta. ${ }^{123}$

O silêncio, a ausência de som, toma o poeta. Isto que chega e o paralisa é frio, morto. São muitos os tédios a asfixiar sua existência. São muitos os tédios que permanecem à espreita, que chegam sem nenhum convite, na soleira da porta $\mathrm{e}$ anunciam que o tédio que bate é gélido. O frio é algo que também fala da apatia, do desânimo, da indiferença, da inércia - todos são modos do tédio, do cansaço existencial. Quatorze anos mais tarde, em 1928, o poeta volta a tematizar o tédio comparando-o a uma luz azulada e fria. Ouçamos:

É inda quente o fim do dia...

Meu coração tem tédio e nada...

Da vida sobe maresia...

Uma luz azulada e fria

Pára nas pedras da calçada...

Uma luz azulada e vaga

Um resto anónimo do dia...

Meu coração não se embriaga

Vejo como que em si o dia...

É uma luz azulada e fria. ${ }^{124}$

Os versos reforçam a ideia do cair da noite que traz a luz azulada e fria a reluzir o torpor, o prenúncio do tédio, a paralisia que se espalha sobre a vida como a maresia que vem do mar - algo vago, impreciso, incerto a tomar o coração do poeta, a enchê-

${ }^{122}$ HEIDEGGER, Os Conceitos Fundamentais da Metafisica: Mundo - Finitude - Solidão, p.236. Notemos que Heidegger usa o termo melancolia e não tédio, apesar de estar se referindo ao tédio profundo. Em nota, o tradutor diz que o sentido do termo "melancolia" em alemão, diversamente do português, significa exatamente o ânimo (-mut) pesado (Schwer) presente no tédio.

${ }^{123}$ PESSOA, Novas Poesias Inéditas, p.28.

${ }^{124}$ PESSOA, Obra Poética, p.513. 
lo de tédio e nada, a atravessar o poeta com uma insondável indiferença a tudo e a todos. Trata-se do tédio profundo, de um abismo a tocar a existência, tal como uma bruma que cai sobre a noite da alma e espalha uma indeterminada apatia sobre tudo - um tempo que nada diz e que sufoca o sentido de viver. Heidegger, em uma fala direcionada aos seus concidadãos, por ocasião do aniversário de sua cidade natal, em 1961, descreve o fenômeno do tédio de forma muito semelhante ao que acabamos de ler. Ele diz:

Aqui não encontramos nada determinado - não é esta ou aquela coisa, não é este ou aquele homem, não é esta ou aquela situação que nos entedia, mas neste "está um tédio" nada mais nos toca, tudo se torna tedioso, tudo vale tanto ou tão pouco quanto, porque um profundo tédio atravessa e afina toda nossa existência.

Será que está acontecendo isso conosco, a saber, que nos abismos de nossa existência, um tédio profundo, tal como uma névoa que tudo vai envolvendo, nos puxa e nos empurra para cá e para lá? ${ }^{125}$

Notemos que o pensador, tal como o poeta - que fala em maresia -, usa a palavra névoa para se referir ao estado do tédio profundo. Não há uma determinação precisa sobre o que o entedia. Tudo é tédio. Trata-se de um abismo existencial a envolvêlo, a mais profunda indiferença e apatia. Tal sentimento também é narrado por Álvaro de Campos. O poeta mal sabe definir o que sente. O tédio se instala, impregna seus ossos e inunda seu ser - o que resta é apenas o frio na alma. Ouçamos os versos, escritos em 1927:

O tédio que chega a constituir nossos ossos encharcou-me o ser,

$\mathrm{E}$ a memória de qualquer coisa de que me não lembro esfria-me a alma. ${ }^{126}$

Alguns anos mais tarde, em 1934, também encontramos a estagnação do tédio e do nada a tomar seu corpo inerte em cima da cama:

Estou cheio de tédio, de nada. Em cima da cama $[\ldots]^{127}$

Será mesmo em Bernardo Soares que encontraremos a exacerbação do tédio. Nele o torpor se intensifica. Ele é, sem sombra de dúvida, o poeta mais atravessado por esta tonalidade afetiva. Ele mesmo diz: "Em mim, o tédio é frequente [...]." ${ }^{128}$ São inúmeros os momentos que o guarda-livros nos fala da paralisia, do vazio e da não compreensão que o invadem,

\footnotetext{
125 HEIDEGGER, "700 Anos de Messkirch", p.6.

${ }^{126}$ PESSOA, Poesias de Álvaro de Campos, p.28; idem, Obra Completa: Álvaro de Campos, p.192.

${ }^{127}$ PESSOA, Álvaro de Campos: Livro de Versos, p. 242.

${ }^{128}$ PESSOA, Livro do Desassossego, p.262; idem, Livro(s) do Desassossego, p.360.
} 
[...] como se de sobre o fosso do castelo da alma se erguesse a ponte levadiça, nem restasse, entre o castelo e as terras, mais que o poder olhá-las sem as poder percorrer. Há um isolamento de nós em nós mesmos, mas um isolamento onde o que separa está estagnado como nós, água suja cercando o nosso desentendimento[...]. ${ }^{129}$

A ponte levadiça sobre o fosso da alma espelha a suspensão e a separação de um solo (ou da falta dele), diante do qual o vazio e a indeterminação se instalam. Há uma imobilidade interna e externa, acompanhada de um não saber que são como "água suja" parada. Não há uma clareza do que se vive, apenas a vaga constatação do indefinido. O Livro do Desassossego é tão trespassado por esta tonalidade afetiva - a palavra tédio é pronunciada 144 vezes - que gostaríamos de destacar um trecho que traduz de forma magistral aquilo que queremos expressar. José Gil se refere a esta passagem como "uma pequena fenomenologia do tédio." ${ }^{130}$ Diz Soares:

Ninguém ainda definiu, com linguagem com que compreendesse quem o não tivesse experimentado, o que é o tédio. $\mathrm{O}$ a que uns chamam tédio, não é mais que aborrecimento; o que a outros o chamam, não é senão mal-estar; há outros, ainda, que chamam tédio ao cansaço. Mas o tédio, embora participe do cansaço, e do malestar, e do aborrecimento, participa deles como a água participa do hidrogénio e oxigénio, de que se compõe. Inclui-os sem a eles se assemelhar. [...]

O tédio é, sim, o aborrecimento do mundo, o mal-estar de estar vivendo, o cansaço de se ter vivido; o tédio é, deveras, a sensação carnal da vacuidade prolixa das coisas. Mas o tédio é, mais do que isto, o aborrecimento de outros mundos, quer existam quer não; o mal-estar de ter que viver, ainda que outro, ainda que de outro modo, ainda que noutro mundo; o cansaço, não só de ontem e de hoje, mas de amanhã também, da eternidade, se a houver, do nada, se é ele que é a eternidade. Nem é só a vacuidade das coisas e dos seres que dói na alma quando ela está em tédio: é também a vacuidade de outra coisa qualquer, que não as coisas e os seres, a vacuidade da própria alma que sente o vácuo, que se sente vácuo, e que nele de si se enoja e se repudia.

O tédio é a sensação física do caos, e de que o caos é tudo. O aborrecido, o malestante, o cansado sentem-se presos numa cela estreita. O desgostoso da estreiteza da vida sente-se algemado numa cela grande. Mas o que tem tédio sente-se preso em liberdade fruste numa cela infinita. Sobre o que se aborrece, ou tem mal-estar, ou fadiga, podem desabar os muros da cela, e soterrá-lo. Ao que se desgosta da pequenez do mundo, podem cair as algemas, e ele fugir, ou doerem de as não poder tirar, e ele, com sentir a dor, reviver-se sem desgosto. Mas os muros da cela infinita não nos podem soterrar, porque não existem; nem nos podem sequer fazer viver pela dor as algemas que ninguém nos pôs. [...] $]^{131}$

O guarda-livros parte de sentenças negativas para dizer o que o tédio não é - o tédio não é só o aborrecimento do mundo, não é só o cansaço de ter que existir e nem somente o mal-estar de viver. O tédio também não é só um desgosto íntimo e

\footnotetext{
${ }^{129}$ PESSOA, Livro do Desassossego, p.262; idem, Livro(s) do Desassossego, p.361.

${ }^{130}$ GIL, Cansaço, Tédio, Desassossego, p.106.

${ }^{131}$ PESSOA, op. cit., p.347-348; idem, op. cit., p.394-395.
} 
espiritual e, nem tampouco, só um sentimento profundo do vazio das coisas. O tédio é mais que isso. O tédio, nos diz Gil, implica "a desvitalização ('a vacuidade prolixa das coisas); a paralisia do movimento da vida, e o mau estar (a que outros textos chamam 'angústia', 'horror' ou 'náusea') de viver. Mas a tudo isso, o tédio acrescenta uma dimensão maior [...]." ${ }^{132}$ Trata-se de um drama existencial de raízes profundas que percorre e aprisiona a alma e o corpo numa cela infinita - o mesmo que estar preso em liberdade. Em outro trecho do livro, o guarda-livros retoma a ideia da cela:

Mas este horror que hoje me anula é menos nobre e mais roedor. É uma vontade de não querer ter pensamento, um desejo de nunca ter sido nada, um desespero consciente de todas as células do corpo e da alma. E o sentimento súbito de se estar enclausurado numa cela infinita. Para onde pensar em fugir, se só a cela é tudo? ${ }^{133}$

Notemos que o poeta usa o verbo anular, fala de horror, do desejo de não pensar, de não ser. O tédio é a cela, é o muro e a algema invisíveis a acorrentar o espírito, é o drama de uma existência encarcerada, paralisada, em estado de pura inércia. Tudo está tomado pelo tédio profundo. A certa altura do livro, Vicente Guedes também proclama: “Cheguei àquele ponto em que o tédio é uma pessoa, a ficção encarnada do meu convívio comigo mesmo."134 Isto significa que ambos, Soares e Guedes, se veem dentro de uma existência encarcerada pelo tédio. Não há saída. O tédio é uma marca decisiva de seu tempo.

O caráter temporal do tédio profundo, apesar de ser, num primeiro momento, insignificante - dado que o tempo do relógio desaparece -, abrange o presente, o passado e o futuro. Esta é uma afirmação no mínimo paradoxal, pois, como pode uma profunda indiferença ao tempo abarcar o presente, o passado e o futuro? Busquemos auxílio na descrição fenomelógica de Soares sobre o tédio. Notemos que ali, o guarda-livros se refere ao cansaço de ontem, de hoje e do amanhã, delineando uma total indiferença à dimensão temporal. Para ele, a eternidade e o vazio do nada parecem significar a mesma coisa. Pois bem. Uma vez que o poeta se depara com o vazio presente na tonalidade afetiva do tédio e instalase "o mal-estar de ter que viver", abre-se um horizonte temporal que envolve o homem na totalidade. Heidegger chamou esta experiência unificadora de serenidade vazia. É exatamente a indiferença do tédio - lugar em que se perde o

\footnotetext{
132 GIL, Cansaço, Tédio, Desassossego, p.108.

133 PESSOA, Livro do Desassossego, p.80; idem, Livro(s) do Desassossego, p.263.

${ }^{134}$ Ibidem, p.348; ibidem, p.158.
} 
sentido de ser - o campo de possibilidade para uma experiência do tempo originária, a saber, o horizonte total, uno e homogêneo do tempo, instante em que presente, passado e futuro aparecem unificados e abarcam uma totalidade onde "tudo o que será, terá sido irreversivelmente" ${ }^{135}$, como nos diz Gil. Isto significa dizer que a temporalidade do tédio, aqui entendida a partir do banimento do próprio âmbito temporal, é capaz de possibilitar a abertura de uma totalidade que compreende a unidade dessas três dimensões em um horizonte originariamente unificador. Este é, sem dúvida, o lugar da criação. Este é o lugar da poesia, lugar que possui "o parentesco mais intrínseco que liga toda ação essencial na totalidade."136

Como dissemos anteriormente, não avançaremos na questão do tédio. No próximo capítulo, voltaremos nossa atenção para a angústia e toda a possibilidade que esta traz. Todavia, não poderíamos deixar de mencionar esta tonalidade afetiva tão presente no pensar de Heidegger quanto no universo de Pessoa, Campos, Soares e Guedes, e que demarca de modo inegável este tempo em que o homem se encontra ameaçadamente à deriva de si mesmo. Esta paragem nas terras do tédio nos fez, de alguma forma, interromper o fluxo do pensamento. Retomemos seu curso.

\subsection{A voz da técnica}

Tudo o que foi exposto até aqui nos fez enxergar a riqueza extraordinária do pensamento heideggeriano e da linguagem pessoana ao se voltarem para a técnica moderna. Ambos falam, de formas distintas, desse projeto de estruturação e organização de realidade que coloca tudo como disposição, como aquilo que é posto e disposto para uso e abuso de consumo, como energia para alguma coisa. Subjaz por traz da técnica uma força que, uma vez direcionada ao homem, determina também o seu modo de ser. Apesar se tratar de um desencobrimento explorador, a técnica não deixa de ser uma forma de desvelamento, é o modo como a realidade se faz hodiernamente. Neste sentido, não há como a técnica não estar presente em todos os aspectos da vida humana. A própria linguagem se encontra atravessada pelo domínio técnico. Mas, logo perguntamos: o que a técnica tem a

${ }^{135}$ GIL, Cansaço, Tédio, Desassossego, p.109.

${ }^{136}$ HEIDEGGER, Os Conceitos Fundamentais da Metafisica: Mundo - Finitude - Solidão, p.203. 
ver com a linguagem? Por que a língua se põe à mercê do domínio técnico? Estas são perguntas fundamentais para o nosso percurso. Algumas palavras se fazem, pois, necessárias.

Voltemos nossos olhares, em primeiro lugar, para o início do pensamento ocidental, quando aí se inicia a correspondência entre o pensamento e o que veio a chamar-se Lógica. A Lógica nasce na escola de Platão, mas é desenvolvida fundamentalmente por Aristóteles, considerado o pai da Lógica, com a tripartição da filosofia em Lógica, Física e Ética. Com esta tripartição, nascem as disciplinas que, por sua vez, se relacionam diretamente com seus objetos. Nessa relação, a determinação se dá da disciplina para o seu objeto. Isto significa que é a disciplina que determina aquilo que a coisa é e, consequentemente, a medida da sua verdade. Nos encontramos em meio a uma inversão da relação de determinação, pois é a disciplina a instância que decide o como e o porquê um objeto é conhecido. Porém, mais importante do que tais considerações históricas, são as consequências que daí resultam para o saber do lógos.

O termo "lógica" se diz logiké, em grego. Essa denominação significa aquilo que se refere ao lógos. Se acrescentamos o termo épistème, temos épistème logiké, que se atém ao saber que diz respeito ao lógos. Isto, entretanto, não é suficiente para entendermos a relação que a lógica tem com o lógos. Caminhemos um pouco mais. A Lógica se apresenta como a doutrina do pensamento correto. Entende-se, a partir disso, a correção do pensar segundo um critério de construção, formas e normas que regem o pensamento de maneira a ordená-lo, sendo o seu traço essencial o enunciar algo sobre algo. Encontramos aqui a determinação do pensar como um falar, fundamentado e assentado no enunciado. O lógos enunciativo é aquilo que diz o que uma coisa é e como dever ser. ${ }^{137}$ Isso determina um fechamento ao campo original da palavra, pois se pensar é enunciar algo sobre algo, nesse enunciar sonega-se algo da originariedade da palavra, na medida em que algo é assumido a partir de concepções e proposições previamente dadas. Há toda uma construção interna na lógica que determina o quê e o como da língua. Em primeiro lugar, sendo o enunciado uma representação de algo que não está presente, existe sempre uma correspondência direta das palavras com as suas representações; a segunda característica diz respeito a uma ligação de coerência entre os elementos

${ }^{137}$ Cf. HEIDEGGER, Lógica, p.37. 
do enunciado e ao raciocínio conclusivo que o enunciado deve apresentar. Para isso, utilizam-se regras, tais como, o princípio da identidade, lugar em que a representação de algo deve manter a sua identidade, como por exemplo, céu não pode ser árvore; o princípio da não-contradição, que diz que no enunciado não pode haver contradição entre os termos, ou seja, "A é A" e "A não é B" não podem ser verdadeiros ao mesmo tempo; e, por fim, o princípio do fundamento, que diz respeito à não casualidade do raciocínio, ou seja, há uma ordem que regula a ordenação e a sequência do enunciado. Esses são os conteúdos da Lógica, como saber do lógos, que regulam e determinam o enunciado. ${ }^{138}$ Há, portanto, uma consideração formal que se atém à forma e não à veracidade do conteúdo. Diz Heidegger:

A lógica incide apenas sobre as formas do enunciado, considera as formas das configurações fundamentais e as regras fundamentais do enunciar e, na medida em que esta consideração é ordenada e articulada, a lógica torna-se uma ciência. Ela é ciência das formas das configurações fundamentais e das regras fundamentais do enunciado. ${ }^{139}$

$\mathrm{Na}$ ciência da Lógica estamos totalmente enraizados em pressupostos que configuram e restringem o horizonte da linguagem - é o enunciado o fio condutor da linguagem. Este tipo de determinação se estende dos gregos até os nossos dias. Mas não é só isso! As fórmulas e regras que a Lógica impõe sobre a linguagem criam um domínio metodológico que garante o rigor dos seus preceitos e reforçam a ideia de que o dizer está a serviço do pensar e que a língua nada mais é do que "uma forma de expressão e de comunicação do pensamento."140

As consequências dessa compreensão nos levam de imediato a um outro aspecto da língua e sua relação com a dominação da técnica. Referimo-nos ao pensamento de Heidegger, apresentado na conferência Língua de Tradição e Língua Técnica, proferida em 18 de julho de1962, onde o filósofo alemão faz uma crítica ao pensamento de Humboldt, quando este infere que a língua é o âmbito intermediário entre o espírito humano e as coisas, é aquilo que se põe entre o sujeito e o objeto, é uma ferramenta de comunicação, é informação. ${ }^{141}$ Isto não significa que para o linguista a língua se reduza apenas a isto, mas, segundo Heidegger, daí

\footnotetext{
${ }^{138}$ Cf. HEIDEGGER, Lógica, p.38-41.

${ }^{139} \mathrm{Ibidem}, \mathrm{p}$.42. Mais à frente retomaremos a questão do enunciado e sua relação com a verdade.

${ }^{140}$ Ibidem, p.51.

${ }^{141}$ Cf. HEIDEGGER, Lingua de Tradição e Lingua Técnica, p.32-33.
} 
advém a capacidade da língua de absorver de forma extremada a dominação da técnica moderna. Uma vez que a técnica nivela e apresenta tudo a partir do seu aspecto mais próprio - o instrumental, é exatamente esta compreensão equivocada da língua que impera. Esta instrumentalização reduz a linguagem a um nível apenas operativo, algo que não só fecha a dimensão original da linguagem, mas, sobretudo, determina a sua função e o seu estatuto. Na visão de Heidegger, apesar de importante, a contribuição de Humboldt deixa de fora que o mais próprio da língua é o falar, que falar é essencialmente dizer e que dizer é levar uma coisa a aparecer. ${ }^{142}$ É graças ao dizer que a coisa se mostra. Na linguagem instrumental isso não acontece, o dizer é apenas um sinal, um símbolo, uma indicação ou instrução acerca de algo que não aparece. Pessoa escreve um poema intitulado "O contra-símbolo", em 1926, no qual expressa o seu entendimento sobre o tema:

Uma só luz sombreia o cais

Há um som de barco que vai indo.

Horror! Não nos vemos mais!

A maresia vem subindo.

E o cheiro prateado a mar morto

Cerra a atmosfera de pensar

Até tomar-se este como porto

E este cais a bruxulear

Um apeadeiro universal

Onde cada um 'spera isolado

Ao ruído - mar ou pinheiral? -

$\mathrm{O}$ expresso inútil atrasado.

E no desdobre da memória

$\mathrm{O}$ viajante indefinido

Ouve contar-se só a história

Do cais morto do barco ido. ${ }^{143}$

Os versos nos falam dos sentidos embotados por uma luz que é sombra, por um som que se esvai, uma nevoa que se impõe e que impede o pensamento. Trata-se de um lugar em que todos param e esperam por algo que não vem, que não chega. Nada se vê, o barco partiu do cais e a maresia impede a visão. O que fica é apenas a memória imprecisa de algo que se ouviu contar, do "cais morto do barco ido." Assim é o símbolo - a representação de algo que não se viu. O que há é apenas a

${ }^{142}$ Cf. HEIDEGGER, Língua de Tradição e Língua Técnica, p. 34. Deixamos aqui apenas a indicação do dizer como um mostrar. A questão do lógos apophantikòs será trazida no quarto capítulo, quando nos voltarmos para a questão da linguagem propriamente dita.

${ }^{143}$ PESSOA, Obra Poética, p. 507. 
representação, o aceno, a imagem cujo significado designa alguma coisa. Álvaro de Campos expressa vividamente sua irritação com o mal dos símbolos quando, em 1934, diz:

Símbolos? Estou farto de símbolos...

Mas dizem-me que tudo é símbolo.

Todos me dizem nada. [...]

Símbolos? Não quero símbolos... ${ }^{144}$

O poeta não quer saber dos símbolos. Ele está farto dos símbolos. O símbolo sinaliza algo, dá instrução sobre alguma coisa que não se mostra, que não está presente e que não diz nada! O modo da língua determinado pela técnica se insere no mesmo padrão do esquema das máquinas: segue o modelo unívoco de produção de sinais e códigos que asseguram, de forma inequívoca, apenas a rapidez da comunicação. Através da língua técnica cria-se um mundo de signos que permitem uma apreensão cada vez maior de informações técnicas. Nisto repousa a eficácia dos computadores e dos sistemas formais de informação. No mundo das máquinas, o modo de comunicação é basicamente serial - segue o fluxo de impulsos e correntes elétricas - os quais outorgam este mesmo padrão a sua produção de mensagens de modo a estabelecer uma eficácia e precisão. Há uma espécie de programação que regula a linguagem e que visa apenas a comunicação de dados e o domínio de seu conteúdo. Há por trás disso uma engrenagem tão bem entrosada que é ela que prescreve como a língua é ou deve ser. Também Caeiro, em "O guardador de rebanhos", escrito em 1914, faz uma crítica contundente a sua própria linguagem, por vezes atravessada de símbolos:

Se às vezes digo que as flores sorriem

E se eu disser que os rios cantam,

Não é porque eu julgue que há sorrisos nas flores

E cantos no correr dos rios...

É porque assim faço mais sentir aos homens falsos

A existência verdadeiramente real das flores e dos rios.

Porque escrevo para eles me lerem sacrifico-me às vezes

À sua estupidez de sentidos...

Não concordo comigo, mas absolvo-me,

Porque só sou essa cousa séria, um intérprete da Natureza,

Porque há homens que não percebem a sua linguagem,

Por ela não ser linguagem nenhuma. ${ }^{145}$

${ }^{144}$ PESSOA, Obra Poética, p.394-395; idem, Obra Completa: Álvaro de Campos, p.310.

${ }^{145}$ Ibidem, p.220; idem, Obra Completa de Alberto Caeiro, p.60. 
Como vemos, o poeta justifica o uso de figuras de linguagem com o claro objetivo de despertar nos homens falsos alguma percepção ou sensação real das coisas. Ainda que contrariando a si próprio, assim o faz para que possa ser lido e compreendido. Caeiro justifica a sua existência como "intérprete da Natureza" exatamente porque os homens falsos "não percebem a sua linguagem", se encontram longe da sua morada, que é a verdade do ser. É por isso que o poeta afirma com veemência que a linguagem dos homens é "linguagem nenhuma". Trata-se de uma afirmação que reverbera nas palavras de Heidegger quando diz que a linguagem se tornou tão somente um habitáculo dos afazeres produtivos dos homens. ${ }^{146}$

Reduzir a linguagem a um mero instrumento de comunicação e informação é uma proposição um tanto superficial. O domínio que a língua técnica exerce sobre a linguagem faz com que esta última sirva apenas como pano de fundo para a primeira, ou seja, a linguagem é basicamente um veículo a serviço da técnica. Tratase de um domínio absoluto que se lança contra o mais próprio da língua que é o dizer como mostrar, como o fazer aparecer da realidade. ${ }^{147} \mathrm{Na}$ língua técnica ignorase totalmente o aparecer da coisa como coisa. Esta é a maior agressão contra a linguagem, e nem sequer nos damos conta que isso acontece. E não só isso! Não podemos esquecer que esta com-posição envolve também o homem, na medida em que é ele que assegura e dispõe a linguagem neste modo de comunicação. Campos chega mesmo a questionar o papel do homem nesta engrenagem, no poema "Psiquetipia (Ou Psicotipia)", escrito em 1933, quando diz:

Símbolos. Tudo símbolos...

Se calhar, tudo é símbolos...

Serás tu um símbolo também? ${ }^{148}$

Os versos ressoam claramente a ameaça que o símbolo traz contra o próprio homem. E mais! Na medida em que ele é o único vivente capaz da palavra, tal realidade prescreve também o modo como ele deve pensar e agir, o que acaba por afastá-lo da sua dimensão mais própria. ${ }^{149}$ Vemos, assim, que não só o coração do homem é determinado pela máquina, mas, a própria forma da língua. Com isso, a

\footnotetext{
${ }^{146}$ Cf. HEIDEGGER, Carta sobre o Humanismo, in:

${ }^{147}$ Cf. HEIDEGGER, Língua de Tradição e Língua Técnica, p.37.

${ }^{148}$ PESSOA, Obra Poética, p. 387; idem, Obra Completa: Álvaro de Campos, p. 286.

${ }^{149}$ Cf. HEIDEGGER, op. cit., p. 30 .
} 
experiência, a gênese fundadora do aparecer que possibilitou a fala morreu. Referimo-nos a uma experiência de pertença e comunhão com o mundo. Esta mesma noção de pertencimento (appartenance) é aventada por Paul Ricoeur, no livro Leituras 3, onde o autor afirma:

Se nos tornamos cegos para essas modalidades de enraizamento e de pertencimento que precedem a relação de um sujeito com objetos é porque ratificamos de maneira não-crítica um certo conceito de verdade, definido pela adequação a um real de objetos e submetido ao critério da verificação e da falsificação empíricas. O discurso poético questiona precisamente esses conceitos não criticados de adequação e de verificação. Ao fazer isso, ele questiona a redução da função referencial ao discurso descritivo e abre o campo de uma referência não-descritiva do mundo. ${ }^{150}$

Vemos, através deste trecho, que a linguagem poética se coloca exatamente no lugar de questionar a compreensão reducionista da verdade como adequação e representação ${ }^{151}$, e abre um campo, uma dimensão, um horizonte de sentidos, os quais precedem a relação sujeito-objeto e se atêm, como ele mesmo diz, a "uma referência não-descritiva do mundo". Entendemos que o autor se refere a um entendimento totalmente atrelado a uma experiência de linguagem originária que se firma nas ideias de enraizamento e pertencimento, algo que ressoa claramente na poética de Caeiro. Para o poeta, nenhuma filosofia supera aquilo que nos é dado pela experiência autêntica de ser tocado, atravessado, perpassado por um tal modo de ser que determina tudo o que é e há.

É certo que vivemos uma era muito pobre de experiências, uma era em que o automatismo conduz nosso caminhar, onde nossos sentidos estão impregnados de informações que nos chegam por todos os lados e de todas as formas. É certo que a cada dia uma novidade surge deixando a massa humana ávida por novos gadgets, pequenos aparelhos que vibram, tocam e apitam nos lembrando esta relação quase simbiótica do homem com a máquina. Toda essa valorização excessiva dos recursos tecnológicos acaba por distrair nossos sentidos e nos afasta daquilo que é o aberto da experiência, esse lugar que nos coloca disponíveis para que algo chegue até nós. De fato, nossa vida empobreceu, fragmentou-se, tornou-se fluida, e no meio disso encontra-se o homem, cheio de opiniões, mas vazio de sentido. Walter Benjamin, em seu texto Experiência e Pobreza já nos alertava para uma nova forma de

\footnotetext{
${ }^{150}$ RICOEUR, Leituras 3, p.187-188.

${ }^{151}$ A questão da verdade e sua relação com a linguagem será tratada no quarto capítulo de nossa tese.
} 
escassez e penúria gerada pela tecnologia. Ouçamos sua voz: "Uma forma completamente nova de miséria recaiu sobre os homens com esse monstruoso desenvolvimento da técnica." 152 Hannah Arendt, em A Condição Humana, vai além e nos mostra uma certa perplexidade a respeito da técnica que levou o ser humano a perder a capacidade de pensar. Com todo esse automatismo, ela diz: “[...], passaremos sem dúvida, à condição de escravos indefesos, não tanto de nossas máquinas quanto de nosso know-how, criaturas desprovidas de raciocínio, à mercê̂ de qualquer engenhoca tecnicamente possível, por mais mortífera que seja."153 Pessoa, em um texto publicado na Revista de Comércio e Contabilidade, em 1926, também não deixa de exteriorizar sua inquietude sobre a questão do pensar quando diz:

A tendência moderna para a organização e coordenação, quanto possível perfeita, dos serviços de modo a torná-los mais simples e mais rápidos, deu em resultado a invenção, constantemente crescente, de sistemas, processos, móveis e aparelhos diversa e diferentemente conducentes a esse fim. Alguns desses processos, desses móveis e dessas máquinas são muito engenhosos; quase todos são úteis ou aproveitáveis. Mas o emprego deles, sejam quais forem, deve obedecer sempre a um critério superior. Um sistema não é uma cabeça; um móvel não é gente. Todos os processos e todos os aparelhos resultarão elementos inúteis de organização se as cabeças dos indivíduos que os empregam não estiverem organizadas também. E essas cabeças estarão organizadas se estiver organizada devidamente a mesma parte do corpo do chefe que os dirige. Assim como se podem escrever asneiras com uma máquina de escrever do último modelo, se podem fazer disparates com os sistemas e os aparelhos mais perfeitos para ajudar a não fazê-los. Sistemas, processos, móveis, máquinas, aparelhos são - como todas as coisas mecânicas e materiais - elementos puramente auxiliares. $\mathrm{O}$ verdadeiro processo é pensar; a máquina fundamental é a inteligência... ${ }^{154}$

O longo trecho nos mostra a preocupação de Pessoa quanto ao fato de o homem de seu tempo estar envolto por processos, aparelhos e máquinas que o afastam da capacidade de pensar. O poeta considera tais aparatos inúteis se "as cabeças dos indivíduos que os empregam não estiverem organizadas também.” O pensamento, antes valorizado, perde espaço na modernidade para as formas ativas da vida, para a técnica. O que conta é know-how, mencionado por Arendt. A pensadora, que em nossa epígrafe fala da perda de todos os pilares tradicionais, entende que é necessário que o ser humano se liberte e se descondicione dos padrões técnicos, para que se resguarde a possibilidade de pensar. Todo pensamento envolve um

\footnotetext{
152 BENJAMIN, Obras Escolhidas I: Magia e Técnica, Arte e Política, p.124.

153 ARENDT, A Condição Humana, p. 11.

${ }^{154}$ PESSOA, Páginas de Pensamento Político, p.120.
} 
"tomar distância" do nosso envolvimento imediato com as coisas. Se não houver esse recuo, não existe a possibilidade de pensar, e, tampouco, a possibilidade de viver a experiência, uma vez que ela também exige um distanciamento do mundo das aparências. O homem desviou-se de si mesmo, desviou-se do sentido da vida e não vê o grande perigo que o ameaça.

Ouvimos de um grande poeta alemão que na vigência extrema do perigo cresce também o que salva. Pessoa também não se emudeceria diante de tal ameaça. Ele diz: "Extraviámo-nos a tal ponto que devemos estar no bom caminho." $155 \mathrm{O}$ extravio há de ser, pois, um reenvio ao verdadeiro sentido da vida, à retomada do próprio, da singularidade - lugar onde se instala a vitalidade da vida, a reassunção do sentido de ser. O tempo da noite do mundo e sua tamanha indigência nos acena como a possibilidade de uma mudança. Entretanto, tal mudança somente será possível quando os homens encontrarem a sua própria essência. ${ }^{156}$ Só que, para isso, é preciso chegar primeiro ao abismo. Este é o lugar da poesia. Este é o lugar do poeta. São os poetas que chegam primeiro ao abismo e vertem em palavras o destino da era do mundo de modo a que não nos enganemos e nos desviemos da possibilidade de um caminho em direção à própria salvação do homem. ${ }^{157}$ Voltemonos, agora, para a promessa deste caminho.

\footnotetext{
${ }^{155}$ PESSOA, Ultimatum e Páginas de Sociologia Politica, p.3.

${ }^{156}$ Cf. HEIDEGGER, "Para quê poetas?", in: , Caminhos de Floresta, p.311.

157 No texto "Para quê poetas?", Heidegger usa o vocábulo alemão Heile. Fazermos notar que das Heile possui a mesma raiz que das Heilige, santo ou sagrado. Segundo o tradutor, em nota, "esta família de termos congrega uma gama de sentido bem mais vasta, a qual abrange a própria noção de salvação e graça." Ibidem, p.339.
} 


\title{
3 \\ À escuta do silêncio
}

\author{
I heard, as if I had no Ear \\ Until a Vital Word \\ Came all the way from Life to me \\ And then I knew I heard. \\ I saw, as if my Eye were on \\ Another, till a Thing \\ And now I know 'twas Light, because \\ It fitted them, came in. \\ I dwelt, as if Myself, were out, \\ My Body but within \\ Until a Might detected me \\ And set my kernel in. [...]
}

- $\quad$ Emily Dickinson ${ }^{158}$

O título diz: à escuta do silêncio. De pronto, algo nos causa uma estranheza. Falamos de silêncio. Logo, a pergunta: como podemos estar à escuta de algo que é silêncio? O que caracteriza o silêncio não é precismante a ausência de som? Como se caracteriza esta escuta? Sabemos que o silêncio nos remete ao calar, a uma vigência subjetiva, ligada ao comportamento humano. Entretanto, o calar não significa silenciar. Muito é dito com o silêncio. Em contrapartida, o muito falar pode não dizer nada. ${ }^{159}$ Álvaro de Campos exprime no poema, escrito em 1931, o soar do silêncio. Ouçamos seus versos:

É inútil prolongar a conversa de todo este silêncio.

Jazes sentado, fumando, no canto do sofá grande -

Jazo sentado, fumando, no sofá de cadeira funda,

Entre nós não houve, vai para uma hora,

Senão os olhares de uma só vontade de dizer.

Renovávamos, apenas, os cigarros - o novo no aceso do velho

E continuávamos a conversa silenciosa,

Interrompida apenas pelo desejo olhado de falar... $[\ldots]^{160}$

Ainda que inerte, imóvel, acomodado no fundo do sofá, o silêncio fala. A ausência de som não impede a longa conversa que se estende no decorrer das horas. Os versos de Campos perpetuam no poema uma eloquente conversa muda que se

\footnotetext{
${ }^{158}$ DICKINSON, Emily Dickinson: Não sou Ninguém, p.160-161. Tradução de Augusto de Campos: "Ouvi, como que sem Ouvido, / Até que uma Palavra enfim / Chegou da Vida para mim / E ouvi o não ouvido. // Olhei, como sem perceber, / De um outro olho, até que um dia / Algo que - a Luz eu não sabia - / Veio e ensinou meu Olho a ver. // Vivi, como de Mim ausente, / só Corpo, sem ter $\mathrm{Eu}$, / Até que alguma ação potente / Meu cerne preencheu. // Maiúsculas da autora.

${ }^{159}$ Cf. HEIDEGGER, Ser e Tempo, p.227-228.

${ }^{160}$ PESSOA, Obra Completa: Álvaro de Campos, p.268.
} 
estende silenciosamente através de olhares e cigarros renovados no velho cigarro aceso. O silêncio fala com os olhos. Poderíamos dizer que o silêncio permeia a conversa, ele é o meio, o entre - o próprio elemento do dizer.

O silêncio também remete para o nada, para o sossego da calada da noite, para o momento prenhe de quietude ou mesmo de mistério - aquele instante em que algo se põe entre nós e o mundo, como nos falam os versos de 1914, de Alberto Caeiro:

[...] E depois, fechada a janela, o candeeiro aceso,

Sem ler nada, sem pensar em nada, nem dormir,

Sentir a vida correr por mim como um rio por seu leito,

E lá fora um grande silêncio como um deus que dorme. ${ }^{161}$

A janela fechada, a luz acesa, a ausência de pensamento e de sono reforçam a ideia de que o grande silêncio de fora se contrapõe à vida que pulsa e corre como a água do leito do rio. Caeiro sente a vida correr dentro de si. Do lado de fora, é o fim do dia. O silêncio atravessa o que está fora. A natureza se cala, como um deus que dorme. Entretanto, o silêncio que se põe entre o poeta e o mundo de fora, não se reduz apenas a algo da esfera intramundana. Ele é o médium, o elemento fundamental para um outro modo de ser do homem. É preciso o silenciar do mundo para que a vida aconteca. É preciso que o silêncio seja. É preciso o abandono a uma escuta amorosa que se faz desde e como silêncio, porque a "insistência de tal ressonância", nos diz Fogel, "se evidência como a vigência de transcendência."162 É desde o ressoar nesta participação que se abre uma possibilidade de ser. Soa estranho o que acabamos de dizer, pois, como afirmar que o silêncio pode determinar um tal modo de ser? Lembremos que, em alemão, o vocábulo determinar é bestimmen. ${ }^{163} \mathrm{O}$ termo é formado pelo prefixo be-, que modula o verbo para um movimento incoativo, denotando o início de uma ação, e -stimmen que significa afinar, sonar, tonar. Em português, o prefixo verbal -be corresponde ao en-. Bestimmen é, pois, en-toar. O que resulta desta análise é que a determinação à qual nos referimos é o mesmo que entoar, fazer soar, uma afinação; como no gesto do maestro que no primeiro toque entrega ao silêncio todo o porvir da sinfonia. Lembremos ainda do vocábulo Stimmung, que traduzido precariamente para o

\footnotetext{
${ }^{161}$ PESSOA, Obra Poética, p.228; idem, Obra Completa de Alberto Caeiro, p. 73. 162 FOGEL, Da Solidão Perfeita, p.221.

163 A análise da palavra bestimmen é magistralmente desenvolvida por Harada, no texto "Da Experiência". Cf. HARADA, Coisas, velhas e novas, p.56-60.
} 
português por disposição, humor, também diz respeito a uma estrutura de afinação e sintonização. Falamos, pois, de um silêncio que recolhe em si a totalidade do som, sua ausência e presença: a sintonia perfeita. Falamos de um silêncio profundo, de sentido ontológico, que toca a nossa existência e nos cala. Entrentanto, é preciso que se diga: não nos referimos, de modo algum, a algo de uma esfera solipsista, intimista, pautada pelo eu, pela subjetividade. Isso, como veremos, é algo que precisa ser perdido para que o silêncio venha a ser em seu sentido próprio. Somente em uma fala autêntica é que o silenciar se põe em sentido próprio. ${ }^{164} \mathrm{Em}$ acréscimo, nos diz Duarte:

o autêntico falar que diz algo significativo só pode fazê-lo se já se encontrar previamente aberto e perpassado pela escuta do caráter mostrador da linguagem, isto é, na medida em que deixa dizer o som do silêncio (das Geläute der Stille) ou o rio do silêncio (Strom der Stille) que nada exprimem, mas que possibilitam toda expressão, tanto a que revela quanto a que oculta. ${ }^{165}$

Isto significa que o falar autêntico só se deixa dizer se estiver previamente transpassado por uma escuta capaz de ouvir o dizer da linguagem, mas, para isso, é preciso uma abertura prévia capaz de acolher o silêncio. Entendemos que a relação do poeta com a palavra acontece nesta esfera. Seabra, em Fernando Pessoa ou o Poetodrama, diz: "E falar não é para o poeta, dizer acima de tudo o indizível, o que está para além de todas as palavras, deixar falar o próprio silêncio?"166 O poeta é, pois, aquele que se abre a essa escuta silenciosa, a única capaz de fazer verter a linguagem originária, plena de sentido. $\mathrm{O}$ silenciar em sua essência - aquilo que subjaz como força geradora do silêncio - só brota a partir dessa abertura, dessa sintonia com um modo todo próprio de ser do homem. É somente quando esta abertura se interpõe que o dizer se torna próprio, autêntico. "O silêncio", nos diz Fogel,

é a presença do insondável do sentido da linguagem, de sua irrupção súbita, gratuita, livre, transcendente - uma presença ausente; uma ausência presente. Doacao. Pura doação. Onde há, onde e quando se faz silêncio, quer dizer, na linguagem autêntica ou na fala que fala desde silêncio, este acontecimento gratuito, abissal, livre e transcendente é sempre celebrado, festejado, isto é, relembrado. Tal fala é sempre memória deste imemorial, quer dizer, recordação do nada, do gratuito, do absoluto, como pura doação. Assim, desta maneira, evidência-se sempre o mistério da linguagem. ${ }^{167}$

\footnotetext{
${ }^{164}$ Cf. HEIDEGGER, Ser e Tempo, p. 228.

${ }^{165}$ DUARTE, Heidegger e a linguagem: do acolhimento do ser ao acolhimento do outro, p.147.

166 SEABRA, Fernando Pessoa ou o Poetodrama, p.41.

${ }^{167}$ FOGEL, O Desaprendizado do Símbolo, p.45.
} 
Vemos que subjaz por traz do silêncio algo insondável, memória imemoriável, que se doa como uma presença ausente e deságua em uma fala autêntica, plena de sentido, em pura gratuidade. Para isto, o homem deve deixar fluir o rio do silêncio, deve fazer de sua palavra uma escuta, um acolhimento, um abrigo, de modo que nessa experiência, as águas desse rio possam forjar, cunhar e modelar a própria vida. O silêncio é "a metalurgia do próprio, da identidade"168, nos diz Fogel. O único lugar possível de encontro com o si-próprio. Voltemos ao título. Ele diz: à escuta do silêncio. Voltemos nossos ouvidos para isso.

\subsection{A angústia: perdendo para encontrar}

À guisa de entrarmos no tema da angústia de modo apropriado, faz-se necessário recuperarmos, ainda que brevemente, o ponto de partida que nos leva até a questão que desejamos examinar. É notório o fato de que o pensar de Heidegger desmoronou a cristalizada estrutura da metafísica que jazia descrente há muito tempo. É com ele que passamos a ter a compreensão de que toda a história do pensamento ocidental, de Platão até Nietzsche, é determinada pelo esquecimento do ser. Trata-se de um esquecimento que se consolida na própria ausência sobre a questão e nos deixa como legado uma grande lacuna. O pensador se refere a um tipo de pensamento concebido pela tradição que firma-se como um pensar sobre o ser, mas basta apenas um olhar atento para se depreender que o que está em jogo é o ente e aquilo que o ente é. Heidegger entende que na tentativa de compreender o ente em seu ser, a tradição metafísica, esquecendo-se da diferença ontológica entre ser e ente, perguntou pelo ser e respondeu entitativamente, ou seja, o questionamento sobre o ser partiu sempre de um horizonte de compreensão determinado pelo ente, e, nesse sentido, a questão mesma do ser não foi colocada. Ao pensar o ser, mas deter-se no ente, equipara-se o ôntico ao ontológico e esquecese da diferença entre ambos. De modo a romper com a estrutura herdada especialmente da filosofia moderna iniciada com Descartes e, mais tarde, efetivada por Kant com o primado do sujeito - note-se que a inversão proposta pela centralidade do eu em relação à filosofia antiga, que se detinha na presença, não

${ }^{168}$ FOGEL, Da Solidão Perfeita, p.225. 
elimina a questão acerca do esquecimento do ser, mas, leva, como vimos no capítulo anterior, a que se coloque no centro da questão a subjetividade - Heidegger busca encontrar um caminho de pensar um sentido do ser que ultrapasse a dualidade estabelecida pelo par sujeito-objeto e que se mostrou tão desfavorável na compreensão do que seja o homem.

Ser e Tempo, publicado em 1927, é o caminho pelo qual o pensador alemão vai perscrutar, através de uma abordagem fenomenológica-hermenêutica, a existência humana. A analítica existencial proposta pelo filósofo parte das considerações de que o Dasein ${ }^{169}$ é sempre um ser-no-mundo, que a sua cotidianidade mediana é largamente determinada pela sua compreensão das coisas e o que determina essa compreensão é o contexto no qual as coisas estão inseridas. É precisamente o exame da situação do homem inserido no mundo que será determinante para a sua compreensão. Por outras palavras: O Dasein se encontra diretamente relacionado com a existência do homem, é sempre um ser-no-mundo em meio a outros entes e só se determina efetivamente a partir de uma interrelação incessante com esse mundo, numa perspectiva cotidiana, em suas ocupações do diaa-dia. Vemos, com isto, que a relação do homem com o mundo passa, obrigatoriamente, por uma rede de referências extremamente entrelaçadas, na qual cada coisa se mostra como é, justamente, porque ocupa um determinado lugar nessa rede. É a cotidianidade mediana que fornece ao Dasein as orientações necessárias e suficientes para que ele possa construir o projeto de sua existência - é no existir do homem que se decide a respeito do ser do homem. Com isso, é possível afirmar que o Dasein é o homem inserido em um processo de compreensão do mundo se fazendo no próprio mundo. Por isso, qualquer teoria dada a posteriori, seja ela de ordem antropológica, psicológica ou biológica é estéril e estanque para dar conta de um modo de ser que se faz no fazer que nós mesmos somos.

Diante do esboço traçado, voltemo-nos para o tema da angústia prorpriamente dito. Em um dado momento da analítica existencial de Ser e Tempo, mais especificamente no $\S 40$, o filósofo se detém sobre a tonalidade afetiva da

\footnotetext{
${ }^{169}$ No sentido de criarmos uma unidade para as diferentes traduções, optamos por manter os termos presença e ser-aí no original alemão Dasein. Tendo sempre em mente que o Dasein é um aceno ao homem cujo modo ser é existência - um chamado à experiência de existir na abertura de ser, e, portanto, distancia-se da compreensão dada pela tradição, na qual o homem está relacionado ao sujeito, a uma estrutura da subjetividade.
} 
angústia como lugar privilegiado de possibilidade de se enxergar as polaridades do real. Faz-se importante esclarecermos, de antemão, que não nos referimos aqui ao estado psicológico da angústia, mas ao lugar em que o Dasein experimenta o ser do ente como nada. É a angústia, nomeada originária, que abre o mundo como mundo - lugar que abrange a totalidade de tudo que é. Na angústia perdemos o referencial no qual estamos imersos e somos arrastados a uma outra compreensão de mundo. Somos arrancados de um estar-já-lançados para um novo habitar, compreendido existencial e ontologicamente como uma nova forma de ser, uma forma mais originária de perceber o real. De modo a trazer alguns desses elementos para a nossa análise, colocamos as perguntas: qual seria o lugar que a experiência da angústia ocupa na poesia pessoana? A multiplicação de eus poderia ser constituída pela experiência do vazio que angústia traz? Haveria nesse outrar-se uma experiência autêntica de angústia? Muitas são as perguntas. Busquemos algum caminho.

A angústia é um tema que certamente perpassa os poemas de Fernando Pessoa, os versos de Álvaro de Campos e a prosa de Vicente Guedes e de Bernardo Soares. São inúmeros os poemas de uns e os trechos de outros que nos remetem ao estranhamento radical, ao não estar em casa, ao estado profundo da angústia, à estranheza que põe em questão o próprio existir. Certamente não nos furtaremos à grandeza desses versos à medida em que o nosso texto por eles clamar. Mas, a fim de não cairmos no lugar-comum embrenhando-nos de imediato nos poemas, gostaríamos de iniciar nossa travessia através de uma carta de Pessoa endereçada ao grande amigo Mário de Sá-Carneiro, uma carta que nos mostra que a angústia também fez morada na vida do poeta. Todavia, logo indagamos: o que há de novo nisso? Por certo não seríamos ingênuos a ponto de imaginar que o poeta do desassossego não teria sido ele próprio trespassado por essa tonalidade afetiva. Bem sabemos que angústia e criação andam de mãos dadas e que, na maioria das vezes, a obra explica a vida e vice-versa. É notória no mundo pessoano a frase de Octávio Paz que diz: "Los poetas non tienen biografia. Su obra es su biografía"170, ou, ainda, a referência de Teresa Rita Lopes à "obra-vida" de Pessoa, ou, mesmo, a frase de Richard Zenith que diz que "é evidente que os heternónimos e outras personagens literárias de Pessoa eram expressões autobiográficas, reflexões e personificações do

\footnotetext{
170 Nos referimos à frase de Octávio Paz, proferida em Fernando Pessoa: el desconocido de sí mismo, um texto que prefaciou o livro de poesias de Fernando Pessoa, traduzido para o espanhol pelo poeta mexicano.
} 
que o verdadeiro autor era, ou do que gostaria ser, pelo menos num recanto da sua vasta alma." 171 Apesar de sabermos que vida e obra andam juntas, a vida não deixa de ser um elemento que fala da poesia, um elemento constitutivo que produz sentido dentro do próprio escopo da obra. Concordamos com Antônio Candido, em Literatura e Sociedade, que não há como dissociar texto e contexto, e que só podemos entender a obra em sua integridade na medida em que há um encontro de sua estrutura interna com elementos externos, que não se mostram como causa ou significado da obra, mas como algo que exerce uma parcela importante na coesão do todo, deixando, portanto, de ser externo para se tornar interno. Diz o autor:

É o que vem sendo percebido ou intuído por vários estudiosos contemporâneos, que, ao se interessarem pelos fatores sociais e psíquicos, procuram vê-los como agentes da estrutura, não como enquadramento nem como matéria registrada pelo trabalho criador; e isto permite alinhá-los entre os fatores estéticos. ${ }^{172}$

Para Candido, ambos os fatores são fundamentais para qualquer análise, e "pretender definir sem uns e outros a integridade estética da obra é querer, como só o barão de Münchhausen conseguiu, arrancar-se de um atoleiro puxando para cima os próprios cabelos." ${ }^{173}$ Por outras palavras: os referenciais externos à obra se tornam internos e devem ser considerados na medida em que essas dimensões fazem parte da própria obra, ou melhor, são inerentes à ela. Esses referenciais também nos falam da poesia, não são meras análises sociológicas ou psicológicas. Roland Barthes, em O Prazer do Texto, corrobora esta ideia quando afirma que a nova crítica consolida a busca da explicação para a obra na vida do autor que a produziu. Para o escritor francês, como instituição, o autor está morto, todavia, ele entende que, “[...] no texto, de uma certa maneira, eu desejo o autor: tenho necessidade de sua figura [...], tal como ele tem necessidade da minha [...]. ${ }^{174}$

Cientes de que a trama que compõe a poesia pessoana tece também sua própria vida ou vice-versa, ao enfatizarmos o ponto de partida com uma carta pessoal, desejamos apenas expressar o fato de entendermos que é exatamente a angústia existencial do poeta - essa capacidade esvaziar-se de si mesmo - que determinou marcadamente toda a sua criação poética colocando em cena os diversos atores que, ao longo de sua breve vida, encenariam com ele o grande teatro

\footnotetext{
${ }^{171}$ ZENITH, "Sobre a heteronímia", in: PESSOA, Prosa Íntima e de Autoconhecimento, p.139.

${ }^{172}$ CANDIDO, Literatura e Sociedade, p.14.

${ }^{173}$ Ibidem, p.22.

${ }^{174}$ BARTHES, O Prazer do Texto, p.38.
} 
que foi a sua engendrada obra. Por certo não cederemos à tentação de refazer o percurso de sua vida. Suas ausências e vazios deixaram poemas. O que importa é a obra em sua potência criativa, e esta transcende a vida do poeta. No sentido de iniciarmos esse caminho, ouçamos a voz de Pessoa em carta ao grande amigo:

Lisboa, 14 de março de 1916.

Meu querido Sá-Carneiro:

Escrevo-lhe hoje por uma necessidade sentimental — uma ânsia aflita de falar consigo. Como de aqui se depreende, eu nada tenho a dizer-lhe. Só isto - que estou hoje no fundo de uma depressão sem fundo. $\mathrm{O}$ absurdo da frase falará por mim.

Estou num daqueles dias em que nunca tive futuro. Há só um presente imóvel com um muro de angústia em torno. A margem de lá do rio nunca, enquanto é a de lá, é a de cá, e é esta a razão íntima de todo o meu sofrimento. [...]

Pouco mais ou menos isto, mas sem estilo, é o meu estado de alma neste momento. [...] Dói-me a vida aos poucos, a goles, por interstícios. Tudo isto está impresso em tipo muito pequeno num livro com a brochura a descoser-se. $[\ldots]^{175}$

Pelo tom imprimido, é possível percebermos, que a angústia assola o poeta, o paralisa, o coloca em suspensão, em um lugar sem futuro: no nada do lugar nenhum, no fundo sem fundo da angústia. Dela depreendemos o sofrimento mudo, a voz calada pela dor, o estranhamento de margens que nunca se encontram - o silêncio profundo. Trata-se da dor contida, de um mundo que desmorona, de uma vida que se desfaz, uma tônica que, sem sombra de dúvida, permeou a vida do poeta. São muitos os poemas a relatar o estranhamento, a imobilidade, o não ser nada, o estranhamento, o estar fora de casa. Não se trata, entretanto, de pensarmos a angústia como um estado da alma propício para o poético como pensaram os românticos ao buscarem na poesia a expressão mais completa do espírito do autor. ${ }^{176}$ Por certo, tomamos esse termo depurado de qualquer resíduo de ordem psicológica. Estamos a falar da angústia existencial, da angústia originária. Falamos da tonalidade afetiva que, abrangendo a totalidade de tudo que é, abre o mundo como mundo e nos arrasta a um outro habitar, a uma nova compreensão do real. Mas do que trata este fenômeno?

De acordo com Heidegger, a angústia é uma uma disposição privilegiada de possibilidade ontológica, na qual o horizonte ôntico se rasga de modo que o Dasein

175 PESSOA, Escritos Íntimos, Cartas e Páginas Autobiográficas, p.123. Itálico nosso.

${ }^{176}$ Cf. SCHLEGEL, O dialeto dos Fragmentos, frag. 116, p.64. 
venha a se colocar diante do seu mais próprio. Todavia, isto não significa que o se colocar diante do seu mais próprio seja algo simplesmente dado. Não. Por isso, logo indagamos: como se dá, numa perspectiva fenomenológica, essa possibilidade de encontro? Diferentemente de uma análise ôntico-existenciária, na qual o estar jálançado no mundo das ocupações apresenta-se como em fuga de si mesmo - uma privação cujo caminho encontra-se totalmente obstruído e fechado -, trata-se de seguirmos aqui os passos de uma interpretação ontológico-existencial, a qual só é possível de acontecer na abertura constitutiva do Dasein. Tentemos de outra forma: tal como falávamos no início do capítulo em referência ao silêncio, o mundo dado, no qual nos encontramos sempre já lançados, é um solo inapropriado para a questão da angústia originária, pois, nesse âmbito, há uma fuga que impede que o Dasein se coloque diante de si mesmo - tal desvio o leva para longe dessa dimensão originária. Todavia, na medida em que esse desvio se coloca fenomenologicamente como uma possibilidade de apreensão daquilo do que se foge, isto significa que o próprio movimento ôntico do afastamento pode ser a promessa de uma experiência ontológica, e, nesse caso, quanto mais originário for o fenômeno de abertura, maior a possibilidade de se chegar ao ser do Dasein.

Heidegger entende que existe um nexo ontológico, uma relação muito próxima, entre angústia e medo, e, de tal sorte, que muitas vezes um é compreendido pelo outro. Daí a necessidade de uma análise mais cuidadosa no sentido de distinguirmos aquilo que permeia o próprio de cada um desses fenômenos. Dissemos que, no mundo das ocupações, o Dasein foge de si mesmo. Todavia, é o próprio pensador que nos adverte que nem toda retirada ou desvio é fuga. Esta é caracterizada como tal, apenas e somente, na medida em que se fundamenta em algo ameaçador, no medo daquilo que desencadeia o próprio medo. Para o filósofo, aquilo de que se tem medo é sempre algo intramundano e, se assim podemos dizer, sabemos do que temos medo. Na medida em que no mundo da decadência o Dasein foge de si mesmo, aquilo de que foge deve, portanto, possuir um caráter de ameaça. Por outro lado, diferentemente da fuga, o desvio de si mesmo não se funda no medo de algo conhecido. Mas, ao contrário, o ameaçador é algo que tem no seu modo de ser a própria retirada, ou seja, aquilo que se retira tem como próprio de si o velamento, e o que fundamenta esse desvio é a angústia. Isto significa que o "quê" da angústia não é algo intramundano, pelo contrário, é 
indeterminado, não advém e nem transpassa o mundo. Na tonalidade afetiva da angústia, aquilo que ameaça o Dasein se manifesta a partir de uma direção não determinada, vem do nada, de lugar nenhum. Mas, nem por isso, esse lugar nenhum se caracteriza como um nada negativo. É justamente a partir do momento em que o mundo simplesmente dado passa a se constituir como um lugar de total insignificância, lugar em que o mundo se firma apenas em sua mundanidade, é que se dá a abertura para uma outra visada. Voltemos nosso olhar para o poético de modo a encontrar ali algum esteio para o pensar de Heidegger.

Em sua última fase poética, que vai de 1916 até 1935, Álvaro de Campos vive a experiência do limiar, da indeterminação, do vazio. Sua poesia fala de uma existência marcada pela fragmentação interior, pela ausência e pelo nada da dor de existir. É dele que vamos ouvir os célebres versos, escritos em 1934 (um ano antes da morte de Pessoa), sobre a angústia. Tomemos as duas primeiras estrofes:

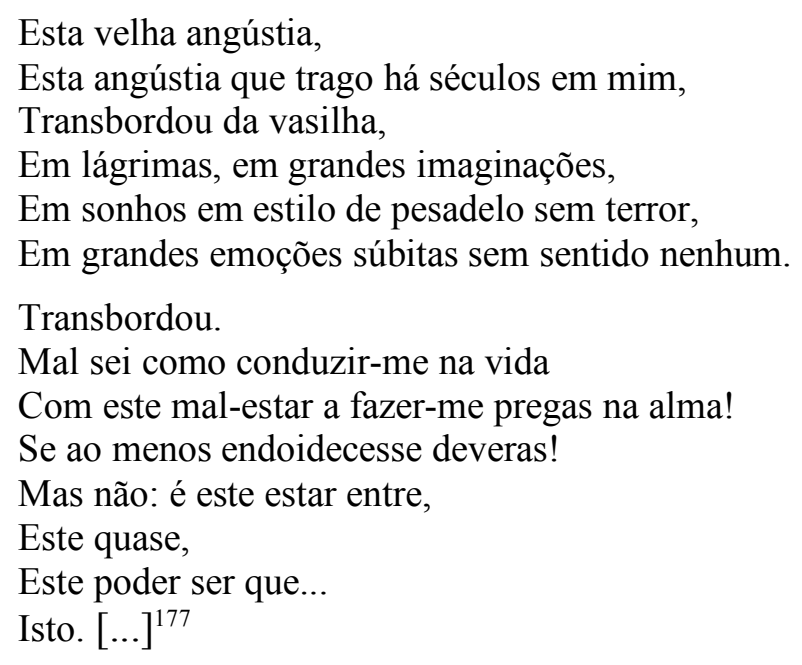

Vemos aqui os matizes do fenômeno originário da angústia através do qual o poeta traduz seu estranhamento diante do mundo que o cerca. De imediato, somos tomados pela noção de que algo muito antigo o acomete. Não se trata de algo novo; estava, como ele mesmo diz, "há séculos em mim". Entretanto, ao que parece, isto que andava adormecido, guardado há séculos, transborda de repente, sai para fora das bordas e deságua em emoções sem sentido, em pesadelo sem terror. Trata-se de uma indiferença total, a qual se põe em relação direta com o fenômeno que se encontra à espreita, à espera exatamente desse transbordamento que, mais cedo ou tarde, se manifesta. Campos nos fala de emoções sem sentido e pesadelo sem terror.

177 PESSOA, Obra Poética, p.390; idem, Obra Completa: Álvaro de Campos, p. 296. 
Imagens que nos remetem a um paradoxo, nos transmitem a noção de algo indeterminado, impreciso, "sem sentido nenhum". O poeta ao lançar uso do oxímoro - que, no grego, oxú-, significa agudo, afiado; e -mōros, ignorante, estúpido $^{178}$, palavras com sentidos contrários que nos remetem à imagens opostas - está a nos falar de algo que é mas não é. Parece-nos que a figura de linguagem rompe com a compreensão semântica exatamente para nos preparar para o que o poeta vai anunciar no verso seguinte: "mal sei como conduzir-me na vida". Este não saber como conduzir-se na vida nos dá a pensar na condição de incerteza, naquilo que rompe totalmente com a familiaridade do cotidiano. Trata-se de uma indefinição, de um poder ser, um quase, um estar entre que é também estranhamento, que é também estar fora de casa, no parado do lugar nenhum da angústia. Ouçamos, ainda, outro verso de Campos a descrever a inderterminação que o estado da angústia traz. Ele diz, em 1928:

Sempre esta inquietação sem propósito, sem nexo, sem consequência, Sempre, sempre, sempre, Esta angústia excessiva do espírito por coisa nenhuma $[\ldots]^{179}$

O fenômeno da angústia também faz morada nos versos de Pessoa. Ouçamos seu lamento, escrito em 1924:
Ah quanta melancolia!
Quanta, quanta solidão!
Aquela alma, que vazia,
Que sinto inútil e fria
Dentro do meu coração!
Que angústia desesperada!
Que mágoa que sabe a fim!
Se a nau foi abandonada,
E o cego caiu na estrada -
Deixai-os, que é tudo assim. ${ }^{180}$

Aqui, encontramos a exacerbação da angústia. O poeta nos revela o desepero da dor sem fim, da alma vazia, da solidão. Descreve-nos o abandono da vida e da indiferença de viver. Entendemos que a velha angústia cantada pelo poeta é a própria confrontação com a vida, com a realidade, sempre a nos lembrar que o fundo da vida é dor, limite e finitude humana. Ouçamos ainda os versos, escritos em 1926, onde o poeta também atenta para o estado da inércia presente na angústia:

\footnotetext{
${ }^{178}$ LIDELL; SCOTT, A Greek-English Lexicon, p. 1235.

179 PESSOA, Obra Poética, p.372; idem, Obra Completa: Álvaro de Campos, p.215.

${ }^{180}$ Ibidem, p.504.
} 
[...] Mas eu, fechado no meu sonho,

Parado enigma, e, sem querer,

Inutilmente recomponho

Visões do que não pude ser.[...]

Mas presa à inércia angustiada

De não saber a direcção,

E ficar morto na erma estrada

Que vai da alma ao coração. [.... $]^{181}$

Trata-se, como vemos, de um estado de imobilidade, uma letargia, um não-ser e um não-saber e a morbidez que estas indeterminações trazem. Octavio Paz, em $O$ arco e a Lira, diz que Baudelaire dedicou inúmeras páginas ao horror que paralisa, petrifica, supende o ânimo e o fluir da vida. ${ }^{182}$ Tal ressonância, encontramos em um poema dramático do Fausto, datado de 1909, que diz:

[...] É o horror dos horrores esse horror

De haver d'alma um estado, aquele estado

Em que o mistério lhe penetra o abismo,

E não haver palavras ou ideias

Que atinjam esse estado ou comuniquem

D'ideias a ideias o que passa

De vago e horroroso. ${ }^{183}$

O trecho relata o mistério do abismo, fala-nos de uma total inacessibilidade, de um lugar em que palavras não conseguem expressar o estado desertificado da alma. Não se trata de uma ameaça, mas, de uma indefinição, de uma indeterminação, de um nebuloso sentimento de pavor trazidos pelo vazio da angústia. As passagens destacadas nos mostram, nas palavras de Campos e Pessoa, que a angústia existencial não tem uma causa intramundana, ela simplesmente os atravessa em uma tal indeterminação que, uma vez instalada, é um caminho sem volta.

No entanto, o mistério e a paralisia presentes na angústia existencial também se mostram como pontes que ligam margens, como possibilidade de ressignificação de mundo, como nos revela esta pequena passagem da "Ode Marítima”, escrita em 1915:

Ah, que essencialidade de mistério e sentido parados

Em divino êxtase revelador

Às horas cor de silêncios e angústias

\footnotetext{
181 PESSOA, Obra Poética, p.508.

182 PAZ, O Arco e a Lira, p.136.

183 PESSOA, Fausto, p.328. Apesar do trecho destacado ter sido previamente editado como pertencente ao Fausto, na edição por nós utilizada, o mesmo encontra-se em anexo. Segundo o editor, o texto pertence a uma seleção de textos sem atribuição.
} 
Não é ponte entre qualquer cais e O Cais! ${ }^{184}$

Apesar do tom soturno, angustiado, da dor e do sofrimento imprimido na ode, vemos nessa estrofe o canto de uma revelação que deságua em uma perspectiva de encontro, onde a figura do cais aqui retratado - grafado em letra maiúscula - aponta para a própria relação do homem com a vida. Notemos que o poeta inicia o primeiro verso com uma espécie de contemplação atravessada por uma sensação de admiração expressa por uma interjeição. Essa sensação nos fala da essencialidade de algo que para o poeta é oculto, mas é também assentamento, uma vez que os sentidos se encontram parados. Entretanto, podemos dizer que se trata de um parado que é também ativo, pois o estado do poeta é de "divino êxtase revelador". De que fala o poeta? Sabemos que se trata de uma revelação, de algo que não é nomeado, apenas sentido. O poeta expressa a sensação trazida pela essencialidade do mistério. Então perguntamos: o que é mistério? E por que o poeta fala de sua essencialidade? Lembremos que o vocábulo mistério - mustếrion do grego e mystērium do latim tem em sua raiz mys- o significado de mística. De um modo geral, o termo mistério significa o estranho, o não compreendido, um enigma de sentido, algo que se reporta a uma inacessibilidade que não esgota em si o seu sentido, pois, via de regra, repousa em uma experiência essencial, sobre na qual não se pode falar, mas devese acolher. ${ }^{185}$ Algo que se mostra e simultaneamente se retira é o traço fundamental do mistério. ${ }^{186}$ Trata-se de um revelar que se mostra na retração e que revela a presença de uma ausência como ausência, ou melhor, um ocultar que se presentifica, mas que não chega ao âmbito do desvelado. Para na linha de ocultação e vê na ocultação, enquanto e como ocultação, mostração. A celebração dessa ausência enquanto e como presença de ausência é a experiência do mistério. Por isso é êxtase divino, o extraordinário no ordinário! Referimo-nos aqui ao atravessamento, à experiência de ser tocado, tomado e, a partir disso, algo vir a ser. Falamos de uma travessia, de um acontecimento que sobrevém ao homem, o qual necessita da angústia e do silêncio para existir - lugar em que o homem é acolhimento e gratidão, lugar em que o homem diz sim àquilo que deve ser guardado e protegido como força da vida. Harada, no escrito Coisas, velhas e novas, também nos fala da vida quando diz que

\footnotetext{
${ }_{184}$ PESSOA, Obra Poética, p.316.

${ }^{185}$ Cf. OTTO, O Sagrado, p.56-63.

${ }^{186}$ Cf. HEIDEGGER, Serenidade, p.25.
} 
no silêncio desse retraimento o mistério é ele mesmo e nada mais, a solidão perfeita da vida. Essa solidão, porém, é o poder, isto é, a possibilidade da vida. Ao se retrair na auto-fidelidade a si mesmo, o mistério se doa inesgotavelmente como exposição do ser, em cujo envio tudo é como vida. ${ }^{187}$

O trecho nos fala da justa medida da vida, de uma consonância perfeita entre o que se deve ser, o que pode ser e o que se precisa ser: o compassamento perfeito da realização de uma possibilidade, do despertar do homem para a sua própria humanidade em sintonia com a vida e com a existência, pois, isto - esta travessia não é a travessia de qualquer ponte, mas a travessia da ponte que liga ao grande Cais da vida, ao torna-te quem tu és, à possibilidade de ser aquilo que já sempre se é, ou seja, inserido autenticamente em um processo de compreensão de mundo se fazendo no próprio mundo que, em última instância, é o próprio ser sendo no mundo.

Como dissemos, o confrontamento trazido pela angústia abre, de forma direta e originária, o mundo como mundo, o mundo em sua plena vigência. Mas resta a pergunta: o que significa mundo ${ }^{188} \mathrm{O}$ que seria esta abertura do mundo em sua plenitude? Ouçamos a palavra de Caeiro, no poema V, de "O guardador de rebanhos", escrito em 1914:

O que penso eu do Mundo?

Sei lá o que penso do Mundo!

Se eu adoecesse pensaria nisso.

Que ideia tenho eu das coisas?

Que opinião tenho sobre as causas e os efeitos?

Que tenho eu meditado sobre Deus e a alma

E sobre a criação do Mundo?

Não sei. Para mim pensar nisso é fechar os olhos

\footnotetext{
${ }^{187}$ HARADA, Coisas, velhas e novas, p.267.

${ }^{188}$ De acordo com Zarader, o vocábulo mundo aparece nos escritos de Heidegger em duas épocas distintas. A primeira vai dos anos de 1935 a 1940 e se refere aos textos consagrados à arte e à poesia, tais como A origem da obra de arte (1935), "Hoelderlin e a essência da poesia" (1936) e "Assim como em dia santo..." (1939), os dois últimos publicados em Explicações da Poesia de Hölderlin. A segunda, diz respeito ao início dos anos de 1950, quando Heidegger retoma a questão da linguagem e da poesia, com os textos: "A coisa" (1950), "Construir, habitar, pensar" (1951), e as conferências de A Caminho da Linguagem (1951 a 1959). (Cf. ZARADER, Heidegger e as Palavras da Origem, p.247-248). Na primeira fase, Heidegger ainda se move no pensamento da diferença entre ser e ente. Portanto, palavras como mundo e terra o ajudam na construção pensante da abertura e fechamento relacionados a um e a outro. Sendo o mundo a própria abertura e a terra aquilo que por natureza se fecha. Um não é sem o outro. São distintos, porém, nunca estão apartados. (Cf. HEIDEGGER, "A Origem da Obra de Arte”, in: Caminhos de Floresta, p.36-58). Na segunda fase, sobre a qual nos atemos nesta trajetória, Heidegger se volta para o vocábulo mundo não para pensálo a partir de uma oposição à terra, mas a partir da manifestação de uma totalidade que contém em si tanto o desvelamento quanto o velamento constitutivo do ser do ente. Nos referimos aqui à dobra entre ser e ente tratada em nossa dissertação de mestrado, intulada "Heidegger e o outro pensar Uma leitura de "Que chamamos pensar?".
} 
E não pensar... É correr as cortinas

Da minha janela (mas ela não tem cortinas). [...]

«Constituição íntima das coisas». . .

«Sentido íntimo do Universo». . .

Tudo isto é falso, tudo isto não quer dizer nada.

É incrível que se possa pensar em coisas dessas.

É como pensar em razões e fins [...]

O único sentido íntimo das coisas

É elas não terem sentido íntimo nenhum. ${ }^{189}$

Os versos do poema $\mathrm{V}$ nos falam de um conjunto de entes presentes à vista? Não! Ao contrário, a compreensão de mundo aqui expressa por certo não se prende ao lugar de manifestação do conjunto de entes ou de um simples aglomerado de coisas que conhecemos ou não, que podemos contar ou não, e que estão presentes em nossa cotidianeidade. ${ }^{190}$ Tampouco dizem respeito a uma cadeida de causas e efeitos. O poeta não quer ter uma opinião sobre as coisas ou mesmo racionalizá-las. Para ele, não há um sentido íntimo das coisas. Pensar sobre isto é "estar doente dos olhos", como ele mesmo diz em outra ocasião. Esta é a doença do mundo: não ter olhos para ver. Caeiro não quer compreender demais, não quer que o mundo seja outro senão o seu mais próprio. Como nos dizem os versos de um poema escrito em 1917:

[...] Nasci sujeito como os outros a erros e a defeitos, Mas nunca ao erro de querer compreender demais,

Nunca ao erro de querer compreender só com a inteligência.

Nunca ao defeito de exigir do Mundo

Que fosse qualquer coisa que não fosse o Mundo. ${ }^{191}$

Então, o que é mundo? Retornemos aos versos de 1914, mais especificamente ao poema VIII:

[...] A Criança Nova que habita onde vivo

Dá-me uma mão a mim

E a outra a tudo que existe

E assim vamos os três pelo caminho que houver,

Saltando e cantando e rindo

E gozando o nosso segredo comum

Que é o de saber por toda a parte

Que não há mistério no mundo

E que tudo vale a pena. $[\ldots]^{192}$

189 PESSOA, Obra Poética, p.206-207; idem, Obra Completa de Alberto Caeiro, p.37-38.

${ }^{190}$ Cf. HEIDEGGER, "A Origem da Obra de Arte”, in:

${ }^{191}$ PESSOA, op.cit., p.240; idem, op. cit., p.98-99. , Caminhos de Floresta, p.42.

192 Ibidem, p.211; ibidem, p.44. Maiúscula do autor. 
Por certo, mundo não é um vocábulo que fala meramente das coisas com as quais nos relacionamos. Caeiro fala a partir de uma outra visada, de um outro olhar trazido pela criança nova que nele habita. Ela é a ponte que liga o velho ao novo. Ela é o elo que liga o poeta ao mundo. Não há um mistério no mundo, o mundo abrange tudo o que é e há. Trata-se daquilo que, segundo Heidegger, Aristóteles nomeou como o vigor daquilo que está na plenitude do seu mais próprio. ${ }^{193}$ Aí nessa dimensão, o real não mais se constitui por medidas ônticas, mas transcende a diferença ontológica e retira do olhar as travas que embotam a plenitude de ser no mundo. A realidade das coisas é capturada por um olhar aberto, sem concepções prévias sobre nada, sem ideias previamente determinadas. Trata-se de um olhar ingênuo, puro, não contaminado, capaz de se espantar e surpreender diante do mundo. É a criança nova que preenche o olhar com a sensação da descoberta. Tudo é novo. Desta "Criança Nova", ele diz:

A mim ensinou-me tudo.

Ensinou-me a olhar para as coisas.

Aponta-me todas as cousas que há nas flores.

Mostra-me como as pedras são engraçadas

Quando a gente as tem na mão

E olha devagar para elas. ${ }^{194}$

Tal olhar somente é possível através de um salto que se direciona ao originário, ao primordial, e indaga pelo sentido de ser. É esta a ultrapassagem proposta nos versos de Caeiro: um estar do mundo que restitui o mundo em sua plenitude, um estar no mundo que permite ver o mundo através de lentes que ampliam o modo de compreender o real. Aí nesse lugar não há separação, mas, apenas, o estar imerso na mundanidade do mundo, abarcados por uma totalidade que reconfigura de modo diverso o nosso estar-já-lançados-no-mundo. Todavia, o gozo e a alegria deste caminhar não são dados a qualquer um - trata-se de um segredo, como ele mesmo diz. O mundo em sua plena vigência, o mundo como mundo, precisa da criança nova para existir. É preciso estar em outro registro! Vemos que o entendimento de mundo aqui trazido vai além de uma compreensão entitativa. Por isso, o mundo não pode se reduzir a uma parte desse conjunto, mas deve abranger a totalidade de tudo que é, ou seja, nos referimos a algo que ultrapassa qualquer medida concreta, material, pois, segue o poeta:

${ }^{193}$ Cf. HEIDEGGER, "Ciencia e Pensamento de Sentido", in: ,Ensaios e Conferências, p.43.

${ }^{194}$ PESSOA, Obra Poética, p.210; idem, Obra Completa de Alberto Caeiro, p.43. 
A Criança Eterna acompanha-me sempre.

A direcção do meu olhar é o seu dedo apontando.

O meu ouvido atento alegremente a todos os sons

São as cócegas que ele me faz, brincando, nas orelhas. [... $]^{195}$

É o dedo da criança eterna que aponta a direção do olhar e que desperta o ouvido do poeta para outros sons. É o habitar da criança divina que transcende a realidade do poeta, transforma o ordinário no extraordinário e faz o poeta ser poesia, uma poesia, como diz Osakabe, "que revela seguir o fluxo cristalino das coisas."196 Caeiro ainda complementa:

E a criança tão humana que é divina

É esta minha quotidiana vida de poeta,

E é porque ele anda sempre comigo que eu sou poeta sempre.

E que o meu mínimo olhar

Me enche de sensação,

E o mais pequeno som, seja do que for,

Parece falar comigo. ${ }^{197}$

Trata-se de um outro modo de ver e ouvir - algo que transcende a cada vez a

totalidade. Referimo-nos a um campo de manifestação que encaminha o poeta para uma abertura de mundo que somente pode ser determinada a partir de um horizonte em que o próprio ser é a medida ontológica para todos os entes. Isto significa que a compreensão de mundo, aqui aventada, somente será ofertada a partir da pergunta fundamental pelo sentido de ser. ${ }^{198}$ Com isso, o mundo e, dentro desse mesmo escopo, a vida só podem ser concebidos a partir do caráter ontológico de ser o seu mais próprio, mas antes é preciso ter o olhar repleto do espanto da criança que se maravilha diante do mundo com uma simplicidade quase pueril. Somente a criança nova "poderia vir em socorro da natureza excessivamente adulta e cansada do homem"199, diz Osakabe. Caeiro confessa:

Como uma criança antes de a ensinarem a ser grande, Sou verdadeiro e leal ao que vejo e ouço. ${ }^{200}$

Entretanto, a cândida lealdade do ver e do ouvir não acontece assim tão fácil, é fruto de um grande aprendizado - é preciso aprender a desaprender. Ouçamos as palavras do mestre:

\footnotetext{
195 PESSOA, Obra Poética, p.211; idem, Obra Completa de Alberto Caeiro, p.44.

196 OSAKABE, Fernando Pessoa: Resposta à Decadência, p.162.

197 PESSOA, op.cit., p.211; idem, op. cit., p.44.

198 Cf. HEIDEGGER, "O tempo da imagem do mundo", in:

${ }^{199}$ OSAKABE, op. cit., p.177.

200 PESSOA, Obra Completa de Alberto Caeiro, p. 124. , Caminhos de Floresta, p.124.
} 
Deito-me ao comprido sobre a terra com erva.

E esqueço tudo quanto me ensinaram.

$\mathrm{O}$ que me ensinaram nunca me deu mais calor nem mais frio.

$\mathrm{O}$ que me disseram que havia nunca me alterou a forma de uma coisa.

O que me aprenderam a ver nunca tocou nos meus olhos.

O que me apontaram nunca estava ali: estava ali só o que ali estava. ${ }^{201}$

Há aqui uma mudança de olhar que fala de um percurso percorrido pelo poeta: esquecer de tudo o quanto ensinaram, desaprender o que aprendeu para poder ver nas coisas as próprias coisas. ${ }^{202}$ Isto significa uma existência demarcada pelo simples deixar a coisa acontecer nela e por ela mesma. Todavia, este deixar a coisa acontecer aponta para uma profunda sabedoria, a qual, segundo Leyla PerroneMoisés, "não consiste em conceituar, mas que está numa vivência inteira do real." ${ }^{203}$ É preciso, pois, deitar sobre a terra como a erva e experimentá-la neste copertencimento para enxergar o mundo através do próprio mundo.

O mundo demarca, assim, a abertura do Dasein em sua existência, a mais pura expressão de ser-no-mundo, a própria abertura do ser: um modo de ser em que o Dasein se abre ao seu mais próprio e percebe que sendo se é. Sabemos, no entanto, que não é essa a forma como nos encontramos no mundo. Em nossa cotidianidade mediana Heidegger diz que o homem, de um modo geral, se previne da angústia, se encobre atrás de uma máscara que não permite que ele se espante diante de si mesmo. ${ }^{204} \mathrm{O}$ que o pensador estaria querendo dizer? Como podemos entender que nosso estar no mundo seja de tal modo impróprio a ponto de usarmos máscaras? O que seria prevenir-se da angústia? E, mais, como a angústia é capaz de tamanha empreitada? São muitas léguas para pernas tão curtas! Voltemo-nos para isso.

\subsubsection{Mergulhando em águas mais profundas}

Como vimos no capítulo passado, o modo como o homem do nosso tempo pensa determina, incontestavelmente, a problematização dessa questão. Presos ao domínio da ciência moderna, nos atemos a resultados teóricos que nos concedem garantias objetivadas do saber, que atuam como fundação e doação de estabilidade,

\footnotetext{
201 PESSOA, Obra Completa de Alberto Caeiro, p. 124.

${ }^{202}$ Cf. PESSOA, Obra Poética, p.217; idem, Obra Completa de Alberto Caeiro, p.56.

203 PERRONE-MOISÉS, Fernando Pessoa: Aquém do eu, além do outro, p.156.

${ }^{204}$ Cf. HEIDEGGER, Ontologia, p.40.
} 
e nos outorgam tão somente um ilusório estatuto de certeza. Subjugados ao tangível da ciência, nos encontramos reféns do domínio técnico que nos interdita e afasta das questões essenciais que falam à nossa alma, às nossas esferas do saber, tais como a arte, a poesia, a língua, a história, a natureza, o homem, Deus. ${ }^{205}$

Cientes de que estamos em fuga de nós mesmos, caberiam aqui as perguntas: o que é abrir-se ao seu mais próprio? O que isto tem a ver com poesia? E mais: o que isto tem a ver com o poeta português? De modo a entrelaçarmos mais alguns fios nesta trama, algum desvio precisa ser feito. Voltemos nosso olhar para um dado importante que merece nossa atenção e nos orienta para uma possível compreensão sobre o fenômeno do outrar-se ${ }^{206}$ pessoano e que pode nos encaminhar para a compreensão do abrir-se ao mais próprio acima mencionado. Lembremos que o nosso caminho se põe à escuta de uma linguagem originária, poética. Neste sentido, nosso desejo também perpassa a busca pelo entendimento das forças que atravessaram o pensar de Pessoa, de modo a acompanhar (se é que podemos fazê-lo) o ensejo de outrar-se. Chama-nos atenção algo bem pontual e característico desse período: a abolição do eu lírico na poesia. Trata-se de uma tendência amplamente divulgada em um documento lançado pelo movimento de vanguarda iniciado por Filippo Tommaso Marinetti, datado de 1913 e intitulado Destruição da Sintaxe - Imaginação sem Fio - Palavras em Liberdade. Nele o autor nos fala:

Meu manifesto técnico opôs o obsessivo $e u$ que até agora os poetas têm descrito, cantado, analisado e vomitado. Para nos livrarmos desse eu obsessivo devemos abandonar o hábito de humanizar a natureza atribuindo-lhe paixões e preocupações humanas a animais, plantas, água e nuvens. $[\ldots]^{207}$

Em uma tentativa de ressignificar a linguagem para além do eu, a poesia futurista se via em contato direto com as sensações trazidas pelas palavras em liberdade que colocavam em questão o jogo da representação. De fato, a poesia, livre da interferência do eu, poderia se orientar por novos impulsos e forças poéticas que, de certa forma, expandiam o gesto artístico e criativo em direções imprevistas, colocando-os em um registro pós-representacional de ideias - lugar em que a poesia

\footnotetext{
${ }^{205}$ Cf. HEIDEGGER, Que chamamos pensar? [inédito], p.31.

${ }^{206}$ Esta forma verbal é usada pelo próprio Pessoa, quando o poeta busca dar entendimento para a heteronímia. Ele diz: "Em prosa é mais difícil de se outrar." (PESSOA, Páginas Íntimas e de AutoInterpretação, p.106).

${ }^{207}$ MARINETTI apud PERLOFF, O Momento Futurista, p.118.
} 
em seu frescor de nomeação se daria na relação com a própria palavra. Em Pessoa não teremos claramente o abandono do eu lírico preconizado pelo futurismo, como vimos anteriormente, atrai-lhe mais a temática do que a estética. Mas ainda que o eu lírico permaneça, algo anterior a isso se dá em uma escala de maior grandeza: a despersonalização literária.

Muitos foram os ecos e reverberações sentidas pelo manifesto de Marinetti. Anos mais tarde, o poeta americano Charles Olson, tematizou a "interferência lírica do ego" como aquela responsável pelos sistemas e lógicas de construções metafísicas, uma interferência que, por se tratar de uma correspondência do real, deveria ser depurada e eliminada em favor da ideia de que o homem é um viajante que compõe a realidade na medida em que nela se insere. ${ }^{208}$ De acordo com Olson, com a saída do ego, entra em cena o corpo. Essa inserção nos fala de uma compreensão também tematizada por Heidegger e poetizada por Pessoa e que será abordada em breve em nosso percurso: a corporeidade - algo que se volta para o fato de que o homem não está apartado da natureza em uma relação sujeito-objeto, como um mero observador, mas, ao contrário, o mundo é incorporado pelo homem ao mesmo tempo que o homem nele se incorpora. Uma outra ressonância quanto à questão do eu é encontrada no texto "La mort de l'auteur", de Roland Barthes, no qual a destruição da voz, a neutralidade do espaço, a perda da identidade e a intransitividade da realidade se colocam como protagonistas nesse processo de aniquilação daquele que escreve. Lembremos também que este é um tempo de dissolução da noção falsamente unitária de sujeito. ${ }^{209}$ Trata-se de uma tendência que já se delineava na França do séc.XIX com Baudelaire, considerado o precursor do Modernismo naquele país, que esboçava o desejo de impessoalidade em suas poesias. Outro escritor que também se volta para a despersonalização lírica é Gustave Flaubert que, em carta endereçada a Louise Colet, de 8 fevereiro de 1852, já escrevia: "Eu quero que não haja no meu livro um só movimento, uma só reflexão do autor." ${ }^{210}$, ou, quando, em correspondência de 26 de agosto de 1853, afirmava: "Nada que diz respeito à minha pessoa me tenta." ${ }^{211}$ Esse eu fragmentado também é famoso na célebre frase de Arthur Rimbaud: "Car je est un autre”, em carta a Paul

\footnotetext{
${ }^{208}$ Cf. OLSON, Human Universe and Other Essays, p.59.

${ }^{209}$ Cf. OSAKABE, Fernando Pessoa: Entre Almas e Estrelas, p.23.

${ }^{210}$ FLAUBERT, Cartas Exemplares, p.57.

${ }^{211}$ Ibidem, p. 125.
} 
Demeny, de 1871. De acordo com Barthes, Mallarmé também já havia antevisto em sua poética que a supressão do autor em favor da escrita recuperava o papel do leitor. Para Barthes, "escrever [...] é alcançar aquele ponto em que somente a linguagem age, performa, e não 'eu'” e quando isso acontece, quando "o autor entra na sua própria morte, a escrita começa"212; algo que ressoa profundamente na célebre frase de Heidegger: "A linguagem fala." ${ }^{13}$ Por certo, não haveríamos de calar nosso poeta para essa questão. Pessoa deixa um manuscrito, escrito em 1915, onde diz:

Não sei quem sou, que alma tenho. [...] Sou variamente outro do que um eu que não sei se existe (se é esses outros). ${ }^{214}$

Trata-se de uma característica bem própria da poética pessoana: o outrar-se, ou como ele mesmo nos faz saber, a heteronímia. Na heteronímia não encontramos exatamente a abolição do eu lírico, uma vez que o eu de cada heterônimo se mantém em suas respectivas líricas, nela encontramos a despersonalização literária do próprio poeta. É Pessoa mesmo que, em carta a Casais Monteiro, escrita em 1935, justifica o nascimento dos heterônimos através de uma tendência nata para a despersonalização. ${ }^{215}$ Todavia, apesar da justificativa atrelada a uma patologia, não é de uma histeria-neurastênica que falamos quando nos referimos à despersonalização literária. Nos atemos a uma autonomia poética, lugar onde o outro que emerge é distinto. Sobre o último grau da despersonalização literária, Pessoa nos dá a saber que o passo final é um poeta que é vários ao mesmo tempo. ${ }^{216}$ Alguns anos antes, por volta de 1930, Pessoa datilografa um prefácio, intitulado “Aspectos”, para a edição projetada de suas obras, onde explica:

[...] O autor humano destes livros não conhece em si próprio personalidade nenhuma. Quando acaso sente uma personalidade emergir dentro de si, cedo vê que é um ente diferente do que ele é, embora parecido; filho mental, talvez, e com qualidades, mas as diferenças de ser outrem. $[\ldots]^{217}$

Em rascunho da famosa carta a Casais Monteiro, Pessoa ainda escreve sobre a despersonalização literária:

\footnotetext{
212 BARTHES, Image-Music-Text, p.142-143.

${ }^{213}$ HEIDEGGER, A Caminho da Linguagem, p. 15.

${ }^{214}$ PESSOA, Páginas Íntimas e de Auto-Interpretação, p.93.

${ }^{215}$ Cf. PESSOA, Obras em Prosa, p.95.

${ }^{216}$ Cf. PESSOA, op. cit., p.107.

${ }^{217}$ Ibidem, p.95-96.
} 
Hoje já não tenho personalidade: quanto em mim haja de humano, eu o dividi entre os autores vários de cuja obra tenho sido o executor. Sou hoje o ponto de reunião de uma pequena humanidade só minha. ${ }^{218}$

Vicente Guedes também nos brinda, no Livro(s) do Desassossego, com um trecho bastante interessante sobre a mesma questão. Ele diz, em "A maneira de bem sonhar nos metafísicos":

Pulverização da personalidade: não sei quais são as minhas ideias, nem os meus sentimentos, nem o meu carácter... Só sinto uma coisa, vagamente a sinto na pessoa visualizada de uma qualquer criatura que aparece em mim. Substitui os meus sonhos a mim-próprio. Cada pessoa é apenas o seu sonho de si-próprio. Eu nem isso sou. ${ }^{219}$

Conquanto apartados espaço-temporalmente, estamos certos de que Baudelaire, Rimbaud, Mallarmé, Flaubert ou Pessoa nos falam exatamente o mesmo: o outramento. Mas, do que falam esses poetas? O que é o outrar-se? Parece-nos claro que este ato poético é permeado por uma certa experiência de "morte" como possibilidade para que algo venha a ser. De imediato, podemos apontar que a "morte" do próprio Pessoa seria a responsável pela gênese de tantos outros. Isto significa dizer que é somente porque Pessoa, ele mesmo, "morre" que os outros podem “nascer". Então, perguntamos: de que fala essa experiência? É sobre ela que desejamos nos ater.

Vimos que a angústia é o lugar em que o mundo se redimensiona, com ela ressignifica-se o intramundano, o estar já-lançado, e, desta forma, abre-se a possibilidade de compreender o seu mais próprio, o seu próprio ser-no-mundo, livre para a possibilidade de ser aquilo que já sempre se é. Nessa compreensão, a angústia torna possível ao Dasein o singularizar-se do seu próprio projeto de possibilidades. Destaquemos a frase - livre para a possibilidade de ser aquilo que já sempre se é e busquemos algum entendimento para ela a partir da sentença de Kierkegaard sobre o conceito de angústia. Não temos por meta uma análise da sentença kierkegaardiana, temos ciência de que o filósofo dinamarquês se prende a uma compreensão intermediada pela fé cristã. Apenas aí buscamos subsídios para a compreensão de um fenômeno tão fundamental no pensamento de Heidegger.

\footnotetext{
218 PESSOA, Páginas Íntimas e de Auto-Interpretação, p. 102.

${ }^{219}$ PESSOA, Livro do Desassossego, p.443; idem, Livro(s) do Desassossego, p.57. Itálico do autor. Talvez pudéssemos estranhar a questão da pulverização da personalidade aqui trazida na voz de um semi-heterônimo, mas lembremos que no capítulo anterior dissemos, em nota, que, por volta de 1917, Pessoa decide passar para Guedes toda a pasta do Livro do Desassossego.
} 
Ademais, sabemos que a análise de Kierkegaard não passou despercebida do pensar do autor de Ser e Tempo. É o próprio pensador que nos fala da escassez de tentativas de interpretação do fenômeno da angústia em uma compreensão ontológicoexistencial, sendo Kierkegaard aquele pensador que mais se aprofundou na análise do fenômeno da angústia. Vejamos o que diz o filósofo dinamarquês: "A angústia é a realidade da liberdade enquanto possibilidade para a possibilidade. ${ }^{220}$ Em uma primeira visada, elencamos as palavras angústia, realidade, liberdade e possibilidade. A partir dessas palavras, podemos, de imediato, intuir que uma realidade se abre com a angústia. Todavia, não entendemos que essa realidade se prenda a uma compreensão já dada, constituída de sentido, algo sobre o qual já tenhamos uma pré-compreensão, pois, a tal realidade que se abre com a angústia é a da liberdade. Além disso, trata-se de uma liberdade enquanto possibilidade para a possibilidade, ou seja, não há garantia de que essa liberdade ocorra, mas apenas a possibilidade de que venha a ocorrer. Podemos, entretanto, dar por certo que Kierkegaard está a nos falar de uma realidade efetiva que se apresenta como uma possibilidade, de uma liberdade que é possível de se tornar realidade a partir da angústia. Entendemos que tal compreensão faz ressonância à ideia de Heidegger de que na angústia o Dasein é livre para a possibilidade de ser aquilo que já sempre é. Mas o que é isso: liberdade de possibilidade de ser o que já sempre se é? Trata-se de uma compreensão primordial, originária e constitutiva do ser do Dasein, a qual existe como possibilidade, como possibilidade de ser. Isto significa que a possibilidade de ser, a qual o Dasein existencialmente sempre é, não é algo já dado ou compreendido pela razão, ou mesmo, de uma contingência lógica, mas, do ponto de vista ontológico, é algo que se apresenta como o existencial mais originário e mais positivo, pois oferta-se sempre como abertura, como poder-ser, como pos-sibi-li-da-de. Não se trata, pois, de um poder-ser qualquer, mas, da "possibilidade de ser livre para o poder-ser mais próprio."221 Mas o que é possibilidade? Entendemos, a partir de Heidegger, que a compreensão fornecida pela lógica e pela metafísica a respeito das palavras possível e possibilidade é sempre dada a partir de uma interpretação do ser como actus e potentia, uma interpretação que se assemelha com a distinção entre essentia e existentia. Sobre estas últimas voltaremos nosso

\footnotetext{
${ }^{220}$ KIERKEGAARD, O Conceito de Angústia, p.45.

${ }^{221}$ HEIDEGGER, Ser e Tempo, p.204. Itálico do autor.
} 
olhar algumas páginas mais à frente. Vejamos agora o que fala o filósofo sobre o poder-ser, sobre o possível. Ele diz, na carta Sobre o Humanismo, escrita em 1947:

Quando falo da 'força silenciosa do possível', não me refiro ao possibile de uma possibilitas meramente representada, nem à potentia enquanto essentia de um actus da existentia. Refiro-me ao Ser mesmo que, querendo tem poder sobre o pensamento e, assim, sobre a essência do homem, o que significa, sobre a referência do homem ao Ser. Poder alguma coisa significa: pre-servá-la em sua essência, con-servá-la em seu elemento. ${ }^{222}$

Entendemos, a partir desse pequeno trecho, que a possibilidade de poder-ser mais próprio diz respeito diretamente ao ser do homem e da relação deste com o ser. Isto significa que o ser mais próprio está atrelado ao querer do ser, graças ao qual, alguma coisa pode ser. O poder é, pois, o próprio possível: aquilo cuja essência firma-se no querer. Dito por outras palavras: é na medida em que o homem escuta o chamado do ser e, através do pensar, se abre em sua direção, que este se torna pleno, ou melhor, é na medida em que o pensar do homem se abre em direção ao ser e com ele forma uma relação de correspondência que o pensar se plenifica. Esse querer é a essência do poder, pois deixa o que é no seu elemento mais próprio. Entretanto, sabemos, através da sentença que abriu esta análise, que a possibilidade de poder-ser o mais próprio está ancorada na angústia. É ela que abre para o Dasein essa possibilidade. Caminhemos um pouco mais.

Cabe-nos ainda pensar a questão da liberdade. O que seria o ser livre? Como poderíamos entender a questão da liberdade na sentença de Heidegger? Não se trata de aqui abarcar a questão da liberdade em toda a sua essencialidade, mas apenas de buscar subsídios para a sentença do filósofo quanto a essa possibilidade. Fazemos notar que toda a questão da liberdade se encontra, de alguma forma, em uma relação essencial com a verdade. Por isso, façamos um pequeno desvio no sentido de recuperarmos algo deste conteúdo. Lembremos que na filosofia dos gregos a palavra verdade era conhecida como alétheia, uma palavra usada na enunciação para expressar certeza e confiança. Esse entendimento foi assumido pela filosofia medieval que condensou na fórmula "Veritas est adaequatio rei et intellectus" toda uma compreensão na qual a verdade é concebida como uma adequação do conhecimento à coisa. Não há nenhuma percepção de que nesse âmbito a verdade reine apenas como adequação e concordância. Como vimos nas páginas iniciais

\footnotetext{
${ }^{222}$ HEIDEGGER, Sobre o Humanismo, p.30. Maiúsculas do autor.
} 
desta parte do capítulo, o círculo iniciado com Platão, cuja a história da essência da verdade é experimentada metafisicamente, se fecha com Nietzsche. No entender de Heidegger, a verdade experimentada como retitude da representação e da enunciação se põe à luz do ente e fica, por isso, reduzida ao sentido de orthótes. A alétheia deve ser entendida como desvelamento, como clareira da presença. Ela não é a verdade. Todavia, a verdade como possibilidade do saber a respeito do ser só pode se dar no aberto da clareira, no desvelamento. A alétheia é, pois, o caminho para o qual o pensamento se abre, é o lugar que possibilita à presença se fazer presente. É ela que possibilita a verdade, é ela que a origina. Esta conexão entre liberdade e verdade, nos levará ao domínio no qual se essencializa originariamente a essência da liberdade. ${ }^{223}$ A liberdade assim compreendida é aquilo que deixa que o ente seja o que ele é. Segundo o filósofo, não há nisso uma omissão ou indiferença, mas, ao contrário, há uma entrega ao aberto que cada um traz consigo. ${ }^{224}$ Referimo-nos aqui ao aberto do desvelar-se, à clareira da presença, à entrega e ao abandono da possibilidade de deixar que algo chegue até nós, nos afete; um espaço onde essa livre dimensão, uma vez contemplada, venha a falar algo tanto do que se faz presente como do que se faz ausente. Não se trata de uma liberdade do homem relacionada às coisas, mas, da liberdade de ser e da liberdade $d o$ ser. Isto significa: uma liberdade concedida pelo homem ao ser e, ao mesmo tempo, uma liberdade concedida pelo ser ao homem - a liberdade de ser na verdade; uma liberdade que se põe no entre do ser e do homem e participa de ambos de modo a articulá-los, como num elo. ${ }^{225}$ Tal liberdade nos remete a uma totalidade que se põe em marcha na existência, na vida, e é determinante para o homem como ser-nomundo. Nesse sentido, a frase de Heidegger: "A possibilidade de ser livre para o poder-ser mais próprio", nos fala de uma disposição, de uma abertura, de uma possibilidade de se existir, totalmente diversa da maneira como habitualmente nos encontramos. Toda essa compreensão se articulará de modo determinante com a questão da experiência fundamental do nada, a seguir, e da transcendência, mais à frente, quando entrarmos na questão da corporeidade.

${ }^{223}$ Cf. HEIDEGGER, "O fim da filosofia e a tarefa do pensamento", in: Os Pensadores, p.105ss. A questão da verdade foi aqui relacionada à liberdade apenas para darmos conta da sentença de Heidegger. No próximo capítulo, voltaremos ao tema da verdade dentro de uma relação direta do homem com a linguagem.

${ }^{224}$ Cf. HEIDEGGER, "A essência da verdade", in:

${ }^{225} \mathrm{Cf}$. ZARADER, Heidegger e as palavras de origem, $\mathrm{p} .72$. Marcas do caminho, p.200. 
Entretanto, antes de darmos mais alguns passos, ainda caberia a pergunta: como entender essa singularização que ocorre com o Dasein na angústia? Haveria aqui algum traço de subjetividade? No $§ 9$ de Ser e Tempo, ao iniciar a analítica existencial do Dasein, Heidegger nos dá algumas indicações para a questão. Ali, o filósofo alemão nos fala que o ser do ente que está em jogo nessa abertura é sempre o seu próprio. E não só isso. O filósofo nos alerta que é da responsabilidade do Dasein assumir seu próprio ser. De imediato, nos deparamos com o fato de que não se trata de uma apreensão que se daria de forma genérica, mas, de uma apropriação que possui um caráter estritamente pessoal. Não é possível, pois, falarmos de uma generalização, de algo que aconteceria com todos e para todos. Não! Exatamente porque é sempre o meu ser que está em questão, exatamente porque essa é uma contenda pessoal, não podemos falar de uma exemplaridade de casos. Uma outra colocação que emerge em relação à singularidade é que, como vimos, a relação do Dasein com o seu ser se coloca sempre como uma possibilidade, um modo de ser que pode ou não acontecer. Isto significa dizer que o Dasein pode ou não se apropriar do seu ser, pode ou não fazer a experiência do seu outro, do outro de si mesmo. Daí a denominação concedida pelo filósofo: propriedade e impropriedade. Apesar de, neste nomear, o pensador nos afirmar que não há um mais ou um menos, mas apenas modos de ser distintos e possíveis ao Dasein, para a questão que nos propomos aqui delinear é importante nos determos brevemente na compreensão do vocábulo eigentlich ${ }^{226}$, que em português ficou traduzido por propriedade. Em alemão, esse termo significa verdadeiro, real, original. Eigen quer dizer próprio, particular, peculiar. Daí advém a noção de próprio, sendo a propriedade o caráter autêntico do Dasein que se apropria de si mesmo. De qualquer forma, reforça-se a ideia de que tanto a propriedade quanto a impropriedade determinam o caráter sempre único, singular, particular e original do Dasein no mundo. Vemos, com isso, que não se trata de um solipsismo existencial, de uma relação subjetiva desprovida de sentido, mas, ao contrário, o poder-ser próprio nos fala de um caráter de singularidade que devolve ao Dasein justamente um sentido extremado de mundo, de vida. Nos sobrevém ainda o questionamento: como isso se dá? Como é possível a angústia ressignificar o mundo?

${ }^{226}$ KELLER, Michaelis, p.86-87. 
Voltemos ao tema da angústia. Agora, ao Livro do Desassossego, onde Vicente Guedes também nos dá a saber o que trata o estado profundo da angústia. Ouçamos a prosa de Guedes:

[...] E assim, sem alegria, mas contente, entre as quatro paredes do meu quarto dorme, por inocência, com o seu pobre papel feio e gasto, toda a angústia insuspeita de uma alma humana que transborda, todo o desespero sem remédio de um coração a quem Deus abandonou. [...]

Separo-me de mim e vejo que sou um fundo dum poço.

Morreu quem eu nunca fui. Esqueceu a Deus quem eu havia de ser. Só o interlúdio vazio.

Se eu fosse músico escreveria a minha marcha fúnebre, e com que razão a escreveria! $!^{227}$

O empregado do comércio também descreve o sentimento de abandono presente na angústia. De pronto, fala-nos de um paradoxo: da angústia que dorme "sem alegria, mas contente" entre as quatro paredes do seu quarto. Mais uma vez, chama-nos atenção o uso do oxímoro, algo bastante recorrente na poesia pessoana e característico da estética modernista, que parece nos jogar em uma contradição ou mesmo em uma indeterminação. Afinal, como pode algo sem alegria ser, ao mesmo tempo, contente? Na realidade, o recurso da figura de linguagem acaba por reforçar a ideia de uma incerteza, de um sentimento dúbio presente no autor - a própria angústia - que, "feia e gasta", transborda do coração abandonado por Deus. Guedes descreve a imagem do poço sem fundo da angústia, lugar em que ele reconhecidamente se encontra. Fala-nos de sua desconexão com o mundo, de alguém que morre sem nunca ter sido, do oco da vida. Conta-nos do vazio e da dor de existir.

O famoso texto "A floresta do alheamento", escrito em 1913, também nos fala do torpor, da incerteza, do alheamento da vida trazidos pela angústia. Ouçamos, uma vez mais, a voz de Guedes a narrar poeticamente o lamento deste momento:

[...] Um vento de sombras sopra cinzas de propósitos mortos sobre o que eu sou de desperto. Cai de um firmamento desconhecido um orvalho morno de tédio. Uma grande angústia inerte manuseia-me a alma por dentro e, incerta, altera-me, como a brisa aos perfis das copas.

$\mathrm{Na}$ alcova mórbida e morna a antemanhã de lá fora é apenas um hálito de penumbra. Sou todo confusão quieta... Para quê há-de um dia raiar?... Custa-me o saber que ele raiará, como se fosse um esforço meu que houvesse de o fazer aparecer. $[\ldots]^{228}$

\footnotetext{
${ }^{227}$ PESSOA, Livro do Desassossego, p.363; idem, Livro(s) do Desassossego, p.161-162.
}

${ }^{228}$ Ibidem, p.454; ibidem, p.48. 
As sombras, as cinzas e os propósitos mortos sopram a indeterminação da angústia sobre Guedes. Suas palavras relatam a quieta indiferença a tudo que o cerca e à própria vida que se ergue com o raiar do dia. Seu estado é o da total apatia.

Em outro fragmento do livro, Bernardo Soares que, como vimos, é o especialista em tédio, também se detém na incerteza da angústia quando diz:

[...] Um desespero de mim, uma angústia de existir preso a mim extravasa-se por mim todo sem me exceder, compondo-me o ser em ternura, medo, dor e desolação.

Um tão inexplicável excesso de mágoa absurda, uma dor tão desolada, tão órfã, tão metafisicamente minha. ${ }^{229}$

Soares sente-se tomado por completo pelo estado da angústia. Fala-nos do desolamento de algo inexplicável e do sentimento de orfandade e desamparo trazidos por isto que o acomete. As palavras do guada-livros também reverberam o parado da angústia, o lugar da indiferença, da resignação, da inércia e do vazio da vida, quando diz:

No meu coração há uma paz de angústia, e o meu sossego é feito de resignação. Passa tudo isso, e nada de tudo isso me diz nada, tudo é alheio ao meu sentir, indiferente, até, ao destino próprio, inconsciência, círculos de superfície quando o acaso deita pedras, ecos de vozes incógnitas — salada colectiva da vida. ${ }^{230}$

Trata-se, como vimos, do estar "estranho" característico da angústia que diz respeito à indeterminação do nada e do lugar nenhum; uma estranheza que nos direciona diretamente ao "não se sentir em casa", algo que rompe com a familiaridade do cotidiano e nos remete ao estranho mundo da coisa nenhuma, um lugar que não necessita precisamente da escuridão para existir. Heidegger enfatiza que a angústia se apresenta como uma disposição ontológico-existencial fundamental, ela é constitutiva do Dasein como ser-no-mundo, e, nesse caso, o "não se sentir em casa" deve ser compreendido como o mais originário. Apesar da angústia originária ser um fenômeno bastante raro, essa originariedade não impede que a mesma possa ser compreendida como um princípio para uma analítica existencial. Ao contrário, a singularidade do fenômeno torna-se um indicativo de que não só o Dasein permanece encoberto em sua propriedade, mas, sobretudo, que é a disposição da angústia a possibilidade de abertura de um sentido originário, o qual libera o Dasein para ser o seu mais próprio.

\footnotetext{
${ }^{229}$ PESSOA, Livro do Desassossego, p.419; idem, Livro(s) do Desassossego, p.457.

${ }^{230}$ Ibidem, p.50; ibidem, p.252.
} 
Vê-se, a partir disso, que o que está em jogo na angústia é a abertura para uma compreensão que descortina o olhar para um outro modo de estar no mundo, para um outro modo de existir. Fato que nos leva, de imediato, para aquilo que Heidegger compreende por existência, pois, para ele, existência expressa não só um poder-ser, mas sobretudo um poder-ser próprio. ${ }^{231}$ Para o pensador, enquanto o poder-ser próprio não se incorporar à ideia de existência, a compreensão de existência fica comprometida e se privará de originariedade. Sabemos que o modo de ser do homem é o de existir. A primeira consideração que emerge dessa afirmação é a de que o Dasein se caracteriza pela condição de ter um ser e que este, na medida em que dele podemos falar, deve ser compreendido a partir de sua existência. Com isso, faz-se necessário o entendimento da palavra existência no vocabulário heideggeriano. Devemos, primeiramente, enfatizar que esse termo não pode, de forma alguma, se aproximar daquilo que a tradição entendeu por existentia. As diferentes maneiras concebidas para esse vocábulo diferem apenas aparentemente e têm em vista somente a realidade efetiva. Ao anunciar o primado da existência sobre a essência, o filósofo quer expressar que é no homem que o seu ser se essencializa. É no homem que se dá a verdade de sua essência. Para o pensador, a essência do homem - aquilo que o homem é - está na sua existência. Ao declarar que o traço fundamental do homem em sua humanidade é ser-nomundo, o filósofo não está afirmando que ele é apenas do mundo, um ser para o qual não se abre a transcendência. $\mathrm{O}$ mundo de ser-no-mundo não se opõe ao celeste, e, nem tampouco, diz respeito ao ente. Como vimos, mundo significa a abertura ao ser. Portanto, nos referimos aqui ao homem que vive a experiência da transcendência na imanência.

No sentido de meditarmos sobre essa dimensão, é necessário primeiro entendermos com clareza como é que o ser se direciona ao homem e como o convoca. Esta compreensão só é possível a partir de uma experiência essencial que nos será outorgada, na medida em que compreendemos que o homem só é enquanto existe. Na linguagem da tradição, aquilo que está no fundo de nossa existência, aquilo que a sustenta e determina, é denominado substância, mas, de acordo com o filósofo, a substância pensada pela tradição possui uma ambiguidade, pois o termo grego ousía ora nomeia a presença do que se apresenta, ora visa a própria coisa que

${ }^{231}$ Cf. HEIDEGGER, Ser e Tempo, p.305. 
se apresenta. Essa ambivalência acabou por desviar a frase "a 'substância' do homem é a existência", citada inúmeras vezes em Ser e Tempo, da acepção pensada por Heidegger. Ali, a destruição fenomenológica já estava em curso e, por isto, o termo adquire o significado de: "o modo como o homem se apresenta em sua própria essência ao ser é a ek-stática in-sistência na verdade do ser." ${ }^{232}$ A frase parece não nos esclarecer muito! Guardemos a sentença enigmática, para, logo a seguir, buscarmos algum esclarecimento. Por ora, podemos adiantar que se trata de um divisor de águas. É a partir dessa compreensão que Heidegger declara que qualquer afirmação sobre subjetividade deve ser banida, pois o homem nunca é primeiramente sujeito, um sujeito que pensa o eu em uma constante relação com o objeto. Mas, ao contrário, o homem, antes de estar do lado de cá do mundo, existe na abertura do ser. É por isso que quaisquer rotulações sobre a essência do homem, tais como animal racional, sujeito, ser dotado de alma, corpo e espírito não são falsas, mas, tardias e não correspondem àquilo que a essência do homem quer imprimir. Retomemos a pregunta: $\mathrm{O}$ que seria esse modo como o homem se apresenta em sua essência? O que seria essa in-sistência ek-stática na verdade do ser?

Em 1949, Heidegger retoma a questão da existência na introdução ao texto “Que é Metafísica?". Ali, o pensador nos diz que a in-sistência ek-stática na verdade do ser diz respeito a uma abertura para o próprio ser que se mantém e sustenta. Todavia, permanece a dúvida: como pode uma essência se manter e sustentar? Para o pensador, não é possível uma formulação adequada para a essência ekstática da existência uma vez que a mesma é sempre pensada a partir de algo que está fora da interioridade do homem. Todavia, esse fora é paradoxalmente a própria abertura para o dentro, para o próprio ser, e forma, nessa dimensão, uma unidade de uma mesma presentificação. Mas, como podemos entender a univocidade desse acontecer? Nos referimos a um acontecer que é dado, apenas e tão somente, ao homem, pois somente ao homem é dada a in-sistência ek-sistente do desvelamento do ser. A partir dos vocábulos in-sistência e ek-sistente, podemos perceber uma sinalização da intencionalidade do filósofo em demarcar a dinâmica dentro/fora anunciada a partir da hifenização dos prefixos in- e ex-, respectivamente. Sendo o prefixo in- relacionado a uma interioridade e o ex-, à ideia de uma abertura, de uma

${ }^{232}$ HEIDEGGER, "Sobre o "Humanismo", in: , Os Pensadores, p.355. 
exterioridade. ${ }^{233}$ Trata-se, portanto, de um movimento que se caracteriza por um fora e um dentro, na medida em que matém-se na insistência. Todavia, esse fora não é fora do homem, e o dentro, tampouco uma interioridade introjetada na mente, mas diríamos que se trata de um entre que acontece na relação do homem com o mundo. Com isso, a ek-sistência, a abertura do homem para o ser, fica singularizada por esse modo próprio da in-sistência: uma sustentação em direção à verdade do ser. Daí a constatação de que somente o homem existe, pois somente o homem é capaz de fazer esse movimento de permanência em direção ao ser. É assim que Heidegger entende a transcendência, como veremos mais adiante. E mais! Com o intuito de caracterizar que esse movimento nada tem a ver com a consciência, o filósofo afirma que não é a consciência de si mesmo que possibilita essa abertura para o ser, nem, tampouco, é ela que determina a existência do homem. A consciência de si mesmo enuncia apenas uma compreensão daquilo que o homem é enquanto homem. Portanto, além de tardio, fica claro que o escopo da consciência se estende à dimensão do ente e não àquela da verdade do ser do ente. Com esse desvio, entendemos que fica demarcado o que seja existência para o pensador alemão. Retomemos, agora, o passo em direção à angústia originária.

\subsubsection{O nada que é tudo}

Como vimos anteriormente, a originariedade orientadora de analítica existencial deve incorporar à ideia de existência o poder-ser próprio. De acordo com Heidegger, este é um saber que não é dado por um entendimento sobre si mesmo, mas, copertence ao Dasein. É exatamente porque existencialmente o Dasein se compreende como essa possibilidade que ele pode perder-se de si mesmo e encontrar-se a si mesmo, ou seja, existe sempre a possibilidade do aberto, do poderser próprio. Tal compreensão deve ser entendida como o despertar do Dasein para si mesmo. ${ }^{234}$ Isto significa que o aberto dado por esse entendimento libera o Dasein para seu mais próprio, para as suas possibilidades de ser. E não só isso! Essa compreensão possui uma estrutura existencial, a qual constitui o espaço de

\footnotetext{
${ }^{233}$ Cf. ERNOUT, MEILLET, Dictionnaire Etymologique de la Langue Latine, p.204 e 312, respectivamente.

${ }^{234}$ Cf. HEIDEGGER, Ontologia, p.21. Itálicos do autor.
} 
articulação com a própria vida. Por outras palavras: Heidegger nos fala de uma compreensão originária e constitutiva que se dá no sendo do Dasein, em seu habitar no mundo, que acontece antes mesmo que a consciência possa ali pousar, pois, como vimos, qualquer teoria que busque explicar o homem em sua existência é posterior àquilo que se dá na abertura ao mais próprio do Dasein. Estamos aqui circunscritos à uma relação existencial com as coisas; lugar que, enquanto possibilidade para possibilidade, deixa ser o mais próprio de cada coisa. Falamos de uma compreensão em que o Dasein se relaciona com o mundo de forma a dar sentido a ele, e, em assim procedendo, dá sentido a si próprio. Todavia, ainda permanece a pergunta: na medida em que nossa cotidianidade mediana diz respeito à vida e esta se constitui por estar entre o nascimento e a morte, não deveríamos nos ocupar também de algo que ainda não é?

Aquilo que se acha no porvir e, portanto, pendente é o próprio fim, a própria morte. Entretanto, na maior parte do tempo, nem cogitamos essa possibilidade, ou seja, a morte não tem para nós um sentido próprio, ela se põe como inacessível à experiência. Vivenciamos a morte dos outros, mas não a nossa! Apesar de não ser dada à experiência, a morte é constitutiva, ou seja, faz parte de nossa existência essa concretude. A morte, que só pode ser pensada em seu caráter existencial, é, por assim dizer, o ser-para-o-fim e, assim sendo, ela é a possibilidade do homem não mais ser-no-mundo. É exatamente a compreensão da finitude que vai assumir o caráter de poder-ser mais próprio do homem. Com a morte, estamos circunscritos ao imponderável, ao inexorável, ao intransponível. Esta impossibilidade é a característica mais própria de poder-ser, e o ser-para-o-fim, a possibilidade mais privilegiada. Trata-se, pois, da "possibilidade de uma impossibilidade", da impossibilidade de existir. Com a compreensão desta finitude, abre-se um modo de ser, uma possibilidade em que o homem pode ser pleno, todo, completo, si próprio, autêntico. É, pois, a antecipação dessa compreensão que aproxima o homem da possibilidade de existir em sentido mais próprio, assumindo em sua singularidade de ser, a partir de si mesmo e para si mesmo, o modo mais extremado. Por outras palavras: na medida em que o homem compreende antecipadamente que o nãopoder-ser se põe em seu horizonte e que a morte delimita a sua existência, essa compreensão autêntica e projetada de um si mesmo finito abre e intensifica de forma determinante a experiência de um poder-ser em sua totalidade, um poder-ser 
próprio. Segundo Heidegger, o que libera o Dasein para essa compreensão é essencialmente a angústia. ${ }^{235} \mathrm{E}$, pois, esse perder-se de si mesmo, que a compreensão da finitude presente na angústia traz que reconfigura o ser-no-mundo. É o perder-se de si mesmo que assegura e legitima a possibilidade da totalidade do ser-próprio. Inserido nisto está o ser-para-morte que nos fala de finitiude, mas, também da morte existencial presente na angústia originária. Acompanhemos o pensamento do filósofo sobre o desenvolvimento da questão, presente na preleção “Que é Metafisica?”, de 1929, assim como, nos escritos posteriores que a complementam, o posfácio e a introdução, de 1943 e 1949, respectivamente, quando veremos o adensamento da questão. Vejamos como isso se dá.

Heidegger nos fala que é com a disposição da angústia que se abre para o Dasein a compreensão de uma existência finita e, com ela, a liberação para o poderser mais próprio, para o outro de si mesmo. Na angústia, o ente, que cada vez nós mesmo somos, vê-se lançado para além de si mesmo. Suspenso no lugar nenhum da angústia, em total estranheza e indiferença, o ente se ausenta. Segundo o filósofo, da ausência do ente em sua totalidade, manifestada na angústia como suspensão de si mesmo, resta o vazio, o nada. Todavia, o nada não é a ausência de todas as coisas, esse nada não é um nada, não é uma negação, não se trata de um niilismo como aquele tratado no capítulo anterior, ao contrário, falamos aqui de uma plenificação, de um nada que é tudo, de um nada que é o próprio ser. Referimo-nos a um nada que é a condição de possibilidade do exercício da totalidade. É, pois, preciso o nada para se gerar o todo. Interessante notarmos, através do texto "Ipseidade, angústia e autenticidade", de Luiz Bicca, que, comparativamente a Ser e Tempo, o estatuto ontológico do nada se amplia no escrito “Que é metafisica?”. Segundo o intérprete, neste escrito, o nada se direciona ao ser do ente na totalidade. A angústia originária se move cada vez mais em relação ao ser e aprofunda, de modo incontestável, a própria relação do homem com o nada que o possui. O que se impõe a partir daí é que, ancorado ao nada, o homem faz a experiência do ser. Por isso, o nada não pode jamais ser pensado como uma nulidade ou desprovido de sentido, ao contrário, é a partir do nada que se abre a possibilidade de experimentarmos o próprio ser. ${ }^{236}$ Isto significa que o nada - o não-ente - é o desdobramento do absolutamente outro com

${ }^{235}$ Cf. HEIDEGGER, Ser e Tempo, p. 343.

${ }^{236}$ Cf. BICCA, O Mesmo e os Outros, p. 31 . 
relação ao ente que se desdobra como $\operatorname{ser}^{237}$ Aí, não há linguagem capaz de expressar o é. A palavra se cala em um silêncio profundo diante da presença do nada. Com este acontecimento, podemos afirmar que é com a tonalidade afetiva fundamental da angústia, na qual o nada se manifesta, que o Dasein atinge o seu acontecer. Mas, logo interrogamos: o que é o estar suspenso no nada? A voz de Bernardo Soares ressoa com aguda clareza à pergunta sobre a experiência do nada quando, no "Livro dos Viajantes", diz:

[...] Pouco a pouco vou perdendo a consciência nítida de que existo coextensamente com isto tudo, de que realmente me movo, ouvindo e pouco vendo, entre sombras que representam entes e lugares onde entes o são. [...]

Nestes momentos de terror supremamente silencioso não sei o que sou materialmente, o que costumo fazer, o que me é usual querer, sentir e pensar. Sintome perdido de mim mesmo, fora do meu alcance. [...] Sinto-me apenas um vácuo, uma ilusão de uma alma, um lugar de um ser, uma escuridão de consciência onde estranho insecto procurasse em vão sequer a cálida lembrança de uma luz. ${ }^{238}$

A descrição fala da suspensão de mundo, da perda de si mesmo, da perda de todos os referenciais que cercam Soares. Não há sequer o rastro de uma compreensão entitativa das coisas. O guada-livros conta do silêncio, da vastidão de um lugar sem nome, sem medida. Ele não sabe quem é, o que faz, o que quer, o que sente, o que pensa. Sente apenas a sombra da existência, a noite da alma, a escuridão do nada. Pessoa também nos afirma a nadidade que a angústia traz nos versos escritos em 1923:

Nada sou, nada posso, nada sigo

Trago, por ilusão, meu ser comigo

Não compreendo compreender, nem sei

Se hei de ser, sendo nada, o que serei. ${ }^{239}$

Os versos do poeta expressam profundamente o não saber, o não compreender e o nada. Há aqui a nomeação de uma nadificação que ressoa muito claramente no estar suspenso dentro do nada, na suspensão de todos os referenciais que o nada traz. Hühne, em $O$ Poetar Pensante, diz que "não há dúvida que esse nada é proveniente da experiência de quem suporta viver o estado da angústia [...] onde a existencialidade não tem mais sua dimensão familiar e aparece de modo inequívoco, o abandono original da existência." ${ }^{440}$ Trata-se do nada, do lugar

${ }^{237}$ Cf. HEIDEGGER, "Que é Metafísica?", in: Os Pensadores, p.69.

238 PESSOA, Livro do Desassossego, p.224; idem, Livro(s) do Desassossego, p.343. Quanto ao , o símbolo se refere ao espaço em branco deixado por Pessoa, no original.

${ }^{239}$ PESSOA, Obra Poética, p. 145.

${ }^{240}$ BERARDINELLI et alii, Fernando Pessoa e Martin Heidegger: O Poetar Pensante, p.154. 
nenhum do oco da vida - da compreensão de que não se é nada. Não há, entretanto, uma aniquilação total, no nada reside a ânsia da vida, o vazio pleno de possibilidades. Algo que, em 1928, Campos já teria proclamado nos primeiros versos de "Tabacaria":

Não sou nada.

Nunca serei nada.

Não posso querer ser nada.

À parte isso, tenho em mim todos os sonhos do mundo. ${ }^{241}$

O que é o não ser nada aqui expresso com tamanha radicalidade? Entendemos esses versos como um salto que a vida dá para dentro dela própria, um salto que revela o abissal como abissal e, assim procedendo, revela o limite e a radical impossibilidade de ultrapassar esse limite - o nada que é também a própria plenitude, o todo que a vida pode ser. Não se pode querer ser nada além disso. Há nessa pobreza uma grande riqueza, aqui se dá o pleno, o extraordinário no ordinário. É exatamente neste nada que o todo aparece, é exatamente neste nada que um campo de infinitas possibilidades se abre e o poeta tem si "todos os sonhos do mundo". Falamos de uma espera e de uma escuta, as quais se desdobram em abertura - lugar em que a obra se apropria do apropriável. Não é somente quando isso acontece que é possível se contemplar o grande fluxo da vida? Aquilo que enquanto possibilidade para possibilidade deixa ser o mais próprio de cada coisa? E não é somente quando o poeta se deixa tomar por essa possibilidade que ele é poeta? Trata-se, pois, de um assentar-se, um aquietar-se, somente possível a partir da angústia originária, do nada, os quais, ao atravessarem o poeta em uma inaudita indeterminação de nada ser, são pontes que unem margens, desvelam o totalmente outro que se encontrava velado: o próprio ser. Ouçamos o terceto cantado por Pessoa, em 1934:

Agora o seu ser ausente,

Surge o que há de presente

$\mathrm{Na}$ ausência eternamente. ${ }^{242}$

A passagem acima destacada nos fala de uma presença que irrompe a partir de uma ausência, que, contudo, não chega ao âmbito do desvelado, permanece eternamente como uma ausência transpassada pela presença que surge. Isto significa que no espaço que se abre é indissociável a luz e a sombra, o sim e o não, uma totalidade que é também nenhuma, um nada que é tudo, a plenitude de uma ausência permeada

${ }^{241}$ PESSOA, Obra Poética, p.362.

${ }^{242}$ Ibidem, p.573. 
por uma presença. Berardinelli nos fala, em Fernando Pessoa: Outra vez te revejo...: "para essa eterna presença da ausência, que surge quando o ser está ausente, é que ele todo se volta, convicto de que ela é o seu mito, 'o nada que é tudo'[...]." ${ }^{243}$ Ricardo Reis nos brinda com uma linda ode, escrita em 1933, que nos oferece exatamente a compreensão que desejamos transmitir. Ouçamos os versos:

No fim tudo será silêncio, salvo onde o mar banha nada. ${ }^{244}$

Trata-se de pensarmos aqui na própria experiência da vida como finitude e toda a possibilidade que isso traz. Encontramos em alguns intérpretes análises para este trecho da ode que nos ajudam a pensar o nada. Segundo Lourenço, "o acto nadificante tem em Reis a sua elegia." 245 Isto significa que o tom épico da ode, ainda que envolto por um tom melancólico e triste, normalmente presente nas elegias, encontra no nada a sua força motriz. É exatamente onde o mar banha nada, onde nada há, a partir da mais absoluta experiência do silêncio, que se abre a possibilidade de tudo ser. Para Seabra, os versos exprimem luminosmante a identificação dos contrários. A oposição entre o silêncio de tudo e o não silêncio de nada, é quebrada pela introdução da preposição "salvo", a qual cria um nexo fundante entre as estruturas. Ele diz: “o não silêncio de nada não é na verdade já inerente ao não silêncio de tudo?"246 A essencial equivalência entre os termos cria uma consubstanciação absoluta, que tanto pode "reportar-se ao puro Não-Ser como à totalidade do Ser."247 Segundo o intérprete, trata-se de uma coexistência que a linguagem poética pessoana busca conciliar. Sobre isto, Jacinto Prado Coelho ainda acresentaria: "a identificação paradoxal dos termos polarmente opostos - tudo, $n a d a$ - integram-se num dos aspectos que melhor definem o estilo de toda a obra de Pessoa [...]." ${ }^{248} \mathrm{O}$ autor se refere à capacidade que Pessoa tem de criar uma unidade entre termos opostos, através de uma inteligência crítica que une inspiração e sensibilidade.

Caminhemos um pouco mais, com as seguintes perguntas em mente: como pode o ser nada desdobrar-se no ser si mesmo? Como pode o nada ser tudo? Como

\footnotetext{
243 BERARDINELLI, Fernando Pessoa: Outra Vez te Revejo..., p.48.

244 PESSOA, Obra Poética, p.291; idem, Obra Completa de Ricardo Reis, p.175.

${ }^{245}$ LOURENÇO, Pessoa Revisitado, p. 83.

246 SEABRA, Fernando Pessoa ou o Poetodrama, p.57.

${ }^{247}$ Ibidem, p.53.

${ }^{248}$ COELHO, Diversidade e Unidade em Fernando Pessoa, p. 166.
} 
pode o nada se desdobrar no ser? Entendemos, com Heidegger, que essas são perguntas envoltas por uma certa complexidade, pois, se por um lado, a ciência reconhece o nada como algo que não existe, por outro, mantendo-nos no apelo à questão, é certo admitirmos que a pergunta - o que é o nada? - já antecipa algo que $e ́$, já traz em si uma carga semântica, significa algo. Sabemos de antemão que o nada não é o ente e que dele se diferencia. O problema é que a pergunta pela essência do nada lança-o para o seu inverso, para algo que é de algum modo, nos mesmos moldes de um ente. Essa contradição interna já impossibilita a própria interrogação e, consequentemente, uma resposta. Além da ciência, o princípio da não-contradição também nos inviabiliza o questionamento, que seguindo uma lógica universal interdita a questão. Entretanto, o pensador alemão nos diz que podemos nos aproximar do nada através do entendimento de que o nada é simplesmente o não-ente e deve ser compreendido como uma exigência da própria negação. Ora, se o nada existe a partir de uma negação e a negação é um ato do entendimento, o filósofo está certo de que o nada é anterior e mais originário do que a negação. É, pois, a permanência na questão que nos levará a cumprir uma necessidade básica para a elaboração de qualquer entendimento. Já conhecemos o nada como a plena negação da totalidade do ente. Isto é um indício do caminho que devemos seguir: torna-se necessário que a totalidade do ente seja conhecida, para que a partir de sua negação possa o nada aparecer. Mas, como tornar visível a totalidade do ente em sua plenitude? Para o filósofo a busca do nada só pode ser "legitimada por uma experiência fundamental do nada." ${ }^{249}$ Por ora guardemos essa última frase para, mais adiante, retornarmos a ela. Sigamos os passos de Heidegger um pouco mais.

O filósofo nos coloca, então, uma advertência: a grande dificuldade de compreendermos o ente em sua totalidade. Como vimos, em nossa existência nos encontramos em meio ao ente; ora vagando, ora atrelados a uma de suas dimensões; ora de modo próprio, ora de modo impróprio. Ainda que dispersos em nossa cotidianidade, o ente permanece em uma unidade de totalidade. O pensador entende que justamente no momento em que nos ausentamos das coisas e de nós mesmos, quando adentramos o abismo da angústia, diante desse limite que beira a aniquilação, quando o ente em todas as suas determinações se retira, é justamente

${ }^{249}$ HEIDEGGER, “Que é Metafísica?”, in: ,Os Pensadores, p.55. 
aí que temos a possibilidade de sermos lançados a uma compreensão dessa totalidade. É a angústia que silenciosamente nivela tudo em uma inaudita estranheza e indiferença que acaba por manifestar o ente em sua totalidade. Faz-se, pois, necessária uma tonalidade afetiva originária para o nada aparecer, e esta é a angústia, que se diferencia de imediato de todas as outras disposições de humor, tanto por atravessar o homem com uma imponderável tranquilidade, quanto por se manifestar em uma essencial indeterminação. Ao arremessar o homem para além de si mesmo, suspenso no lugar nenhum, o ente se ausenta.

Vemos, com isso, que o nada que se revela na angústia não é um ente objetivado, não há na angústia um entendimento do nada. O que acontece é um manifestar-se do nada em meio ao ente em sua totalidade. Entendemos que a opressão e o desamparo aos quais o ente é lançado pela angústia não o destrói por completo, não há uma perda total de si mesmo. Neste processo, o ente em sua totalidade retrai-se de tal forma e o que resta é apenas o nada em sua essência: a nadificação. Para Heidegger, o nadificar do nada age de forma a trazer à luz o outro que se encontrava velado, manifesta o absolutamente outro. Vemos aqui um desvelar-se, somente possível pela originária abertura gerada pelo nada da angústia. Em outras palavras: o nada da angústia dá origem ao encontro do homem com o seu outro, o seu mais próprio, pois somente com a emergência da possibilidade do nada é que esse outro pode mostrar-se em seu ser. Portanto, o nada não é um nada, um vazio sem significado ou uma negação. Ao contrário, vemos com Heidegger que

em vez de cerdemos a esta pressa de uma perspicácia vazia e sacrificarmos a enigmática multivocidade do nada, devemos armar-nos com a disposição única e experimentarmos no nada a amplidão daquilo que garante a todo o ente (a possibilidade) de ser. Isto é o próprio ser. ${ }^{250}$

Suspenso dentro do nada, o Dasein está além do ente em sua totalidade. A este estar além, que é determinado pela in-sistência ek-stática da existência humana, o filósofo nomeia transcendência, a única possibilidade de, através do nada, o poder-ser mais próprio e a liberdade existirem. Sendo a experiência fundamental do nada originária do encontro do ser do homem com o ente em sua totalidade, indagamos: por que o nada originário não se revela em sua origem? Por que, apesar

${ }^{250}$ HEIDEGGER, “Que é Metafísica?”, in: , Os Pensadores, p.69. 
de estar sempre à espreita, a angústia originária é rara? De acordo com o pensador, a angústia originária dorme no Dasein e mais cedo ou tarde, aleatoriamente, a velha angústia, cantada por Campos, se manifesta de forma a arrastar à suspensão do nada a finitude do Dasein; e é aí que vivemos a mais simples experiência da liberdade. Com a suspensão do ente em sua totalidade originado pelo nada da angústia originária chegamos à transcendência, ao ultrapassamento do ente na totalidade, ao estar retido no nada, que, em última instância, é a própria abertura para o ser.

Voltemo-nos agora para uma palavra que, em nossa opinião, possui um estatuto bastante elevado no vocabulário heideggeriano: trata-se do vocábulo experiência. Cientes de que deixamos inúmeras pontas soltas sobre esta questão, façamos um esforço para amarrá-las. Vimos insistentemente falando que a angústia originária é a tonalidade afetiva que pode reconduzir o homem ao seu mais próprio e que esse reenvio é fruto de uma experiência. À que a palavra experiência nos remete? Estaríamos aqui nos referindo ao método indutivo da experiência e analogia? Por certo não nos atemos aqui àquela experiência orientada pelo escopo da ciência, que se dá a partir da investigação de coisas singulares e da regularidade com que as mesmas se manifestam, tal como Aristóteles que concebia o termo empeiría a partir da observação das coisas e de suas propriedades no sentido de regular e determinar o modo como se comportavam. ${ }^{251}$ Apesar do termo nos orientar para uma objetivação, o esquematismo metodológico passa ao largo da experiência entendida por Heidegger. Gadamer admite, em Verdade e Método, que há mesmo uma insuficiência de pensamento no que diz respeito a uma teoria que direcione a experiência para fora da objetivação do método científico. $\mathrm{O}$ autor conta que o próprio Husserl, que se voltou para uma genealogia da experiência, tem dificuldade de se mover em direção a sua essência uma vez que faz da percepção, concebida como externa e relacionada à corporalidade, o critério último de toda a experiência. $^{252} \mathrm{Um}$ segundo ponto que gostaríamos de mencionar, é que a experiência aqui pensada também não diz respeito ao entendimento de Hegel quando, no décimo quarto parágrafo da Fenomenologia do Espírito - texto inicialmente nomedo "Ciência da experiência da consciência" -, se refere ao movimento dialético que a consciência exerce sobre si mesma, i. e., o lugar em que

${ }^{251}$ Cf. HEIDEGGER, "O tempo da imagem do mundo", in:

${ }^{252}$ Cf. GADAMER, Verdade e Método I, p.454-455. , Caminhos de Floresta, p.103. 
o objeto da consciência é a própria consciência, designando, com isso, a subjetividade do sujeito que imprime sobre a consciência o desdobramento não só sobre o seu saber, mas também sobre o seu próprio objeto. ${ }^{253}$ Muito menos, nos apoiamos em uma vivência como aquela suscitada por Dilthey, cujos estados internos, sobre os quais temos consciência, não podem ser apreendidos senão por nexos mediados pelo mundo. ${ }^{254}$ Não. Não nos atemos a isso. De que forma, então, pensamos a experiência?

Ortega y Gasset nos oferece, no texto "Ensayo sobre lo que le pasó a Aristóteles con los princípios", uma preciosa orientação para o histórico dessa palavra que, em nosso entendimento, serve de pista para aquilo que Heidegger pretende nos mostrar. Segundo ele, experiência - empeiría - é uma palavra que, tanto no grego como no latim - experientia -, tem como raiz o per, que significa atravessar. Nas línguas germânicas a raiz é fahr, como em Er-fah-rung. Segundo o autor, essa raiz pertence a um campo semântico muito interessante e deve ser explorada. Para isso, devemos nos voltar para a palavra em seu sentido primevo, pois, ainda que a língua insista em nos dizer o sentido corrente - encoberto por generalizações que petrificam a palavra -, às vezes, seus sentidos originários emergem e a raiz das quais as palavras são formadas revivem com toda a força e energia. Devemos, portanto, nos direcionar em sentido contrário àquilo que possui um caráter de funcionalidade e praticidade, para, de fato, nos aproximarmos do vazio - lugar onde habita o sentido das coisas -, e, com isso, nos aproximarmos das palavras não naquilo que elas representam, mas de modo a torná-las próprias com aquilo que $e^{255}$ É nesse sentido que per é entendido originariamente pelo filósofo espanhol como "viajar, caminhar ao redor do mundo quando não havia estradas, quando toda a viagem era mais ou menos desconhecida e perigosa" 256 - lembremos do vocábulo Gefahr que também tem a mesma raiz e significa perigo, risco, uma situação de ameaça, como alguém que viaja por terras desconhecidas sem orientação, sem um método ou guia. Em alemão fahren significa andar, viajar; land fahren, andar por terras. Ao fahren acrescentamos sempre a ideia de movimento. Ortega y Gasset nos ensina que a experiência é algo que se funda efetivamente a

\footnotetext{
${ }^{253}$ Cf. HEIDEGGER, "O conceito de experiência em Hegel”, in: Caminhos de Floresta, p.209-216.

${ }^{254}$ Cf. BAMBACH, Heidegger, Dilthey and the Crisis of Historicism, p.153.

${ }^{255}$ Cf. HEIDEGGER, Língua de Tradição e Lingua Técnica, p.7ss.

256 ORTEGA Y GASSET, Obras Completas; Tomo VIII, p. 176. Tradução nossa.
} 
partir de um andar, de um atravessar por terras desconhecidas ou inabituais. Segundo ele, essa compreensão proporciona uma aproximação muito mais concreta e viva da palavra experiência do que qualquer definição epistemológica. Entendemos, portanto, que a experiência em sua essencialidade deve ser de tal ordem que nos mova, nos faça andar, e andar por terras desconhecidas e perigosas! Assim, sem essa abertura, sem essa disponibilidade de lançar-se ao desconhecido, sem essa liberdade de entrega não se faz a experiência, ficamos na mera superficialidade de uma vivência. Mas, seria a experiência algo que nós mesmos promovemos? Estaria essa experiência essencial ancorada em nosso querer? Não cremos. A julgar pela descrição que Heidegger nos oferece, em "A essencia da linguagem", conferência realizada em 1958, é a experiência que chega até nós, somos afetados por ela. Leiamos com atenção o que ele diz:

Fazer uma experiência com algo, seja com uma coisa, com um ser humano, com um deus, significa que esse algo nos atropela, vem ao nosso encontro, chega até nós, nos avassala e transforma. "Fazer" não diz aqui de maneira alguma que nós mesmos produzimos e operacionalizamos a experiência. Fazer tem aqui o sentido de atravessar, sofrer, receber o que nos vem ao encontro, harmonizando-nos e sintonizando-nos com ele. ${ }^{257}$

Através dessas palavras, vemos que uma vez alcançados pela experiência não há controle, é a própria experiência que nos conduz e governa. Sobre ela a vontade do homem nada diz. Impõe-se, dessa forma, uma relação, cujo atravessamento o coloca em sintonia com algo novo. Tal experiência ressoa profundamente nas palavras de Octavio Paz, que nos brinda com uma belíssima passagem sobre a experiência essencial, por ele chamada de "outra margem", como sendo um acontecimento priomordial para o homem. Ele diz:

a experiência da "outra margem" implica uma mudança de natureza: é um morrer e um nascer. Mas a "outra margem" está em nós mesmos. Sem nos mover, quietos, somos arrastados, impulsionados por um grande vento que nos explusa para fora de nós. Ele nos joga para fora e, ao mesmo tempo, nos empurra para dentro de nós. [...] O homem é desarraigado como uma árvore e arremessado para lá, para a outra margem, ao encontro de si. E aqui se apresenta outra característica extraordinária: a vontade intervem pouco [...]. Se foi escolhido pelo grande vento, é inútil que o homem tente resistir. ${ }^{258}$

Trata-se, como vemos, de uma experiência de morte e rensacimento, de uma "mudança de natureza", de uma total ressignificação da vida. Assim como

${ }^{257}$ HEIDEGGER, "A essência da linguagem", in:

${ }^{258}$ PAZ, O Arco e a Lira, p.129. , A Caminho da Linguagem, p.121. 
Heidegger, o poeta mexicano nos fala do atravessamento do outro que se encontrava velado, da outra margem que também é ele próprio. Paz expressa a imobilidade, a quietude da incapacidade de controle e utiliza a metáfora do vento para revelar o arrebatamento do trespassamento - da transcendência - que é também imanência, na medida em que ao mesmo tempo que "joga para fora, [...] empurra para dentro". Trata-se, como o poeta diz mais à frente, do sopro de um grande vento que rompe com toda a cadeia de causas e efeitos e lança o homem "rumo ao vazio ou pleno do ser." ${ }^{259}$ Entendemos que a experiência narrada por Paz abarca o homem em sua totalidade e diz respeito ao espaço de abertura ao próprio ser. Mas de que forma essa experiência essencial se desdobra na relação com o nada?

$\mathrm{Na}$ problematização do nada, Heidegger vislumbra uma clareza que o impele à questão do ser do ente. A resposta buscada pela tradição para a expressão ex nihilo nihil fit que diz: nada surge do nada, apresenta diferentes possibilidades de interpretação e o nada assume historicamente, por assim dizer, a característica de negação do ente verdadeiro. Todavia, sabemos que, para o filósofo, “o nada não permanece o indeterminado oposto do ente, mas se desvela como pertencente ao ser do ente" ${ }^{260}$, ou seja, há uma pertença entre o ser do ente e o nada que só se desvela nessa experiência.

É, pois, fundamental que se reflita sobre o nada. Devemos direcionar nosso olhar com calma em direção ao nada e vislumbrar suas inúmeras possibilidades de sentido, ao invés de, na pressa da superficialidade, o determinarmos como insubstancial e nadificador. É somente com uma abertura de espírito que poderemos experimentar a amplitude daquilo que assegura e propicia a possibilidade do ente ser. Sem o nada que nos remete à angústia fundamental permaceríamos na privação do ser. Somente aquele que entende o chamado do ser pode experimentar tudo aquilo que o ente é em sua plenitude e verdade. Mas, ainda cabe a questão: o que seria a essência dessa experiência? Hermógenes Harada, no texto "Da Experiência", nos fala que a experiência só é experiência na medida em que acolhemos em nossa existência o vigor de ser. ${ }^{261} \mathrm{O}$ vigor de ser seria, então, a essência da experiência? O que é o vigor de ser? O que subjaz por trás disso? Segundo o autor, não chegamos

\footnotetext{
259 PAZ, O Arco e a Lira, p. 131.

${ }^{260}$ HEIDEGGER, “Que é Metafísica?", in: __ Os Pensadores, p.61.

${ }^{261}$ Cf. HARADA, "Da Experiência", in: Coisas, velhas e novas, p.45.
} 
à compreensão do que seja a essência da experiência ou do vigor de ser assim tão facilmente, pois na nossa relação com a realidade da coisa só encontramos a objetivação da coisa. O próprio questionar: o que é isto?, por si, revela uma especificidade do tipo de pensamento que interdita qualquer possibilidade de experiência. A pergunta pela essência da experiência, na medida em que é colocada a posteriori, é tardia, pois o ato de perguntar sobrevém à experiência em si. Todavia, a própria pergunta, ainda que nos coloque apenas parcialmente na resposta, já é em si mesma uma pergunta essencial, e é somente através de perguntas essencias, que podemos chegar à essência do experimentar. Não só o ato de perguntar é posterior, mas o próprio pensar, dizer, conceber palavras, são todos atos do intelecto, e, nas terras estranhas e perigosas da experiência, tais faculdades não fazem morada. Como já dissemos, na experiência do nada há apenas o silêncio, a suspensão de tudo. Suspensos no vazio pleno dessa experiência somos conduzidos ao mais absoluto silenciar, à radical expressão do nada; somos levados à compreensão de que na senda do não-saber reside algo anterior a todas as nossas determinações, seja da ordem do querer, do fazer, do saber, enfim, de tudo aquilo que nos coloca em imediata objetivação com tudo o é. Aí, existe algo que se subtrai para aquém ou além dos entes da existência, algo que ressoa no silêncio, uma ausência que, no entanto, também é presença. Nos referimos aqui a um campo de presença constituído de uma ausência. Falamos da essência da experiência. Esse lugar que sendo é acontecimento, chegada, reunião, automanifestação, o brilho luminoso do que se assenta diante de nós a partir de uma ausência. É, portanto, no silêncio que a claridade da ressonância se faz, que o silenciar da existência se manifesta, e é na escuta obediente que habita o vigor de ser. O escutar, que nada tem a ver com sonoridade e tonalidade, é, pois, constitutivo da própria abertura primordial para o poder-ser mais próprio do Dasein, é o estar aberto ao chamado do ser. Segundo Heidegger, é o pensamento fundamental e originário aquele único capaz de ecoar a voz silenciosa do ser e fazer germinar em palavras a linguagem no homem. Ao longo da história sempre existiu esse tipo de pensamento que pensa a verdade do ser, pois de que modo encontraria o homem rastros para encontrá-lo? É através de lentos sinais que o pensamento essencial busca naquilo que não pode ser calculado algo que não pode ser antecedido pelo pensamento, mas que deseja fazer caminho na história do homem: o ser da verdade. 
Como vimos, Heidegger utiliza o termo in-sistência para caracterizar esta permanência mesma do pensamento essencial na disposição para o encontro. Um pensamento atento à voz do ser, que busca na palavra o destino para que a verdade do ser se torne linguagem. Todavia, como acabamos de ver, para que isso aconteça, é necessário o calar, é necessário o silenciar, é necessária a escuta. O silêncio e a escuta são, pois, condições fundamentais para o brotar da palavra, e é em meio à radicalidade do abismo do nada - que faz brotar o espanto incapaz de pronunciar a palavra -, quando nos confrontamos com a total impossibilidade de ser-no-mundo, com a suspensão de todos os nossos referenciais, perdidos de nós mesmos na estranheza da angústia, que o mundo surge, irrompe e emerge em todo o seu esplendor e beleza. Aí, o destino do homem chegou à sua plenitude. É na radicalidade dessa experiência que existimos. É na radicalidade dessa experiência que ouvimos o silêncio eloquente das coisas. É na ressonância do silêncio que somos linguagem. Somente quando a palavra calada irrompe seu silêncio no mundo e na história da humanidade é que a verdade do ser chega ao seu destino. A linguagem é, pois, única senda para o resplandecer do ser no mundo, daí o pensamento essencial proteger e cuidar da palavra em sua origem. Heidegger nos diz que o nomear do poeta também trilha o mesmo caminho que o pensar. Todavia, a palavra do poeta vela o sagrado e a do pensador, o ser. Com isso, o filósofo infere que o poetar tem sua origem no pensamento originário sem ser um pensamento para si mesmo, já que seus destinos são distintos. Todavia, ambos os dizeres se põem genuinamente de modo inaugural. É somente no poetar e no filosofar que nos encontramos circunscritos à singularidade da palavra, pois aqui o que vemos é a transposição do ser do poeta ou do filósofo para o horizonte de uma verdade. O poeta e o filósofo são, por fim, aqueles capazes de ouvirem o silêncio do mundo e verterem em palavras o testemunho da experiência desse encontro, pontes que buscam levar as margens do extraordinário ao ordinário.

O atravessamento dessas margens é narrado por Octavio Paz como a própria força do momento de criação poética, lugar em que "liberdade e fatalidade se encontram no homem." 262 Entendemos que a liberdade e a fatalidade, aqui mencionadas, dizem respeito ao próprio poetar - à possibilidade de envio que se abre a partir de uma experiência essencial permeada de silêncio e morte, condição

262 PAZ, O Arco e a Lira, p. 129. 
necessária para que a poesia possa ser. Voltemo-nos ao lugar do poético e ouçamos a voz de Pessoa ao reconhecer-se como passagem para o outro, para a poesia. Em 1932, ele diz:

Não meu, não meu é quanto escrevo,

A quem o devo?

De quem sou o arauto nado?

Porque, enganado,

Julguei ser meu o que era meu?

Que outro mo deu?

Mas, seja como for, se a sorte

For eu ser morte

De uma outra vida que em mim vive,

$\mathrm{Eu}$, o que estive

Em ilusão toda esta vida

Aparecida,

Sou grato. $[\ldots]^{263}$

Ou, quando proclama, na parte XI, de "Os passos da cruz":

Não sou eu quem descrevo. Eu sou a tela

E oculta mão colora alguém em mim.

Pus a alma no nexo de perdê-la

E o meu princípio floresceu em Fim. ${ }^{264}$

O poeta tem uma compreensão clara de sua própria morte para que algo floresça. Ele entende notadamente a poesia como a graça de destinar quando diz "se a sorte for eu ser morte de uma outra vida que vive em mim [...] sou grato". Pessoa sabese passagem para o poético, fala-nos de ser a tela para uma mão oculta criar, do fazer-se nada para, a partir dessa experiência, algo outro, original, emergir, do poder perder-se para encontrar-se, enfim, fala-nos da própria experiência de uma abertura para a alteridade, seja ela a obra, o heterônimo ou o outro de si mesmo - o próprio ser.

Ainda que a justificativa estética futurista, trazida pela abolição do eu na poesia, nos fale de um lugar tão visitado pelos poetas modernos, e mesmo sabendo que, em contraposição, os eus pessoanos são bem demarcados - apesar de sabê-los totalmente distintos de um eu cartesiano, no sentido de uma fundação epistemológica, na medida em que essa demarcação se funda tão somente como eixo estrutural da obra pessoana, a qual " [...] permite ao eu lírico uma abordagem

${ }^{263}$ PESSOA, Obra Poética, p.164.

${ }^{264}$ Ibidem, p. 127. 
do real sempre de modo indireto, despersonalizado"265 -, isto não invalida o que vemos com clareza: a experiência do nada pessoano como aquilo que alavancou a existência de uma pluralidade, ou melhor, a experiência poética do nada como abertura para o próprio poetar, a qual, no caso de Pessoa, se intensifica na agudeza de não ser ninguém para ser muitos, na compreensão de que para criar-se seria necessário primeiro destruir-se ${ }^{266}$, ou mesmo, do fazer-se "nada para poder ser tudo e todos" 267 - o lugar em que se instaura a linguagem e a poesia, o lugar em que a poesia, em seu frescor de nomeação, é a relação com a própria palavra, em que a palavra vem a ser exemplarmente palavra.

Em total sintonia com o escritor moderno, os heterônimos pessoanos nascem simultaneamente com seus textos. Não há, pois, aquele alguém que precede o texto, mas apenas o momento em que a escrita se dá, o acontecimento que se abre no aqui e agora da criação poética. Ao menos é assim que Pessoa, no fim de sua vida, - ele falece em 30 de novembro de 1935, aos 47 anos de idade -, nos dá a saber na famosa carta a Adolfo Casais Monteiro, datada de 13 de janeiro do mesmo ano. Façamos notar que esta é uma visão trazida por Pessoa no ano de sua morte, portanto, o poeta já teria olhos críticos para ver a heteronímia de fora do seu processo criativo. ${ }^{268}$ Ouçamos um trecho da famosa carta:

[...] acerquei-me de uma cómoda alta, e, tomando um papel, comecei a escrever, de pé, como escrevo sempre que posso. E escrevi trinta e tantos poemas a fio, numa espécie de êxtase cuja natureza não conseguirei definir. Foi o dia triunfal da minha vida, e nunca poderei ter outro assim. Abri com o título O Guardador de Rebanhos. E o que se seguiu foi o aparecimento de alguém em mim, a quem dei desde logo o nome de Alberto Caeiro. Desculpe-me o absurdo da frase: aparecera em mim o meu mestre. Foi essa a sensação imediata que tive. E tanto assim que, escritos que foram esses trinta e tantos poemas, imediatamente peguei noutro papel e escrevi, a fio, também, os seis poemas que constituem a Chuva Obliqua, de Fernando Pessoa. [...] Aparecido Alberto Caeiro, tratei logo de lhes descobrir [...] uns discípulos. Arranquei do seu falso paganismo o Ricardo Reis latente, descobri-lhe o nome e ajustei-o a si mesmo, porque nessa altura já o via. E, de repente, e em derivação oposta à de Ricardo Reis, surgiu-me impetuosamente um novo indivíduo. Num jacto, e à máquina de escrever, sem interrupção nem emenda, surgiu a Ode Triunfal de Álvaro de Campos - a Ode com esse nome e o homem com o nome que tem. Criei, então, uma coterie inexistente. [...] Graduei as influências, conheci as amizades, ouvi, dentro de mim, as discussões e as divergências de critérios, e em

\footnotetext{
${ }^{265}$ FERNANDES, "Tradição, Modernidade e Modernismo na Lírica Portuguesa", in: Leituras da Modernidade, p.121.

266 Segundo Robert Bréchon, essa compreensão está presente em Pessoa desde os 17 anos, quando o poeta escreve as primeiras notas ao Livro do Desassossego. (Cf. BRÉCHON, Estranho Estrangeiro: Uma biografia de Fernando Pessoa, p.78.)

${ }^{267}$ ZENITH, "Introdução", in: PESSOA, O Livro do Desassossego, p.14.

${ }^{268}$ Cf. OSAKABE, Fernando Pessoa: Resposta à Decadência, p.108.
} 
tudo isto me parece que fui eu, criador de tudo, o menos que ali houve. Parece que tudo se passou independentemente de mim. E parece que assim ainda se passa. ${ }^{269}$

Trata-se de uma narrativa na qual o ato criativo acontece antes de seus autores, e não o contrário! É a poesia de Pessoa anterior ao surgimento de Caeiro, Campos e Reis"270, diz Lourenço. Isto significa que os poemas "surgem" e é a partir deles que os outros pessoanos adquirem vida própria, são dotados de personalidade, biografias (e até mapa astral!). É de se fazer notar que Pessoa ortônimo também se inclui nesse longo processo de descrição da gênese dos heterônimos. Ele também nasce nesse mesmo movimento de outrar-se. Por outras palavras: primeiro os poemas, depois os autores. São os poemas que dão vida aos outros de Pessoa, são os poemas o lugar e a hora da heteronímia, ou seja, a existência do outramento só faz sentido no simultâneo desdobrar da totalidade do corpo poético. A heteronímia pessoana pode, pois, ser entendida como essa constelação de eus que não é nenhum e, ao mesmo tempo, é todos. Trata-se de uma conjunção poética que está “ sempre numa relação que implica movimento, transformação, dinamismo vital, um mundo em movimento que sai de si e fica em si ao mesmo tempo." ${ }^{271}$ Esta é a genialidade da heteronímia que, em última instância, só acontece porque Pessoa deixou-se ser tomado pelo outro, por aquilo que o ultrapassa e transcende - e deixou-se ser esse outro, essa diferença - e, com isso, ser poesia.

Mesmo que toda a questão heteronímica esteja embasada por questões de ordem literária, psicológica ou mesmo sociológica ${ }^{272}$, é o próprio Pessoa que diz ser movido por inquietações filosóficas, e "é essa identidade que melhor justifica seu processo criador e o universo de sua criação." ${ }^{273}$ Logo, o outrar-se pessoano nos importa na medida em que o escopo de nosso trabalho se volta para o próprio ato da criação poética e de sua experiência - falamos do caminho da poesia e da linguagem poética como uma forma de acesso àquilo que Heidegger entendeu com linguagem originária. Ainda que Caeiro, Campos e Reis "existam” autonomamente, e mesmo, em menor presença, Guedes, Barão de Teive e Soares, há apenas um poeta - há apenas o ser-poeta Pessoa - em sua inimaginável e inextinguível

\footnotetext{
269 PESSOA, Obras em Prosa, p.96.

${ }^{270}$ LOURENÇO, Pessoa Revisitado, p.40. Itálicos do autor.

271 OSAKABE, Fernando Pessoa: Entre Almas e Estrelas, p. 37.

${ }^{272}$ Sabemos, com Eduardo Lourenço, que essas três perspectivas são representadas respectivamente pelas exegeses de João Gaspar Simões, Jacinto do Prado Coelho e Mário Sacramento. (Cf. LOURENÇO, Pessoa Revisitado, p.31.)

${ }^{273}$ OSAKABE, op. cit., p.27.
} 
capacidade de por-se em obra, ser ele mesmo poemas que geram e dão vida a tantos outros. Não seria exatamente isso o que quer dizer Octávio Paz quando afirma que a linguagem do poema está no poeta e somente nele se revela? ${ }^{274}$

Cabe aqui ainda uma reflexão. O que seria esse outro pelo qual o poeta se deixa tomar? Não se trata de pensarmos esse outro como um eu heteronímico, ainda que Pessoa assim nos faça entender. Isto que o ultrapassa e transcende não é um heterônimo, mas, a própria alteridade que, sim, é diferença. No outramento nos referimos a um outro, que, apesar de diferente, não é oposto. Nos referimos aqui à dobra entre ser e ente, a qual nos fala de um caráter eventual da presença que jamais deixa-se comprovar. Algo que, de imediato, nos fala de uma interdição, de um impedimento. Entretanto, mesmo cientes dessa dificuldade, busquemos, através do pensar de Heidegger, alguma compreensão para a questão. Dissemos que não há uma oposição no outramento, mas uma alteridade que é transcendência e deve ser entendida como diferença enquanto tal. Não podemos, portanto, falar de uma uniformidade, devemos nos ater a uma unidade que se estabelece a partir de uma comum-pertença ou àquilo que mutuamente se pertence no interior do mesmo. ${ }^{275}$ Mas, o que é essa pertença? Não falávamos de uma diferença? De um outramento? Como podemos falar em mesmidade? Como entender que nessa alteridade e transcendência há uma pertença? Sigamos o pensar do filósofo alemão.

$\mathrm{Na}$ conferência "O princípio da identidade", pronunciada por ocasião do quingentésimo jubileu da Universidade de Freiburg, em 27 de junho de 1957, o pensador nos fala que essa pertença significa uma relação com o próprio ser, significa estar inserido no ser. Isto quer dizer que na medida em que o homem é um ser que pensa, encontra-se aberto para o ser, i. e., está em uma permanente relação de correspondência com ele. Segundo o pensador, essa relação de correspondência não é uma limitação para o homem, mas, ao contrário, é a expressão máxima da plenitude. É como um voltar para casa, na medida em que esta é uma relação primordial. Mas como ser e pensar podem estar numa relação de pertença ao mesmo? Heidegger entende que é justamente na diferença que ser e pensar se copertencem. Ainda que sejam distintos, ambos seriam característicos de uma unidade original. Notemos que o mesmo não quer dizer igual. Não há, como

${ }^{274}$ Cf. PAZ, O Arco e a Lira, p.60-61.

${ }^{275}$ Cf. HEIDEGGER, "Identidade e Diferença", in: Os Pensadores, p. 177. 
afirmamos mais acima, uma uniformidade. Há, precisamente nessa diferença, uma relação de pertença mútua entre os dois termos evidenciada pelo mesmo. Isto significa que ser e pensar estão abrigados em uma pertença recíproca. Pensada em termos de uma mútua pertença, a relação entre ser e pensar aconteceria justamente na sua diferença e o mesmo seria o elo capaz de, mesmo na diferença, manter ambos em relação de copertencimento. ${ }^{276}$ Este comum-pertencer acentua que, além de estarem imbricados num recíproco pertencer, através desta reciprocidade, ser e pensar fazem parte de uma mesma unidade, de uma mesma da identidade, do mesmo. Não devemos, contudo, entender essa identidade como a tradição metafísica entendeu: um princípio que afirma que todo o ente pertence a uma unidade consigo mesmo, o qual pressupõe a identidade como um traço do ser e este como um fundamento do ente. Não. Para Heidegger, pensar o ser a partir da identidade significa um salto no abismo, que distancia o ser como fundamento do ente, para o comum-pertencer entre homem e ser; uma comum-unidade que se forma a partir da dobra entre ser e ente, que, como veremos no próximo capítulo, se relaciona com a essência da linguagem. Há, portanto, para o pensador alemão, uma relação de pertença ou copertencimento entre ser e pensar. Esta ideia é reforçada pela sentença encontrada na carta Sobre o Humanismo, escrita de 1947, que diz: "[...] o pensamento é o pensamento do ser." 277 Há aqui um duplo sentido neste possessivo: tanto significa que o pensamento deve ser compreendido como pertencendo ao ser, lugar de onde encontra a sua origem, quanto como para o qual se encaminha a sua escuta e apelo. É, pois, a escuta que nos orienta para o ser. Todavia, para que a escuta se dê é preciso que o homem esteja aberto, ou melhor, para que o ser se presentifique é preciso que o homem escute o seu chamado. A relação entre ser e pensar será aprofundada mais à frente, quando entrarmos na questão da corporeidade. Por ora, nos interessa entender o que é ser tomado pelo outro, por aquilo que nos ultrapassa e transcende - e deixar-se ser esse outro, essa diferença - e, com isso, ser linguagem, ser poesia.

Retomemos o passo de modo a tornar a questão mais palatável. O poeta é, pois, aquele que se deixa atravessar por essa alteridade exatamente porque é escuta, abertura e entrega ao apelo do ser. Esta relação de pertença ou copertencimento,

${ }^{276}$ Cf. HEIDEGGER, O Princípio do Fundamento, p.152-153.

${ }^{277}$ HEIDEGGER, Sobre o Humanismo, p.28. 
que deve sempre ser pensada a partir da noção de salto, é nomeada por Fogel, em Homem, Realidade, Interpretação, como arcaico-original, e é anterior aos termos da própria relação. Não se trata, pois, da relação de um termo com outro ou de um polo com outro, quando eu estou aqui e a coisa lá. Tudo isso é posterior. É porque a relação já se deu que os termos ou polos podem aparecer como termos ou polos. Segundo o autor, a relação é o próprio lugar onde se instaura uma abertura prévia que permite ou possibilita que um seja para o outro e o outro para um, colocandoos em tensão de mútuo pertencimento - o pertencer mútuo de um para o outro e do outro para um, de tal modo, que

ambos são na co-pertinência, na encruzilhada, na conjunção, que sempre já aconteceu ou se deu. Este já é a fala do insondável, do inapropriável, do irrepresentável, quer dizer, daquilo para o qual a representação e a apreensão sempre chegam atrasadas, tarde demais, por isso já se deu - cedo demais! Isto define a circunscrição absoluta, ou seja, o âmbito fora do qual, antes ou depois, aquém ou além, nada há, nada é. ${ }^{278}$

Tudo isto que já se deu e fora do qual nada há é arché, é origem, é irrupção - o raio inaugural do nosso destino, do ser si mesmo, si próprio. Referimo-nos aqui à experiência autêntica de ser tocado, atravessado, perpassado por um tal modo de ser que determina tudo o que é e há. Falamos de phátos - de ser tocado e tomado por uma tal possibilidade -, das noções de experiência e afeto. Normalmente, se traduz páthos por paixão, mas, etimologicamente, a palavra reporta a páskhein, que significa sofrer, aguentar, deixar-se convocar por. ${ }^{279}$ Heidegger traduz páthos por dis-posição, no sentido de exprimir uma tal tonalidade afetiva que nos chama ao apelo e nos harmoniza. Com isto, Heidegger se afasta da compreensão carregada do sentimentalismo exacerbado, trazida pela psicologia moderna. Na realidade, isto que nos convoca e harmoniza fala de um mesmo fenômeno: de uma experiência essencial, primordial e constitutiva do homem. Como vimos, não se trata de faculdades ou propriedades que estão instauradas na consciência ou no arbítrio humanos, assim como pensou Descartes. Não nos referimos a uma autonomia da subjetividade, mas, falamos, sim, de abertura, horizonte, lógos, mundo, os quais sobrevêm ao homem - por isso, são da ordem da transcendência - e são determinantes para os modos possíveis de vida ou existência, pois, isto que advém sobre o homem o atravessa, dele se apropria, o transforma e o singulariza como um

\footnotetext{
${ }^{278}$ FOGEL, Homem, Realidade, Interpretação, p.71.

${ }^{279}$ HEIDEGGER, “Qu'est-ce que la philosophie?", in: , Os Pensadores, p.38.
} 
determinado homem. É somente a partir daí que o "eu" aparece, surge. Por outras palavras: na medida em que o homem é abertura para a realidade da liberdade como possibilidade para possibilidade, para o poder ser si próprio, ele pode ser tocado, afetado, atravessado por uma experiência, um acontecimento - que é transcendência na medida em que originariamente se dá independentemente da sua vontade ou querer - o qual, em se realizando, instaura um tal modo de ser que o distingue e singulariza como um homem, como um "eu”, um "eu”que vê.

Trazendo toda essa questão para o nosso poeta, será somente a partir desse afeto, da experiência dessa alteridade que o heterônimo será formado, constituído e cunhado, e é somente porque há uma entrega e abandono a essa alteridade que surge uma identidade, um "eu" que se faz no fazer-se da linguagem. Isto significa dizer que é no fazer da poesia que surge o poeta. Um “eu” que só se constitui pelo acontecimento que irrompe, na medida em que Pessoa é abertura, é pura possibilidade de ser tomado, tocado, atravessado por uma tal possibilidade para possibilidade. Trata-se, em suma, de uma identidade que é constituída pelo fazer que Pessoa faz, ou melhor, que ele deixa-se-fazer nele. Cada outro pessoano traz em si um outro horizonte, um outro mundo, um outro lógos, uma outra linguagem, uma outra poética, um outro modo possível de ser-aparecer, de ser-realidade. Cada heterônimo é, de fato, a possibilidade de um mundo que ultrapassa Pessoa, o transcende. Isso irrompe, acontece, o atravessa, de tal forma, que não está em seu poder decidir sobre essa realidade. Dá-se. Por isso não há “eu”, não há sujeito, nem consciência. Há somente a experiência, o afeto, o phátos, que, segundo Fogel, “encerra uma noção que é constitutiva ou essencial dessa estrutura-instante, que é o lastro ou o fundo ontológico da vida." ${ }^{280}$ Trata-se de uma experiência determinante para um tal modo de ser que é puro fluxo e expressão de vida!

Com isso, não desejamos, de modo algum, minimizar a heteronímia, ao contrário, ela é, sem dúvida, a exacerbação do ato criativo. É exatamente porque a enxergamos com lentes de aumento que cremos que Pessoa viveu a angústia, a experiência da nadificação em sua maior radicalidade, sendo esta experiência, nas palavras de Kierkegaard, "a realidade da liberdade enquanto possibilidade para a possibilidade"281; e, nas de Heidegger, "a possibilidade de ser livre para o poder-

${ }^{280}$ FOGEL, Homem, Realidade, Interpretação, p.23.

${ }^{281}$ KIERKEGAARD, O Conceito de Angústia, p.45. 
ser mais próprio". ${ }^{282}$ Neste ser mais próprio dá-se o envio do ser, a possibilidade autêntica de ser si mesmo. Ainda que no ser mais próprio pessoano exista o múltiplo, ele é, antes de tudo, um só. Ainda que em nosso texto tenhamos dado vida a cada outro pessoano, só há um ser-poeta. Eduardo Lourenço, referindose aos equívocos das exegeses pessoanas, diz: "Há um só poeta, autor de poemas de aparência diversa que como tais devem ser tomados e compreendidos, e acabouse.”283 Não há, pois, como separar a poesia do jogo criado por Pessoa, "a compreensão da poesia do autor de $A$ Tabacaria e a do jogo heteronímico vão de par"284, diz o autor. Trata-se do abismo do outramento poético que, no caso de Pessoa, se potencializa na direção de uma saga heteronímica que hoje compõe um quadro de 136 outros.

A exacerbação dessa pluralidade vai de encontro à demanda do contínuo desenrolar do próprio gesto poético - do silêncio e da escuta. Há aqui algo que se faz desde um imperativo vital: aqui o homem desaparece, há apenas a entrega, o abandono à dimensão da transcendência e ultrapassamento da subjetividade, há apenas a espera e a escuta a desdobrar-se em abertura. Como se o poeta se ausentasse de si mesmo para dar vazão ao fluxo de outros que o acomete, sendo que esse outramento é também ele mesmo, e esse fluxo, a própria poesia a impor-se sobre o poeta, a convocá-lo à consagração do instante. O que distingue o poetar é exatamente a capacidade de lançar-se no vazio, de ser silêncio e deixar-se atravessar por essa(s) voz(es), e, a partir dessa escuta, ser poemas. O ato de criação é, pois, o lugar e a hora em que poeta e poesia se criam mutuamente. Num constante fazerse. Num contínuo criar-se. Mas, é preciso sair de si, para poder retornar a si. É preciso morrer, para renascer. De Pessoa nascem Caeiro, Campos e Reis, além de toda a sua coterie. Todos eles são Pessoa, aquilo que ele mesmo é. Nele habitam todos eles. Nele habita o mundo. Ouçamos, na voz de Álvaro de Campos, na expressão ampliada do poeta plural, que se divide e se junta, que é um e é todos, que é nada e é tudo. Ouçamos seus versos:

[...] Eu, a ama que empurra os perambulators em todos os jardins públicos, $\mathrm{Eu}$, o polícia que a olha, parado para trás na álea, Eu, a criança no carro, que acena à sua inconsciência lúcida com um colar com guizos,

\footnotetext{
${ }^{282}$ HEIDEGGER, Ser e Tempo, p.204. Itálico do autor.

${ }^{283}$ LOURENÇO, Pessoa Revisitado, p.38.

${ }^{284}$ Ibidem, p.30.
} 
$\mathrm{Eu}$, a paisagem por detrás disto tudo, $[\ldots]$

$\mathrm{Eu}$, o ditado de francês da pequenita que mexe nas ligas,

$\mathrm{Eu}$, os pés que se tocam por baixo do bridge sob o lustre,

Eu, a carta escondida, o calor do lenço, a sacada com a janela entreaberta, [...]

$\mathrm{Eu}$, tudo isto, e além disto o resto do mundo...[...] $]^{285}$

Osakabe, em Fernando Pessoa: Entre Almas e Estrelas, referindo-se aos múltiplos textuais que se opõem e complementam, nos traz a seguinte análise:

Reside aí, nessa complexa e ao mesmo tempo simples manipulação de significantes, o jogo de equiparações e multiplicações de identidades, de forma a confundir criador e criatura, não definíveis como um eu ou como um outro, mas como uma simbiose estranha que estabelecendo o amálgama, montam o uno $\mathrm{e}$ mantém intactos os elementos diferenciadores. ${ }^{286}$

Sobre a compreensão dessa multiplicidade, Pessoa deixa em um manuscrito, provavelmente escrito em 1915, no qual o poeta nos dá a saber algo desta multiplicidade. Ele diz:

Sinto-me múltiplo. Sou como um quarto com inúmeros espelhos fantásticos que torcem para reflexões falsas uma única anterior realidade que não está em nenhuma e está em todas. [...] Eu sinto-me vários seres. Sinto-me viver vidas alheias, em mim, incompletamente de cada [?], por uma suma de não-eus sintetizados num eu postiço. ${ }^{287}$

Trata-se da compreensão de sentir-se múltiplo - uma realidade que está em nenhuma e em todas, ao mesmo tempo. Esta multiplicidade ou "pulverização de eus", como diz José Gil em O Devir-Eu de Fernando Pessoa, nos fala de um planomultidão, de uma superfície de circulação de fluxos de vida e pensamentos, onde, dentro de uma perspectiva deleuziana, “o Eu não é já um sujeito, mas um puro plano em que pode surgir qualquer mundo, qualquer realidade, brotando num fluxo intensivo" 288 . Por outras palavras: o autor reforça a ideia de que não devemos confundir essa "pulverização de eus" como provenientes de uma instância psicológica a qual sintetiza as impressões, afecções e percepções de um sujeito, mas trata-se de um plano de onde brotam todas as impressões e sensações que formam o mundo, um "plano onde tudo pode começar a existir." 289 , na medida em que é um “espaço da coexistência sucessiva (presente, passado, futuro) ou simultânea de tudo o que é." ${ }^{290}$ Este plano-multidão é, nas palavras de Gil, "o lugar de onde sai a

\footnotetext{
${ }^{285}$ PESSOA, Obra Poética, p. 348.

${ }^{286}$ OSAKABE, Fernando Pessoa: Entre Almas e Estrelas, p. 37.

${ }^{287}$ PESSOA, Páginas Íntimas e de Auto-Interpretação, p.93-94.

${ }^{288}$ GIL, O Devir-Eu de Fernando Pessoa, p.23.

${ }^{289}$ Ibidem, loc. cit.

${ }^{290}$ Ibidem, loc. cit.
} 
plenitude da vida." ${ }^{291}$ Alguns anos mais tarde, ao revisitar a heteronímia, no livro Cansaço, Tédio, Desassossego, Gil retoma a questão a partir da despersonalização literária e diz que os "eus" da heteronímia são uma construção fíctícia. O intérprete questiona se haveria um "eu" criador por trás dos outros "eus" e admite a existência de um dispositivo de forças, que tudo cria e orienta, que o faz repensar a própria noção de "eu”. Para ele, o "eu" esvaziado do próprio Pessoa "é resultado de uma técnica precisa de criação de personagens-outros, que é, afinal, a técnica mais rigorosa e rica de se fazer poesia." ${ }^{292}$

O que vem à tona com essa multiplicidade e com a pulverização de eus da heteronímia é exatamente a desintegração do sujeito moderno, do eu cartesiano, do solipsismo existencial. Trata-se de ser nada para poder ser tudo, do vazio pleno de possibilidades para uma alteridade. Vale lembrar que no centro dessa multiplicidade, no cerne do outrar-se, pulsa o nada, a ausência, o silêncio e a escuta do poetar. Tal solo é anterior a qualquer compreensão psicológica, posto que “psicológico" já é uma organização positiva posterior à nadidade constitutiva do ser si-próprio. Isto significa que o "eu” é uma forma posterior transpassada por uma historicidade e se dá sempre de forma relacional com o mundo. Tentemos por outras palavras: é na medida em que entendemos o ser si-próprio como existencialmente anterior aos conceitos de eu ou ego oferecidos pela tradição, que pensamos ser possível afirmar que a "morte" do próprio Pessoa em favor do próprio poetar, assim como da multiplicidade de todos os outros, se sustenta na compreensão de um desdobrar-se autêntico - o próprio desdobrar-se de si mesmo em obra, um desdobrar-se que ao mesmo tempo que constiui o ser si-próprio, o ser si-mesmo, constitui a obra. Esta é a genialidade de Pessoa: o poeta se desfaz em muitos, mas é um só. Há uma unidade nesta pluralidade. Mas, antes de tudo, Pessoa é nada para poder ser todos. A poesia pessoana, nos diz Lourenço, "situa-se imediatamente no nível do "ontológico" (é ontologia em acto), sendo como é, pura e interminável interrogação sobre o ser múltiplo das 'verdades' ou das 'vivências' em que o pensar nelas as converte." ${ }^{293}$ Ser ontologia em ato significa que a poética de Pessoa é a mais pura e autêntica expressão das infinitas possibilidades que se abrem a partir da experiência do nada, aqui trazidos pelo pensar de Heidegger. Ricardo Reis nos

\footnotetext{
${ }^{291}$ GIL, O Devir-Eu de Fernando Pessoa, p. 29.

${ }^{292}$ Cf. GIL, Cansaço, Tédio, Desassossego, p.69-82.

${ }^{293}$ LOURENÇO, Pessoa Revisitado, p.28.
} 
brinda com uma linda ode, escrita em 1914. Nela, o poeta nos oferece uma compreensão bastante próxima daquiloque desejamos transmitir. Ouçamos seus versos:

\author{
Não tenhas nada nas mãos \\ Nem uma memória na alma, \\ Que quantos te puserem \\ Nas mãos o óbolo último, \\ Ao abrirem-te as mãos \\ Nada te cairá.[...] \\ Senta-te ao sol. Abdica \\ E sê rei de ti próprio. ${ }^{294}$
}

Mãos vazias, alma livre de qualquer memória, abdicar de si para ser rei de si. Esvaziar-se de si mesmo, para ser mais si mesmo. Trata-se de uma espécie de inserção que se faz e se completa no próprio fazer. Inserido nesta circularidade está o corpo. Voltemos nossa atenção para isto agora.

\title{
3.2. Corporeidade: vida se fazendo vida
}

Falávamos da angústia existencial. Falávamos do perder-se de si mesmo como possibilidade para ser si-próprio. Falávamos do ser tomado e perpassado por uma tal experiência originária capaz de ressignificar o mundo. Falávamos, enfim, de uma tonalidade afetiva que nos coloca na totalidade do ente, a qual inaugura e mantém um modo de ser que é abertura. Cabe-nos agora falar de algo que está intimamente ligado a esta tonalidade afetiva: a questão da corporeidade. Mas logo vem a pergunta: como uma tonalidade afetiva pode ter alguma relação com o corpo? Esta é uma questão que buscaremos iluminar ao longo do texto. Por ora, à guisa de introdução, podemos dizer que aquilo que queremos expressar como corpo não é apenas aquilo temos diante dos olhos, mas é algo que está atrelado, permeado, perpassado por tonalidades afetivas. ${ }^{295}$ Sabemos, entretanto, que a compreensão de corpo está atravessada por um pensar que não vê esta inter-relação e se guia exclusivamente de modo unilateral, a partir de uma exterioridade visível e palpável. Por isso, faz-se necessário, antes de mais nada, entendermos que toda essa questão

\footnotetext{
${ }^{294}$ PESSOA, Obra Poética, p.258-259.
}

${ }^{295}$ Cf. HEIDEGGER, Lógica, p.233. 
tem como pano de fundo a ciência moderna que, através de um método objetivante, determina de modo inconteste como entendemos o corpo.

Como vimos no capítulo anterior, a ciência moderna, baseada no método cartesiano de que só pode ser considerado verdadeiro aquilo que pode ser mensurável, acaba por reduzir a corporeidade do homem à objetividade do conhecimento da física ou da biologia. Por isso, quando pensamos em corpo nos remetemos imediatamente ao corpo humano e nos colocamos como porta-vozes de um saber objetivado. Não. Não devemos nos apressar e pensar o corpo em seu aspecto puramente biológico ou físico. É indispensável que passemos de uma compreensão meramente explicativa, sobre a qual temos em mente uma representação objetivada, para uma compreensão a partir do corpo que nós somos: um entendimento do corpo enquanto corporeidade, abertura. Para que possamos nos aproximar dessa outra visada, que nos remete ao mais originário, devemos desviar o olhar do escopo do positivismo da ciência moderna e nos orientar por uma escuta e uma visão que se põem diante do fenômeno que emerge. Ressaltemos o fato que essa orientação nos é dada por uma escuta e uma visão totalmente outra daquilo que entendemos por esses termos. O escutar e o ver aqui perscrutados nada têm a ver com a sonoridade ou com o resultado de um estímulo luminoso, mas, sim, com uma abertura primordial, um tal modo de ser em que o homem se encontra em total sintonia com o mundo; uma dimensão que, uma vez revelada, diz respeito à existência do homem. Heidegger grifa a palavra com um hífen: ek-sistência - lugar em que o prefixo ek- nos remete a uma abertura. Trata-se, como vimos anteriormente, de uma abertura originária na qual a estrutura da vida humana passa a ser compreendida a partir de um processo em cujo cerne está o ser si-próprio do homem; um tal modo de ser, uma dimensão, um horizonte que se abre e dentro do qual concretiza-se aquilo que o homem é, i.e., nesta abertura irrompe aquilo que o homem é na sua singularidade, na sua concreção, como ação, atividade, autoexposição, corporificação, corpo se fazendo corpo. Ortega y Gasset, em o Homem e os Outros, ao se referir ao fato de que o homem é alguém que, antes de qualquer outra coisa, está num corpo, entende que "esse simples mas irremediável fato vai decidir a estrutura concreta do nosso mundo e, com isso, da nossa vida e destino.” ${ }^{296}$ Portanto, a existência humana fala de uma totalidade que é vida, vida

${ }^{296}$ ORTEGA Y GASSET, O homem e os outros, p.97. 
abundante de sentido, plena de possibilidades, e deve ser entendida dentro de um processo historial, como veremos no próximo capítulo. Como poderíamos, então, nos aproximar da corporeidade através dessa visada?

Como dissemos na introdução, nosso caminho se perfaz pela via da fenomenologia. No que diz respeito à Heidegger, não há por parte do filósofo a intenção de estabelecer novos princípios para uma teoria do conhecimento, assim como Husserl pretendia. A fenomenologia para o pensador alemão não é um método que pressupõe uma técnica, mas, um modo de pensar a vida que envolve especialmente a nossa relação com o mundo à nossa volta. Se tomarmos a etimologia da palavra método, veremos que a própria palavra nos orienta para aquilo que originariamente o grego antigo pensou para esse termo: metá- significa ir além, passagem de um lugar a outro; e -hodós, caminho, via. ${ }^{297} \mathrm{O}$ vocábulo método se circunscreve, portanto, à ideia de seguirmos um caminho que nos leva além e não a uma técnica de pesquisa. $\mathrm{O}$ método é o caminho que conduz a um assunto, é a maneira de buscar algo. O que vai determinar o caminho é o próprio modo de ser do ente a ser estudado e não algo previamente estabelecido, traçado. Portanto, pensar o corpo enquanto fenômeno deve nos encaminhar para uma compreensão que nos distancie de todas as determinações prévias que a ciência moderna nos ofertou ao longo do tempo. Sabemos que, diferentemente de uma metodologia dedutiva, do passo-a-passo, a fenomenologia se atém a uma investigação filosófica que busca um retorno às coisas mesmas, ao mesmo tempo que leva em consideração uma compreensão interpretativa. Lembremos somente que, quando nos atemos à palavra compreensão, não nos referimos a um mero discernimento esclarecedor. A compreensão à qual nos reportamos é um modo primordial de ser do Dasein e já está atravessada por uma abertura prévia que funda uma significância existencial, na qual este encontra-se inserido e, a partir da qual, o corpo biológico é interpretado como tardio. Assim, pensar o corpo deve nos encaminhar ao sentido formal de deixar ver o aparecer daquilo que se mostra a partir de si mesmo. ${ }^{298}$ Mas o que significa deixar ver por si mesmo aquilo que se mostra a partir de si mesmo?

Caeiro, em sua simplicidade, esboça uma resposta. O poeta nos fala que é

${ }^{297}$ BÖLTING, Dicionário Grego-Português, p. 378 e 415, respectivamente.

${ }^{298}$ Cf. HEIDEGGER, Ser e Tempo, p.74. 
justamente aquilo que não se mostra e, na maioria das vezes, se mantém velado que toma lugar privilegiado neste modo de se acercar das coisas. Ouçamos seu canto, em um de seus "Poemas Inconjuntos", escrito em 1919:

Gozo os campos sem reparar para eles.

Perguntas-me porque os gozo.

Porque os gozo, respondo.

Gozar uma flor é estar ao pé dela inconscientemente

E ter uma noção do seu perfume nas nossas ideias mais apagadas.

Quando reparo, não gozo: vejo.

Fecho os olhos, e o meu corpo, que está entre a erva,

Pertence inteiramente ao exterior de quem fecha os olhos -

À dureza fresca da terra cheirosa e irregular; $[\ldots]^{299}$

O gozo dos campos e o cheiro da flor só são possíveis porque não se repara neles. Quando se repara, não se goza, apenas se vê com os olhos. É no fechar dos olhos que a visão do ver acontece. É no fechar dos olhos que o corpo comunga com uma pertença, se entrega à terra, ao puro existir, nada além e nada aquém. Aqui, o poeta não se atém a uma descrição minuciosa dos diversos aspectos da natureza sobre o qual se pode obter dados precisos, ao contrário, entrega seu corpo à escuta do mundo e se rende a uma experiência de abertura, congraçamento e gozo. O corpo é, pois, o lugar de encontro com o mundo, é sempre e desde já inserção, relação com o outro e com o todo que o cerca. Vejamos como isso se dá.

Em primeiro lugar, lembremos que não se trata de pensarmos em uma fenomenologia sobre o corpo, mas, a partir do corpo que nós somos. ${ }^{300}$ Heidegger, de forma alguma, pensa em uma mera descrição de algo já constituído ou pensado. O que o filósofo tem em mente parte de uma analítica existencial do Dasein como ser-no-mundo, portanto, a compreensão de corpo também passa por esse existencial; algo que já estava presente em Ser e Tempo e que pergunta por uma constituição fundamental ontológica e não por uma simples descrição dos fenômenos ônticos. Isto não significa que Heidegger negue o caráter ôntico do corpo, afinal, a relação com o outro tem como condição necessária o fisiológico ${ }^{301}$, mas aquilo que aparece onticamente como corpo já surge à luz de uma abertura

\footnotetext{
${ }^{299}$ PESSOA, Obra Poética, p.244; idem, Obra Completa de Alberto Caeiro, p.110.

${ }^{300}$ Para isso, torna-se importante a distinção oferecida pelo próprio filósofo para o uso da palavra corpo: Heidegger usa o vocábulo Leib para o corpo enquanto fenômeno e Körper para o corpo físico, biológico. Para o nosso estudo, esta é uma distinção fundamental, pois é exatamente o corpo enquanto fenômeno que nos interessa. Itálicos nosso.

${ }^{301}$ Cf. HEIDERGGER, Seminários de Zollikon, p.195.
} 
primordial, nomeada existência, mundo, horizonte. Portanto, o horizonte da existencialidade do corpo não mais se refere ao âmbito da objetidade, mas, ao domínio do fenômeno, da dimensão da corporeidade. Isto significa que o corpo assume um lugar ontológico, além do ôntico. Trata-se de uma compreensão que não está ligada a um fator externo e que se determina a partir de um modo de ser que é sempre o meu. Mas que modo de ser é esse? O pensador nos diz:

"[...] o corporar é co-determinado pelo meu ser homem no sentido da permanência ekstática em meio aos entes da clareia (e) o limite do corporar [...] é o horizontedo-ser no qual eu permaneço. Por isso, o limite do corporar se modifica constantemente pela mudança do alcance de minha estada." ${ }^{302}$

Esta parece mais uma daquelas sentenças enigmáticas. O pequeno trecho parece dizer que é o modo de abertura em que o homem se encontra que vai determinar a compreensão de corporeidade. O pensador faz menção à permanência da abertura do corporar, a qual não é constante e se modifica de acordo com o alcance da estada, ou seja, trata-se de uma permanência que se dá quando e na medida em que nela nos encontramos fincados, enraizados, ancorados. Caeiro, em outro de seus “Poemas Inconjuntos", escrito em 1915, parece expressar esse modo de ser quando diz:

As vezes ponho-me a olhar para uma pedra.

Não me ponho a pensar se ela sente. [...]

Outras vezes oiço passar o vento,

E acho que só para ouvir passar o vento vale a pena ter nascido.

Eu não sei o que é que os outros pensarão lendo isto;

Mas acho que isto deve estar bem porque o penso sem esforço,

Nem ideia de outras pessoas a ouvir-me pensar;

Porque o penso sem pensamentos,

Porque o digo como as minhas palavras o dizem. ${ }^{303}$

Mais uma vez nos deparamos com a visão do ver e a escuta totalmente imbricadas à relação do poeta com as coisas, com a corporeidade perpassada pela visão da pedra e pela escuta do vento. Não se trata de um olhar que pensa a pedra ou de um ouvir que pensa o vento. A relação do poeta com as coisas é de pura gratuidade, sem porquê ou para quê, sem de onde ou para onde. Não passa pelo pensar - ele pensa sem pensamentos! Isto significa que não há uma representação da coisa, não há conceitos elaborados sobre a coisa. Mas logo vem a pergunta: se não é uma

\footnotetext{
${ }^{302}$ HEIDERGGER, Seminários de Zollikon, p. 123.

${ }^{303}$ PESSOA, Obra Poética, p.235; idem, Obra Completa de Alberto Caeiro, p.91.
} 
representação, o que é? Nos colocamos diante da perplexidade da impossibilidade de uma resposta, do silêncio pleno, do assombro de nada pensar. Vislumbramos apenas o ver e o ouvir, a perfeita vibração da imanência do corpo da existência a tocar o poeta. Reformulando a pergunta: o que é então o nada pensar, o pensar sem pensamentos? E o ver e ouvir, o que são? Essas são questões fundamentais para a compreensão da corporeidade. Todavia, o salto para uma resposta nos afastaria da possibilidade de compreender a beleza do caminho. Deixemos as perguntas e toda a sua essencialidade para mais adiante. Retomemos o passo e o poema.

Caeiro nos fala de uma abertura que se interpõe ao modo como vemos e ouvimos. Trata-se de uma abertura momentânea que ocorre de acordo com a permanência do poeta naquele ato. Lembremos: Caeiro é poeta. Estamos, pois, permeados pelo ato de escrever. Na clareira da poesia, Caeiro fala como as palavras o dizem: ele é palavra, no dizer e pelo dizer é poema, mas é também pedra, vento, flor e tudo o mais que a permanência naquele horizonte, naquele mundo alcançar. É assim, na imanência do corpo da existência que o poeta sente o mundo. Enquanto atravessado pelo ato de escrever, Caeiro é mais poeta, e sendo mais poeta é mais ele mesmo. A compreensão heideggeriana de "que o limite do corporar se modifica constantemente pela mudança do alcance de minha estada" fala deste estado em que o poeta se encontra, um tal modo de ser que não o direciona para um fora, mas, para um âmbito no qual sua existência se encontra totalmente envolvida e tomada pela insistência no horizonte do ser. Por outras palavras: sua existência se encontra completa e perfeitamente incorporada ao seu modo de ser $\operatorname{ser}^{304}$, ao seu modo de ser-poeta.

Tomemos um outro poema. Logo na abertura de "O guardador de rebanhos", Caeiro relata o atravessamento por esse modo de ser que, ao se impor, revela uma estrutura totalizante de compreensão completamente integrada do corpo com a vida. Ele revela:

Eu nunca guardei rebanhos, Mas é como se os guardasse. Minha alma é como um pastor, Conhece o vento e o sol E anda pela mão das Estações A seguir e a olhar. [...]

Quando me sento a escrever versos

${ }^{304}$ Itálico nosso para distinguir a forma verbal da nominal. 
Ou, passeando pelos caminhos ou pelos atalhos,

Escrevo versos num papel que está no meu pensamento,

Sinto um cajado nas mãos

E vejo um recorte de mim

No cimo dum outeiro,

Olhando para o meu rebanho e vendo as minhas ideias,

Ou olhando para as minhas ideias e vendo o meu rebanho,

E sorrindo vagamente como quem não compreende o que se diz

E quer fingir que compreende. ${ }^{305}$

Os versos de Caeiro revelam um corpo engajado numa determinada situação: o ofício de escrever. É o próprio poeta que brada: “Quando me sento a escrever versos [...] Sinto um cajado na mão". Enquanto permanece atravessado, perpassado pelo ato de escrever, nele vige o vigor constituinte de sua existência. Caeiro tem a alma de um pastor que guarda em si a natureza, o sol e o vento - são as estações que guiam seu olhar. É um poeta que vê com a alma, que vê com aquilo que o anima, com aquilo que the dá vida. Sua alma é a própria poesia. Por isso, enquanto engajado, envolvido, entregue ao seu ser si-mesmo, enquanto tomado por esse modo de ser que é poesia, seu corpo é passagem para o poético. Nessa hora, apenas sorri vagamente como quem "quer fingir que compreende". Não há, pois, pensamentos ou alguma racionalização sobre a coisa, mas, apenas, o estar incorporado ao modo de ser poeta, ao ser si-próprio. Heidegger afirma que "o corporar tem esta notável relação com o si-mesmo." 306 Daí entendermos que a corporeidade não só deve passar pela compreensão de ser si-mesmo, mas, que há um nexo ontológico entre ambos, no qual o ser si-mesmo é condição fundamental para a dimensão da corporeidade.

Todavia, é o próprio poeta que nos interpela e lembra que nosso estar no mundo se dá, na maioria das vezes, de forma inautêntica e imprópria. Assim ele diz, em 1919:

[...] O "homem" vai andando com as suas ideias, falso e estrangeiro,

E os passos vão com o sistema antigo que faz pernas andar.

Olho-o de longe sem opinião nenhuma.

Que perfeito que é nele o que ele é - o seu corpo,

A sua verdadeira realidade que não tem desejos nem esperanças,

Mas músculos e a maneira certa e impessoal de os usar. ${ }^{307}$

\footnotetext{
${ }^{305}$ PESSOA, Obra Poética, p.203; idem, Obra Completa de Alberto Caeiro, p.31.

${ }^{306}$ HEIDERGGER, Seminários de Zollikon, p.124. Itálico do autor.

${ }^{307}$ PESSOA, op. cit., p.231; idem, op. cit., p.110.
} 
Seus versos nos advertem que somos estrangeiros, que andamos à margem das coisas e de nós mesmos. O poeta também nos fala de um certo automatismo que "faz pernas andar", de um sistema retrógrado, de um andar falso, impessoal e sem esperança, algo que foi tratado em nosso primeiro capítulo quando nos acercamos da técnica e do embotamento asfixiante em que o homem vive. Lembremos também que tal circunstância - o andar estranho da ausência de si - pode encaminhar o homem para uma tonalidade afetiva fundamental, a saber, a angústia, que, ao suspender todos os referenciais de mundo, abre a possibilidade de compreender o si-mesmo. Como acabamos de ver, com a experiência da angústia existencial, dáse um ultrapassamento, não na forma de um ir além ou para fora de uma imanência, mas, uma ultrapassagem que nos direciona ao âmago daquilo que nós mesmo somos. Nessa ultrapassagem, o Dasein se torna primeira e propriamente ele mesmo. ${ }^{308}$ Trata-se de uma experiência de transcendência - o nome do ser do ente. É ela que constitui a ipseidade, aquilo que é o seu mais próprio, sua constituição fundamental, a qual antecede qualquer comportamento. ${ }^{309} \mathrm{~A}$ questão da transcendência possui o privilégio de nela existir a possibilidade mais radical de individuação e singularização. ${ }^{310}$ Então, perguntamos: o que o corpo tem a ver com essa individuação mais radical que a transcendência traz? Caeiro responde, em 1919:

[...] Mas o corpo perfeito é o corpo mais corpo que pode haver,

E o resto são as sombras dos homens.

A miopia de quem vê pouco,

E o desejo de estar sentado de quem não sabe estar de pé.

Todo o cristianismo é um sonho de cadeiras.

E como a alma é aquilo que não aparece,

A alma mais perfeita é aquela que não apareça nunca -

A alma que está feita com o corpo

$\mathrm{O}$ absoluto corpo das coisas,

A existência absolutamente real sem sombras, sem mim,

A coincidência absoluta e inteira

de uma coisa consigo mesma. ${ }^{311}$

Trata-se, como o poema mesmo diz, de um corpo mais corpo que pode haver, de uma existência absolutamente real, da inteireza de uma coisa consigo mesma, lugar onde ser e ente se copertecem, coincidem exata e inteiramente, se amalgamam em

\footnotetext{
${ }^{308}$ Cf. HEIDEGGER, Introdução à Filosofia, p. 326.

${ }^{309}$ Cf. HEIDEGGER, "Sobre a Essência do Fundamento", in:

${ }^{310}$ Cf. HEIDEGGER, Ser e Tempo, p.78.

${ }^{311}$ PESSOA, Obra Completa de Alberto Caeiro, p. 105. , Os Pensadores, p.122.
} 
um corpo perfeito. Lembremos que per-feito vem do latim perfectio, que, por sua vez, vem do verbo perficere, o qual tem como prefixo o per- que, como vimos com o vocábulo ex-per-iência, significa atravessar; e o -ficere ou -facere que equivale a fazer. ${ }^{312}$ Portanto, com per-feito queremos aqui exprimir algo que se perfaz por completo, se consuma do início ao fim, algo que é totalmente perpassado por este modo de ser que é existência humana, que é vida. $\mathrm{Na}$ fala do poeta ainda ouvimos a palavra alma, que, como vimos, é anima, psyché, aquilo que faz uma coisa ser o que é. Em outro verso, Caeiro diz: "Há em cada cousa aquilo que ela é que a anima."313 Animar é dar ânimo, é dar vida, não como um algo a mais, mas no modo de ser que é a própria insistência de ser o que se é, a partir de si-mesmo. Por isso, como diz o poeta, a alma mais perfeita é aquela que não aparece nunca, pois perfaz o corpo, está feita com ele no "absoluto corpo das coisas". Aqui não há um dualismo, mas, a perfeição, a perfeita integração entre corpo e alma. Alma que é corpo, que é vida, que é existência. Não há, pois, o dentro ou o fora, mas, o salto para a transcendente-imanência ou a imanente-transcendência da cadência serena da possibilidade de ser, do aquiescer ao originário, de ser princípio finito de simesmo, daquilo que nasce a cada instante que uma nova possibilidade de ser se abre. Também não há o antes e o depois da transcendência, apenas o entre - um continuado permeio de estar inserido em um modo de ser que é abertura. Heidegger diz: "Esta transcendência nem vai para lá dele nem sobe para um outro, antes retorna a ele mesmo e para a essência da sua verdade. O ser, mede e percorre ele próprio este retorno, e é ele mesmo a dimensão deste." 314 Portanto, dentro/fora e antes/depois não são medidas para isso que é puro salto para dentro da própria vida, da própria existência, e cuja medida é dada pelo próprio ser. Emmanuel Carneiro Leão, na apresentação ao escrito de Heidegger, Introdução à Metafísica, nos brinda com uma belíssima compreensão sobre transcendência, que vai ao encontro do que acabamos de dizer e que não poderíamos deixar de transcrever na íntegra. Ele diz:

O termo "transcendência" indica essa excelência do homem de ultrapassar e superar a obscuridade do ente, com o qual se comunica constantemente em sua existência, iluminando-lhe o sentido, tornando-lhe transparente o ser na luz da Verdade. Já o fato de usar uma mesma palavra, a saber, luz, para significar tanto um fenômeno externo, a luz do sol, como um fenômeno interno, a luz da verdade,

\footnotetext{
312 ERNOUT et MEILLET, Dictionnaire Etymologique de la Langue Latine, p.210 e 497, respectivamente.

313 PESSOA, Obra Poética, p.245; idem, Obra Completa de Alberto Caeiro, p.119.

${ }^{314}$ HEIDEGGER, "Para quê poetas?", in: , Caminhos de Floresta, p.356.
} 
mostra de alguma maneira que o sol não se encontra de modo absoluto e exclusivo fora do homem, mas que primaria e originariamente o homem sempre existe no mundo, enquanto o transcende, e o mundo sempre transcende, enquanto nele existe. $^{315}$

Sabemos da dificuldade de compreensão do que seja transcendência para Heidegger. De um modo geral, nosso pensamento é levado para aquilo que se encontra além do humano, fora da imanência, ou mesmo para uma doutrina filosófica que tem como pilar uma revelação divina. Não se trata disso. Não obstante, ainda que saibamos o que a transcendência não é, não há como descrevêla, isso nos colocaria em uma posição de olhar o fenômeno de fora, em uma relação sujeito-objeto. Isto não é possível! O próprio pensador alemão nos diz que “a transcendência não pode ser nem revelada e nem compreendida por meio de uma fuga para o elemento objetivo." 316 Só podemos compreendê-la a partir de uma experiência essencial, a qual, em nosso caso, é ofertada pelo nada da angústia originária. Portanto, não se trata de uma compreensão formal dada por uma vivência factual, mas da própria estrutura de consumação do ser si-próprio, do encontro de si consigo mesmo, da concretude de uma singularização que se faz na gratuidade de ser: um ato da mais pura liberdade - sem porquê nem para quê - do puro vigor de existir que se dá na singeleza do mais simples, na vivência do extraordinário no ordinário, sendo isso a própria facticidade ${ }^{317}$ que perfaz a existência. É somente através deste ultrapassamento, também chamado de transcendência, que o Dasein pode se relacionar com o seu mais próprio e, a partir disso, com os outros e com o mundo. Lembremos apenas que quando nos referimos ao termo relação, não estamos, de forma alguma, pensando na relação entre duas coisas ou entre um sujeito e um objeto. O que Heidegger tem em mente para a essência deste vocábulo se acerca da ideia de uma aproximação, um interesse, uma resposta a um

\footnotetext{
${ }^{315}$ CARNEIRO LEÃO, "Itinerário do pensamento de Heidegger", in: HEIDEGGER, Introdução à Filosofia, p.14. Maiúscula do autor.

${ }^{316}$ HEIDEGGER, "A essência do fundamento", in: Marcas do Caminho, p.174.

317 É importante fazermos notar a distinção entre os termos factualidade e facticidade. Enquanto o primeiro diz respeito aos fatos, à objetividade das coisas, o segundo, se apresenta como horizonte, como abertura do sentido de ser, de existencialidade. Ainda que a facticidade se dê na factualidade, é preciso distinguirmos o aparecer da factualidade que, ao se mostrar como coisa, oculta o ser da coisa em sua existencialidade, ou seja, na factualidade só é coisa aquilo que aparece concretamente. Ela nada diz sobre a existencialidade. Esse esquecimento é reforçado ainda mais quando o sujeito se posiciona objetivamente diante da coisa e a coisa deixa de ser coisa para ser aquilo que o sujeito diz sobre ela; lugar em que, em última instância, tanto o sujeito quanto o objeto são colocados dentro do mesmo escopo objetivante. Sabemos, de antemão, das consequências trazidas pela relação sujeito/objeto, dentre elas, a mais grave, a redução do sentido de ser, intrínseco tanto à existência quanto à coisa.
} 
chamado. ${ }^{318}$ Trata-se, efetivamente, da relação consigo mesmo, com o seu outro, uma relação que transcende o mundo e abre o mundo como mundo; um salto para a abertura que perfaz a própria dinâmica de estruturação da existência, da possibilidade de ser-no-mundo, do ente em sua totalidade. Uma vez inserido neste modo de ser, quando se vê, já se vê desde o modo de transcendência, desde uma abertura. Caeiro escreve um poema em 1930, dentro da série intitulada "O pastor amoroso", onde ele conta de forma magistral esse movimento de ultrapassamento, um movimento que é puro dom e gratuidade. Mais uma vez, o mestre:

O pastor amoroso perdeu o cajado,

$\mathrm{E}$ as ovelhas tresmalharam-se pela encosta,

E, de tanto pensar, nem tocou a flauta que trouxe para tocar.

Ninguém lhe apareceu ou desapareceu.

Nunca mais encontrou o cajado.

Outros, praguejando contra ele, recolheram-lhe as ovelhas.

Ninguém o tinha amado, afinal.

Quando se ergueu da encosta e da verdade falsa, viu tudo:

Os grandes vales cheios dos mesmos verdes de sempre,

As grandes montanhas longe, mais reais que qualquer sentimento,

A realidade toda, com o céu e o ar e os campos que existem, estão presentes.

(E de novo o ar, que lhe faltara tanto tempo, lhe entrou fresco nos pulmões)

E sentiu que de novo o ar lhe abria, mas com dor, uma liberdade no peito. ${ }^{319}$

A primeira estrofe do poema fala de um sentimento de perda: o pastor perdeu o cajado, perdeu suas ovelhas. Não tocou a flauta. De tanto pensar, nada viu. Sabemos, por outro verso, que, para Caeiro, pensar é não compreender, é estar doente dos olhos. ${ }^{320}$ Estava perdido de si e do mundo. Nunca mais encontrou o cajado, a força do seu sentido de ser, do envio de sua própria vida, tão bem expressa no verso de outro poema: "Quando me sento a escrever versos [...] sinto um cajado nas mãos.” Mas eis que na segunda estrofe dá-se o salto. O pastor se eleva da encosta (e da verdade falsa!), se ergue acima do topo da colina e tem a visão do todo - eclode um mundo em sua finita concreção de possibilidade de ser. Tudo vê (e sente!). Vê os grandes vales, os campos e as montanhas. Vê o verde mais verde que se pode ver. Vê o céu e o ar a lhe encher os pulmões de liberdade e realidade. Vê o frescor da vida que se abre para o deixar-ser, para a pura possibilidade de um sentido de ser se fazer. Vê o próprio destinar da realidade humana em sua totalidade

\footnotetext{
${ }^{318}$ Cf. HEIDEGGER, Seminários de Zollikon, p.222.

319 PESSOA, Obra Poética, p.230; idem, Obra Completa de Alberto Caeiro, p.80.

${ }^{320}$ Cf. Ibidem, p.204-205; ibidem, p.34.
} 
a perfazer a gênese do mundo a cada nova possibilidade que se abre na (a)ventura de viver. Esta é a visão do ver: a visão de ver o que é visto. Portanto, isso que é transcendência é um modo de ser no qual estamos totalmente engajados, situados, integrados em um determinado horizonte, a partir de um modo todo próprio que determina e impulsiona inteiramente a existência humana - a radical abertura e liberdade da fluência de ser, na qual se consuma a vigência do ser. Transcendência, como diria Heidegger, é ser-no-mundo. ${ }^{321}$ Caminhemos um pouco mais.

Sabemos que o Dasein como ser-no-mundo é sempre aquele que se encontra em meio a outros entes e só se determina efetivamente a partir de uma inter-relação incessante com esse mundo. Sabemos também que a noção de mundo para Heidegger não se prende somente ao lugar de manifestação do conjunto de entes. O mundo, como vimos anteriormente, demarca o caráter ontológico de abertura do Dasein em sua existência, sua mais pura expressão, a própria abertura do ser: um modo de ser em que o Dasein se abre ao seu mais próprio e percebe que sendo se é. Na medida em que originariamente o Dasein é ser-no-mundo, há que se pensar a relação deste com o todo que o cerca, ou seja, todo e qualquer modo de ser do Dasein deve ser levado em consideração. Neste sentido, não só o ser-si-próprio, que se refere ao caráter de transcendência enquanto um projetar-se compreensivamente em direção ao mundo, é constitutivo do Dasein, mas o ser-com também assume um caráter originário na medida em que este sempre se ocupa de outros, razão pela qual devemo-nos lembrar que não há nisso um solipsismo ou subjetivismo e, muito menos, que se trata de uma outra visada que se abre a partir de uma tomada de consciência, mas, da compreensão da própria relação com o mundo à nossa volta; de ser-com os outros - com as coisas que nos encontram e que são cocriadoras de mundo na medida em que coparticipam da existência do Dasein como ser-nomundo. Nada além do que ser-uns-com-os-outros-no-mundo, sem, contudo, se referir à relação de um sujeito com o outro ou de um sujeito com um objeto, pois,

os 'outros' não significam todo o resto dos demais além de mim, do qual o eu se isolaria. Os outros, ao contrário, são aqueles dos quais, na maior parte das vezes não se consegue propriamente diferenciar, são aqueles entre os quais também se está." 322

Portanto, nada de uma relação apartada, mas, sim, de uma correlação, de um

${ }^{321}$ Cf. HEIDEGGER, Introdução à Filosofia, p.326.

${ }^{322}$ HEIDEGGER, Ser e Tempo, p. 174. 
entrelaçamento, de uma pertença, onde o ser-com deve ser entendido existencialmente na medida em que se trata de um mundo compartilhado. Heidegger, no escrito Introdução à Filosofia, de 1928, ainda complementaria a compreensão de 1927, de Ser e Tempo, afirmando que o Dasein “é cooriginariamente ser junto a..., ser-com e ser si-mesmo. Dessa maneira, ele é sempre uno e concomitante com os outros." 323 Isto significa uma coexistência, uma relação de encontro, de participação, de transpor-se para uma dimensão vital existencial que é a de ser partícipe e de insistir nessa participação - lembremos quando mais atrás tentávamos elucidar o modo de ser do homem como in-sistência ek-sistente do desvelamento do ser. Isto não significa uma perda, mas, ao contrário, nesta copertença se conquista uma unidade originária toda própria. Entretanto, como podemos pensar esse engajamento da corporeidade como coexistência? Como pensar essa integração totalizante do corpo?

Será através do o poema IX, de "O guardador de rebanhos", escrito em 1914, que seremos levados ao entendimento do corpo em sua totalidade. Caeiro descreve a expressão mais radical e originária da corporeidade explicitada a partir de uma experiência inserida na existência. Seus versos nos fazem entender que nosso estar no mundo é totalmente perpassado por uma experiência de sentido, na qual já estamos sempre inseridos. Entretanto, é preciso lembrar que isso que se mostra e vem ao nosso encontro não é, de forma alguma, uma captação sensorial. A visão, a audição, o olfato, o gosto e o tato não são suficientes para alcançar o outro e com ele constituir uma correlação. Não que eles não estejam presentes, o problema é que o fisiológico está sempre atravessado por uma objetivação e não dá conta da corporeidade que, em seu caráter ontológico, é sempre anterior e diz respeito a uma abertura pré-compreensiva de si mesmo e do mundo. Isto significa que não é o fisiológico aquilo que permite explicitar a relação com o outro, não é o corpo físico que faz essa mediação, mas, é o próprio modo de ser que é abertura que estabelece uma relação de copresença com os outros. Ouçamos com atenção:

Sou um guardador de rebanhos.

O rebanho é os meus pensamentos

E os meus pensamentos são todos sensações.

Penso com os olhos e com os ouvidos

E com as mãos e os pés

${ }^{323}$ HEIDEGGER, Introdução à Filosofia, p.356. 
E com o nariz e a boca.

Pensar uma flor é vê-la e cheirá-la

E comer um fruto é saber-lhe o sentido.

Por isso quando num dia de calor

Me sinto triste de gozá-lo tanto.

E me deito ao comprido na erva,

E fecho os olhos quentes,

Sinto todo o meu corpo deitado na realidade,

Sei a verdade e sou feliz. ${ }^{324}$

A pátria de Caeiro é o sentir. É a sensação o seu elemento mais próprio, aquilo que determina sua morada no mundo. O pastor-poeta guarda rebanhos-pensamentos, os quais são todos sensações. Para Caeiro, pensar é sentir. Ele mesmo diz que pensa com os olhos e com os ouvidos, com as mãos e os pés, com o nariz e a boca. Estão aqui presentes todos os órgãos dos sentidos. Entretanto, é interessante notarmos que não é pura e simplesmente da visão, da audição, do tato, do cheiro ou do paladar que o poeta está a falar. $\mathrm{O}$ que os versos ressaltam é a exata experiência de sentir aquilo que a coisa é, tal como ela é, em sua imediatidade, em seu todo, absoluto, nada a mais nem a menos do que a própria coisa. Nada a mais nem a menos do que o próprio sentir, do que a própria sensação. Nada a mais nem a menos do que a própria realidade. Isto que é a sensação já é sempre no mundo e desde um sentido. Por isso, num dia de calor, ele deita seu corpo na relva, fecha os olhos e sente a realidade. É exatamente pelo fato de que o poeta sente o "corpo deitado na realidade" que ele "sabe a verdade e é feliz". Isto significa que o saber não está relacionado a um conhecimento científico-epistemológico, e nem a verdade é aqui uma mera correspondência ou adequação. Sabendo a verdade Caeiro é feliz. Felicidade é, pois, a própria completude, a perfeição no sentido do que foi dito anteriormente. Aqui encontramos a mais pura expressão de uma experiência do real, totalmente perpassada pelo corpo, pela corporeidade. Busquemos alguma compreensão.

Pessoa, um dos comentadores de Caeiro, dedica algumas páginas em seus escritos de prosa à questão da sensação, do sensacionismo. Logo no prolegômeno de suas Obras em Prosa, Pessoa conta que, na origem grega, "a sensação da realidade era direta, [...] imediata." ${ }^{325}$ Isto significa dizer que entre a coisa e a

\footnotetext{
${ }^{324}$ PESSOA, Obra Poética, p.212; idem, Obra Completa de Alberto Caeiro, p.47.
}

${ }^{325}$ PESSOA, Obras em Prosa, p.424. 
sensação "não se interpunha uma reflexão, um elemento qualquer estranho ao próprio ato de sentir." ${ }^{26}$ Ele nos alerta para o fato de que foi a noção de alma, considerada como distinta e superior ao corpo, que acabou por tornar as coisas menos importantes e, com isso, a própria noção de Natureza. Caeiro é, por assim dizer, o fundador do movimento sensacionista, o criador da poesia da Natureza, algo que o faz afirmar que ele é "um intérprete da Natureza"327, "o único poeta da Natureza" 328 e, até mesmo, "o Descobridor da Natureza"329. Para o sensacionismo, a sensação é a única realidade da vida. Isto significa que tudo que é e há é perpassado pelo sentir. Entretanto, isso não quer dizer que o sentir é um só, homogeneizado, unidimensionalizado. Não! Como Pessoa mesmo diz: “As coisas devem ser sentidas tais como são." ${ }^{330}$ Isto significa dizer que Caeiro busca ver nas coisas as próprias coisas. Poderíamos listar incontáveis passagens e inúmeros momentos nos quais Pessoa faz menção ao sensacionismo. Todavia, não cremos que um inventário dos mesmos nos ajudaria na compreensão disso que é a sensação. Para tal, precisamos nos colocar na posição de compreensão do horizonte de Caeiro, seu mundo, sua dimensão. Não cremos que o poeta da Natureza esteja a pensar a sensação como algo da ordem de estímulos nervosos, operações que se passam em nosso córtex cerebral ou coisas do gênero. Não que tudo isso não ocorra, mas neurônios, impulsos e sinapses são todos da ordem da fisiologia, estão relacionados ao biológico e são, portanto, tardios.

É importante também fazermos notar que Caeiro é pagão. ${ }^{331} P \bar{a} g \bar{a} n u s$, em latim, significa camponês, rústico. Vem de pāgus, que é relativo ao campo, à área fora da cidade. ${ }^{332}$ Somente mais tarde é que o paganismo se referirá às tradições religiosas greco-romanas politeístas. Seu paganismo é marcado pela ausência dos conceitos de infinito, ilimitado e subjetivo tão presentes na interioridade cristã e

\footnotetext{
${ }^{326}$ PESSOA, Obras em Prosa, p.424.

${ }^{327}$ Ibidem, p.220; PESSOA, Obra Completa de Alberto Caeiro, p.61.

${ }^{328}$ Ibidem, p.237; ibidem., p.93.

${ }^{329}$ Ibidem, p.226; ibidem., p.70.

${ }^{330}$ PESSOA, Páginas Íntimas e de Auto-Interpretação, p. 350.

${ }^{331}$ É Ricardo Reis que, no prefácio sobre Caeiro, nos fala que a obra do mestre compreende uma reformulação total da essência do paganismo. Reis fala de um paganismo absoluto, sem qualquer ramificação, tal como nem os gregos puderam pensar, e que Caeiro é mais grego que os próprios gregos. (Cf. PESSOA, Obras em Prosa, p.113-115). Álvaro de Campos reforça esta compreensão ao afirmar: "O meu mestre Caeiro não era um pagão: era o paganismo." (Ibidem, p.108). Campos entende que não havia em Caeiro uma explicação para o paganismo, mas, consubstanciação.

332 Cf. ERNOUT; MEILLET, Dictionnaire Etymologique de la Langue Latine: Histoire de Mots, p.475-476.
} 
intimismo moderno. Caeiro é grego! Marca seu paganismo o assentimento do limite e do finito. Fala-se inclusive de um objetivismo. Todavia, não entendemos esse objetivismo em oposição a um subjetivismo. O objetivismo de Caeiro se explica pelo fato de que ele se põe diretamente na própria coisa, lugar em que o sentir é inseparável da imagem, é imediato, é sempre já a sensação que perfaz o corpo. Por isso, é preciso nos distanciarmos da ideia de objetividade/subjetividade e retomarmos a compreensão de transcendência que se dá sempre como irrupção, salto, inserção.

Caeiro é o poeta da sensação, o poeta do sentir. Sua devoção ao sentir é tamanha que ele assim nos ensina:

Procuro dizer o que sinto

Sem pensar o que sinto

Procuro encostar a palavra à ideia

E não precisar de um corredor

Do pensamento para as palavras.

O poeta busca o encontro da ideia com as palavras. Diretamente. Sem pensar. Ele diz o que sente. Seabra entende que a poética de Caeiro está tão intimamente afinada com a sua sensibilidade, que o poeta deseja "colmatar a brecha, a distancia que vai da sensação às palavras, sem passar pelo istmo do pensamento." ${ }^{333}$ Para o intérprete, há nele uma identificação do sentir com as coisas "que se poderá dizer fenomenológica, operada através da eliminação de todos os vestígios da subjetividade." ${ }^{334}$ Mas, o que é isto, o sentir? Para o grego, a sensação é aísthesis. No latim, vem do verbo sentire ${ }^{335}$ e equivale a sentir, perceber, captar, compreender, entender; experimentar uma sensação ou um sentimento. Heidegger diz que aísthesis é "a simples percepção sensível de alguma coisa." 336 A sensação está também relacionada com o perceber, o compreender, o conhecer, o pensar, o captar, o apreender; o ser sensibilizado, atingido, perpassado, atravessado por algo. Tudo isso de uma maneira toda própria. Trata-se de um modo de se relacionar com as coisas que nada tem de passividade, como acontece com os cinco sentidos. É sempre bom relembrarmos que a apreensão sensível sobre a qual nos reportamos, nada tem de uma representação já fixada em uma interpretação fisiológica, a qual

\footnotetext{
333 SEABRA, Fernando Pessoa ou o Poetodrama, p.69.

334 Ibidem, p.92.

${ }^{335}$ ERNOUT et MEILLET, Dictionnaire Etymologique de la Langue Latine, p.614.

${ }^{336}$ HEIDEGGER, Ser e Tempo, p.73.
} 
não nos permite uma experiência aprofundada do fenômeno. Portanto, no sentir da sensação não nos referimos a uma passividade, como algo que está parado, nem tampouco a uma atividade, ligada ao movimento, como usualmente depreendemos. A ideia de passividade e atividade assim pensadas limitam nosso entendimento quando nos reportamos aos fenômenos humanos constituídos de liberdade. Vejamos uma ótima compreensão para isso. Harada, em Coisas, velhas e novas, diz:

Nos fenômenos dos entes vivos e nos fenômenos humanos, passividade e a atividade não são propriamente duas coisas opostas. Elas são por assim dizer dois momentos recíprocos de uma e mesma dinâmica. Na dinâmica da vida e da liberdade, o momento passivo é como que o fundamento do momento ativo e passividade ali é como silêncio de fundo onde toa e repercute o som (= atividade). É como a abertura de possibilidade do todo (= passividade), dentro da qual surgem as diferentes concreções (= atividades). É que toda e qualquer atividade, primeiro deve ser possibilitada através de uma recepção prévia do todo, do horizonte, do espaço da possibilidade, dentro do qual se tornam possiveis e atuais as diferentes e variegadas atividades. ${ }^{337}$

O autor nos fala de uma dinâmica que é perpassada tanto pela passividade quanto pela atividade. Não há uma oposição, mas, uma complementaridade, na medida em que uma é base para a outra. É na passividade receptiva que a atividade encontra a sua possibilidade de concreção, e é na abertura da passividade que existe a possibilidade do salto para o todo. Segundo Harada, o lugar da passividade é o fundamento da atividade - um não é sem o outro, se copertecem. Notemos que Harada usa a imagem do silêncio de fundo, lugar em que a ausência de som não siginifca um espaço vazio, oco, mas, ressoa a própria possibilidade de som. A passividade não fala de um espaço de privação e de carência, mas, ao contrário, fala de um lugar pleno de possibilidades de sentido, ou como ele diz: " [...] prenhe de esboços de consumação vindoura." ${ }^{338}$ É, pois, na passividade receptiva que existe a disponibilidade de abertura plena de porvires futuros. É para a condução da realização do porvir que o sentir nos envia. Fazemos notar que o sentido de envio, de buscar um caminho, presente no substantivo alemão Sinn (sentido) e no verbo sinnen (sentir), é encontrado na flexão antiga sinnan, que tem como significado: viajar, ir (lembremos aqui do já visto fahren, de Er-fahrung (experiência), que também equivale a viajar!). Sentir significa, então: seguir, enviar-se, se dirigir por uma orientação prévia plena de caminho, repleta de sentido. Significa ir atrás do

\footnotetext{
${ }^{337}$ HARADA, Coisas, velhas e novas, p.31. Itálico do autor.
}

${ }^{338}$ Ibidem, p.31-32. 
vestígio, seguir o rastro, investigar. Sentir é, pois, uma dinâmica perpassada tanto pelo receptivo quanto pelo ativo, os quais nos orientam para uma possibilidade de desvelamento. Podemos, por ora, dizer que compreendemos a sensação como uma receptividade ativa. Vimos que a sensação se relaciona ao ser atravessado, perpassado por algo e que essa receptividade possui uma cifra de atividade. Mas, ainda, como podemos entender a relação do pensar com a sensação? Dissemos que, para Caeiro, pensar é sentir. Como isso é possível? Alguns passos a mais fazem-se necessários.

No livro Introdução à Metafísica, escrito em 1935, no subcapítulo intitulado “Ser e Pensar”, Heidegger nos fala algo como: “[...] onde o ser impera, lá também impera e acontece, como pertencente a esse vigor do ser, a percepção, o pôr-se em posição receptora daquilo que está em si mesmo constante e se mostra." 339 Isto significa dizer que o reino do ser não pode ser entendido sem o co-reino da percepção. O filósofo alemão nos fala que esta pertença se dá através de uma experiência que torna evidente, àquele que a perpassa, que o ser do homem só pode ser determinado a partir do acontecimento que fudamentalmente une o ser e o perceber. Notemos que, neste escrito, apesar de o título do capítulo ser "Ser e Pensar", o pensador usa o vocábulo percepção. Nos detenhamos um pouco na origem do vocábulo. Percepção, em latim, se diz percipere. É um termo formado pelo prefixo per, que significa atravessar, e pelo verbo capere, que significa pegar, agarrar. Percipere fica compreendido como notar, compreender ${ }^{340}$, deixar chegar aquilo que se mostra, que aparece. Trata-se de um deter receptivo. Todavia, é sempre importante reiterarmos que não devemos pensar de forma cristalizada entendendo a percepção como uma faculdade ou um mero dado psíquico. Nem, tampouco, acreditemos que o filósofo alemão entenda o pensar como percepção no sentido habitual de apreender dados. Na realidade, os vocábulos que norteiam o pensar de Heidegger são sempre os mesmos: noûs e noê̂n, que significam percepção e perceber, respectivamente. Para ele, através de uma conduta atenta e livre do habitual, quando nos aproximamaos do noeîn percebemos que a tradução desse vocábulo por pensar não alcança a essência desta palavra. A tradução de noeîn por perceber é muito mais acurada. Como, então, podemos entender este perceber?

\footnotetext{
${ }^{339}$ HEIDEGGER, Introdução à Metafisica, p.162-3. Itálico nosso.

340 ERNOUT et MEILLET, Dictionnaire Etymologique de la Langue Latine, p.497 e 95, respectivamente.
} 
Assim como a sensação, trata-se de compreendermos a percepção como uma recolha, uma receptividade que, no entanto, é ativa, na medida em que aquilo que é percebido no noeîn nos interessa. Segundo o filósofo, a forma substantivada de noeîn - nóos, noûs - nos encaminha a perscrutar um sentido mais profundo e fazer isso de coração; algo que em nada se assemelha àquilo que mais tarde ficou entendido por razão. Daí resulta que o noeîn pode também significar o farejar, cujo escopo semântico associa-se ao pressentir. Todavia, numa dimensão puramente lógica, esse pressentir perdeu-se de seu sentido primevo que originalmente se acercava da ideia de que algo vinha até nós, nos sobrevinha, e, desse modo, se oferecia à atenção para que aí o retivéssimos, como numa dimensão ativa de captura. Nesta apreensão não havia uma dominação, o noeîn não se apoderava daquilo que era apreendido, ele apenas guardava em atenção, e, por isso, era uma salvaguarda, algo que se guardava com o coração. Não se trata, pois, de um perceber que tem por traz um sujeito, um eu ou uma consciência. Já vimos que isto é tardio, epigonal e nada tem de originário. O pensador alemão usa o vocábulo Vernehmen para esta capacidade intangível de receber-perceber aquilo que chega até nós, o qual se refere ao fenomenológico imediato, não-teorético. Isto significa que a base da percepção, daquilo que vemos e de todo o aparecer, é tão somente a apreensãopercepção-sensível, que também agrega a ideia de escuta. ${ }^{341}$ Trata-se de um acontecimento em que "o homem mesmo chega ao ser" 342 - lugar em que se realiza um acontecimento histórico: o envio do homem como guardião do ser; momento em que este acontecimento se apodera e toma posse do homem para que ele venha a ser o homem que é. Sabemos, entretanto, que toda esta questão está envolta por uma complexidade, cuja dimensão atravessou o pensamento ocidental. Lembremos das palavras de Aristóteles, na Metafisica: “Assim como os olhos dos pássaros da noite se comportam diante da luz resplandecente do dia, também a percepção que é própria da nossa essência se comporta diante do que a partir de si mesmo é o mais resplandecente de todos." ${ }^{343}$ Entendemos, com isso, que a questão do noûs está marcada por uma grande dificuldade e, porque não dizer, por uma impenetrabilidade que é refratária ao pensamento racional. Toda essa questão só se deixa acessar através de uma experiência. Palavra que, como vimos anteriormente,

${ }^{341}$ Cf. HEIDEGGER, Zollikon Seminars, p.4.

${ }^{342}$ HEIDEGGER, Introdução à Metafisica, p.165.

${ }^{343}$ ARISTÓTELES apud HEIDEGGER, Que Chamamos Pensar? [inédito], p.92. 
possui um estatuto bastante elevado no vocabulário heideggeriano. Entendemos também que a questão do noûs está atrelada ao lógos, na medida em que ambos fazem parte de uma comunidade interna de essencialização. Entretanto, não nos deteremos neste tema agora, no próximo capítulo nos voltaremos para a linguagem propriamente dita. Por ora, nos interessa entender a copertença entre nôิs e aisthesis, entre percepção e sensação.

É interessante notarmos que Aristóteles tenha feito uma analogia entre os olhos dos pássaros da noite, cegos pela luz do dia, e a percepção do noûs que, apesar de se relacionar com aquilo que é mais evidente, não pode ser vislumbrado. Isto denota que precisamos entender a visão, o ter olhos para ver, a partir de uma outra chave. Ter olhos para ver é totalmente diferente de avistar algo. Avistamos muito e vemos pouco, diz Heidegger. Ter olhos para ver significa: "obter um aspecto daquilo, a partir do qual é visto propriamente [...]." ${ }^{344}$ Parece-nos vago ainda. Como podemos obter um aspecto de algo? Ortega y Gasset abre uma perspectiva no $§ 18$, intitulado "El sensualismo en el modo de pensar aristotélico", do escrito La Idea del Principio en Leibniz y la Evolución de la Teoría Deductiva, que parece ir na mesma linha do pensamento de Heidegger quando diz que, para Aristóteles, "a verdade sobre as coisas se encontra em sua máxima proximidade para com elas, e a máxima proximidade de uma mente com a realidade é a sensação." 345 O autor entende que a sensação é a faculdade noética fundamental da doutrina aristotélica e que o seu sentido perdeu força, na medida em que a noção de sensação ficou atravessada por uma compreensão que insiste em nos remeter aos órgãos dos sentidos. Na verdade, a sensação exerce muitas funções, as quais usualmente são todas atribuídas à razão. Todavia, a noção de sensação em Aristóteles é muito mais ampla. Para o filósofo grego, sensação é fundamentalmente conhecimento de algo (gnôsis tis), uma vez que nela encontramos a capacidade de perceber, apreender e julgar. Ortega y Gasset nos conta que, na tradução de Aristóteles para o espanhol, onde o tradutor escreveu julgar, como uma das características da sensação, Aristóteles escreveu sentir. Trata-se, segundo o autor, de uma mudança fundamental, pois enquanto o julgar se atém à emissão de um juízo, um falar sobre algo, o sentir capta aquilo que é, sem, entretanto, classificá-lo ou catalogá-lo.

\footnotetext{
${ }^{344}$ HEIDEGGER, O Princípio do Fundamento, p.74.

345 ORTEGA Y GASSET, "El sensualismo en el modo de pensar aristotélico", in: La Idea del Principio en Leibniz y la Evolución de la Teoría Deductiva, p.59. Tradução nossa.
} 
Todavia, como em Aristóteles a sensação exerce várias funções intelectuais que, na maioria das vezes, são atribuídas tão somente à razão, ela acabou sendo traduzida por juízo, só que se trata de um juízo pré-predicativo. E logo indagamos: o que é um juízo pré-predicativo? O pensador espanhol esclarece esta compreensão fazendo uma comparação com a análise sobre a percepção tratada por Husserl, no livro Erfahrung und Urteil, preparado para publicação antes de sua morte. Ele diz que Husserl, de maneira muito mais desenvolvida do que Aristóteles, mostra que todo o enunciado expresso no ajuizamento está de forma oculta e explícita na percepção. Logo, o mais justo seria traduzir aisthesis por "intuição sensual ou sensível”, um entendimento dado pelo sentir. Ela é o primeiro conhecimento de algo, por isso é chamada de faculdade noética, o mais "puro" inteligível - noetón que o entendimento pode conceber. O requinte deste pensamento é reforçado com a ideia de que a alma é compreendida através da percepção sensível e do intelecto como princípio de conhecimento e discernimento. ${ }^{346}$ Assim, se para o filósofo grego a sensação é essencialmente conhecimento e discernimento, podemos depreender que conhecer é perceber, apreender e sentir. Heidegger também se detém nesta questão ao afirmar que Aristóteles jamais defendeu a ideia de que o juízo fosse o lugar originário da verdade - entendendo originário como aquilo que vem primeiro, o lugar de onde algo provém, e verdade como aquilo que se mostra. ${ }^{347}$ Com isso, o pensador alemão entende que, para Aristóteles, o juízo não fala do lugar de onde se origina aquilo que se mostra em sua imediatidade, mas é a sensação capaz deste desvelamento. Na sensação se é perpassado por um entendimento, pela compreensão de algo, sem nada pensar, predizer ou predicar sobre o que se sente, se assim podemos dizer. Isto significa que o sentir é inseparável da imagem e desta como mostrar-se, como um aparecer. É, pois, a percepção-sensação o revelar-se e o dar-se de uma coisa em sua imediatidade, é o ver e o ouvir desde a coisa mesma. Ouçamos o mestre Caeiro, nos versos de 1918:

O que ouviu os meus versos disse-me: Que tem isso de novo?

Todos sabem que uma flor é uma flor e uma árvore é uma árvore.

Mas eu respondi, nem todos, ninguém.

Porque todos amam as flores por serem belas, e eu sou diferente.

E todos amam as árvores por serem verdes e darem sombra, mas eu não.

$\mathrm{Eu}$ amo as flores por serem flores, diretamente.

\footnotetext{
${ }^{346}$ Cf. ARISTÓTELES, De Anima, p.122. (III, 9, 432a15)
}

${ }^{347}$ Cf. HEIDEGGER, Ser e Tempo, p.297. 
Eu amo as árvores por serem árvores, sem o meu pensamento $[\ldots]^{348}$

Os versos nos falam de um modo diferenciado de compreender as flores, as árvores e todas as coisas. A relação do poeta com o todo que o cerca é direta. Portanto, determinações de causalidade, finalidade ou temporalidade não são levadas em conta quando a percepção-sensação está em jogo. Caeiro não vê a flor por sua beleza ou a árvore por sua sombra. Não há aqui uma objetivação da natureza. O poeta sente a flor ou a árvore em sua existência - diretamente - como ele mesmo diz em outro poema: "Eu nem sequer sou poeta: vejo." 349 Trata-se de um modo de se relacionar com as coisas que é abertura, um modo em que o poeta, ao sentir, entra na própria coisa, e, com isso, a coisa se mostra nela mesma, em seu modo próprio de ser, em sua natureza. Para Heidegger, a verdade da visão das ideias e da aísthesis é um desencobrimento originário. ${ }^{350}$ Seabra, em Fernando Pessoa ou o Poetodrama, chama o lugar em que a criação poética recupera a visão originária de visão primitiva das coisas. ${ }^{351}$ Isto quer dizer que não há um pensar sobre a coisa, um fazer conjecturas ou emitir juízos, mas, apenas o sentir, a visão do ver e a escuta, os quais levam o poeta a entrar em sintonia com a coisa, transportando-o para a sua dimensão, seu horizonte, de modo que a coisa apareça nela mesma, de forma originária. Fogel, em Sentir, Ver, Dizer, esclarece que "sentir e perceber, sentir e ver, aísthesis e noûs constituem um único e mesmo ato." ${ }^{352}$ A aísthesis é, pois, um sentir que já é sempre perceber, ver. Trata-se, como diz o autor, de um único e mesmo acontecimento que se dá na singularidade do instante, o qual, em se realizando no homem, deixa-ser, aparecer, faz-se o mostrar de algo como algo. Caeiro diz que sua relação com as coisas se dá sem pensamentos. Entendemos, com isso, que o poeta esteja a se referir a um pensar que sente, originário e prenhe de sentido, um pensar que compreende antecipadamente a coisa como coisa, de forma originária, "em seus modos primários de existência e realidade" ${ }^{353}$, uma vez que “toda visão pré-predicativa do que está à mão já é em si mesma um em compreendendo [...], (e que) o ver dessa visão já é sempre um compreender." ${ }^{354}$ Por outras palavras: a percepção-sensação já traz em si uma compreensão de tudo aquilo

\footnotetext{
348 PESSOA, Obra Poética, p.243; idem, Obra Completa de Alberto Caeiro, p.104.

${ }^{349}$ Ibidem, p. 235.

${ }^{350}$ Cf. HEIDEGGER, Ser e Tempo, p.297.

${ }^{351}$ Cf. SEABRA, Fernando Pessoa ou o Poetodrama, p.95.

${ }^{352}$ FOGEL, Sentir, Ver, Dizer, p.47. Grifo do autor

${ }^{353}$ HEIDEGGER, op. cit., p.409. Itálico nosso.

354 Ibidem, p. 210.
} 
que se mostra antes de toda e qualquer afirmação à respeito. Portanto, na percepçãosensação não está arrolada a pergunta “o que é isto?”, que conduz para a fixação da coisa como um objeto. Não há uma determinação ou mesmo qualquer outra pergunta. Na percepção-sensação apenas se compreende, na medida em que já se está inserido dentro de um círculo de sentido. Fogel reforça esta ideia ao afirmar que "todo sentir já é, de algum modo, estruturado, organizado, e, por isso, revelador ou mostrador de um sentido, de uma significação, da qual ele é a concretização, a realização" ${ }^{355}$, ou seja, na percepção-sensação já se é transpassado por uma unidade de sentido, por um lógos, o qual instaura o ver-aparecer.

Caeiro será o mestre, o guardador das sensações-pensamentos-rebanhos que testemunha a simplicidade do mundo e nos oferta o desvelar dos montes e dos vales, das árvores e flores, dos rios e pedras, da natureza, do próprio mistério da existência. Ele diz, em 1914:

O que nós vemos das coisas são as cousas.

Por que veríamos uma cousa se houvesse outra?

Por que é que ver e ouvir seria iludir-nos

Se ver e ouvir são ver e ouvir?

O essencial é saber ver,

Saber ver sem estar a pensar,

Saber ver quando se vê,

E nem pensar quando se vê

Nem ver quando se pensa.

Mas isso (tristes de nós que trazemos a alma vestida!),

Isso exige um estudo profundo,

Uma aprendizagem de desaprender $[\ldots]^{356}$

O poeta se refere aqui a um saber ver que é simplesmente sentir, ao assentar-se na coisa como coisa, tal e qual ela se mostra em sua imediatidade. Só que para isso, é preciso não ter a alma re-vestida e engessada por tantas certezas e convicções, por tantos hábitos e automatismos, por tantas opiniões e consensos, os quais embotam a nossa visão das coisas e nivelam de modo acachapante a realidade. É preciso estar despido. É preciso aprender a desaprender para poder ver (e sentir!) com o frescor de ver (e sentir!) pela primeira vez. Trata-se de um desaprender que nos põe direta e imediatamente numa dimensão extraordinária que pensa sem pensamentos! Caeiro é o olho que sente, a escuta que sente, o corpo que sente, nada além e nada

${ }^{355}$ FOGEL, Sentir, Ver, Dizer, p.215. Itálico do autor.

${ }^{356}$ PESSOA, Obra Poética, p.217; idem, Obra Completa de Alberto Caeiro, p.56. 
aquém do que a própria imanência de cada coisa em seu desvelar de coisa. Tratase, como vimos anteriormente, de sentir a realidade, de se colocar nas coisas, sentilas como coisas que são, nem por fora e nem por dentro, mas, engajado, integrado àquela realidade. Enquanto ali se está, se é um. Trata-se de uma integração temporária onde no final se volta à singularidade própria de cada um, mas atravessado pela experiência daquilo que viveu enquanto engajado, integrado. Nos referimos aqui a uma visão de mundo livre de qualquer subjetividade e nada fácil de ser alcançada. Por tal enlevamento Caeiro é proclamado mestre, o mestre do aprender que

“[...] O único sentido íntimo das cousas

É elas não terem sentido íntimo algum [...]”357

Por isso, desaprender para poder ver nas coisas somente coisas. É Caeiro que nos ensina o sagrado que há na própria existência de cada coisa, sem porquê nem para quê, e nos reconcilia com o mundo e com a vida. Portanto, aísthesis-noûs, sentirperceber, diz o mesmo que sentir-ver-ouvir: a corporeidade em perfeita sintonia e sincronia com a própria coisa - corpo se fazendo corpo ao mesmo tempo em que a realidade se faz realidade. O corpo assume, assim, o lugar e a hora desse encontro com o mundo, o lugar e a hora da instauração de horizontes de sentido, o lugar e a hora em que sua estrutura totalizante se encontra completamente fincada na insistente permanência da existência historial humana. ${ }^{358}$ Isso é corpo. Isso é corporeidade.

Gostaríamos de partilhar uma belíssima reflexão sobre corporeidade trazida por Hermógenes Harada, no texto intitulado "Fenomenologia do Corpo", no qual o autor nos oferece a imagem do velho pescador de Hemingway. Entendemos que esta experiência é capaz de atravessar o humano de tal forma que constitui o processo historial de toda uma vida. Segundo Harada, a figura do velho pescador revela um corpo engajado numa determinada situação. $O$ vento, o mar, as tormentas, a vida e a morte, os êxitos e fracassos, todas essas situações formam os elos inevitáveis da facticidade que oprimem o velho pescador por todos os lados. Sua obstinação e persistência em cada adversidade o faz mergulhar mais fundo em seu destino. Quer suporte ou não, ele está rigorosamente ancorado na situação de

\footnotetext{
357 PESSOA, Obra Poética, p.207; idem, Obra Completa de Alberto Caeiro, p.38.

358 Espaço e tempo aqui entendidos dentro da dinâmica de inauguração de tudo quanto pode ser e haver.
} 
pescador. Este processo que forja a sua história faz surgir seu corpo, um corpo velho e encarquilhado que sempre experimenta o mar como situação, como horizonte, no corpo de sua vida. O que se segue nessa imposição do mar sobre o pescador, é que o pescador se torna a cada luta, sofrimento ou alegria, mais pescador, ou seja, ele cresce junto com o mar em seu ser si-mesmo. Nele, tudo são marcas do mar. Como horizonte e dimensão, o mar e o pescador não estão apartados, isto é, o corpo do pescador e o mar não se põem objetivamente um para o outro, mas, sim, como abertura originária na medida em que nela se vive e se insere enquanto existência. O corpo do velho pescador, podemos dizer, incorporou o mar, integrou-se a ele, também se faz mar a cada vez, ao mesmo tempo em que o mar também se faz pescador. Nesta relação, abre-se um mundo, um modo possível de ser vida. Tratase de uma experiência que irrompe, ilumina e se faz vida encarnada, incorporada num fazer que é também história e destino de tudo o que se pode ser. A corporeidade assim compreendida não é outra coisa senão vida humana, na qual a ideia de corpo e alma são conceitos limitantes para aquilo que é a própria riqueza e exuberância da vida. Sabemos que esta não é uma compreensão fácil. O fenômeno do corpo entendido a partir da existência é algo singular, nada perceptível ou materialmente apreensível, mas, absolutamente fundamental, pois fala da saga da vida humana elevando-se em júbilo e alegria como pura gratuidade. Em nota encontrada, intitulada "Palavras de Pórtico", Pessoa escreve:

Navegadores antigos tinham uma frase gloriosa: "Navegar é preciso; viver não é preciso." Quero para mim o espírito [d] esta frase, transformada a forma para casar com o que eu sou: Viver não é necessário; o que é necessário é criar. Não conto gozar a minha vida; nem gozá-la penso. Só quero torná-la grande, ainda que para isso tenha de ser o meu corpo e a (minha alma) a lenha desse fogo. Só quero torná-la de toda a humanidade; ainda que para isso tenha de a perder como minha. $[\ldots]^{359}$

Este pequeno trecho, que abre a introdução da obra poética de Fernando Pessoa, nos dá a dimensão da corporeidade inserida radicalmente em sua entrega e

\footnotetext{
359 PESSOA, Obra Poética, p.15. O trecho destacado encontra-se em nota solta e não assinada, porém é atribuído a Pessoa, que teria descoberto a frase num artigo de Joseph Addison, publicado na revista The Spectator, de 1712, e teria incluído o mesmo em uma coletânea. A mesma ideia foi trabalhada também no Livro do Desassossego, nos trechos 124, 125, 306 e na "Sinfonia da noite inquieta". Sabemos, em nota de Richard Zenith, que Maria Aliete Galhoz, organizadora da obra poética de Fernando Pessoa, descobriu nas Vidas Paralelas, de Plutarco, que a frase "Navegar é preciso; viver não é preciso" foi dita por Pompeu quando, a despeito de uma grande tempestade, mandou que suas naus partissem para Roma, com o trigo que tinham carregado na Sicilia, na Sardenha e na África. Cf. ZENITH, "Notas", in: PESSOA, Livro do Desassossego, p.519.
} 
abandono ao ato criativo. Pessoa claramente se entende como mediação para o poema, seu destino é criar, ainda que para isso tenha que fazer de seu "corpo [...] a lenha desse fogo", uma via de acesso a algo que é transformador e grandioso. Há claramente a compreensão de um perder-se para encontrar-se, de um ser nada para poder ser tudo, posto que essa morte significa uma existência autêntica e apropriada de si mesmo. Nesse sentido, essa morte é também vida, criação! Essa morte é também corpo se fazendo vida no fazer poético. Paul Klee, em um texto intitulado "Confissão criadora", nos fala algo sobre a gênese da obra de arte que ressoa profundamente com que acabamos de expor. Ele diz:

Um certo fogo que surge, que acende, que avança, que avança através das mãos para atingir a tela, que incendeia a tela, que salta em faíscas, fechando o círculo para retornar para seu lugar de origem: alcançando os olhos e continuando o seu avanço [de volta ao centro do movimento, da vontade, da ideia]. ${ }^{360}$

Ambos, Pessoa e Klee, valem-se do corpo inserido no fazer poético e artístico para falar do instante criativo, valem-se do fogo para falar do acontecimento que faz irromper o poema e a obra de arte; lugar em que ambos são tão somente passagem para o poético e o artístico em sua forma mais elevada. Neles, o corpo está totalmente inserido e integrado ao ser si-mesmo de cada um, está perfeitamente incorporado a um fazer que também os faz à medida que é feito. Nisso não há consciência ou subjetividade, "porque", continua Klee, "na esfera mais elevada da arte existe um segredo derradeiro, escondido por trás da diversidade de sentido, e a luz do intelecto lamentavelmente se apaga." ${ }^{361}$ Há aqui algo que se faz desde um imperativo vital: o homem desaparece, há apenas a entrega, o abandono à dimensão da transcendência, há apenas a espera e a escuta a desdobrar-se em abertura, de modo a dar vazão ao outro que o acomete a convocá-lo à consagração do instante. Trata-se de estar aberto a ser tocado, afetado, em sentido próprio. Trata-se de estar lançado, assentado, absolutamente sem porquê ou para quê - em pura gratuidade. Trata-se de um modo de ser que é destino, é envio, é irrupção, é liberdade. É isto que marca o poetar de Pessoa: ser livre para a possibilidade de ser aquilo que já sempre se é. Tal assunção nos é dada, como vimos, pela compreensão antecipada da finitude e da angústia que acabam por manifestar o ente em sua totalidade de

\footnotetext{
${ }^{360}$ KLEE, “Confissão criadora", in: 361 Ibidem, p.50. , Sobre a Arte Moderna e outros Ensaios, p.47.
} 
forma a trazer à luz o outro que se encontrava velado: o próprio ser-poeta Pessoa Cais e Destino de uma mesma viagem. 
“É preciso continuar, não posso continuar, vou continuar”, são as últimas palavras de Samuel Beckett, no livro O Inominável. Continuar é sua sina. É preciso dizer palavras. Ele não pode não dizê-las. Esta é a sua saga - lugar em que o poeta se encontra no envio de um destinar. Destino este que não se caracteriza por uma dimensão ôntica, relativa ao desenrolar dos acontecimentos que se dão no tempo, os quais, como diz Walter Benjamin, “oferece(m) a massa dos fatos acumulados para preencher o tempo vazio e homogêneo" 362 culminando numa história universal, mas um destino que, em nosso caso, se caracteriza por uma dinâmica existencial própria trazida pela angústia originária, cuja temporalidade se dá a partir de uma relação do poeta com o ser e com o mundo. Há nesta dinâmica uma antecipação da finitude da temporalidade que se põe como um fundamento velado da história. ${ }^{363}$ Quando isto irrompe, a poesia torna-se um caminho de prenúncio do acontecimento do ser, e o poeta, lançado neste envio, repousa no porvir da palavra anunciadora. É assim também com os filósofos. É a filosofia e a poesia - apesar de essências

\footnotetext{
362 BECKETT, O Inominável, p.127. Tradução de Waltersir Dutra: “[...] é preciso continuar, não posso continuar, é preciso continuar, vou então continuar, é preciso dizer palavras, enquanto houver, é preciso dizê-las, até que me encontrem, até que me digam, estranho castigo, estranha falta, é preciso continuar, isso talvez já tenha sido feito, talvez já me tenham dito isso, talvez me tenham levado até o umbral da minha história, ante a porta que se abre para a minha história, isso me espantaria, se ela se abre, serei eu, será o silêncio, aí onde estou, não sei, não o saberei nunca, no silêncio não se sabe, é preciso continuar, não posso continuar, vou continuar."

${ }^{362}$ BENJAMIN, O Anjo da História, p.19.

${ }^{363}$ Cf. HEIDEGGER, Ser e Tempo, p.478.
} 
singulares e distintas - que se acercam desse domínio. É o pensar e o poetar que buscam a verdade do mundo, e é somente nestes domínios que nos encontramos circunscritos à singularidade da palavra, pois aí segue-se uma transposição do ser do filósofo ou do poeta para o horizonte de uma verdade. Nos referimos aqui ao horizonte de uma linguagem originária, lugar em que ambos habitam na medida em que buscam ouvir as palavras nelas mesmas, de tal forma, que esta recepção os coloca em sintonia com aquilo que a palavra diz. É somente quando somos tomados por essa transposição que nos encontramos no âmbito mais próprio à palavra, no reino original que lhe é próprio. A saga poética não nos remete, assim como em tantos vocábulos de nossa língua cravejados por sedimentos que petrificam a fala, a algo da ordem de uma lenda inacreditável. Não! Referimo-nos à saga do próprio dizer, ao próprio mostrar da palavra, ao deixar aparecer da linguagem em seu todo.

São os filósofos e os poetas que nos contam do retorno à casa - esse lugar de reencontro e proximidade com a origem, de desdobramento do essencial, cuja morada é a proximidade do ser. Na célebre frase "a linguagem é a casa do Ser. Em sua habitação mora o homem" 364 , proferida na carta Sobre o Humanismo, Heidegger nos alerta que são os pensadores e os poetas os guardiões dessa morada, uma vez que consumam a manifestação do ser ao trazê-la e mantê-la na linguagem. Lembremos que o termo alemão para habitação é Behausung. Casa é das Haus, do substantivo formou-se o verbo hausen, que expressa a atribuição da casa: dar abrigo, morada, habitação. ${ }^{365}$ É neste movimento que mora o homem. Entretanto, sabemos que o homem se encontra na diáspora, não habita na sua linguagem, está fora de casa, vive no falatório, no blá-blá-blá do mundo das opiniões, da simples comunicação como meio de expressão. Há uma relação primordial com a linguagem que se perdeu no meio disso! O habitar a que o pensador alemão se refere diz respeito à própria abertura do homem, ao traço fundamental da presença humana. Quando Heidegger se refere às palavras de Hölderlin: “[...] poeticamente o homem habita [...]", ele não está se referindo à poesia como um adorno ou floreio capaz de enlevar o espírito. Poética é criação, é palavra criadora - e nada tem a ver com fazer rima -, tem a ver com o mais puro exercício de lucidez, com ser o mais próprio: a possibilidade de ser no sentido de ser. Para Heidegger, é preciso "libertar

\footnotetext{
${ }^{364}$ HEIDEGGER, Sobre o Humanismo, p.24. Maiúscula do tradutor.

${ }^{365} \mathrm{Cf}$. CARNEIRO LEÃO, nota do tradutor, in: Ibidem, loc. cit.
} 
a linguagem da gramática para um contexto Essencial mais originário.”366 É preciso liberar a gramatica da lógica. É preciso transpor a linguagem para fundamentos mais originários ${ }^{367}$, e esta tarefa está reservada ao pensar e ao poetizar. São os pensadores e os poetas que fazem do dizer um mostrar, fazem do dizer um ver e aparecer, fazem do dizer um dizer próprio, de tal forma sintonizado com a experiência de ser, que a linguagem se faz a casa do ser. A linguagem do pensador e do poeta será sempre a celebração disso! Cabe, pois, ao pensar e ao poetizar uma abertura mais originária para a linguagem que, traduzida inadequadamente pelo ocidente na forma da Lógica cristalizou-se como uma via de mão única. O lógico exprime uma coerência com os seus pressupostos que nada tem a ver com o verdadeiro. O lógico pode fundamentar a norma, mas nunca constituir o domínio do verdadeiro. ${ }^{368}$ Por ora, caberia a pergunta: o que constitui o domínio do verdadeiro? O que é verdade? De modo a trazer a questão da verdade para o nosso escopo, podemos adiantar que a poesia se torna um caminho de prenúncio do acontecimento de verdade. Porém, antes de nos lançarmos no tema da verdade e sua relação com a poesia, voltemos um passo atrás de modo a encaminhar o pensamento de modo apropriado para a questão.

Em nosso segundo capítulo, nos detivemos sobre a téchnē que, ligada à épistème, era compreendida como uma atividade elevada, significava um conhecimento, um saber. O fundamento desse conhecer presente na experiência grega estava totalmente voltado para o tornar manifesto, assim como a própria ideia do fazer e produzir em nada se aproximava de uma fabricação ou manipulação. Ambos simplesmente se direcionavam ao trazer à luz, ao deixar-aparecer. A téchnē nunca visava a manufatura em si, mas, sim, o saber fazer, ou melhor, o saber que tinha um domínio sobre o fazer. Por certo, estava incluído neste saber, regras e modos de procedimento. Entretanto, o conhecimento do método jamais se mostrava como essencial. ${ }^{369}$ Heidegger diz que, originariamente para os gregos, téchnē significava somente "um deixar-aparecer algo como isso ou aquilo, dessa ou daquela maneira, no âmbito do que já está em vigor." ${ }^{370}$ Isto significa que a téchnē trazia à luz algo que já vigorava desde e a partir de si mesmo. Um outro modo

\footnotetext{
${ }^{366}$ HEIDEGGER, Sobre o Humanismo, p.25-26. Maiúscula do tradutor.

${ }^{367}$ Cf. HEIDEGGER, Ser e Tempo, p.229.

${ }^{368}$ Cf. HEIDEGGER, Heráclito, 1998, p.126.

${ }^{369}$ Cf. HEIDEGGER, Nietzsche I, p.75, 149.

${ }^{370}$ HEIDEGGER, "Construir, habitar, pensar", in: , Ensaios e Conferências, p.139.
} 
possível da realidade se mostrar, do real se fazer vigente, chamava-se poíêsis. Poiésis é um termo que sempre esteve relacionado àquilo que passa da não vigência para a vigência, como uma produção. Todavia, esta produção deve ser entendida em um sentido mais amplo e não apenas como uma confecção artesanal. A poíessis era mais do que isto! Poíesis era o deixar aparecer daquilo que se mostrava, aquilo que permitia o ser das coisas desabrocharem por si mesmos. O que surgia e elevavase por si mesmo também era poíésis, pois, o que vige possui em si aquilo que irrompe. Há, pois, uma diferença entre algo que é produzido por alguém e algo que aparece por si mesmo, entre algo manipulado e algo que irrompe em seu ser. A partir desta visão mais ampliada, a palavra poíesis nos encaminha para uma outra palavra grega de extrema importância: alétheia. Por que dizemos isso? Sabemos que o termo alétheia foi durante muito tempo entendido como verdade. Como, então, podemos inferir que poiésis é um modo de ser e de fazer-se alétheia? Por certo, não estamos nos referimos à tradição grega na qual alêthés era usada para expressar certeza e confiança, nem tampouco no sentido medieval quando passou a ser entendida como veritas. A alétheia não pode ser identificada à palavra verdade, pois, neste escopo, compreende-se a verdade como concordância e adequação - o acordo da representação pensante e da coisa - sempre relacionadas ao conhecimento do ente. Como vimos anteriormente, a verdade experimentada como retitude da representação e da enunciação se põe à luz do ente e fica reduzida ao sentido de orthótēs. Heidegger quer escapar deste campo gravitacional. O que o pensador alemão tem em mente para o vocábulo alétheia é o sentido de desvelamento, desocultação, abertura, algo muito bem compreendido pelos pensadores da origem, especialmente Parmênides, que se referiu à alétheia como o "lugar do silêncio que concentra em si aquilo que primeiramente possibilita desvelamento." ${ }^{371}$ A alétheia pensada como desvelamento, como clareira da presença, não é a verdade. A clareira é eminentemente o silenciar que recolhe em si a possibilidade do desvelar. Todavia, a verdade só pode se dar no aberto da clareira, no desvelamento. A imagem da clareira no meio de uma floresta densa nos oferece uma visão bastante propícia para pensarmos a questão originária: um espaço onde a livre dimensão do aberto, uma vez contemplada, venha a falar algo a nossa alma, tanto do que se faz presente como do que se faz ausente. Há na clareira

${ }^{371}$ HEIDEGGER, "O fim da filosofia e a tarefa do pensamento", in: ,Os Pensadores, p.104105. 
uma ocultação que se mantém. Uma analogia para esta mesma questão é feita por Ortega y Gasset, em um ensaio intitulado "Meditaciones del Quijote", quando se refere a uma lenda alemã que diz que as árvores de uma floresta não deixam ver a floresta. Vemos, sim, com clareza e minúcia de detalhes, toda a flora que compõe a floresta, mas a floresta mesmo nós não vemos. Esta foge dos olhos e se oculta. $\mathrm{Na}$ realidade, a floresta está sempre para além de onde estamos e incessantemente se põe como uma possibilidade. Aquilo que se põe diante de nós, de maneira imediata, é apenas um pretexto para aquilo que se oculta, para aquilo que, apesar de latente, está sempre invisível. A floresta existe e guarda em si o seu mistério. Entretanto, é exatamente quando nos damos conta que aquilo que vemos oculta algo que não vemos é que nos sentimos dentro da floresta. Esta invisibilidade não é negativa, mas, ao contrário, nos abre sempre a possibilidade para o inesperado, para algo aparecer. Segundo o pensador espanhol, as coisas quando manifestas perdem, por vezes, o seu valor e quando ocultas guardam sua plenitude. Mesmo a superfície guarda em si uma profundeza que não se mostra. ${ }^{372}$ Álvaro de Campos nos ajuda a pensar a questão da superfície ofertada pelo pensamento do pensador espanhol. Ouçamos seu canto:

Ver as coisas até ao fundo...

E se as coisas não tiverem fundo?

Ah, que bela a superfície!

Talvez a superfície seja a essência

E o mais que a superfície seja o mais que tudo

E o mais que tudo não é nada.

Ó face do mundo, só tu, de todas as faces, És a própria alma que reflectes. ${ }^{373}$

O que queremos expressar através dos versos de Campos é que existe uma parte da realidade que se abre aos nossos olhos e ouvidos sem nenhum esforço. O difícil é ver a superfície. Talvez a superfície seja a essência, diz o poeta, o mais que tudo; um tudo que não é nada, mas é a face que reflete a essência, a própria alma do mundo. Isto significa que além daquilo que vemos existe ainda um mundo constituído por impressões que, mesmo latente em relação ao outro, não deixa de ser real, apenas exige mais de nós. Há no passivo uma visão ativa que nos leva para

\footnotetext{
372 Cf. ORTEGA Y GASSET, "Meditaciones del Quijote", in: p.309-337.

${ }^{373}$ PESSOA, Álvaro de Campos - Livro de Versos, p.60. , Obras Completas, tomo I,
} 
além do simples olhar. Em ambas as analogias, de Heidegger e Ortega y Gasset, nos encontramos diante da clareira que ao mesmo tempo que abre, fecha. Lembremos do alfa privativo que compõe a palavra a-létheia que ao se relacionar com a -léthe - que significa ocultação, velamento, esquecimento - nos envia para a des-ocultação, o des-velamento, o des-esquecimento.

À guisa de buscar uma compreensão para a relação da lêthē com a alétheia, lembremos da bem arquitetada narrativa do Livro X, de Platão, sobre o desesquecimento. Platão narra o mito de Er que ao ser enviado ao Hades, o rio dos mortos, é ordenado ouvir e observar tudo o que havia naquele lugar, de modo a que servisse como uma espécie de porta-voz a relatar para os homens aquilo que vira e ouvira. Impedido de beber das águas do $L e ̂ ́ t h e \bar{e}$, Er não poluiu sua alma com o esquecimento. Ele é o mensageiro, aquele que se põe em uma posição medial, entre os dois mundos: o mundo do esquecimento e o do des-esquecimento. ${ }^{374}$ Mas o que isto tem a ver com o que falávamos? O que nos interessa no mito é exatamente a relação de entremeio que se estabelece entre o esquecimento e o des-equecimento, entre a lêthē e a alétheia. Tal relação está presente nas anotações de uma conferência de Heidegger sobre a "Segunda Consideração Intempestiva" de Nietzsche, onde o pensador, no parágrafo 15, diz que no grego a palavra "esquecimento" é medial, se situa entre o activum e o passivum, ou seja, não é ativa e nem passiva. O que é esquecido contém em si mesmo a relação com o agente sem, contudo, estar completamente sujeito ao poder deste último, pois, mesmo não presentificado o esquecido jaz no retraimento. Isto significa que o esquecimento é mais do que um mero ato de não lembrar. O esquecimento ocorre no retraimento. Isto é constitutivo. ${ }^{375}$ Ser se dá sempre como abertura, mas este dar-se conta de ser na compreensão de ser não está dado, sobre isso não há consciência, não há intelectualismo, nem formalismo, o "lugar aberto no seio do ente, a clareira, nunca é um palco rígido, com o pano sempre levantado e sobre o qual o jogo do ente se representa. [...] A desocultação do ente nunca é um estado que está aí, mas um acontecimento" 376 - o acontecimento. Aquilo que nos diz Lacoue-Labarthe: "[...] o puro e simples desvelamento, a simples saída da noite e o puro brilho do sol." ${ }^{377}$ Há,

\footnotetext{
${ }^{374}$ Cf. PLATÃO, A República, p.484-497.

${ }^{375}$ Cf. HEIDEGGER, Interpretation of Nietzsche's Second Untimely Meditation, p.47-60.

${ }^{376}$ HEIDEGGER, A Origem da Obra de Arte, 1977, p.43.

${ }^{377}$ LACOUE-LABARTHE, "A verdade sublime", in: A Imitação dos Modernos, p.248.
} 
todavia, neste puro e simples desvelamento um velamento, há nesta relação uma copertença entre desocultação e ocultação, entre o já e o ainda não, que é própria da relação. O essencial é compreendermos que, mesmo retido no esquecimento, é a relação com o que é esquecido que mantém o ser como tal em aberto. ${ }^{378}$ A alétheia, portanto, possui uma cifra de desvelamento, mas, também, de retenção e velamento. Há nisto um retraimento que deve ser celebrado como retraimento enquanto tal. $\mathrm{Na}$ clareira, tudo se evidencia, tudo se torna claro, mas também se fecha e se preserva em sua originariedade, "semelhante a uma fonte que só jorra enquanto se preserva a si mesma." ${ }^{379}$

Assim, na medida em que a alétheia se põe como a possibilidade do desvelamento e a poíesis como aquilo que irrompe do velado para o desvelado, alétheia e poíesis estão de algum modo relacionadas. Para Heidegger, assim como o pensar do ser busca por algo impensado, a poesia também faz do impensado o seu caminho. Isto não significa que a poesia pensada por Heidegger seja aquela do gênero literário. É preciso que se diga que a poesia é aqui pensada como obra da linguagem, "o ponto de articulação do ser que chega à palavra" ${ }^{380}$ através de sua interseção com o pensamento. Referimo-nos ao próprio dizer do ser que, através de uma escuta silenciosa, se manifesta no dito poético. É, pois, neste sentido, que o pensador alemão compreende que o ser espera pelo homem pensante capaz de trazer à linguagem algo que permanece velado. Este é o lugar do poeta. É o poeta que se acerca das palavras de modo a torná-las próprias com aquilo que é. Ele é aquele que se aproxima do vazio - lugar onde habita o sentido das coisas. Na conferência "A essência da linguagem”, proferida entre 1957, Heidegger diz que

[...] para o poeta, a palavra se diz como aquilo a que uma coisa se atém e contém em seu ser. O poeta faz a experiência de um poder, de uma dignidade da palavra, que não consegue ser pensada de maneira mais vasta e elevada. A palavra é, ao mesmo tempo, aquele bem a que o poeta se confia e entrega, como poeta, de modo extraordinário. ${ }^{381}$

Na lida do poeta com a palavra, uma particularidade acontece: o poeta é tomado por algo que irrompe de uma ausência para uma presença e restaura a experiência de mistério na fala e no discurso. Poíessis é isso! É o átimo entre o não-ser e o ser,

\footnotetext{
${ }^{378}$ Cf. HEIDEGGER, Interpretation of Nietzsche's Second Untimely Meditation, p.53.

379 HEIDEGGER, Parmênides, p.32.

380 HÜHNE, "O Poetar pensante", in: BERARDINELLI et alii, Fernando Pessoa e Martin Heidegger: O Poetar Pensante, p.72.

${ }^{381}$ HEIDEGGER, "A essência da linguagem", in: , A Caminho da Linguagem, p.129.
} 
é o instante que se abre como possibilidade entre o nada e o tudo. Dito nas palavras de Platão, no diálogo entre Sócrates e Diotima, em O Banquete: “[...] toda a causa de qualquer coisa passar do não-ser ao ser é 'poesia', de modo que as confecções de todas as artes são 'poesias', e de todos os seus artesãos poetas." ${ }_{382}$ Entendemos, com isso, que o poético é a força geradora capaz de levar o real a emergir, ao desencobrimento, ao esplendor superlativo. Nisto há o extremo de um poder-ser, o extremo de um vigor que se mostra, o mais puro princípio de realidade. Lembremos que no grego, poíesis é a ação de poieîn, infinitivo neutro do verbo poiéō, que significa fazer, produzir, criar, poetar. Poiésis é a palavra que mostra, que torna visível alguma coisa. Este era o modo como os gregos entendiam a poíesis: a ação e atividade de fazer aparecer, um modo de ser da phýsis de se mostrar e se realizar. Pura eclosão em si mesma! O poeta era partícipe da phýsis ao falar da phýsis. Neste caso, a ação criadora é uma ação que não é um automatismo, é uma ação que recai sobre quem faz e transforma quem faz: não é o poeta que faz poesia, é a poesia que o faz. Na poiésis, o fazer não é o fazer do homem, mas é um deixar vir a ser da abertura da dimensão da transcendência. A própria saga poética, a saga do dizer como um mostrar, não pode ser considerada exclusivamente como um feito do homem, pois, "mesmo quando o mostrar se dá através de nosso dizer, esse mostrar [...] está sempre precedido de um deixar-se mostrar." ${ }^{383}$ Há algo que vem primeiro. Isto é algo muito bem compreendido na aurora grega. Na Grécia antiga, não era o homem que contemplava o mundo, ao contrário, era o kósmos que espontaneamente se apresentava e sobrevinha ao homem, o qual se abria à experiência da presença daquilo que nele se presenciava. A phýsis era, pois, o resultado do conteúdo dessa experiência. Com isso, a medida da coisa era dada pela própria coisa.

Mas o que é coisa? Por certo, não nos referimos a uma compreensão abstrata, conceitual, teórica. O que é uma pedra, uma rosa ou um sapo pode ser respondido pela mineralogia, botânica ou zoologia, respectivamente. A ciência busca respostas para tudo o que existe, apenas não podemos esquecer que isto é apenas aquilo que uma determinada coisa é para A, B ou C. Já nos diria Caeiro, em 1918:

Todas as opiniões que há sobre a Natureza

Nunca fizeram crescer uma erva ou nascer uma flor.

\footnotetext{
382 PLATÃO, O Banquete, p. 127. Neste escrito, o termo grego poíêsis foi traduzido por poesia.

${ }^{383}$ HEIDEGGER, A Caminho da Linguagem, p. 203.
} 
Toda a sabedoria a respeito das coisas

Nunca foi coisa em que pudesse pegar, como nas coisas.

Se a ciência quer ser verdadeira,

Que ciência mais verdadeira que a das coisas sem ciência?

Fecho os olhos e a terra dura sobre que me deito

Tem uma realidade tão real que até as minhas costas a sentem.

Não preciso de raciocínio onde tenho espáduas. ${ }^{384}$

Quando Caeiro fala das coisas não está interessado no entendimento científico sobre elas. Esta é sempre uma compreensão tardia. Não há que se ter sabedoria, raciocínio ou opinião. Pessoa também teria dito: “O que constitui a essência de uma coisa é aquilo que, retirado a essa coisa, a mesma coisa desaparece" 385 , ou seja, a coisa é só o que é e nada mais. Cada coisa é única. Quando perguntamos "o que é coisa?" buscamos na realidade saber o que faz a coisa ser coisa enquanto coisa, o caráter de coisa da coisa. Há nisto uma singularidade, e sobre a singularidade das coisas as ciências não se detêm, isto é posto de lado. Não nos damos conta, ou sequer questionamos, que somos jogados dentro de um universo de significados e o que uma cadeira é para o dentista, não é o mesmo que para um condenado à morte ou para um deficiente. Para cada um, a cadeira tem o seu modo próprio de ser cadeira. Há uma distinção entre elas que faz cada uma ser o que é. Por isso, podemos dizer que a cadeira é sempre a mesma - um objeto com quatro pernas (ou rodas!) usado para sentar - mas não é igual. Cada cadeira é uma cadeira e nenhuma outra. Isto nos fala exatamente de uma unidade na pluralidade, do um que é múltiplo, do mesmo que não é igual, pensado na origem grega por Heráclito quando se refere ao divergente que consigo mesmo concorda, ao um que diferenciado de si mesmo unese a si mesmo em uma harmonia dos contrários, presente na infindável dinâmica de realização do real. ${ }^{386}$ Caeiro tem uma compreensão bem clara sobre isto quando diz, em 1915:

Tenho escrito bastantes poemas.

Hei de escrever muitos mais, naturalmente.

Cada poema meu diz isto,

E todos os meus poemas são diferentes,

Porque cada cousa que há é uma maneira de dizer isto. ${ }^{387}$

\footnotetext{
${ }^{384}$ PESSOA, Obra Poética, p.242-243; idem, Obra Completa de Alberto Caeiro, p.103.

385 PESSOA, Ultimatum e Páginas de Sociologia Política, p.31.

${ }^{386}$ Cf. HERÁCLITO, frag.50-51, Os Pensadores Originários: Anaximandro, Parmênides, Heráclito, p.71.

${ }^{387}$ PESSOA, op. cit., p.234-235; idem, op. cit., p.91.
} 
A partir dos versos podemos elencar que: cada poema é diferente do outro, mas são todos poemas; cada poema diz o mesmo, mas não são iguais; cada poema é um poema a partir de sua relação com todos os outros poemas, pois, na dinâmica e no vigor de realização, nada é isoladamente o que é, sempre se está em relação com todas as outras coisas. Ainda assim, cada poema é único porque é o próprio poema que dita a maneira de dizer. Há neste dizer um aparecer que irrompe em uma presença $^{388}$, e, por assim ser, é o próprio poema que aparece. Subsumido a isto, está a questão espaço-tempo, pois é exatamente o lugar e o tempo em que o poema aparece que determina a sua singularidade e faz com que ele seja este e não aquele poema. ${ }^{389}$ A referência espaço-temporal implica em uma relação direta do poema com o seu lugar e o seu tempo, de tal modo que o poema se torna único e inconfundível. Tudo isso parece se basear em algo externo, mas seguramente não se trata da relação sujeito-objeto pensada por Descartes. Isto que aparece e está diante de nós não é algo objetivo e nem tampouco subjetivo, independe do nosso querer ou vontade que algo se presentifique, mas, da sincronicidade com que a singularidade de cada coisa coincide com o espaço e o tempo em que a própria coisa se encontra. É o aqui e o agora que a tornam única. Ainda que espaço e tempo determinem, por assim dizer, a coisa, espaço e tempo não pertencem ao domínio da própria coisa, apenas designam a possibilidade de indicação e encontro com a coisa. Para entendermos como e quando a coisa aparece como coisa, é preciso um passo atrás. É preciso abandonar o pensamento representativo, que se processa na autoconsciência do eu humano, para o pensamento meditativo, que pensa o sentido. ${ }^{390}$ Trata-se mesmo de um fenômeno experimentado na percepção sensível, a qual, como dissemos no capítulo anterior, se refere a uma passividade receptiva relacionada a um modo todo próprio de ser do homem. De modo bastante precipitado, podemos afirmar que o que faz uma coisa ser coisa é a sua verdade. Não a verdade supratemporal e eterna como outrora se pensava! Muito menos a verdade entendida como correspondência e adequação a alguma realidade externa, objetiva ou subjetiva. Mas a verdade que acabamos de ver, o desencobrimento, a alétheia, aquela que mesmo apartada de todas as aproximações ônticas, está

\footnotetext{
${ }^{388}$ Cf. HEIDEGGER, Que é uma coisa?, p.39.

${ }^{389}$ Cf. Ibidem, p.30.

${ }^{390}$ Cf. HEIDEGGER, “A coisa”, in: Ensaios e Conferências, p.159.
} 
totalmente imbricada com o modo de ser do homem. A pergunta pela coisa está, pois, de algum modo, atrelada à pergunta pelo homem. Diz Heidegger:

A questão "Que é uma coisa?" é a questão "Que é o homem?". Isto não significa que as coisas se reduzam a um resultado da atividade humana, mas, pelo contrário, quer dizer que o homem deve conceber-se como aquele que, desde sempre, ultrapassa as coisas, mas de tal modo que este ultrapassar somente é possível na medida em que as coisas vem ao encontro e, deste modo, permanecem justamente elas próprias, na medida em que nos remetem para aquém de nós mesmos e da nossa superfície. ${ }^{391}$

Heidegger se refere aqui à questão kantiana acerca da coisa. Para ele, Kant, ao formular o princípio supremo de todos os juízos sintéticos, abre um horizonte que se encontra entre a coisa e o homem e cujo âmbito se amplia para além de ambos. Trata-se de algo que só pode ser concebido na forma de uma captação prévia, a qual acontece $s e-$ e somente $s e-o$ homem já está no entre do homem e da coisa. É o estar entre que captura para além da coisa e, no mesmo ato, para antes do homem, como algo que se dá primeiro. Como em uma retrojeção que, diferentemente da projeção que lança algo sobre algo, esta capta e recebe algo de outrem. Entendemos que este retrojetar orbita no mesmo escopo da palavra Vernehmen, por nós examinada no capítulo anterior, e que se refere à capacidade intangível de receberperceber aquilo que chega até nós, como uma apreensão-percepção-sensível, a qual também agrega a ideia de escuta. Esta compreensão à respeito de Kant nos é ofertada ao final das preleções do curso do semestre de inverno de 1935/36, publicadas no livro Que é a coisa?, quando diz em seu último parágrafo: "Por isso, quando lemos nessa atitude - a começar pela primeira frase da Crítica da Razão Pura - tudo se move, desde o começo, a uma luz diferente." ${ }^{392}$ Isto significa que Heidegger vislumbrou algo neste entre kantiano capaz de lançar novas luzes sobre a relação do homem com a coisa. O problema que se põe, não só nesta última parte da obra de Kant mas em toda a obra, é que via de regra nos colocamos de modo impróprio à analise, nosso modo de pensar está sempre atrelado a uma visão que ora está voltada para aquilo que é dito sobre o objeto ora para a discussão acerca do modo de o experimentar. $\mathrm{O}$ decisivo nisto não é nem uma coisa nem outra. $\mathrm{O}$ que conta é o posicionamento entre as coisas e o homem. Este estar entre quer dizer, em outros termos, o acontecimento de uma experiência que, ao mesmo tempo em

\footnotetext{
${ }^{391}$ HEIDEGGER, Que é uma coisa?, p.305.

${ }^{392}$ Ibidem, p.304.
} 
que dá origem a um círculo, se abre àquilo que se encontra no interior do círculo. Referimo-nos a ideia de salto que nos coloca entre nós e a coisa. Para Heidegger, quando Kant diz que o princípio do entendimento puro torna possível, a partir da experiência e sempre pressuposto por ela, o próprio fundamento de sua demonstração, isto significa que, no fundo, é a experiência da coisa que faz a coisa ser coisa. ${ }^{393}$ Todavia, como vimos no capítulo anterior, sabemos que esta experiência não se faz a partir da vontade do homem, este é atravessado pela experiência de tal modo que dela se torna vassalo. Caminhemos um pouco mais tendo em mente as perguntas: o que é coisa? Como pode a pergunta pela coisa ser a pergunta pelo homem?

Tentemos esboçar alguma resposta com uma pequena estória contada por Álvaro de Campos que, referindo-se à sensibilidade de Caeiro na relação direta com as coisas, cita o seguinte poema de Wordsworth:

A primrose by the river's brim A yellow primrose was to him. And it was nothing more.

Na tradução do próprio Campos, que omitiu o nome da flor por desconhecer o nome de flores e plantas, o poema diz:

Uma flor à margem do rio

Para ele era uma flor amarela.

E não era mais nada. ${ }^{394}$

Campos conta que Caeiro ri e diz: "Esse via bem. Uma flor amarela não é realmente senão uma flor amarela". Mas, após algum tempo, acrescenta:

Há uma diferença. Depende se se considera a flor amarela como uma das várias flores amarelas, ou como aquela flor amarela só. O que o seu poeta inglês queria dizer é que para o tal homem essa flor amarela era uma experiência vulgar, ou coisa conhecida. Ora isso é que não está bem. Toda coisa que vemos, devemos vê-la sempre pela primeira vez, porque realmente é a primeira vez que a vemos. E então cada flor amarela é uma nova flor amarela, ainda que seja o que se chama a mesma de ontem. A gente não é já o mesmo nem a flor a mesma. O próprio amarelo não pode ser já o mesmo. É pena a gente não ter exatamente os olhos para já saber isso, porque então éramos todos felizes. ${ }^{395}$

\footnotetext{
${ }^{393}$ Não é nossa intenção discutirmos a Crítica da Razão Pura, de Kant. Nosso intuito é o de esboçar aqui a leitura de Heidegger sobre o princípio supremo de todos os juízos sintéticos ao final de suas preleções. Parece-nos que o próprio Heidegger entende que Kant se coloca de modo novo acerca da pergunta pela coisa, pois, ao perguntar pela coisa, Kant também pergunta pelo intuir, pelo pensar, pela experiência e seus princípios, em suma, diferentemente da tradição, Kant pergunta pelo homem. ${ }^{394}$ CAMPOS, “O conceito direto das coisas", in: PESSOA, Obras em Prosa, p.108.

${ }^{395}$ Ibidem, loc. cit.
} 
Para Caeiro, os versos de Wordsworth referem-se a uma pré-compreensão da flor ao anunciar que a flor amarela nada mais é do que uma flor amarela atesta que já se tem em mente o que uma flor amarela é. Há por trás disso, toda uma representação prearranjada, preconcebida, esquematizada da flor que se põe à margem do rio. Todavia, a visão de Caeiro, livre dessa influência dogmatizante, nos fala de uma flor amarela que se manifesta a cada vez diferentemente, vem à luz de acordo com uma dimensão própria: a mesma flor amarela pode ser aquela à beira da margem do rio, a flor amarela da vendedora de flores ou a flor amarela do quadro de Van Gogh. Todas são flores amarelas, mas cada uma pertence a uma dimensão distinta, cada uma abre um horizonte que manifesta, a cada vez, aquilo que a flor amarela é. A flor amarela não é em si uma flor amarela. Ela aparece diferentemente em infindáveis dimensões, em diferentes perspectivas de posicionamento. É a descoberta do olhar que faz aparecer a flor amarela, que deixa a flor amarela ser aquilo que ela é. Vista desta forma, ela não é sinal nem indicação para algo além dela. Ela é vista pela primeira vez e a cada vez sempre como ela mesma. Por esse ver, o poeta é feliz! Coisa é sempre um mundo, um sentido, um lógos, a partir do qual coisa aparece como tal. Ver a coisa nela mesma é deixar que ela apareça desde o mundo que ela é, é sempre ver a partir do seu interesse. Só que para isso, diz Heidegger, é preciso "ser sob, entre e no meio das coisas; estar numa coisa de permeio e junto dela assim persistir." ${ }^{396} \mathrm{Na}$ língua latina, o vocábulo interesse vem de inter-èsse: inter, dentro; èsse, essere, ser. ${ }^{397}$ Interesse significa ver sempre desde dentro do modo de ser que é o da própria coisa. Mas como é possível ver a coisa desde o seu modo próprio de ser? Como dissemos, não se trata nem de uma visada objetiva e, nem tampouco, subjetiva, mas, de uma abertura que se dá no homem a partir da qual a coisa vem a ser a coisa que é. Como dissemos, o que faz uma coisa ser o que ela é é o mundo em que ela está, o mundo em que ela aparece, mas para isso é preciso que o olhar esteja num outro registro, num outro horizonte - o da transcendência -, que, como vimos, diz respeito a uma dimensão, a uma possibilidade de vida e existência que sobrevém ao homem, e somente ao homem, pois ele é o único que pode ser tocado e tomado por transcendência. Esta possibilidade de existência encontra-se no porvir do homem, mas ele não tem poder sobre isso. Ele partilha e participa desta dimensão, mas isto que é a transcendência

\footnotetext{
${ }^{396}$ HEIDEGGER, “O que quer dizer pensar?”, in: ___ _ Ensaios e Conferências, p.113.

${ }^{397}$ ERNOUT; MEILLET, Dictionnaire Etymologique de la Langue Latine, p. 312.
} 
o ultrapassa. Ele é passagem, é aquele que deixa-ser. Não há nisto nem passividade nem atividade, mas, sintonia e sincronia com a própria coisa. A phýsis como este irromper, brotar e eclodir só se dá para um olhar interessado, para um tal olhar que é participe disso e que está na possibilidade do sentido do mostrar-se. "Quer isto dizer”, nos diz Pessoa, “[...] que as nossas sensações ou impressões das coisas externas, nenhum valor têm se não ajustarem a essas coisas, se as não abonar uma conformidade com a realidade. ${ }^{\prime 398}$ Completamente afinado e em total sintonia com esta questão, ouçamos os versos de Alberto Caeiro, do poema XXVIII, de "O guardador de rebanhos", escritos em 1914:

Li hoje quase duas páginas

Do livro dum poeta místico,

E ri como quem tem chorado muito.

Os poetas místicos são filósofos doentes,

E os filósofos são homens doidos.

Porque os poetas místicos dizem que as flores sentem

E dizem que as pedras têm alma

E que os rios têm êxtases ao luar.

Mas as flores, se sentissem, não eram flores,

Eram gente;

E se as pedras tivessem alma, eram coisas vivas, não eram pedras;

E se os rios tivessem êxtases ao luar,

Os rios seriam homens doentes.

É preciso não saber o que são flores e pedras e rios

Para falar dos sentimentos deles.

Falar da alma das pedras, das flores, dos rios,

É falar de si próprio e dos seus falsos pensamentos.

Graças a Deus que as pedras são só pedras,

E que os rios não são senão rios,

E que as flores são apenas flores.

Por mim, escrevo a prosa dos meus versos

E fico contente,

Porque sei que compreendo a Natureza por fora;

E não a compreendo por dentro

Porque a Natureza não tem dentro;

Senão não era a Natureza. ${ }^{399}$

Os versos contam de um poeta místico que fala do sentimento das flores, da alma das pedras e do êxtase dos rios. Trata-se de uma humanização da natureza, uma espécie de prescrição que determina aquilo que a natureza é. E não só isto! Esta prescrição é dada pelo homem. É ele quem diz e determina aquilo que a natureza

\footnotetext{
398 PESSOA, Ultimatum e Páginas de Sociologia Política, p.32.

399 PESSOA, Obra Poética, p. 219.
} 
sente. Contrário a isto, nos deparamos com a simples constatação do poeta, que conta de um saber que nada impõe às flores, às pedras ou aos rios, mas apenas os compreende em si mesmos. Isto significa que não há algo por trás da natureza, mas apenas o desencobrir da natureza como natureza, em si mesma e desde si mesma. Isto é o mesmo que ver a natureza. Há nisto um contentamento, uma satisfação. Quando se vê assim, há uma abertura - o ver abre um horizonte, uma perspectiva. Isto é desencobrimento. É alétheia. Este é o instante em que o real se faz, é o irromper da realização do real. Para conhecer é preciso estar em sintonia com esta abertura possibilitadora que instaura o aparecer. Se isso acontece, dá-se o conhecer que, no francês - connaître -, tanto quer dizer conhecer como co-nascer ou nascer com. ${ }^{400}$ Esta é uma participação existencial que traz à tona todo um modo de vida. Podemos dizer que, na origem grega, compreendia-se toda e qualquer realidade na medida em que se colocava em estado nascente com a própria coisa. Colocava-se em participação, harmonizava-se e afinava-se à coisa a partir dela mesma. Com isso, a coisa nascia, aflorava, desabrochava em todo o seu esplendor e graça, em pura gratuidade, como nos falam os versos do mestre:

A espantosa realidade das coisas

É a minha descoberta de todos os dias.

Cada coisa é o que é,

E é difícil explicar a alguém quanto isso me alegra,

E quanto isso me basta. ${ }^{401}$

Através das palavras de Caeiro, podemos inferir que na espantosa realidade das coisas há o sentido elevado de um deixar-ser, nisto integra-se a ideia que a natureza não era nada estranho e fora do homem, ela acontecia junto ao seu olhar. O homem não era o autor da natureza, era seu habitante, o destinatário, aquele que fazia morada em meio aos entes em sua totalidade. Há nisso uma completude, uma satisfação, uma alegria. As artes aí fulguravam como um desencobrimento de verdade. Avancemos, por fim, sobre a questão da verdade: o que queremos dizer quando falamos em desencobrimento de verdade?

Quando falamos em verdade, devemos pensar qual a compreensão estava presente na origem grega. Trata-se de pensarmos a verdade como o desencobrimento do que se encobre, em total conformidade com a coisa. O

\footnotetext{
${ }^{400}$ ROBERT, Dictionnaire du Français Primordial, p. 212.

${ }^{401}$ PESSOA, Obra Poética, p.234; idem, Obra Completa de Alberto Caeiro, p.91.
} 
problema é o modo como se fixou, ao longo da tradição metafísica, esta compreensão. Referimo-nos a um pressuposto dado que não é questionado. Não se trata de negar toda a compreensão de correspondência ou adequação, o que Heidegger pretende é questionar o conceito de verdade a partir desses pressupostos, uma vez que isto que é o enunciado e a coisa não são o mesmo, mas, apenas uma relação do enunciado com a coisa. Antes, porém, voltemos nosso olhar de modo breve para a questão do enunciado. Estamos, aqui, inseridos no reino da palavra. Uma palavra isoladamente não diz nada sobre a verdade, mas uma palavra ligada à outra forma um enunciado que pode ou não ser verdadeiro. O que é, então, um enunciado? São vários os significados para este vocábulo. Distinguem-se quatro significados que se amalgamam entre si de modo a construir a unidade do enunciado: uma proposição, uma informação, uma comunicação, e, por fim, uma expressão. $\mathrm{O}$ enunciado se dá, então, quando comunicamos $a$ alguém uma proposição acerca de uma coisa e fornecemos alguma informação sobre ela. Isto significa que

o enunciado tem um caráter triplo: uma proposição, que dá uma informação, a qual realizada expressamente diante de outra pessoa, se torna comunicação. A comunicação é exata quando a informação é correta, quer dizer, quando a proposição é verdadeira. ${ }^{402}$

A partir disso, podemos inferir que o enunciado, ao percorrer o caminho da proposição, torna-se o lugar da verdade na medida em que os elementos dessa construção estão em conformidade com a coisa. Sabemos, entretanto, que a conformidade e adequação com a coisa não é a coisa, uma vez que não falam $a$ partir dela, mas acerca de e sobre ela. Além de trazer consequências graves para a coisa, a linguagem e a verdade também se encontram enredadas na complexidade desta trama, pois, quando se diz que a verdade está no enunciado da proposição, toma-se isto como uma estrutura primária, elementar da linguagem, quando na realidade o enunciado necessita de uma compreensão prévia da coisa para poder formular algo sobre ela. Heidegger se reporta a esta questão em dois momentos distintos: o primeiro, em 1927, no $§ 33$ de Ser e Tempo, quando nos faz entender que não é correto dizer que a verdade está no enunciado da proposição, uma vez que o enunciado é tardio, “[...] não paira no ar, desligado e solto, a ponto de poder

\footnotetext{
${ }^{402}$ HEIDEGGER, Que é uma coisa?, p.53.
} 
por si mesmo abrir pela primeira vez o ente como tal [...].403 O segundo, em 1930, na conferência "Sobre a essência da verdade", quando afirma que "a verdade originária não tem sua morada original na proposição." ${ }^{{ }^{404} \mathrm{O}}$ que Heidegger quer dizer com ambas as afirmações é que o enunciado da proposição é apenas uma representação da coisa, ou melhor, uma re-apresentação da coisa tal como ela aparece ao sujeito, algo que se dá como já constituído. Na realidade, é a coisa que se adequa ao entendimento, à razão humana. Isto é decisivo na medida em que qualquer coisa que apareça como coisa é um posicionamento dado pelo sujeito que enuncia, é um objeto re-apresentado pelo sujeito, é posição da subjetividade, da consciência do eu. Por isso, quando se fala de adequação e correspondência a coisa já está dada. Esta dinâmica de objetivação desconhece qualquer limite e se apodera inclusive da linguagem que vai se estratificando, adquirindo camadas que petrificam a palavra. A linguagem que está inserida nesta dinâmica não pode ser medida para uma linguagem originária, cocriadora de realidade. $\mathrm{O}$ enunciado só é possível a partir da sintonia com a coisa. Se isso não acontece, este é apenas uma representação da coisa que assume o lugar de verdade ${ }^{405}$, e a linguagem é apenas comunicação, instrumentalização, senso comum. Mas, então, o que é verdade?

Verdade é o movimento de mostração da coisa, é a aparição da coisa como coisa e não de correspondência com a coisa. Verdade é desocultação, desvelamento. Não se trata de uma dimensão objetiva da coisa, mas de um modo próprio de ser do homem, um modo de ser do olhar que acontecerá ou não na medida em que se está desperto, acordado, inserido em um modo de ser que é transcendência. Não há uma constatação ou asseguramento para este modo de ser, lembremos que há uma cifra de ausência na presença que é constitutiva, o que há é o salto para uma dimensão própria, na qual dá-se o acontecimento da verdade em uma dinâmica de participação no desvelamento que é o real - o átimo do aparecer da coisa, no qual ela permanece em sua instância. Quando isso se dá, se concretiza a relação. Como vimos no capítulo anterior, é a própria abertura que põe uma coisa para outra em um modo de copertencimento. É porque a relação já aconteceu que se dá a condição de possibilidade para o enunciado. Uma vez neste modo de ser, quando se vê alguma coisa, é a própria coisa que aparece e não uma representação da coisa. Quando se

${ }^{403}$ Cf. HEIDEGGER, Ser e Tempo, p. 218.

${ }^{404}$ HEIDEGGER, "Sobre a essência da verdade", in:

${ }^{405}$ Cf. HEIDEGGER, Ser e Tempo, p.215-223. , Os Pensadores, p.159. 
vê, já se vê dentro dessa perspectiva. O que faz a coisa ser coisa é algo que ultrapassa a própria coisa; o grego chamou isso de phýsis, o modo todo próprio de ser e aparecer, lugar em que o homem desperta para o sentido do sentido, para a visão do ver. O elemento próprio do homem é o ver - que é ser no sentido de aparecer; e porque o homem é aquele que diz, ele é aquele que pelo dizer presentifica aquilo que se faz presente. ${ }^{406}$. Verdade é, pois, o modo próprio de ser do homem. O homem é irrevogavelmente no sentido de verdade - o homem é desvelamento -, mas, como vimos, isso não está dado, ele precisa despertar para o que ele é. Isso é decisivo!

Voltemos nosso olhar agora para as palavras de Caeiro. Mais especificamente para o poema XLVII, de "O guardador de rebanhos, quando o poeta nos coloca aquilo que ele entende por verdade. Ouçamos os versos escritos em 1914:

Num dia excessivamente nítido,

Dia em que dava a vontade de ter trabalhado muito

Para nele não trabalhar nada,

Entrevi, como uma estrada por entre as árvores,

O que talvez seja o Grande Segredo,

Aquele Grande Mistério de que os poetas falsos falam.

Vi que não há Natureza,

Que Natureza não existe,

Que há montes, vales, planícies,

Que há árvores, flores, ervas,

Que há rios e pedras,

Mas que não há um todo a que isso pertença,

Que um conjunto real e verdadeiro

É uma doença das nossas ideias.

A Natureza é partes sem um todo.

Isto é talvez o tal mistério de que falam.

Foi isto o que sem pensar nem parar,

Acertei que devia ser a verdade

Que todos andam a achar e que não acham,

E que só eu, porque a não fui achar, achei. ${ }^{407}$

O poema nos leva ao entendimento de que existe uma realidade que se abre aos nossos olhos que é pungente, eloquente, vigorosa e que passa desapercebida. Não se percebe esta gênese da realidade da qual Caeiro é cocriador. A estrutura da

${ }^{406}$ HEIDEGGER, "Hegel e os gregos", in:

${ }^{407}$ PESSOA, Obra Poética, p. 226-227. , Marcas do Caminho, p.451. 
cotidianidade é a de não questionar o habitual. Em nossa existência costumeira andamos desatentos das coisas, só que essa desatenção gera um desacordo. ${ }^{408} \mathrm{~A}$ cotidianidade impede o homem de acordar para a sua essência. A verdade das coisas sempre diz respeito à essência, ao modo próprio de ser desse ente que se mostra como tal, e, toda vez que impera esta desatenção, a coisa fica objetivada. A consequência disto é que, se a coisa está em dissonância com a sua essência, a verdade não vigora. Quando falamos em essência da verdade não podemos pensar que há algo por trás da verdade, a palavra essência deve ser sempre entendida como a força que gera, como gênese. O substantivo essência em alemão é Wesen, que na passagem ao sentido verbal significa algo que dinamicamente está agindo, vitalizando, sendo. Esta manifestação evoca um movimento, uma duração, uma experiência. O termo essência diz sempre vida, dinâmica, força. ${ }^{409}$ Para compreendermos a verdade e sua essência devemos buscar entender o movimento de verdade fazendo-se verdade ou tornando-se verdade, mas, para isso, é preciso estar fincado no modo de ser que é abertura, do contrário, o que vemos é algo derivado, constituído e organizado segundo um modo de ser que apresenta o real objetivadamente. Trata-se de nascer para um determinado modo de ser que nada tem a ver com datação ou historiografia. Isso que é originário espantosamente já se dá como salto, sem um processo lógico-dedutivo. Referimo-nos a uma abertura, a uma visão nítida, capaz de ver o que Caeiro viu: que nada há por trás das coisas a não ser elas mesmas. Não há um Grande Segredo. Não há um Grande Mistério. Não há um todo. Um conjunto não há. O que há são partes - o vale, as montanhas, os rios, as flores. Não existe ou preexiste nada por trás disso como causa. A essência, como dissemos, não é o âmago, o interior ou o núcleo de algo, mas, é a própria dinâmica de algo se tornando algo, é o vigor que irrompe quando algo vem a ser aquilo que é. Nisso não há um fundo, um profundo, é algo que se dá na mais fina linha da superfície. É por isso que Caeiro, sem querer e nem pensar, entendeu a verdade. Ele é partícipe disso que se dá em pura gratuidade. Álvaro de Campos também entendeu que o mistério profundo das coisas jaz “como um óleo à superfície”. Ouçamos seus versos, escritos em 1928:

\footnotetext{
${ }^{408}$ Cf. HEIDEGGER, "Sobre a essência da verdade", in:

${ }^{409}$ Cf. HARADA, Iniciação à Filosofia, p.6. Os Pensadores, p.157.
} 
Às vezes medito,

Às vezes medito, e medito mais fundo, e ainda mais fundo

E todo o mistério das coisas aparece-me como um óleo à superfície,

E todo o universo é um mar de caras de olhos fechados para mim.

Cada coisa - um candeeiro de esquina, uma pedra, uma árvore,

E um olhar que me fita de um abismo incompreensível,

E desfilam no meu coração os deuses todos, e as ideias dos deuses.

Ah, haver coisas!

Ah, haver seres!

Ah, haver maneira de haver seres,

De haver haver,

De haver como haver haver,

De haver...

Ah, o existir o fenómeno abstracto - existir,

Haver consciência e realidade,

$\mathrm{O}$ que quer que isto seja...

Como posso eu exprimir o horror que tudo isto me causa?

Como posso eu dizer como é isto para se sentir?

Qual é alma de haver ser?

Ah, o pavoroso mistério da existência da mais pequena coisa

Porque é o pavoroso mistério de haver qualquer coisa

Porque é o pavoroso mistério de haver... ${ }^{410}$

Campos, assim como Caeiro, expressa sua perplexidade de haver algum mistério.

O mistério é, como dissemos lá atrás, o parar na linha de ocultação e ver na ocultação - enquanto e como ocultação - mostração. A ocultação é um modo de desocultação. O esconder, de mostrar. O não revelar é um modo de tornar visível. Não há um por trás. Por isso, todo o universo é um mar de olhos fechados a fitar o poeta de um abismo incompreensível - que há coisas, que há de haver coisas, que há de haver o haver das coisas... toda essa abstração é coisa do pensar, e "pensar é estar doente dos olhos". Ouçamos, uma vez mais, Caeiro, agora com os versos II, de "O guardador de rebanhos":

[...] Creio no mundo como num malmequer,

Porque o vejo. Mas não penso nele

Porque pensar é não compreender...

O Mundo não se faz para compreendermos

(Pensar é estar doente dos olhos)

Mas para olharmos para ele e estarmos de acordo... $[\ldots]^{411}$

Não há o que pensar, pois pensar é não compreender, diz o poeta. Caeiro conclama um ver que restitui um outro pensar, o pensar que vê o ver. Este pensar destacado pelo poeta é justamente a dimensão problematizada por Heidegger sobre o pensar, por nós tratada no capítulo anterior, quando nos referimos ao pensar como uma

\footnotetext{
${ }^{410}$ PESSOA, Obra Completa: Álvaro de Campos, p.212-213.

${ }^{411}$ Idem, Obra Poética, p.204-205; idem, Obra Completa de Alberto Caeiro, p. 34.
} 
percepção-recepção-ativa, que nada tem a ver com a razão. ${ }^{412} \mathrm{O}$ que há é o ver, é o estar em sintonia e sincronia com o mundo e senti-lo, e, com isso, transpor-se para ele e conascer com ele. Só assim somos partícipes da gênese do mundo, de sua nascença. Neste estar de acordo, há uma entrega que deixa a coisa ser a própria coisa. Neste abandono, há uma aquiescência onde a coisa é, desde ela mesma, ela mesma. Nesta copertinência a coisa vigora, se essencializa. Ambos os poetas falam do despertar do homem para uma realidade em que a realidade não é coisa nenhuma. O que jaz por trás dos versos de Caeiro e Campos é a questão da transcendência que, como vimos, é passagem e salto para uma dimensão própria do homem, na qual este se insere em uma dinâmica de participação do desvelamento da realidade, que é a coisa, que é o ente, que é o mundo. O homem não é uma categoria biológica, sociológica ou antropológica. Não! O homem é um acontecimento que irrompe, cumula e plenifica quando realiza o seu limite, aquilo que ele pode ser. Nesse acontecimento, o homem chega maximamente a sua humanidade. Ele realiza extraordinariamente aquilo que ele é. Isto é o ápice da liberdade humana! Heidegger chamou isso de acontecimento apropriador. A palavra em alemão para este acontecimento é Ereignis. No uso comum, significa evento, acontecimento. Em sua etimologia, o termo é composto pelo prefixo de intensificação $E r$ - e por -eigen que significa próprio. Podemos, pois, inferir que ao pé da letra Ereignis é o mais próprio. A forma verbal é ereignen e diz respeito ao apropriar, ao tornar próprio. ${ }^{413}$ Segundo Carneiro Leão, Ereignis origina-se em er-äug-nis, do verbo äugen. A forma substantiva de äugen é Auge, olho, no sentido da capacidade que tem a condição humana de apreender a transformação da realidade que se manifesta, de ver o que se revela. Ereignis nos fala, então, do por à vista, do mostrar, do revelar, do desocultar, do sair do encoberto, do mostrar-se do ser em sua originariedade, "é o espetáculo de Ser manifestando a Verdade" ${ }^{114}$, uma dinâmica integradora de forças de vigor e realização da criação humana. Trata-se de um processo de abertura que se mostra, possibilitando uma visão. Mais do que apropriar-se, é o deixar-se apropriar pelo ser em sua originariedade, apropriação a partir da qual e pela qual homem e ser estão entregues mutuamente um ao outro como propriedade, em uma

\footnotetext{
${ }^{412}$ Cf. p. $132-133$.

${ }^{413}$ Cf. SCHUBACK, nota do tradutor, in: HEIDEGGER, "O caminho para a linguagem”, in: A Caminho da Linguagem, p.209.

414 CARNEIRO LEÃO, O último Heidegger [inédito], p.15-19. Maiúsculas do autor.
} 
(comum)unidade. ${ }^{415}$ Ereignis é uma palavra chave que abre inúmeras portas, mas, assim como a palavra grega lógos e a chinesa Tao, pouco se deixa verter para outra língua. ${ }^{416}$ Como vemos, este acontecimento ímpar não é algo assim tão simples e atravessou o pensamento do filósofo ao longo de toda a sua vida. Aparece nos escritos de Heidegger por volta dos anos 1934-1936 e vai até o seminário sobre a conferência "Tempo e Ser", em 1962.417 O germinar deste pensamento já está esboçado em Ser e Tempo quando, em 1927, prenuncia: "Esta abertura própria mostra o fenômeno da verdade mais originária no modo da propriedade. $A$ verdade da existência é a abertura mais originária e mais própria que o poder-ser da presença pode alcançar." ${ }^{418}$ Isto significa que o mostrar-se, o desencobrir-se da existência do homem no modo de ser que é o mais próprio está fundado na verdade do ser, de tal modo que é o próprio ser que conclama para a história. ${ }^{419}$ Isto é ser pleno, é ser completo, é realizar tudo que se pode realizar no exercício do próprio da existência enquanto tal. Quando se dá esse mais próprio, a vida é exemplarmente vida. É envio. É destino. É história. Este é o tempo do ser. ${ }^{420}$ Este é o tempo de ser no modo do sentido do ser - no modo em que se está inserido no ser, aberto para ele, em uma relação de pertença para com ele. Mas como é isso? O ser se presentifica no mundo como um campo de presença. Não que o ser se desdobre na possibilidade de uma captura, sabemos que é constitutivo do ser a subtração e a retração, portanto, tratase de um campo de presença minado por uma ausência. Todavia, nesse presentificar da presença, enquanto e como ausência, o ser se doa em favor do ente como dádiva, como dom, em pura gratuidade. ${ }^{421}$ Dá-se o ser! Isso é um acontecimento extraordinário que é direção, destino, história. Esta última, lembrando o que dissemos no início deste capítulo, não dentro de uma dimensão ôntica relativa aos acontecimentos que se dão no interior do tempo e que demarcam o acontecimento historial da humanidade, mas em uma dinâmica existencial que se faz de modo originário com o mundo e com o ser. É o Ereignis que demarca o início da história do homem sendo o seu mais próprio. É o Ereignis que consuma o desvelamento do

\footnotetext{
${ }^{415}$ Cf. HEIDEGGER, "O princípio da identidade", in:

${ }^{416}$ Cf. Ibidem, p. 180. , Os Pensadores, p.177.

417 Marlène Zarader faz um excelente levantamento, por ordem cronológica, dos textos que tratam o tema. A autora diferencia aqueles em que o Ereignis é meramente evocado daqueles em que o assunto é explicitado. Cf. ZARADER, Heidegger e as Palavras da Origem, p.329.

${ }^{418}$ HEIDEGGER, Ser e Tempo, p.292. Itálicos do autor.

${ }^{419}$ Cf. HEIDEGGER, Contribuições à Filosofia, p.54.

${ }^{420}$ Ibidem, p.492.

${ }^{421}$ Cf. VATTIMO, As Aventuras da Diferença, p.123. Grifo do autor. Itálico nosso.
} 
ente em sua totalidade. Isto é vida. É existência. É liberdade. É história. Tudo o que dissemos até aqui é insuficiente para falar deste acontecimento extraordinário. Não há como definir o Ereignis através de um enunciado propositivo, muito menos, falar cartesianamente, de modo claro e distinto. Trata-se, com margem a uma imprecisão bastante grande, de um acontecer originário, "o âmbito dinâmico em que homem e ser atingem unidos sua essência (e) conquistam seu caráter historial [...]." ${ }^{{ }_{422}}$ Há, pois, neste acontecimento uma apropriação do homem e do ser em uma (com)unidade essencial, a qual determina o modo de ser do homem e todo o seu destino. Tudo aquilo que ele pode ser e nada mais. Mas não só isso! Esse nada mais não fala de um menos, ao contrário, este é um menos que é mais, pois este acontecimento perpassa a saga do dizer. "A linguagem”, nos diz Heidegger, "é a ressonância que pertence ao acontecimento apropriador" ${ }^{423}$, assim, ao apropriar o apropriado, o acontecimento apropriador torna própria a própria palavra anunciadora que se desdobra na saga mostrante do dizer e "en-caminha a linguagem para a fala do homem. A saga do dizer recomenda a verbalização sonora na palavra" ${ }^{24}$, ele diz. O caminho para a linguagem originária se determina a partir desse deixar-ser que eclode no dizer do poeta a sua força de mostração. É nesta proximidade que poeta e poesia são remetidos ao mais próprio de suas essências, de suas forças geradoras, de seu vigor. Só que para poder ser tomado pelo tomável, há que ser fraco, frágil, há que passar pela angústia originária, pela experiência da finitude, da radicalidade do nada. A saga do dizer se faz a partir desse silenciar. É o silêncio que mantém e estabelece os critérios da medida. ${ }^{425}$ É o silêncio do nada a se desdobrar em escuta que pode anunciar a saga do dizer. Só aí o homem pode dizer que habita em sua morada. Só aí ele habita a casa do ser.

Paul Klee, em Sobre a Arte Moderna e outros Ensaios, nos traz uma analogia muito interessante que exemplifica de modo magistral aquilo que queremos expressar com a ideia de habitação, morada. Assim, ele diz:

Deixe-me usar uma metáfora, a metáfora da árvore. Pelo que podemos supor, o artista dedicou toda a sua atenção a esse mundo multiforme, e de alguma maneira encontrou o seu caminho nele. Com toda calma. Ele tem um senso de orientação tão bom que é capaz de organizar a passagem fugidia dos fenômenos e das

\footnotetext{
422 HEIDEGGER, "O princípio da identidade", in: Os Pensadores, p.181. Mais à frente, retomaremos a questão quando finalmente chegarmos à questão do tempo.

${ }^{423}$ HEIDEGGER, Contribuições à Filosofia, p.481.

${ }^{424}$ HEIDEGGER, "O caminho para a linguagem", in:

${ }^{425}$ Cf. HEIDEGGER, op. cit., p.494. , A Caminho da Linguagem, p.214.
} 
experiências. Essa orientação nas coisas da natureza e da vida, essa organização ramificada e diversificada, é o que eu gostaria de comparar à raiz da árvore. Dessa raiz afluem para o artista as seivas vitais que vão passar através dele e através dos seus olhos. Portanto, ele ocupa o lugar do tronco. Pressionado e movido pelo poder daquele fluxo, ele encaminha o que foi vislumbrado para a obra. [...] Ocupando o lugar que lhe cabe - no tronco da árvore - tudo que ele faz é recolher e encaminhar aquilo que vem das profundezas da terra. Não servir nem dominar: apenas comunicar. Portanto ele assume uma posição realmente humilde. E a beleza da copa não lhe pertence, apenas passa através dele. ${ }^{426}$

A belíssima, porém, longa descrição sobre a obra de arte nos fala da inserção do artista neste processo: ele é o tronco dessa árvore, ele é a passagem para a obra. Nada aqui nos reporta a uma autonomia da consciência, a uma subjetividade. Tratase, como foi dito anteriormente, de um modo de ser que não é nem ativo e nem passivo, mas, de um comportamento que é concedido como irrupção, acontecimento, que, acontecendo, faz aflorar o que é o mais próprio e que deixaser. É através desse acontecimento que a obra de arte se origina. É a partir dessa irrupção que a obra é o que é e como é. Nisso consiste a proveniência da sua essência: a obra surge através do artista e este, por sua vez, surge através da obra, ou melhor, "o artista é a origem da obra. A obra é a origem do artista. Nenhum é sem o outro." ${ }^{427}$ Ambos coexistem graças à arte. Nisso há uma aguda e radical experiência - a experiência da essência da verdade - a se desdobrar em modos de ser e formas do criar. O poetar também é isso. A inicialidade da palavra advém desta experiência; advém do deparar-se com a radicalidade de ser tocado e tomado pela palavra e pela acolhida daquilo que vem ao nosso encontro sem a nossa interposição. ${ }^{428}$ Isto é a saga da inicialidade do dizer. O dizer originário antes de ser mostração é silêncio - escuta - acolhida. Quando o dizer está sintonizado com essa irrupção, a linguagem poética mostra, põe a coisa tal como ela é. "É neste silêncio anterior à palavra que Caeiro deseja repousar"'429, diz Lourenço. Esta será sempre uma linguagem original, inaugural, que nasce com o surgimento das coisas, esta é a genuína linguagem que se faz desde como experiência da linguagem. A saga do dizer torna possível e sustenta a possibilidade para todo o ser, pois é somente na palavra que as coisas são. É somente no nomear do poeta que palavra é palavra. Ouçamos Caeiro, no famoso trecho de “O guardador de rebanhos”, escrito em 1914:

\footnotetext{
${ }^{426}$ KLEE, Sobre a Arte Moderna e outros Ensaios, p.52-53.

${ }^{427}$ HEIDEGGER, "A origem da obra de arte", in:

${ }^{428}$ HEIDEGGER, Contribuições à Filosofia, p. 158. , Caminhos de Floresta, p.8.

${ }^{429}$ LOURENÇO, Pessoa Revisitado, p.54.
} 
Porque o único sentido oculto das coisas,

É elas não terem sentido oculto nenhum,

É mais estranho do que todas as estranhezas

E do que o sonho de todos os poetas

E os pensamentos de todos os filósofos,

Que as coisas sejam realmente o que parecem ser

E não haja nada que compreender.

Sim, eis o que os meus sentidos aprenderam sozinhos -

As coisas não têm significação: tem existência.

As coisas são o único sentido oculto das coisas. ${ }^{430}$

O que o poeta está anunciando é que a coisa é pura irrupção, eclosão, existência, presença. Não há nada por trás. Não há um sentido oculto ou algo a compreender. "A natureza", completa Lourenço, "é só o muro nu do existir."431 A linguagem de Caeiro personifica a mais autêntica concretização dessa abertura. Ao nomear, a linguagem do poeta dá existência. Isto significa que "a poesia é fundação por meio da palavra e na palavra." ${ }_{432}$ Não nos referimos aqui ao simples designar de um nome a algo anteriormente conhecido. Referimo-nos, sim, a uma palavra essencial que ao ser pronunciada diz, pela primeira vez, o ente naquilo que ele mesmo é. Nesse chamado evoca-se a coisa naquilo que ela é. É neste sentido que Heidegger diz que a poesia funda o ser pela palavra. Quando o poeta fala das coisas elas são. A coisa só passa a ter existência se há uma sintonia que a sente e a torna visível, pois, coisa só se mostra como coisa nesta abertura. Deixar a coisa ser é colocar-se na mesma abertura. Esta é uma questão crucial em relação à verdade, pois, “é somente desta possibilidade intrínseca da abertura do comportamento que a conformidade da proposição recebe a aparência de realizar a essência da verdade. ${ }^{{ }^{4} 33}$ É somente a partir desta abertura que a medida orientadora manifesta a possibilidade da conformidade com a enunciação. "A saga do dizer não se deixa aprisionar por nenhum enunciado" ${ }^{434}$, diz Heidegger. Logo, o enunciado é tardio, epigonal, não é, de modo algum, o lugar da verdade originária. Este lugar recai sobre a própria relação do poeta com a palavra. É a palavra que contém a "articulação protetora da verdade do ente em sua totalidade. ${ }^{{ } 435}$ É a palavra que guarda o ser. É ela o lugar em que os deuses aparecem - o próprio lugar da saga do dizer, na medida em que

\footnotetext{
${ }^{430}$ PESSOA, Obra Poética, p. 223; idem, Obra Completa de Alberto Caeiro, p.66.

${ }^{431}$ LOURENÇO, Pessoa Revisitado, p.54.

${ }^{432}$ HEIDEGGER, Explicações da Poesia de Hölderlin, p.51.

${ }^{433}$ HEIDEGGER, "Sobre a essência da verdade", in:

${ }^{434}$ HEIDEGGER, "O caminho para a linguagem”, in: , Os Pensadores, p.159.

435 Ibidem, p. 168. , A Caminho da Linguagem, p.214.
} 
deixa-ser, em que confere vigência de modo a nos ofertar a coisa como coisa. A linguagem de Caeiro, diz Osakabe, é aquela que se põe neste fluxo verbal: "os poemas fluem quase como se fosse uma prosa livre, sem linguagem figurada, sem adornos, sem sofismas", resultam "da constituição de uma espécie de estilo zero, sem marcas de realce, sem grandes exaltações, [...] uma sintaxe tão direta e tão plena, como se tudo só pudesse ser dito na forma do vento que passa ou do rio que flui. ${ }^{\circledR 36}$ Este fluxo verbal que corre livremente nos poemas de Caeiro traduz a íntima relação do poeta com a palavra. É a palavra que faz aparecer o que foi contemplado pelo poeta. ${ }^{437}$ Mas o que foi contemplado?

\subsection{Antes do nome}

De modo a pavimentar o caminho, deixemos de lado temporariamente a pergunta e voltemos nossos ouvidos para o versículo que inicia o belíssimo prólogo do Evangelho de João:

No princípio era o Verbo

e o Verbo estava com Deus

e o verbo era Deus. ${ }^{438}$

João escreve seu relato no primeiro século. Sua língua era o grego. Isto tem um significado bastante grande, pois, em grego, verbo é lógos. Assim, no princípio era o lógos e o lógos estava em Deus. Evidentemente, não há nesta narrativa nenhuma explicação lógico-formal. João recupera o relato da criação que diz que Deus criou o mundo por seu Verbo, por sua Palavra. O que Deus disse e proclamou foi feito. Queremos destacar que palavra e ação estão aqui evidenciados. São inúmeras as narrativas no Antigo Testamento sobre a Palavra criadora de Deus - no livro dos Salmos encontramos: "O céu foi feito com a palavra de Iahweh e seu exército com o sopro de sua boca [...] porque ele diz e a coisa acontece, ele ordena e ela se afirma" 439 ; o livro da Sabedoria de Salomão também diz: "Deus dos Pais, Senhor de misericórdia, que tudo criaste com tua palavra [...]" ${ }^{\text {440; }}$; em Eclesiástico, lemos:

\footnotetext{
${ }^{436}$ OSAKABE, Fernando Pessoa: Entre Almas e Estrelas, p.32 e 63, respectivamente

${ }^{437}$ Cf. HEIDEGGER, “A palavra”, in: __ A Caminho da Linguagem, p.188.

438 Jo. 1-1.

439 Sl. 33, 6-9.

440 Sb. $9-1$.
} 
"Por suas palavras o senhor fez suas obras[...]"441. Tais relatos reportam-se às primeiras manifestações da doutrina da palavra criadora. Por certo, não voltaremos nossa atenção para uma exegese ou mesmo um aprofundamento das perícopes citadas, nosso intuito é falar da palavra em sua gênese. Além disso, esta não é uma prerrogativa das tradições religiosas ocidentais. As mais diversas tradições atribuem ao Deus criador o poder primordial de produzir e dirigir todas as coisas. Milhares de anos antes da era cristã, nos escritos primitivos da civilização egípcia, sabemos da existência de um ser espiritual denominado Ptá que pensou o mundo e usou a palavra como forma de gerar vida psíquica e corpórea a tudo o que existe. No estudo de Ernest Cassirer, intitulado Linguagem e Mito, encontramos a compreensão de que, em um estágio mítico da humanidade, as palavras continham uma dimensão mágica capaz de conferir poderes de criação. Ele diz:

Nos relatos da Criação de quase todas as grandes religiões culturais, a Palavra aparece sempre unida ao mais alto Deus criador, quer se apresente como o instrumento utilizado por ele, quer diretamente como o fundamento primário de onde ele próprio, assim como toda a existência e toda a ordem de existência provém. O pensamento e sua expressão verbal costumam ser aí concebidos como uma só coisa, pois o coração que pensa e a língua que fala se pertencem necessariamente. ${ }^{442}$

Há nestas palavras o entendimento de que palavra e criação andam juntas. É pela palavra que as coisas têm vida, existência. Para Cassirer, há uma copertença entre o pensamento e a linguagem. O pensador alemão se refere ao coração que pensa e à língua que fala como uma só e única coisa. Isto significa que a gênese de tudo que é e há se dá pelo pensamento do coração e pelo mandamento da língua. Poderíamos inferir que no coração que pensa há algo da ordem do sentir, do perceber, da percepção, e que é a copertença do pensar com o dizer que manifesta a existência das coisas. Este é também o entendimento de Paz, em O Arco e a Lira, quando, logo no início do capítulo intitulado "A Linguagem”, nos fala que no rito mágico da fala criava-se a realidade e "a pronúncia exata das palavras mágicas era uma das primeiras condições da sua eficácia." ${ }^{443}$, referindo-se ao fato de que palavra e coisa andavam juntas.

Nas palavras dos mais diversos narradores o Verbo, o lógos, aparece como a força que gera, a força que cria. Esta afirmação abre-nos para tudo o que existe.

\footnotetext{
${ }^{441}$ Eclo. $42,15$.

${ }^{442}$ CASSIRER, Mito e Linguagem, p.65.

${ }^{443}$ PAZ, O Arco e a Lira, p.37.
} 
Tudo o que é e há foi criado pela palavra criadora. Todas as coisas, todas as criaturas tiveram vida pela palavra. À parte de todo o caráter figurativo e simbólico desta afirmação, o fenômeno da linguagem foi tema e interesse de diversas áreas do conhecimento humano. A biologia, sociologia, a antropologia filosófica e a própria teologia, entre outras ciências, buscaram tornar compreensível e elucidar de modo amplo este fenômeno. Trata-se de formulações que buscam esclarecer os paradigmas que caracterizam como a linguagem se manifesta. Por isso, não é errôneo dizer que a linguagem é expressão sonora, é atividade humana, é comunicação da alma, entre tantas outras definições. O problema é que o resultado desses saberes se firma como verdades inabaláveis. Tais investigações não se voltam para a própria essência da linguagem, ou melhor, as observações científicas não refletem sobre a linguagem como linguagem. ${ }^{444} \mathrm{E}$ não só isso! Todas estas análises partem da ideia de que é o homem o protagonista, o sujeito da fala.

Partimos da palavra como criação, como princípio de realidade - uma palavra que, ao mesmo tempo que cria, anuncia e revela o sentido. Isto a que queremos nos reportar é perfeitamente compreendido por João Guimarães Rosa quando, em longa entrevista conduzida por Günter Lorenz, no Congresso de Escritores Latino-Americanos, em janeiro de 1965, diz:

Somente renovando a língua é que se pode renovar o mundo. Devemos conservar o sentido da vida, devolver-lhe esse sentido, vivendo com a língua. Deus era a palavra e a palavra estava com Deus. Este é um problema demasiado sério para ser largado nas mãos de uns poucos ignorantes com vontade de fazer experiências. $\mathrm{O}$ que chamamos hoje linguagem corrente é um monstro morto. A língua serve para expressar ideias, mas a linguagem corrente expressa apenas clichês e não ideias; por isso está morta, e o que está morto não pode engendrar ideias. ${ }^{445}$

O longo trecho nos fala exatamente do sentido da palavra, da palavra como doadora de sentido. Para Guimarães Rosa, a palavra encontra-se esvaziada, aquilo que vem à fala é sempre o repetitivo, o recorrente, algo que se arrasta pela linguagem até virar clichê. Isso nos retira do habitar essencial da palavra. Nosso repertório está repleto de termos que chegam até nós vazios de sentido, exatamente como num poço seco. Pertencem à ordem sonora do sensível, são ditos na nossa fala, mas orbitam fora do registro essencial da palavra, pois estão, na maioria das vezes, enraizados em ideias preconcebidas que circunscrevem de modo limitante a fala do

${ }^{444}$ Cf. HEIDEGGER, “A Linguagem”, in: , A Caminho da Linguagem, p.11.

${ }^{445}$ LORENZ, "Diálogo com Guimarães Rosa", in: COUTINHO, Guimarães Rosa, p. 88. 
homem. O sentido das palavras pertence à ordem do não sensível, e é somente quando o termo está pleno de sentido que ele se torna uma palavra. De acordo com Heidegger,

as palavras não são termos ou coisas semelhantes a baldes e tonéis dos quais retiramos conteúdos preexistentes. As palavras são poços que o dizer cava, poços novos a achar e cavar de tempos em tempos, que facilmente se fecham, mas de vez em quando também jorram. Sem essa ida contínua aos poços, os baldes e tonéis ou permanecem vazios ou seu conteúdo estagnado. ${ }^{446}$

Por isso, a linguagem está morta, e qualquer tentativa de investigação sobre a linguagem está comprometida, na medida em que se parte de pressupostos que, como vimos, restringem o estatuto da linguagem ao de instrumento e sua função à de expressão do pensamento. Na contramão de tudo isso, escutamos a frase: "A linguagem fala" ${ }^{447}$, proferida por Heidegger, na palestra em memória a Max Kommerell, em 1950, intitulada “A Linguagem”. Esta é uma frase no mínimo intrigante, uma vez que nossos ouvidos estão habituados ao seu contrário - "o homem fala" é o que soa lógico e habitual. Entretanto, o lógico e o habitual não fazem morada no pensamento do filósofo alemão. Falamos da essência da linguagem, sua força geradora, motriz. Acercamo-nos do poder do lógos, do privilegiado dizer em seu processo apofântico, do simples ato de deixar aparecer, do emanar daquilo que se mostra, permitindo o desabrochar da essência das coisas, com isso, tornando-as reais. Por certo, não nos referimos à palavra homogeneizada e petrificada na página de um dicionário. Nem tampouco, ao falarmos da linguagem temos em mente uma filosofia da linguagem com seus preceitos e determinações. Buscamos, sim, refletir sobre a linguagem, a partir da palavra como origem, como vigência da verdade do ser, como aquilo que sem nome para vir a ser real precisa ser nomeado. Por isso, a pergunta: o que é nomear? Por certo, não é apenas dar um nome a um objeto ou a algo. Pensando assim, estaríamos dentro de uma compreensão sujeito/objeto, onde a palavra apenas tem o sentido de comunicar algo previamente estabelecido. Walter Benjamin, no ensaio de juventude intitulado "Sobre a linguagem em geral e sobre a linguagem do homem", escrito em 1916, entende que o nome se encontra num patamar bastante elevado - ele é a essência da língua. No nome, a língua comunica a si mesma, em sua absoluta totalidade. Ressaltamos que não é através do nome, mas é no nome que a língua comunica a

\footnotetext{
${ }^{446}$ HEIDEGGER, Que Chamamos Pensar? [inédito], p.109.

${ }^{447}$ HEIDEGGER, “A Linguagem”, in: , A Caminho da Linguagem, p.9.
} 
si mesma. O nome não é o meio para comunicar algo a alguém, mas "no nome a essência espiritual do homem se comunica a Deus." ${ }^{448}$ Benjamin defende a ideia de que quanto mais aprofundada a existência do homem mais exprimível ele é. Daí afirmar a absoluta e unívoca relação entre espírito e linguagem, de tal forma que

aquilo que existe com mais força na linguagem, aquilo que está melhor estabelecido, aquilo que é, em termos de linguagem, mais pregnante e inarredável, em suma, o que mais se exprime, é ao mesmo tempo o espiritual em sua forma pura. ${ }^{449}$

Apesar da terminologia aqui empregada, entendemos que a compreensão de Benjamin se aproxima, em muito, do que queremos expressar com o famoso dito de Heidegger sobre a linguagem. Quando Heidegger diz que a linguagem fala, há uma sacralidade neste falar, uma sacralidade que faz revelar algo que não estava presente. Sobre o nomear, ouçamos o próprio Heidegger: "Nomear é evocar para a palavra. Nomear evoca. Nomear aproxima o que se evoca. [...] A evocação convoca. Desse modo, traz para uma proximidade a vigência do que antes não havia sido convocado." ${ }^{450}$ Em outra ocasião, ele diz: "Nomear é aclarar, trazer à luz, por a descoberto." ${ }^{451} \mathrm{O}$ nomear evoca para a palavra, chama pelo nome, aproxima, faz aparecer. O nomear traz à presença o que estava ausente, torna visível a coisa como coisa. O nomear torna a palavra exemplarmente palavra e não apenas uma representação, um símbolo ou algo que se apresenta no lugar de algo. Assim como para Heidegger, Benjamin também entende que a linguagem jamais fornece meros signos, pois "o nome que o homem atribui à coisa repousa sobre a maneira como ela se comunica a ele." ${ }^{\$ 52}$ Isto quer dizer que não é o homem que diz o que a coisa é, ao contrário, é a coisa que comunica ao homem aquilo que ela é. Há nesta relação uma receptividade ativa que traduz aquilo que não tem nome para a palavra. Segundo Benjamin, é nesse átimo que a criação divina se completa, e, a partir do homem, no nome, que a linguagem fala. ${ }^{453}$ Então, perguntamos: onde a palavra se mostra distintamente como tal? É na poesia que a palavra é eminentemente palavra. A poesia é a mais pura dinâmica de realização de realidade. Como vimos, esse

\footnotetext{
${ }^{448}$ BENJAMIN, "Sobre a linguagem em geral e sobre a linguagem do homem", in: , Escritos sobre Mito e Linguagem, p.55.

449 Ibidem, p.59.

${ }^{450}$ HEIDEGGER, "A linguagem", in:

${ }^{451}$ HEIDEGGER, Heráclito, p.260. , A Caminho da Linguagem, p.15-16.

${ }^{452}$ BENJAMIN, op. cit., p.63.

${ }^{453}$ Cf. Ibidem, p.56.
} 
revelar-se da coisa como tal é alétheia e nada tem a ver com um estado de coisas verificáveis. É desvelamento, desocultação, mostração. Busquemos abrigo nos versos de Caeiro, escritos em 1919:

Criança desconhecida e suja brincando à minha porta,

Não te pergunto se me trazes um recado dos símbolos [...].

Aprecio a tua presença só com os olhos.

Vale mais a pena ver uma coisa sempre pela primeira vez que conhecê-la,

Porque conhecer é como nunca ter visto pela primeira vez,

E nunca ter visto pela primeira vez é só ter ouvido contar [...].

Brinca! Pegando numa pedra que te cabe na mão,

Sabes que te cabe na mão.

Qual é a filosofia que chega a uma certeza maior?

Nenhuma, e nenhuma pode vir brincar nunca à minha porta. ${ }^{454}$

Aqui, o poeta fala do frescor de ver pela primeira vez. Não quer saber dos símbolos. O símbolo não é a coisa! O símbolo, como vimos em nosso segundo capítulo, é o representante da coisa, é o que nos remete e envia para a coisa, é o instrumento de mediação entre a coisa e seu significado. A criança aqui aparece de modo a exaltar o espanto, a relação direta com a coisa, sem a interposição do pensamento ou de uma ideia pré-concebida. Não há mediação! Não interessa a Caeiro o poder do conhecimento sobre um objeto que é sempre dado através de uma captação e de uma representação, o que vale é a experiência de pegar a pedra, de tê-la na mão, de senti-la como pela primeira vez, de saber que ela te cabe e se aquiescer com esse pouco. Não se pode de fora falar sobre a coisa, mas somente e na medida em que se está junto a ela e é por ela atravessado. Na visão do poeta, nenhuma filosofia supera aquilo que nos é dado pela experiência. Nela, o poeta participa da coisa. A participação é, pois, fundamental para que a palavra poética possa ser princípio de realidade. É nesta experiência de participação que o poeta funda e instaura a linguagem originária. Tendo tudo isso em mente, retomemos agora a pergunta deixada no final da primeira parte deste capítulo: o que a visão de Caeiro contemplou?

Vejamos o que diz um de seus discípulos. António Mora nos conta que "na obra de Caeiro, há mais uma filosofia do que uma arte. Reaparece nele a primitiva grega forma de filosofar pela poesia." ${ }^{455} \mathrm{O}$ ver do poeta de "O guardador de rebanhos" é rigorosamente o ver fenomenológico; sua poesia abre, mostra e revela

${ }_{454}$ PESSOA, Obra Poética, p.232; idem, Obra Completa de Alberto Caeiro, p.106-107.

${ }^{455}$ MORA, "O regresso dos deuses", in: PESSOA, O Regresso dos Deuses, p.56. 
que por trás do fenômeno não há nada. É pura superfície. Mas para ver tem que estar em total sintonia com a dimensão a partir da qual a coisa se mostra como ela mesmo é. Isto significa transpor-se para um âmbito vital existencial que é a de ser partícipe e de insistir nessa participação. "Nesta participação", diz Heidegger, "decide-se, a priori e constantemente, o modo como somos aquilo que fazemos." ${ }^{\text {"56 }}$ O poeta precisa, pois, tomar parte da poesia, estar dentro da poesia. É preciso o interesse - que vê sempre e desde dentro do modo de ser que é o da própria poesia - para trazer à linguagem o dito poético. Isto significa que o estar dentro da coisa, aquilo que põe o como da coisa, é prévio àquilo que é a palavra poética, ou seja, quando a palavra se faz, já se instaurou o modo de se relacionar com a coisa, e o que assim é dito é verdadeiro, original. ${ }^{457}$ Entretanto, isto não significa que o poeta é a causa ou o sujeito da poesia. Sobre isso, nos diz Lourenço: "Pessoa não escreveu para vencer qualquer coisa de nomeável, mas para nomear aquilo mesmo que visionado determinou o fabuloso fracasso de que os poemas são o lugar e o signo de uma redenção sem redentor." ${ }^{458}$ Segundo o intérprete, Pessoa nunca imaginou que aquilo que ele buscava tivesse de fato tomado forma nos poemas. Sabemos que o que dá a medida do dito poético é a abertura. A verdade se dá no âmbito do aberto; só que o poeta não possui este âmbito, ele se põe nesta dimensão, ele é o lugar e a hora dessa abertura, mas ele só tem o que se abriu e, no mesmo átimo, se ocultou. Como vimos, a palavra alétheia nos fala que, no vigor constante do aparecer, algo permanece encoberto. Ver é, pois, poder ver junto, no mesmo ato, o desvelar e o velar. O poeta é este porta-voz que se coloca no mesmo lógos, no mesmo sentido, na mesma abertura, e, por esta via, "a linguagem fala, nomeia, faz-se palavra, quer dizer, diz, mostra, revela, faz ou torna visível. Enfim, dá-se, aparece"459, diz Fogel, em O Desaprendizado do Símbolo.

Voltemo-nos agora para uma palavra que vimos utilizando com bastante liberdade sem, contudo, a ela nos reportar. Dissemos que o Verbo é lógos. Dissemos também que o poeta é aquele que se coloca no mesmo lógos. Mas o que é lógos? Em que medida ele determina o homem? São muitas as passagens em que Heidegger se refere ao lógos e faz menção à obscuridade do termo. Sabemos que

\footnotetext{
${ }^{456}$ HEIDEGGER, Hinos de Hölderlin, p.62.

${ }^{457}$ Cf. HEIDEGGER, "Sobre a essência da verdade", in:

${ }^{458}$ LOURENÇO, Pessoa Revisitado, p.29.

${ }^{459}$ FOGEL, O Desaprendizado do Símbolo, p. 38. , Os Pensadores, p.159.
} 
esta é uma palavra intraduzível para o pensador alemão. Apesar da dificuldade inerente à compreensão desta palavra, façamos um esforço, de modo a trazer alguma luz para o vocábulo grego. Sabemos que, inicialmente com Platão e depois com Aristóteles, considerado o pai da Lógica, há uma relação do lógos com a Lógica que foi deveras nociva para a linguagem na medida em que vigorou e pretendeu ser a regra de todo o pensar do homem. ${ }^{460}$ Historicamente, o lógos tem a ver com o aparecimento da linguagem. Lógos é verbo, sua forma verbal, légein, significa dizer, entretanto, esta compreensão esconde algo de enigmático, pois, apesar de ambas as formas se referirem à linguagem, nenhuma das duas se refere ao linguístico. Há nesta única palavra abismos não trilhados de uma “interpretação exímia da essência da palavra e do dito" ${ }^{461}$, os quais foram bem compreendidos na aurora grega. Na busca de um sentido originário, Heidegger vê no lógos, cuja raiz latina legere virou lesen no alemão, o sentido de acolher, reunir, concentrar, recolher, colher, apanhar e suspender do chão para guardar. O sentido de ler - como a reunião de letras em palavras, de palavras em frases e frases em unidades de sentido - é apenas um derivado do ajuntar, apesar de ter tomado o primeiro plano, por conta da raiz latina e alemã. Apesar de ser claro para o nós o significado de colher, ainda não estamos circunscritos àquilo que Heidegger tem em mente. Para o pensador, esse "colher" significa "reunir diversas coisas esparsas em uma unidade e ao mesmo tempo trazer essa unidade para junto de e dispô-la [...] para o desvelado do vir à presença." ${ }^{462}$ A experiência primordial arcaica presente neste vocábulo é a concentração, a reunião da pluralidade de unidades, o conjunto de forças recolhidas dentro de uma dinâmica de realização do real. Essa dinâmica de reunião recolhe em si mesma e traz à luz o que se encontrava velado. Referimo-nos aqui à força inaugural de integração da vida humana, ao raio inaugural proclamado por Heráclito, quando diz: "O raio conduz todas as coisas que são." ${ }^{463}$ A partir desta compreensão originária, o lógos se apresenta como a coleta, colheita, o lugar que recolhe, concentra, o centro predominante que tudo reúne e para onde tudo converge, por si mesmo e em si mesmo, e a partir do qual vem à presença e torna

\footnotetext{
${ }^{460}$ Cf. HEIDEGGER, Lógica, p. 254.

${ }^{461}$ HEIDEGGER, "A essência do conceito de phýsis em Aristóteles", in: Caminho, p.292.

462 Ibidem, p.291.

${ }^{463}$ HERÁCLITO, frag.64, in: Heráclito, p.75. , Marcas do Os Pensadores Originários: Anaximandro, Parmênides,
} 
manifesto no vigorar que acontece na linguagem criadora de mundo. É preciso também lembrar que o lógos e o mythós foram usados na origem grega com o mesmo significado, e que, apesar de considerado ingênuo, o mythós encobre as experiências originárias que ocorrem exatamente onde estas tocam o âmago da dimensão humana ${ }^{464}$ Cassirer nos lembra que em quase todas as cosmogonias, por mais longe que remontemos na história mítica, sempre voltamos a nos deparar com uma posição suprema do lógos - lugar em que este "se converte numa espécie de arquipotência, onde radica todo o ser e todo acontecer. ${ }^{465}$ A relação entre o lógos e o mythós só deixou de existir quando a Lógica atravessou o lógos e esvaziou a linguagem de sua essência, de sua força. Há, pois, algo desde o primórdio entre os gregos que ficou esquecido e que nenhuma historiografia pôde avaliar. Para Heidegger, este fenômeno constitui a situação-limite da nossa existência. ${ }^{466}$ Apesar de inapreensível e de suas traduções não esgotarem todas as camadas de significação, é em Heráclito, que encontraremos a experiência da palavra grega lógos em toda a sua riqueza. O pensador de Éfeso se volta para essa palavra de modo a transmitir a totalidade da dinâmica das dimensões humanas, de trazer à luz a dinâmica do ser e do não-ser, da integração de opostos que perfaz a totalidade da experiência humana. Referimo-nos a uma experiência radical de concentração que se exerce nesta dinâmica de unidade dentro de uma multiplicidade, de uma integração entre identidade e diferença, mencionada no início do capítulo. Voltemonos mais precisamente ao fragmento 50. Nele, ouvimos: “Auscultando não a mim, mas ao lógos, é sábio concordar tudo ser um." ${ }^{467}$ Reparemos, de imediato, que o pensador de Éfeso usa o verbo auscultar, escutar, ouvir. Ele adverte ao ouvinte que não é a ele que se deve ouvir, mas ao lógos. Há, pois, uma escuta que se interpõe de modo a que se ouça o que o lógos tem a dizer. Como vimos no capítulo anterior, não se trata de uma escuta qualquer. Não falamos de sons e ruídos. Ao se referir a Heráclito, Heidegger usa o verbo gehören (pertencer), uma palavra que deriva de hören (escutar) e nos remete de imediato à escuta como um pertencimento. Não se trata de uma escuta ligada aos ouvidos, mas, na realidade, de um pertencimento que se faz escuta obediente em relação àquilo que chega até nós. ${ }^{468}$ Lembremos que a

\footnotetext{
${ }^{464}$ Cf. HARADA, Coisas, velhas e novas, p. 132.

${ }^{465} \mathrm{Cf}$. CASSIRER, Linguagem e Mito, p.64.

${ }^{466}$ Cf. HEIDEGGER, Que Chamamos Pensar? [inédito], p.11.

${ }^{467}$ HERÁCLITO, frag.50, op. cit., p.71.

${ }^{468}$ HEIDEGGER, Heráclito, p. 257.
} 
palavra obediência vem do latim oboedientia. Trata-se da contração da preposição $\mathrm{Ob}$-, indicativa de abertura e acolhida, e audientia, que vem do verbo audire e indica o vigor da escuta. Obediência é ser todo ouvidos no acolhimento. ${ }^{469} \mathrm{O}$ ser todo ouvidos está ligado ao acolher e silenciar de uma escuta obediente. Nessa obediência está o aberto que possibilita a escuta de um toar que reverbera o mais íntimo do homem. A escuta, como um perceber de um ouvir-estar-silente, entranha e embrenha-se em nós trazendo a unidade de um múltiplo. ${ }^{470}$ Heráclito não diz o que é o lógos, mas sabemos, através de uma escuta obediente, que tudo é um. Há na dinâmica de realização do lógos a expressão de uma força de concentração, um poder de reunião. Lógos é a unidade de todas as coisas, é aquilo que tudo reúne, que a tudo recolhe. Nisto consiste a apreensão da totalidade. Heidegger infere que a essência originária do lógos se une àquilo que os primeiros pensadores gregos nomearam de phýsis e alétheia. Nesta coletividade tudo é um, mas não é igual. Há uma unidade, mas não uma uniformidade. Lógos não é phýsis que, por sua vez, não é alétheia, mas ele é o uno que tudo reúne. O lógos é, como diz Heidegger, "a coletividade originária que resguarda e preserva o ente como o ente que é. Esse lógos é o próprio ser que vigora em todo o ente." ${ }^{471}$ Isto significa que, pensado originariamente, o lógos deixa-ser a coisa como coisa, deixa viger o ser em sua própria verdade. O lógos é o resguardo que guarda o verdadeiro, e guardar o verdadeiro significa que se colheu em sentido próprio. O fragmento de Heráclito se dirige aos homens. São eles que devem ouvir o lógos para nesta remissão receber dele a sua própria possibilidade essencial, ou seja, a experiência de ser só se cumpre em uma experiência originária da essência do homem. Este é um modo de ser que só se cumpre no existir do homem. Não se trata de uma existência qualquer, mas aquela totalmente inserida em um processo de integração com a vida - vida que é o próprio movimento de vir à luz. Ânima. Alma. Psyché. Aquilo que faz uma coisa ser a própria coisa, o movimento que move a si mesmo desde si mesmo, de tal forma, que aquilo que aparece é o seu mais próprio, aquilo que se é. Isto é espontaneidade, naturalidade, o brotar e o irromper da vida como vida. Caeiro parece bem entender aquilo que anima cada coisa quando faz suas conjecturas:

Também sei fazer conjeturas.

\footnotetext{
${ }^{469}$ Cf. HARADA, Coisas, velhas e novas, p.183-184.

${ }^{470}$ HEIDEGGER, Sobre a Essência da Linguagem, p.94-95.

${ }^{471}$ HEIDEGGER, op. cit., p. 288.
} 
Há em cada cousa aquilo que ela é que a anima.

Na planta está por fora e é uma ninfa pequena.

No animal é um ser interior longínquo.

No homem é a alma que vive com ele e é já ele.

Nos deuses tem o mesmo tamanho

E o mesmo espaço que o corpo

E é a mesma cousa que o corpo.

Por isso se diz que os deuses nunca morrem.

Por isso os deuses não têm corpo e alma

Mas só corpo e são perfeitos.

O corpo é que lhes é alma

E têm a consciência na própria carne divina. ${ }^{472}$

O poeta infere que cada coisa tem em si aquilo que a anima. Melhor dizendo, aquilo que cada coisa é é aquilo que a anima: na planta é a ninfa pequena que está fora, no animal é um ser interior, no homem é a própria alma que vive com ele e é ele mesmo. Isto significa que em cada coisa encontramos aquilo que a faz ser mais si mesma, mas é somente no homem que vemos a culminância da alma com a própria vida, com sua existência. Podemos, pois, dizer que na escala dos meros viventes existem vários graus de alma, mas é o homem o lugar e a hora do acontecimento da vida como sentido de ser - ser desde si mesmo e a partir de si mesmo. Não está nem fora e nem dentro, diz o poeta, como nas plantas e nos animais, mas "vive com ele e já é sempre ele.” A relação entre homem e alma exposta por Caeiro, define um modo de ser em que a alma já é o próprio homem, é aquilo que o anima e lhe dá vida. Esta é a totalidade do conjunto da experiência humana, vale pra tudo que constitui o modo de viver e realizar-se dos homens. Por certo, não nos referimos aqui ao conceito de animus que na modernidade assumiu o lado sentimental da consciência humana. Muito menos, à compreensão de alma pensada por Aristóteles que, no escrito De Anima, apesar de compreender a alma como causa e princípio do corpo que vive, afirma haver uma relação de continuidade quanto às faculdades da alma dos homens e todos os outros viventes, uma vez que o primeiro possui todas as faculdades presentes nos últimos. Nem mesmo o intelecto o distingue, pois, em alguns seres vivos também encontramos o raciocínio e o intelecto. ${ }^{473} \mathrm{~A}$ compreensão da alma e sua relação com a vida atravessou os tempos e é bastante especulativa. Agrada-nos a compreensão trazida por Erwin Rohde, filólogo alemão, amigo e contemporâneo de Nietzsche, que descreve magistralmente, no livro

\footnotetext{
${ }^{472}$ PESSOA, Obra Poética, p.245-246; idem, Obra Completa de Alberto Caeiro, 119-120.
}

${ }^{473}$ Cf. ARISTÓTELES, De Anima, p.77-79. 
Psyche, os cultos dionisíacos na Frígia e na Trácia de forma a estabelecer as fontes da crença na imortalidade da alma e explorar sua relação com a vida. O filólogo examina de modo bastante acurado como a crença na alma aparece e mostra como a psyché está associada ao corpo já nos poemas de Homero, não como algo adicionado que vive separadamente e depois da morte dissocia-se e desaparece de forma independente. Rohde afirma que Homero usa inequívoca e inúmeras vezes a palavra psyché quando deveria usar vida. Segundo o autor, a troca de um pelo outro não é fortuita, uma vez que a vida e a existência sobre a terra têm uma profunda compreensão para Homero - é para os fortes e prudentes que o mundo homérico é criado. Assim como acabamos de ver com o poema de Caeiro, a psyché para o poeta épico da Grécia antiga permanece uma coisa real, de tal modo que sua forma é a própria imagem do homem. ${ }^{474}$ Tal assunção é reforçada na contemporaneidade por Bruno Snell, em The Discovery of the Mind, quando, em mais de uma ocasião, o autor reafirma a compreensão de que, para Homero, a psyché é a força que mantém a vida ${ }^{475}$ Há, portanto, em Homero, uma relação bastante próxima entre alma e vida. Filosoficamente, é Platão, no Fedro, que desenvolve a compreensão de alma como movimento autônomo quando, a partir da afirmação de que a alma é imortal, desenvolve a argumentação de que a alma move a si própria e neste movimento faz mover o céu e a terra. Ouçamos a bela passagem de Platão, na voz de Sócrates:

Assim então é princípio de movimento o que a si mesmo si move; e isto nem é possível que pereça nem que venha a ser, senão todo o céu e toda a terra confundindo-se parariam e jamais teriam de novo de onde movidos se engendrassem. Imortal então evidenciado o que a si mesmo se move, quem disser que a essência, a noção de alma, é isso mesmo, não se envergonhará. ${ }^{476}$

Na compreensão de alma como movimento autônomo, que move a si mesmo e desde si mesmo por pura gratuidade e sem o qual não haveria nem céu nem terra, ecoa o entendimento de vida e existência como a força geradora que põe o homem a caminho do seu desencobrimento, do seu envio, do seu destino, da própria vida criadora e sobre a qual não há controle. Mesmo sendo uma conquista, há nisso uma entrega e doçura. Sabemos que ele não é o autor disso, mas, na medida em que isso se cumpre, ele precisa ser o pastor, a salvaguarda, o guardador deste rebanho. Isso que o acomete faz uso dele. Faz surgir o poeta. Faz surgir a coisa. O poeta é aquele

\footnotetext{
${ }^{474}$ Cf. ROHDE, Psyche, p.31.

${ }^{475}$ Cf. SNELL, The Discovery of the Mind, p.8 e 198, respectivamente.

${ }^{476}$ PLATÃO, Fedro, p.81.
} 
que deixa-ser, faz-se passagem e deixa a poesia ser. Esta é sempre uma compreensão difícil, uma vez que nosso pensamento se pauta pelo entendimento que, sendo poeta, Pessoa é o sujeito do ato de escrever. Sabemos que Pessoa é cidadão português, poeta, trabalhou como jornalista, editor e foi tradutor de Shakespeare e Edgar Allan Poe para o português. Existe concretamente uma vida atravessada pela cotidianidade. Só que o sujeito Pessoa e tudo o que o perfaz não é primário, primeiro. $\mathrm{O}$ eu que escreve e se coloca como princípio e causa do escrever é tardio, posterior. Desconcertantemente, Pessoa não é a causa de "Mensagem", nem Caeiro de "O guardador de rebanhos", ou Campos de "Tabacaria". Ao contrário, são os poemas a causa de seus poetas. $\mathrm{O}$ escritor não existe antes do escrever. Nada é dele, mas tudo é ele! Por outro lado, isso não significa que não há labuta, não há trabalho. Edgar Allan Poe, no ensaio intitulado A Filosofia da Composição, refaz de modo bastante consistente o passo-a-passo da construção de seu célebre poema "O Corvo", magistralmente traduzido para o português por Fernando Pessoa. Poe nega que algo de sua composição seja atribuído a algum acidente ou intuição, mas é realizado com "a precisão e a sequencia rígida de um problema matemático. ${ }^{477}$ Fazemos notar a exacerbada, porém rara, compreensão por parte de um poeta para a árdua labuta empreendida no processo de composição de um poema por entendermos que há, sim, um trabalho bastante relevante e que deve ser destacado. O poeta não recebe a palavra por osmose. Ela não cai do céu! A lida com a palavra é árdua. Se tomarmos por base os escritos de Pessoa, vemos nos caderninhos, nos bloquinhos de anotação, nas milhares de folhas soltas que compõem o espólio do poeta português, exposto no acervo da Biblioteca Nacional de Portugal, os rabiscos, acréscimos, dúvidas e nomes a quem os poemas podem ser atribuídos, enfim, vemos claramente o processo pelo qual o poema passa. Porém, isso não invalida o que acabávamos de dizer: é pelo ato de escrever que Pessoa se faz escritor e se torna quem ele é. O que advém daí é o despertar para uma dimensão própria da existência humana que é a de se entregar à saga do dizer - ou ao dizer que se entrega à saga, pois, "entrar na verdadeira saga caracteriza um dizer que segue o caminho daquilo que necessita ser dito com a única finalidade de o dizer." "478 Tal caminho é o da linguagem - lugar da casa do ser, lugar de habitação das raízes do homem. Isto é autorrealização. É cura. É ser na totalidade. É salvação.

\footnotetext{
${ }^{477}$ POE, "A filosofia da composição", in:

${ }^{478}$ HEIDEGGER, "Para quê poetas?, in: , “O Corvo" e suas traduções, p.48. Caminhos de Floresta, p.362.
} 
É a celebração do sagrado. ${ }^{479}$ Entretanto, para isso, é preciso que os deuses inflamem a alma do poeta como um raio de luz. António Mora, no prefácio à obra de Alberto Caeiro, escreve:

[...] Que gesto inicial dos Deuses obrou esse milagre humano? Como foi que um português, nascido na extrema desordem da Europa, na última abjeção da pátria encontra em si a substância íntima daquela verdade por que os gregos conquistaram o mundo? Não sei explicar, nem é preciso, aceito o facto por o que os Deuses o quiseram. ${ }^{480}$

Os deuses o quiseram, diz Mora sobre o mestre. Trata-se da possibilidade de ser tocado pela transcendência e do abrir-se a um outro modo de ser que irrevogavelmente se impõe, tal como nos descreve Fogel, em Sentir, Ver, Dizer:

Um deus, um deus grego, tal como são os deuses para Caeiro, pois Caeiro é grego - um deus grego, portanto, fala da experiência, quer dizer, do fenômeno ou o acontecimento do homem ser tocado e tomado pelo abrir-se e inaugurar-se de um âmbito ou de um domínio possível de realidade, que assim e por isso se mostra e evidencia como que definitiva e irrevogavelmente, e que ultrapassa, transcende ao homem, à sua vontade, ao seu querer ou ao seu poder de decisão, mas em cujo âmbito e vigência de sentido, o homem pela experiência, a partir dela e graças a ela, não pode abrir mão, não pode não mais estar ou ser. Um deus, assim, é absolutamente necessário. Isto, a saber, tal abrir-se, dar-se, impor-se, é divino, é sagrado. ${ }^{481}$

Não pode não ser! Uma vez atingido em pura doação e gratuidade pelo raio da alteridade divina, o poeta, transpassado por essa transcendência, é tomado pelo sagrado. Nesta abertura a palavra poética emerge e faz aparecer o copertencimento entre homens e deuses. ${ }^{482}$ Referimo-nos ao levantamento de medida que mede o entre e faz céu e terra caminharem um em direção ao outro. ${ }^{483} \mathrm{O}$ copertencimento entre homens e deuses é a justa medida para a poesia. Nisso não há método, não há régua e compasso, mas, uma cadência própria onde o desconhecido revela-se como desconhecido e dá a medida para a essência do poeta. Há nisto um pertencimento mútuo. ${ }^{484}$ Este é o habitar pleno, em seu aspecto fundamental, pois deixa ver aquilo que é possível ver, a saber, o sentido do que é resguardado no encobrimento: a

\footnotetext{
${ }^{479}$ Heidegger usa o termo Heile para falar da cura do aberto que, segundo o tradutor, possui a mesma raiz que das Heilige, santo ou sagrado. Lembremos da nota, ao final de nosso segundo capítulo, quando nos referimos ao fato de que os termos contêm uma gama de sentidos muito ampla, a qual abrange as noções de salvação e graça.

${ }^{480}$ MORA, "Prefácio à obra de Alberto Caeiro", in: PESSOA, O Regresso dos Deuses, p.103.

${ }^{481}$ FOGEL, Sentir, Ver, Dizer, p.119.

${ }^{482}$ Cf. HEIDEGGER, Explicações da Poesia de Hölderlin, p.83.

${ }^{483}$ Cf. HEIDEGGER, “...poeticamente o homem habita...”, in: p.172.

${ }^{484}$ Cf. Ibidem, p. 174 . , Ensaios e Conferências,
} 
verdade do ser. A medida que mede com inteireza não tenta arrancar o que se encobre do seu encobrimento. Isto, como vimos, não é possível. Nesse deixar ver o que se encobre, há um resguardar-se do que se encobre. É constitutivo do ser o retraimento. Todavia, há uma correspondência que se estabelece a partir desta abertura, desta espera e escuta, pois, "tudo vem a ser conforme e de acordo com esse lógos. ${ }^{485} \mathrm{O}$ poeta é, pois, aquele que vislumbra o traço fundamental dessa abertura e desagua essa medida no habitar humano, e é a poesia que permite ao habitar ser um habitar em sentido próprio. Por outras palavras: A fala do poeta é a escuta a um apelo, a resposta a um chamado e, por isso, é a saga do dizer que fala no seu elemento mais próprio. O poeta é aquele que vê o vigor e a essencialidade desse habitar e sua fala se dá a partir e desde essa experiência tão própria de linguagem - lugar em que a linguagem fala.

São os deuses que, segundo Mora, são os verdadeiros artistas das coisas reais ${ }^{486}$, sendo que "a raça dos deuses e dos homens é uma só." ${ }^{887}$ Ricardo Reis assim escreve, em 1914:

[...] Só os deuses socorrem

Com seu exemplo aqueles

Que nada mais pretendem

Que ir no rio das coisas. ${ }^{488}$

A singeleza do canto nos fala do amparo dos deuses àqueles que nada mais querem do que a simplicidade das coisas, da vida. Caeiro é desses. É Caeiro que "em vinte séculos de nevoa, deixou ver o contorno dos montes, e a realidade direta das pedras e das flores [...]." ${ }^{489}$ Longe do ruído da civilização, a obra de Caeiro frui na transitoriedade da vida a reverberação da eternidade dos deuses. Ele é aquele a quem os deuses consentiram a visão da verdade das coisas em sua irremediável realidade, desde e nelas mesmas. Segundo Reis, Caeiro tem a lucidez do espírito e não se deixa levar pelas "saturnálias do humanitarismo e da vida moderna." ${ }^{490}$ Ele

\footnotetext{
485 HERÁCLITO, frag. 1, in: Os Pensadores Originários: Anaximandro, Parmênides, Heráclito, p.59.

${ }^{486}$ Cf. MORA, “O regresso dos deuses”, in: PESSOA, O Regresso dos Deuses, p.42.

${ }^{487}$ Ibidem, p. 170.

488 PESSOA, Obra Poética, p.267; idem, Obra Completa de Ricardo Reis, p.67.

489 PESSOA, Obras em Prosa, p. 122.

${ }^{490}$ Ibidem, p.114. A palavra saturnália refere-se na mitologia às comemorações do deus Saturno, na Itália. As festas seriam uma forma de celebrar a antiga idade de ouro, uma espécie de estado paradisíaco, "quando a terra tudo produzia abundantemente, sem trabalho", de modo a obter graças e proteção do deus de Saturno sobre a plantação. O termo argonauta também se refere à mitologia e diz respeito aos lendários heróis gregos que buscavam o tosão de ouro nas expedições a bordo da
} 
é o grande revelador da realidade, o "Argonauta das sensações verdadeiras" aquele que nos restituiu a simplicidade das coisas mesmas. Para Reis, Caeiro é o deus dos bosques, dos campos, das montanhas, dos rebanhos e pastos - o grande Pã! ${ }^{492}$

Heidegger diz que a palavra do poeta vela o sagrado - o poetar é o poetar do sagrado. ${ }^{493}$ Há nisso uma relação com o divino. ${ }^{494}$ Diante do colapso do mundo sagrado medieval e do "deserto industrial e utilitário erigido pela civilização racionalista," ${ }_{495}$ Novalis, já no final do sec. XVIII, afirmava que "a poesia é a religião natural do homem." ${ }^{496}$ Não que esta religião estivesse vinculada a uma determinada crença ou a um deus. Trata-se mesmo da relação do poeta com o divino. Schlegel, em seus manuscritos sobre poesia, refere-se ao caráter elevado da história como a hora e o lugar da síntese da divindade com o homem. ${ }^{497}$ Octavio Paz, se refere a "um novo sagrado, fora de toda igreja e fideísmo" ${ }^{498}$. Através dos séculos, são inúmeros os relatos sobre esta conexão. Não se trata de nada novo. Os grandes mitos e os grandes poetas foram considerados a senda para o divino. Esta é uma compreensão que remonta o início da tradição filosófica. Busquemos algum amparo em Platão.

Em Íon, um diálogo da juventude, o filósofo grego também associará a poesia ao divino e os poetas aos intérpretes dos deuses. Ouçamos a voz de Sócrates, no diálogo com Íon, quando ao se referir ao poema, diz:

Nele, portanto, definitivamente, o deus nos mostra, para que não duvidemos, que não são humanos estes belos poemas, nem de homens, mas divinos e de deuses, e os poetas não são nada além de intérpretes dos deuses, possuídos por aquele que possui cada um..$^{499}$

Um outro momento em que Platão relaciona os poetas ao divino, encontra-se em Mênon, considerado um diálogo de transição. Ali, o mesmo Sócrates, ao se referir aos poetas, diz: "Logo, chamaríamos corretamente divinos tanto aqueles que ainda

nau Argo, construída com a ajuda da deusa Atena. (Cf. BRANDÃO, Mitologia Grega, vol. 1, p.340342).

491 PESSOA, Obras em Prosa, p.116.

492 Cf. Ibidem, loc. cit.

${ }^{493}$ Cf. HEIDEGGER, O Acontecimento Apropriativo, p.304.

${ }^{494}$ Cf. HEIDEGGER, "Para que poetas?", in: Caminhos de Floresta, p.366.

495 PAZ, A Busca do Presente, p.64.

496 NOVALIS apud PAZ, idem, loc. cit.

${ }^{497}$ Cf. SCHLEGEL, Fragmentos sobre Poesia e Literatura, p. 404.

${ }^{498}$ PAZ, op. cit., loc. cit.

${ }^{499}$ PLATÃO, Íon, p. 41. 
agora mencionamos, pronunciadores de oráculos e adivinhos inspirados, quanto todos, sem exceção do gênero poético. ${ }^{" 500}$ A partir dos trechos citados, vemos com clareza que, neste período do pensamento platônico, os poetas são considerados intérpretes dos deuses e seus poemas divinos. Sabemos, entretanto, que este não será o posicionamento do pensador grego ao longo de sua vida. É notória a ambiguidade a respeito da poesia no livro X, de $A$ República, onde Platão chega a expulsar os poetas da pólis. Nesta fase de seus escritos, o filósofo entende a poesia como mímesis, a arte da imitação, e esta poderia comprometer a ética na medida em que representa algo que muitas vezes não está associado ao conhecimento do bem e do belo. Ainda que, em seu escrito tardio, Platão se afaste da poesia, Heidegger assim justifica a importância do tema em relação ao pensamento platônico. Ele diz:

o fato de a poíessis como "poesia" ter se tornado principalmente o nome para a arte da palavra, a arte poética, é uma prova da posição privilegiada dessa arte no interior da arte grega como um todo. Por isso, é tão pouco acidental que Platão, ao dar voz e levar até uma decisão a relação entre arte e verdade, trate primeiramente, e de maneira preponderante, da arte poética e dos poetas. ${ }^{501}$

O trecho fala de uma posição privilegiada da poética da palavra que aflora na relação entre arte e verdade no pensamento platônico. Vejamos, grosso modo, de que forma o pensador alemão entende esta relação: na medida em que para Platão o ser é visível nas ideias e estas são o verdadeiro ente, deve haver uma relação entre arte e verdade, uma vez que toda arte está relacionada a um saber e este a uma participação no ente. Sendo, então, a poíêsis a forma mais elevada da arte, ela também está relacionada à verdade, ao desvelamento do ente. Por isso, devemos nos afastar de todas as concepções prévias sobre a mímesis, tais como cópia, representação ou imitação de algo que já está dado, e devemos nos aproximar da compreensão grega de posicionamento e participação diante do ente que se mostra a partir e desde si mesmo. Só assim poderemos entender que o que fundamenta a mímesis não é senão a relação com ente enquanto tal. Heidegger entende que a compreensão de alétheia, desvelamento, é o solo sob o qual a mímesis se posiciona e só assim ela deve ser entendida. ${ }^{502}$ Caminhemos um pouco mais.

Também em Aristóteles, vamos encontrar a mímesis como parte da arte poética. Entretanto, ao contrário de Platão, para o Estagirita, esta é entendida como

\footnotetext{
${ }^{500}$ PLATÃO, Mênon, p.109.

${ }^{501}$ HEIDEGGER, Nietzsche I, p.149.

${ }^{502}$ Cf. Ibidem, p. 153 .
} 
um procedimento artístico pura e simplesmente. ${ }^{503}$ Além disso, a mímesis é uma ação natural do homem e sua primeira forma de conhecimento. ${ }^{504}$ Está, pois, inscrita na natureza do homem a capacidade mimética, a qual está sempre associada à produção de um saber. Quando se trata da poiétiké aristotélica, Heidegger entende que há uma profunda significância nas palavras "tão pouco pensadas de Aristóteles" quando este afirma que "poetizar é mais verdadeiro que investigar o ente." nesta afirmação a compreensão de que a poesia é um acontecimento de verdade, de desvelamento, um acontecimento em que a palavra é fundadora de realidade à medida em que traz à luz, ilumina, torna a coisa visível. Há na poesia um fazer mais elevado, um dizer-aparecer - um dizer que traz para um aparecer e nisso instaura o ente como ente. É a palavra que confere vigência. É a palavra que instaura o ser, na medida em que o ente aparece. ${ }^{506} \mathrm{O}$ pensador alemão também nos lembra que desde Aristóteles esse dizer é considerado lógos apophantikòs, um dizer que mostra, que retira o ente do velamento. ${ }^{507}$ É neste sentido que a mímesis será entendida como a faculdade de tornar-presente, não no sentido de uma cópia, de uma reprodução, mas, como nos diz Lacoue-Labarthe, no de "tornar-presente o que necessita ser presentificado, quer dizer, o que, sem isso, não se teria tornado presente como tal [...]." ${ }^{508}$ Segundo o filósofo francês, poíesis, téchnē e mímesis estariam elevadamente juntas no fazer poético, sendo a última "a condição da possibilidade do saber de que há o ente (e não nada)" "509, e o lógos apophantikòs, "o dizer do aparecimento ou da pura epifania, uma vez que é a própria luz que aparece como aquilo a partir do qual todo visível se apresenta." ${ }^{510}$

Ainda que não seja nossa intenção aprofundar o pensamento de Platão ou de Aristóteles ${ }^{511}$, entendemos que em ambos os casos, ainda que de modos distintos, ficam evidenciadas a sacralidade do ato de pronunciar a palavra poética e a relevância da poesia na tradição grega do pensamento. Lacoue-Labarthe, encerra

\footnotetext{
${ }^{503}$ Cf. PINHEIRO, “Introdução”, in: ARISTÓTELES, Poética, p.7-19.

${ }^{504}$ ARISTÓTELES, idem, p.57.

${ }^{505}$ ARISTÓTELES apud HEIDEGGER, Sobre o Humanismo, p.97.

${ }^{506}$ Cf. HEIDEGGER, “A Palavra”, in: ___ A Caminho da Linguagem, p.180.

${ }^{507}$ HEIDEGGER, Ser e Tempo, p.71-72.

${ }^{508}$ LACOUE-LABARTHE, A Imitação dos Modernos, p.258. Itálico do autor.

${ }^{509}$ Ibidem, loc. cit. Itálico do autor.

510 Ibidem, p.264.

511 Para uma análise aprofundada sobre a poesia, ver a excelente introdução de Cláudio Oliveira ao Íon, de Platão (Cf. PLATÃO, Íon, p.11-22), e a introdução de Paulo Pinheiro à Poética, de Aristóteles (Cf. ARISTÓTELES, Poética, p.7-31).
} 
seu escrito com uma belíssima citação de Walter Benjamin, a qual não nos furtaremos em reproduzir. Benjamin diz: [...] tanto quanto Deus consinta, somente a natureza guarda seu segredo. A verdade se desvela na essência da linguagem. Quando o corpo humano é desnudado, é sinal que o próprio homem comparece diante de Deus." ${ }^{512}$ São, pois, os poetas que desnudados comparecem diante dos deuses e seguem seus vestígios para anunciar em seus cantos o próprio ser, cujo destino é o de estar-revelado no dizer poético. ${ }^{513}$ São eles que testemunham a presença das coisas e na lida com a palavra deixam dizer aquilo que a palavra em sua essência diz. São eles que se lançam à escuta do inaudito, do inefável, de modo que seu canto repercuta como palavra de cura para o mundo ao cantar o são no insão. ${ }^{514} \mathrm{O}$ porvir da palavra anunciadora é desencobridora. Ela proclama a cura para a existência mundana.

António Mora também reconhece em Caeiro a cura para o mundo doente. Ele saúda a vida do mestre como um prenúncio do regresso dos deuses quando diz: "Alegrai-vos, todos vós que chorais, sem saber porquê, na maior doença das civilizações. O Grande Pã renasceu!" ${ }^{15}$ Em realidade, Caeiro é considerado a cura para o homem que, vassalo do pragmatismo utilitário cientificista manifesto em todas as esferas da vida humana, perdeu-se de si mesmo e abdicou da capacidade de pensar. Antagonista das gerações anteriores impregnadas do espírito religioso profundo, a massa humana moveu-se em direção à ciência como uma válvula de escape. Todavia, a repulsa à primeira não impediu a decadência do início do século $\mathrm{XX}$, como bem vimos em nosso segundo capítulo. Cego para a possibilidade de ver a impessoalidade que o conduz no mundo, Mora entende que era preciso um Caeiro para mostrar ao homem doente de seu tempo exatamente aquilo que ele não enxergava. O poeta do tempo indigente tem que poetar a essência da própria poesia. ${ }^{516} \mathrm{O}$ pensamento poético de Caeiro habita neste domínio. Diz Mora, no prefácio à obra do mestre:

Quem ler o que ele escreveu, e o compreender, quando erguer os olhos do livro encontrará um novo mundo. Que digo? Um novo mundo, não: O mundo mais antigo de todos - o mundo real tal qual os deuses no-lo deram, a face primeva e constante da terra verdadeira, das cousas reais e dos homens na sua naturalidade.

\footnotetext{
512 BENJAMIN apud LACOUE-LABARTHE, A Imitação dos Modernos, p.267.

${ }^{513}$ Cf. HEIDEGGER, "Para quê poetas?", in:

${ }^{514}$ Cf. Ibidem, p.365.

${ }^{515}$ MORA, “O regresso dos deuses", in: PESSOA, O Regresso dos Deuses, p.97

${ }^{516}$ Cf. HEIDEGGER, op. cit., p.312-313.
} 
Quem ler esta obra e não lhe errar o sentido, não mais poderá duvidar da certeza externa das cousas, que o spiritualismo de nossos maiores velou e o criticismo dos nossos pais esqueceu. [...] Como no alto das montanhas o ar é diverso, e a paisagem outra, aqui é a mente mais pura e o spírito mais vasto e repousado. Aqui a febre dos nossos sonhos cristãos se acalma, e se cura a doença das nossas ambições estéreis e das nossas agitações inconsumíveis. Obra digna, decerto, do amor dos deuses, esta, que, sem falar neles, não é senão o sentido do seu culto. [...] Esta obra é um repouso e um livramento, um refúgio e uma libertação. ${ }^{517}$

Trata-se, como vemos, da exaltação da palavra como gênese do mundo como mundo, do mundo real, tal como os deuses nos deram. Caeiro é este que anuncia um novo tempo, que traz um alento para a estéril opressão da vida. Em sua desconcertante simplicidade, o mestre de todos é cura para o espírito secular cientificista, cuja fria e objetivada fé metodológica não foi suficiente para aplacar a subjetividade e sentimentalismo deixados em gerações impregnadas por um fundo moral religioso. A falta de Deus não só significa que não há um Deus a articular a história do mundo, mas, sobretudo, anuncia a ausência da divindade e a perda do sagrado. ${ }^{518}$ A horda humana desta era do mundo se encontra à deriva de um pertencimento, flutua num oceano de incertezas sobre o seu destino. Nem lá nem cá. Um tempo indigente e decadente, como vimos anteriormente. Mora conta que na aurora grega havia o reino da Coisa. De um lado, existia a Coisa e do outro, em bloco, a sensação imediata, vivida. Nisso, a Coisa surgia perfeita e nítida na realização. As sensações eram concretas e bem definidas, não havia penumbra na alma dos gregos. Tudo se destacava em plena luz. A sensação era direta, imediata. Não se interpunha nenhuma reflexão ou qualquer outro elemento ao ato de sentir. Ele diz: "A atenção era por isso perfeita, cingia cada objeto por sua vez, delineavalhe os contornos, recortava-o para a memória." ${ }_{519}$ Tudo era concretizado por uma acuidade equilibrada da visão. $\mathrm{O}$ advento da religião criou uma doença na alma do homem e perturbou a clareza da sensação. O pensamento infestado por ideias de espírito, Deus, vida além da vida, deturparam a realidade, assim como havia sido pensada pelos gregos. Entre a sensação e o objeto "intercalara-se todo um mundo de noções espirituais que desvirtuava a visão directa e lúcida das cousas." ${ }_{520}$ A própria noção de Deus se transfigurou. $\mathrm{O}$ que antes era concebido como mero

\footnotetext{
${ }^{517}$ MORA, "Prefácio à obra de Alberto Caeiro", in: PESSOA, O Regresso dos Deuses, p.107.

${ }^{518}$ Cf. HEIDEGGER, "Para quê poetas?", in: __ Caminhos de Floresta, p.309.

519 MORA, "Prolegómenos a uma reforma do paganismo, in: PESSOA, O Regresso dos Deuses, p.149.

${ }_{520}$ Ibidem, loc. cit.
} 
prolongamento da humanidade tornou-se contrário ao homem. O divino, o invisível, o ultra-humano opôs-se à realidade humana. A noção de Deus apartou-se da Natureza. A própria noção de alma, entendida como separada e superior ao corpo, tornou as coisas do espírito mais importantes do que as coisas do mundo. Tudo isso enfraqueceu a atenção, perturbou a visão do homem. Desta escuridão ergue-se a voz de Caeiro a cantar o sagrado das coisas simples. Sua obra, por certo, é digna do amor dos deuses. Apesar de não falar neles, este "não é senão o sentido do seu culto" 521 , diz Mora. Tomado pela sensibilidade pagã, ao nomear as coisas, ao chamá-las pelo nome, o poeta apresenta ao mundo o sagrado que há na Natureza. Basta sorver seus poemas para que o ar das montanhas preencha o ruído da vida e tudo se torne sol e flor e campo. Ouçamos o restante do belíssimo poema $\mathrm{V}$, de " $\mathrm{O}$ guardador de rebanhos", iniciado em nosso capítulo anterior:

[...] Não acredito em Deus porque nunca o vi.

Se ele quisesse que eu acreditasse nele,

Sem dúvida que viria falar comigo

E entraria pela minha porta dentro

Dizendo-me, Aqui estou!

(Isto é talvez ridículo aos ouvidos

De quem, por não saber o que é olhar para as coisas,

Não compreende quem fala delas

Com o modo de falar que reparar para elas ensina.)

Mas se Deus é as flores e as árvores

E os montes e sol e o luar,

Então acredito nele,

Então acredito nele a toda a hora,

E a minha vida é toda uma oração e uma missa,

E uma comunhão com os olhos e pelos ouvidos.

Mas se Deus é as árvores e as flores

E os montes e o luar e o sol,

Para que lhe chamo eu Deus?

Chamo-lhe flores e árvores e montes e sol e luar;

Porque, se ele se fez, para eu o ver,

Sol e luar e flores e árvores e montes,

Se ele me aparece como sendo árvores e montes

E luar e sol e flores,

É que ele quer que eu o conheça

Como árvores e montes e flores e luar e sol.

E por isso eu obedeço-lhe,

(Que mais sei eu de Deus que Deus de si próprio?),

Obedeço-lhe a viver, espontaneamente,

Como quem abre os olhos e vê,

E chamo-lhe luar e sol e flores e árvores e montes,

${ }^{521}$ MORA, "Prefácio à obra de Alberto Caeiro", in: PESSOA, op. cit., p.107. 
E amo-o sem pensar nele,

E penso-o vendo e ouvindo,

E ando com ele a toda a hora. ${ }^{522}$

À parte de toda a questão do ver e do ouvir aqui presentes, fazemos notar a face amiga da Natureza em seu estado primevo, o gozo da contemplação que torna sagrada a mais simples comunhão com as coisas e a compreensão de seguir e obedecer ao Deus da vida que brota em cada flor, que nasce em cada rio, que habita em cada monte. Através dessa comunhão com a natureza, Caeiro resgata o caráter experiencial e opõe-se à busca de um fundamento único e definitivo para a vida. A obediência que aqui se impõe é o afinamento com a abertura, com a própria medida que vincula à possibilidade, ao poder-ser de realidade aparecer enquanto e como dizer. Caeiro é o testemunho desse acontecimento e celebração de verdade - um acontecimento de pura gratuidade que o atravessa, o transcende e restaura a experiência de mistério na fala e no discurso. É sobre isso que falávamos no início - há uma sacralidade neste nomear do poeta que mostra a coisa como que pela primeira vez. Ao nomear o luar, o sol, as flores, as árvores e os montes a palavra cria. Ela é princípio de realidade. Palavra e ação geram vida, e vida plena de sentido. Aqui a linguagem fala e o poeta é o porta-voz da vida. Ele obra a própria obra divina que se impõe sobre ele. Ele não pode não ser assim. Nesta abertura, vida é mando - obediência - acolhimento. O poeta ouve e acolhe rendendo-se ao que é maior e esse maior faz uso dele. Este é exato momento em que o poeta é poeta. $\mathrm{O}$ momento em que ele desperta para o modo de ser que faz com que ele seja mais ele mesmo, que faz com que ele esteja no seu envio, no destino de ser no sentido e na determinação do ver e do ouvir, que, como vimos, em nada se relacionam com o sentidos sensoriais uma vez que não tem base ou fundamento no sensível. Referimo-nos unicamente ao ver que Heidegger nomeou de percepção - percipere - noûs. Só que para isso, o homem precisa se colocar nessa dimensão. Ele precisa dar um salto! Um salto que instaura um outro modo de ser do homem, no qual o pensamento consuma no dizer o testemunho da visão que viu o ver. É somente quando o homem se eleva e se mantém nesta abertura que a história começa. ${ }^{523} \mathrm{~A}$ essência de toda a história é determinada por este destinar, por este envio. Isto significa que a história não é apenas o exercício da atividade humana e, nem

\footnotetext{
522 PESSOA, Obra Poética, p.206-208; idem, Obra Completa de Alberto Caeiro, p.37-39.
}

${ }^{523}$ Cf. HEIDEGGER, "Sobre a essência da verdade", in: Os Pensadores, p.162. 
tampouco, um simples produto historiográfico ${ }^{524}$, cujo desenrolar dos fatos de processa ao longo do tempo. Não! História é a irrupção no homem de um modo de ser que é desocultação, alétheia. A história, diz Heidegger, "indica a constituição de ser do 'acontecer', próprio da presença enquanto tal." ${ }^{525} \mathrm{O}$ pensador estabelece aqui uma relação entre o histórico e o acontecimento apropriador para designar a abertura de sentido de ser dentro de uma temporalidade toda própria. Há, pois, um nexo entre a história e este acontecimento. Voltemo-nos para isto.

\subsection{O tempo da história ou a história do tempo da poesia}

Na última parte de Ser e Tempo, considerada pelo próprio Heidegger como a preparação de um caminho para a questão existencial da historicidade, o filósofo se reporta à relação entre historicidade e acontecimento mais de uma vez, quando diz que "liberar a estrutura do acontecer e suas condições existenciais e temporais de possibilidade significa conquistar uma compreensão ontológica da historicidade" ${ }_{526}$, ou, quando afirma que "história é o acontecer específico da presença existente que se dá no tempo." ${ }^{527}$ Isto significa, em outras palavras, o vir a ser do homem em total plenitude com aquilo que ele tem de mais próprio - o vigorar da abertura que se faz no obrar do homem, dentro de um tempo originário. Só o homem pode ser tocado e tomado por este acontecimento. Quando isso se dá, o destino irrompe e vai se forjando, vai se cunhando. O tempo aqui não é o chronós que flui no tic-tac do relógio, mas, antes, o kairós do instante oportuno da concreção de um destino. "Tempo aqui é vigência, percussão, o ritmo e vibração, a presença plena da atuação" 528 , diz Harada. Este é o tempo em que a (a)ventura de viver se consuma na vigência de um viver pleno, cocriadora de mundo - o momento do encontro da existência do homem com o tempo da história. Entretanto, este é um tempo que não existe em si. É imprevisível, incontrolável. É um tempo que emerge do âmago da vida e salta para uma nova possibilidade de ser, para um envio que conforme avança mais presentifica o sentido da totalidade. No entanto, este tempo

\footnotetext{
${ }^{524}$ HEIDEGGER, “A questão da técnica”, in:

525 HEIDEGGER, Ser e Tempo, p.57.

526 Ibidem, p.466.

${ }^{527}$ Ibidem, p.471.

${ }^{528}$ HARADA, Coisas, velhas e novas, p.415. ,Ensaios e Conferências, p. 27.
} 
não diz respeito apenas ao porvir do homem, mas possui uma relação com o vigor de ter sido que, assume por assim dizer, o papel de uma retomada que se atualiza no instante atual e remete para o porvir. Esta compreensão de tempo, sua estrutura ontológica, Heidegger vai buscar em Santo Agostinho, no livro II, das Confissões, lugar em que a noção clássica de tempo como um processo incontável de sucessões de momentos e movimentos é questionado. De acordo com Pegoraro, Agostinho percebe, ao examinar a interioridade do tempo, que não temos nem passado e nem futuro, mas apenas aquilo que está presentificado na alma. Diz Agostinho: "É claro e manifesto que não existem coisas passadas e futuras, nem se pode dizer com exatidão, que os tempos são três: presente, passado e futuro. [...] Essas três coisas existem na alma e, em outro lugar, não as vejo." ${ }^{529}$ Isto significa que o passado está vivo em nós hoje, assim como o futuro é a antecipação da vida porvir. Ambos se presentificam na vida, no instante presente. Pegoraro entende que as estruturas ontológicas de temporalização coincidem: para Agostinho, a alma é o tempo, e, para Heidegger, a estrutura radical do homem é temporal. Não há para nenhum dos dois uma compreensão de tempo fora do homem. A temporalidade é a dimensão mais radical que o atravessa e é parte integrante de sua estrutura fundamental como serno-mundo. "Nós não estamos no tempo", conclui Pegoraro, "mas somos tempo e processo de temporalização." ${ }^{530}$ A questão do tempo, inicialmente concebida por Agostinho, será ampliada por Heidegger, quando este atrela a noção de tempo à noção de história, destino, envio. Para Heidegger, o vigor do passado determina o tempo histórico presente e temporaliza originariamente o futuro. ${ }^{531}$ Isto significa que "somente este ente, transmitindo para si mesmo a possibilidade herdada, pode assumir o seu próprio estar lançado e ser no modo do instante para o 'seu tempo'." ${ }_{532}$ Este modo do instante não implica o abandono do futuro ou do passado, bem sabemos que os três tempos se encontram no presente. ${ }^{533}$ No entanto, este é um instante inapreensível. Este é o lugar em que todas as dimensões do tempo estão inseridas na história, em sua dimensão essencial - o ter-sido, o instante atual e o porvir diretamente ligados ao acontecimento que faz crescer no homem uma

\footnotetext{
529 AGOSTINHO apud PEGORARO, "Ser e Tempo", in: BERARDINELLI et alii, Fernando Pessoa e Martin Heidegger: O Poetar Pensante, p.30-31.

${ }^{530}$ PEGORARO, idem, p.28.

${ }^{531}$ Cf. HEIDEGGER, Ser e Tempo, p.473.

532 Ibidem, p.477. Grifo do autor.

${ }^{53}$ Cf. PAZ, A Busca do Presente, p. 90.
} 
compreensão transformadora e plena do modo de ser homem. Na conferência “Tempo e Ser, proferida em 1962, Heidegger diz:

"No destinar do destino do ser, no alcançar do tempo, mostra-se um apropriar-se trans-propriar-se, do ser como presença e do tempo como âmbito do aberto, no interior daquilo que lhes é próprio. Aquilo que determina a ambos, tempo e ser, o lugar que lhes é próprio, denominamos: das Ereignis. ${ }^{534}$

O destinar do destino do ser é um acontecimento que se dá única e tão somente nesta dinâmica de temporalização que é a existência humana. Segundo Fogel, em Sobre Homem e História, trata-se de uma estrutura temporal que acontece no âmbito vital chamado instante, o qual se constitui pela simultaneidade das ekstases temporais passado-presente-futuro. Há no instante um campo de presença onde a presença do passado e a presença do futuro vêm ao presente de modo irrevogável. Só que o que vem à presença, tanto do passado quanto do futuro, vem enquanto e como ausência, ou seja, o passado e o futuro são presenças de ausência (memória e espera) a determinar a existência histórica do homem. ${ }^{535}$ Ser, viver, existir é ser no modo de ser que é desvelamento, mas trata-se de um campo de presença que é permeado de ausência. Esta dimensão da existência humana dá-se, acontece, apropria-se do homem que é afetável, tocável. Não se trata de um acontecimento constatável, mas de uma dimensão da vida. O Ereignis é a própria abertura da possibilidade de ser, do autoultrapassamento, da autossuperação - o próprio despertar do homem para o homem. Essa abertura eclode sem porquê ou para quê e libera o homem para o si-próprio, para a liberdade de ser sempre no sentido de ser, de ser na compreensão de ser. Este modo de ser é tempo se fazendo tempo, é realização de história. História, diz Fogel, "é o nome da vida enquanto e como tempo - melhor: é o nome da temporização do tempo no e como viver, existir." ${ }^{336}$ Isto significa que na existência, na vida, o homem desperta para uma tal possibilidade de ser que não é evolução, não é progresso, é retomada, vigor, vida plena. É vida se fazendo maximamente vida: um acontecimento extraordinário da possibilidade de ser que irrompe, aparece subitamente como um salto que determina um tal modo de ser que é o obrar de um destino. Aqui o homem

não possui a liberdade como propriedade, mas antes, pelo contrário: a liberdade, $o$ ser-aí, ek-sistente e desvelador, possui o homem, e isto, tão originariamente que somente ela permita a uma humanidade, inaugurar a relação com o ente em sua

\footnotetext{
${ }^{534}$ HEIDEGGER, “Tempo e Ser”, in:

${ }^{535}$ Cf. FOGEL, Sobre Homem e História, p.61.

${ }^{536}$ Ibidem, p.60. Os Pensadores, p.264.
} 
totalidade e enquanto tal, sobre o qual se funda e esboça toda a história. Somente o homem ek-sistente é historial. ${ }^{537}$

É, pois, a vida que conduz o homem e não o contrário. Não é o homem que possui a liberdade, é a liberdade que o possui e conduz. Neste processo de conquista de si mesmo, o homem é entrega, é escuta, é acolhimento à dimensão de transcendência. Como vimos, isso não é deliberação da vontade do homem, nem tampouco esta relação com o ente em sua totalidade pode ser compreendida como vivência, estado da alma - algo de uma natureza subjetiva. Trata-se de uma experiência de ser no sentido de ser, que no caso do poeta é a relação com a própria dimensão da palavra como poética, da poíêsis como um fazer; o lugar em que a palavra é a própria realização de realidade, movimento de realização do dar-se e do fazer-se de sentido; um dizer que mostra a dimensão do real no seu todo, sem controle ou domínio, e que, no mesmo ato, é linguagem. Isto concretiza o que vínhamos tentando expressar a partir do lógos. Antes do irromper da linguagem poética, há algo que se põe para o homem que determina tanto a visão do ver quanto a irrupção da linguagem como um único e mesmo acontecimento. Há, portanto, uma relação do noûs com o lógos que deve ser traduzida para que a linguagem seja originária. Referimo-nos àquilo que Heidegger chamou de "a relação de todas as relações." ${ }_{338}$ Tratemos, por fim, de alguma forma explicitar essa relação.

É na forma verbal do nô̂s - noeîn - que se consuma a relação do ser com a essência do homem. Entretanto, não é o noeîn que realiza e executa essa relação, é ele que a concede ao ser, sendo esta uma tarefa a ele confiada pelo próprio ser, pois é através do noeîn que o ser tem acesso à linguagem. Referimo-nos à relação essencial de pertença mútua entre a formas verbais do lógos - légein e do noûs noeîn, não apenas como dizer e pensar, mas naquilo que originariamente nomeiam: o légein como o lugar que concentra, o centro predominante que tudo reúne e para onde tudo converge de modo mais originário de modo a fazer surgir por si mesmo no desencoberto; e o noeîn como um perceber que tem como traço o pressentir de algo que vem até nós, nos sobrevém e se oferece à atenção para que aí o retenhamos. Trata-se de um recolher-perceber. Nessa relação, há o desdobrar-se de um em relação ao outro, o movimento mútuo de um para o outro e do outro para um. Não

\footnotetext{
${ }^{537}$ HEIDEGGER, "Sobre a essência da verdade", in:

${ }^{538}$ HEIDEGGER, “A essência da linguagem”, in: Os Pensadores, p.162. A Caminho da Linguagem, p. 170.
} 
no sentido de uma mera junção de termos, mas de uma interação, entrelaçamento, mútua reciprocidade, copertença - uma autêntica relação de articulação. Mas o que diz essa relação? A ligação do noûs com o lógos instaura o vigor do ser em sua unidade de reunião. Com isso, preserva e faz prevalecer a verdade do ser. Como dissemos, não se trata da relação entre dois polos, mas daquela em que a essência do homem toma parte e se firma na relação com o seu ser. É somente na medida em que o homem se põe à escuta obediente que ele está aberto para o ser e pelo ser. Referimo-nos a algo que jamais pode ser apreendido - à relação do ser com a essência humana, à dobra entre ser e ente. ${ }^{539}$ A partir da articulação de ambos, compreende-se o que mais tarde chamou-se de aletheúein: "desvelar e manter desvelado o que se oculta" ${ }^{540}$ Há, portanto, na relação do légein com o noeîn uma correspondência com aquilo que se oculta - o próprio ser - de modo a institui-lo na presença. Dito nas palavras de Heidegger: “o recolhimento no ser conduz o ser para o desencobrimento, de tal maneira que em cada coleta e recolhimento se colhe o ser num ente que surge, deixando surgir na limitação do seu próprio contorno [...] o ser desencoberto." ${ }^{541}$ É este agir, que se passa na relação do ser com o homem que é o mais elevado, pois o noeîn deixa-se convocar pelo ser para dizer sua verdade. Isto faz brotar a palavra original. A essência da linguagem se dá como poder criador do mundo, sem a palavra nada há. Por isso iniciamos este capítulo com as palavras de João sobre o lógos. É o lógos que recolhe na palavra o ser e o conduz para a palavra. Esta é uma dimensão em que a palavra é palavra e só palavra. Esta é a hora do nome e a hora da coisa. A linguagem originária, a linguagem em sentido próprio, só se dá onde o vigorar do ser é ofertado à intangibilidade superior da palavra originária. ${ }^{542}$ Esta é a poética da palavra. Esta é a linguagem da poesia. Na experiência poética da linguagem a fala não é sinal, não é uma referência, é a própria coisa. Reforçamos a ideia de que se trata de um modo originário do poetar, cuja essência poetante refere-se ao dizer do ser, pois é somente no ser que a linguagem é exemplarmente

\footnotetext{
${ }^{539}$ Cf. HEIDEGGER, Heráclito, p.305-306.

${ }^{540}$ HEIDEGGER, Que Chamamos Pensar? [inédito], p.177. Em nossa dissertação de mestrado, trabalhamos o fragmento VI da sentença de Parmênides: Chré tó légein te noeîn t'eòn émmenai (É preciso dizer e pensar que o ente é [...]), que ficou traduzida por Heidegger por: "É preciso deixar assentar diante de nós e prestar atenção ao presentificar-se do que se faz presente." Tal compreensão nos é dada através de um longa e exaustiva análise que deslocam os verbos légein e noein de seus sentidos habituais, a saber, dizer e pensar, e os envia à categoria das palavras essenciais. (Cf. KAMPFF, Heidegger e o outro pensar, p.133-164.)

${ }^{541}$ HEIDEGGER, op. cit., p.376.

${ }^{542}$ Cf. HEIDEGGER, Lógica, p.255-256.
} 
linguagem. ${ }^{543}$ Aqui o poetar se reporta a uma dimensão originária que é previamente orientada pelo ser. O que o poeta faz é acolher e reportar-se a essa origem, lugar em que o ser vigora, e, neste movimento, ele revigora a linguagem. $\mathrm{O}$ ato de criação é a estrutura desse movimento de diferenciação, que é a retomada e ao mesmo tempo a transformação do originário. Esta será sempre uma linguagem original, inaugural com o surgimento das coisas - da força fundadora e instauradora da realidade - da genuína linguagem que se faz desde como experiência da linguagem. Trata-se, por outras palavras, de um processo de explicitar o surgimento do real e o compassamento desse surgimento com o dizer, com a fala. Quando Caeiro diz: "As coisas não têm significação: têm existência" ${ }^{544}$, ele fala da total experiência fenomenológica do ver imediato, lugar onde as coisas são sempre a presença vigente de um sentido que o dizer originário mostra. Quando a fala está sintonizada com essa irrupção, a fala põe a coisa tal como ela é. Isto quer dizer que quando o poeta se põe na palavra, que é a fala da experiência, a palavra e a coisa são um único e mesmo ato. Por isso, podemos afirmar com Caeiro que, na experiência da poética do ver imediato e do dizer como mostrar, as coisas não têm significação, tem existência. As coisas são. Esta unidade de integração de todas as coisas se impõe sobre o poeta. Ele não pode não ver. Nessa integração de tudo ele é todas as coisas.

Por tudo o que vimos e ouvimos, podemos afirmar que a poesia de Caeiro é uma retomada do que Heidegger pensa como linguagem. O poeta é este que se faz neste modo de ser que vem a ser em se fazendo e, nesse trabalho histórico, constrói a linguagem criadora, originária. Ele é livre para poder ser e vai, assim, se realizando. Caeiro diz, em 1922:

[...] O vento sopra sem saber.

A planta vive sem saber.

Eu também vivo sem saber, mas sei que vivo.

Mas saberei que vivo, ou só saberei que o sei?

Nasço, vivo, morro por um destino em que não mando,

Sinto, penso, movo-me por uma força exterior a mim. $[\ldots]^{545}$

Caeiro é, pois, aquele que acolhe o seu destino, o envio da palavra poética. Nisso há uma memória, a reunião das lembranças, a salvaguarda do imemorial que se oculta e retrai, mas que mantém o apelo da presença em favor do ente como dádiva.

\footnotetext{
${ }^{543}$ HEIDEGGER, “O Dito de Anaximandro”, in: ___ Caminhos de Floresta, p. 380.

544 PESSOA, Obra Poética, p.223; idem, Obra Completa de Alberto Caeiro, p.66.

545 PESSOA, Obra Completa de Alberto Caeiro, p.113-114.
} 
Ser poeta é a possibilidade de recordar e entrever isso que já se deu, lugar em que impera a força desse aparecer como uma ausência. O dizer poético é a saga do mostrar (e não mostrar) que se desdobra em linguagem. Nisso não tem cronologia. Entram em jogo o ter-sido, o instante atual e o porvir. O poetar como destino acontece numa temporalidade toda própria - o porvir se volta ao cerne do ter-sido e o ter-sido se estende em direção ao cerne do porvir, no instante atual. ${ }^{546}$ Por outras palavras: no instante criativo, o poeta retoma o ter-sido em um salto retrospectivo que busca na origem o impensado e se lança para o porvir na palavra anunciadora - “o dizer projectante é poesia" ${ }^{547}$, diz Heidegger. Esta é a justa medida, plena, apropriada, a única capaz de deixar-ser cada coisa no vigor de seu próprio ser. O poetar que faz isso é perfeito. É tudo o que pode ser, pois é somente onde o ser se manifesta que a voz pode ser palavra. ${ }^{548}$ Não há voluntarismo sobre isso. Vive-se sem saber. Caeiro é atravessado e movido por isso que é puro acontecimento! A irrupção deste acontecimento é uma experiência de linguagem - de harmonia e consonância com o lógos, com a phýsis e com a alétheia - a única experiência capaz de dizer o que está manifesto diante dos olhos, de transpor a visão livre daquilo que se manifesta em si mesmo para a palavra. Tudo isso é luminosidade, é luz radiante, clareza, limpidez; é vigor, pulsação, expansão e contensão armazenados no interior de uma tensão harmoniosa. Tudo isso é concentração viva do sentido da vida. É, como diz Harada, "a presença da intensidade do ser como a dimensão concretizada da profundidade humana. ${ }{ }^{4} 9$ É a curiosa complexa simplicidade de Caeiro que vive a concreção do sentido pleno de ser, a consumação da obra da vida que culmina com a obra do poetar. A ação disso é linguagem, é a autorrealização do homem, da existência, da história. É aquilo que nos anuncia Campos, em carta a Caeiro: "o único destino digno dum poeta." ${ }_{550}$

\footnotetext{
${ }^{546}$ Cf. HEIDEGGER, As Questões Fundamentais da Filosofia, p.46-59.

${ }^{547}$ HeIDEGGER, A Origem da Obra de Arte, in:__ Caminhos de Floresta, p.79.

${ }^{548}$ Cf. HEIDEGGER, Introdução à Metafisicica, p.157.

${ }^{549}$ HARADA, Iniciação à Filosofia, p.238.

${ }^{550}$ PESSOA, Poemas Completos de Alberto Caeiro, p.231.
} 


\section{5 \\ Considerações finais}

Words strain,

Crack and sometimes break, under the burden,

Under the tension, slip, slide, perish, Decay with imprecision, will not stay in place,

Will not stay still. Shrieking voices

Scolding, mocking, or merely chattering,

Always assail them. The word in the desert Is most attacked by voices of temptation

The crying shadow in the funeral dance,

The loud lament of the disconsolate chimera.

- T. S. Eliot ${ }^{551}$

Como diz Eliot no poema, as palavras tentam. Nossas palavras tentaram. Este não foi um caminho fácil, mas chegamos as nossas palavras finais. Não se trata, porém, de um final conclusivo. Daqueles que nos levam a um fechamento no sentido de um entendimento definitivo, amarrado. Sabemos que há uma circularidade no pensar de Heidegger, que, a cada volta, adensa ainda mais a questão, e mesmo a mais exaustiva análise termina com uma indagação, aponta um outro caminho. Assim é a filosofia: sempre uma árdua tentativa. As palavras, diz Eliot, "resvalam, decaem, perecem com imprecisões." Além da dura lida com as palavras, a interpretação é atravessada pela tentação de submetermos o lido a algo previamente pensado. Ouvimos as palavras de Gadamer em nossa introdução: não há como manter uma neutralidade, muito menos a anulação de si mesmo. Evitar esta sedução foi um exercício constante de nossa parte. Por outro lado, também temos em mente que penetrar um pensamento sem nenhum pressuposto é, na visão de Heidegger, uma teimosia infundada, pois, a ausência de pensamento acaba por nos levar ao reino da adequação e isto evitamos a todo custo! Voltamo-nos para os poemas pessoanos não para falar sobre eles. Sua métrica, rima ou o saltitar dos seus versos passaram ao largo do nosso olhar. A rima, diz Mora, “é uma doença do ritmo [...] as regras apertadas - longe de serem um sinal de força, são um sinal de

551 ELIOT, Poemas, p.234-237. Tradução de Caetano W. Galindo: "Palavras tentam, / Tensas, chegam a quebrar, com o fardo / A pressão, deslizam, resvalam, perecem, / Decaem com imprecisões, se negam a restar, / Se negam a parar, Agudas vozes que / Ralham, que riem, ou somente falam, / Assolam-nas sempre. / O Verbo no deserto / É mais o alvo de vozes tentadoras, / Gritante sombra no balé funéreo, / Lamento estrondoso da aflita quimera.” 
fraqueza." ${ }_{552}$ Buscamos, sim, confrontar os textos e os poemas respeitando-os em suas alteridades, procurando ouvir suas palavras a partir de um frescor todo próprio que, apesar de inaudíveis, clamam por um dizer. Ainda que este tenha sido o nosso desejo, diz Heidegger, sobre o limite da interpretação:

A interpretação de um poema vê-se, assim, colocada perante problemas muito particulares: por um lado, o de compreender o contexto da acção, indicado pelas imagens, em si, quanto ao seu conteúdo intuitivo próprio, mas a seguir, o de ver este conjunto como um renegar e um afastamento do que há propriamente para dizer. Nisto está, ao mesmo tempo, contida a questão de saber se aqui - perante um dizer poético assim constituído - a interpretação não atinge um limite de princípio, e de que tipo é esse limite. ${ }^{553}$

Trata-se, portanto, de compreendermos que a tarefa a qual nos propusemos realizar é perpassada por um dizer que possui um limite - um limite do próprio do dizer, da limitante precariedade de pronunciar a palavra. A palavra foi inventada para ser calada, teria dito uma poeta. Chegamos, pois, ao limiar da porta. Chegamos as nossas palavras finais sobre a pretensão de apresentar o entrelaçamento do pensamento filosófico de Martin Heidegger e da poética de Fernando Pessoa, no que diz respeito à linguagem originária.

Iniciamos nossa trajetória falando sobre a indigência do tempo que caracterizava o início do século passado. Detivemo-nos alongadamente na questão do niilismo existencial trazido pela ausência dos pilares religiosos, filosóficos, científicos e políticos. Falamos de uma época do mundo em que não há fundo ou fundamento. Suspensos no abismo do mundo encontram-se os poetas e os filósofos. São eles que de forma análoga, mas não igual, falam da essência das coisas. ${ }^{554}$ São os poetas do tempo indigente que, nas palavras do pensador alemão, vivem a experiência do abismo e do declínio, da carência e da escuridão, lugar em que o silêncio e a escuta se impõem num modo de abertura lançando o poeta irrevogavelmente ao envio do seu destino. A tarefa do poeta é cultivar a palavra, e, nessa lida, dar a ver no dizer - como dizer e desde o dizer. Na poesia esse tornar visível, esse realizar presença, se dá enquanto e como palavra. O poeta é aquele que tem na palavra o acontecimento da verdade, é aquele que se ocupa da linguagem, de tal modo, que neste acontecimento a palavra aparece como se fosse pela primeira

\footnotetext{
${ }^{552}$ MORA, "Fundamentos do Paganismo", in: PESSOA, O Regresso dos Deuses, p.194.

${ }^{553}$ HEIDEGGER, Hinos de Hölderlin, p.116.

${ }^{554}$ Cf. Ibidem, p.47.
} 
vez. Isto é linguagem no sentido arcaico, originário. Este é um exercício de liberdade de uma língua. Nisto está a transformação contra a homogeneização, contra a pasteurização, contra a cristalização da linguagem e do próprio homem. Poeticamente habita o homem na terra, ouvimos de Hölderlin. O viver, o habitar do homem no mundo, é um fazer, um ouvir, um seguir e obedecer. Este modo de ser que é deixar ser ou deixar aparecer, é passagem para o poético. Isso se impõe sobre o poeta. Ele não pode não ser assim. O poeta escreve a partir dessa experiência. É somente a partir da experiência da poética da palavra, a partir da possibilidade de ser tocado e tomado pela palavra como princípio de realidade, de geração, que se pode falar. A palavra como poética, como realização de realidade, mostra uma dimensão, um horizonte, uma perspectiva do real no seu todo. Mostra o ente em sua totalidade. Sobre isto não há domínio ou controle. A poesia tem que ser sempre escrita a partir dela mesma. Se isso acontece, a palavra originária irrompida dessa experiência não é sinal, não é símbolo, não é referência, ela é a própria coisa, o momento de gênese: onde nome e a coisa são uma só e mesma coisa, em um só e mesmo ato. Daí a compreensão de que a poesia habita na linguagem e que o poema é o seu estado mais puro - lugar em que palavra é exemplarmente palavra. Ouçamos os versos de Caeiro, escritos em 1919:

Para mim, graças a ter olhos só para ver, Eu vejo ausência de significação em todas as cousas;

Vejo-o e amo-me, porque ser uma cousa é não significar nada. Ser uma cousa é não ser susceptível de interpretação. ${ }^{555}$

Ou, mesmo, rememoremos os versos:

A espantosa realidade das coisas

É a minha descoberta de todos os dias.

Cada coisa é o que é,

E é difícil explicar a alguém quanto isso me alegra,

E quanto isso me basta. ${ }^{556}$

Na primeira estrofe, vamos encontrar, em oposição à ausência de significação, a visão do ver, o ver inaugural, o ver que sente a coisa. A segunda, nos confirma a espantosa realidade da coisa ser aquilo que é, nem mais nem menos. O problema é entendermos o que é coisa. Coisa, como vimos, não é o que o nosso olhar adormecido constata. Isso não é coisa! Para nos acercarmos da coisa, diz Heidegger, “o primeiro passo na direção dessa vigília é o passo atrás, o passo que passa de um

${ }_{555}$ PESSOA, Obra Poética, p.233; idem, Obra Completa de Alberto Caeiro, p.106.

${ }^{556}$ Ibidem, p.234; ibidem, p.91. 
pensamento apenas representativo, isto é, explicativo, para o pensamento meditativo, que pensa o sentido." ${ }^{557}$ O pensamento que pensa o sentido é o pensar que sente, que vê sem imagem, que vê o ver, e isso só acontece quando o pensamento entra no seu elemento mais próprio. Dentro deste âmbito, a coisa é o próprio aparecer, é o próprio real. É dessa experiência de linguagem que Heidegger se refere quando fala:

O homem é aquele que diz. Dizer no alemão arcaico sagan, significa: mostrar, fazer aparecer e ver. O homem é o ser que pelo dizer faz surgir o presente em sua presença [...]. Apenas lá onde o desvelamento já impera, algo pode tornar-se visível, mostrável, perceptível. ${ }^{558}$

Esse deixar-aparecer é sempre uma coisa extraordinária. Não é nem passividade e nem atividade. É ser que deixa-ser. É silêncio. É escuta e espera. Corporeidade. É pura possibilidade de ser tocado e tomado. É irrupção. Desocultação. Mas é também velamento. É saber que nessa retração também impera seu poder e força e que nesse habitar encontra-se o mistério, o qual jamais deixa-se apreender através de uma representação, mas se põe como questão para o pensamento, pois é somente este, o pensamento, o único capaz de pôr-se em via de tudo isso.

A poesia de Pessoa carrega esta força. Além do inegável valor literário, a obra pessoana possui uma riqueza filosófica tão profunda que, mesmo sem estabelecer uma sistematização, a potência filosófica contida na estrutura interna dos poemas nos impele ao congraçamento com o pensamento heideggeriano. O próprio Pessoa reconhece que "era um poeta impulsionado pela filosofia, não um filósofo dotado de faculdades poéticas. (Que) adorava admirar a beleza das coisas, descortinar no imperceptível, através do que é diminuto, a alma poética do universo. ${ } 559$ Foi este o caminho filosófico que tentamos percorrer. Como dissemos no início, não estivemos aqui a analisar a obra pessoana poeticamente. Nosso intuito foi falar de linguagem originária a partir de Heidegger e de Pessoa. Buscamos na poesia pessoana e no pensamento heideggeriano os elementos para uma compreensão do que seja a linguagem em sua origem. Neste sentido, a poesia de Pessoa, Caeiro, Campos, Reis e todos os seus outros, não é senão o jogo da criação poética fundante da palavra e na palavra. Especialmente Caeiro. E não poderia não ser! Ele é o mestre de todos os poetas, incluindo Pessoa. Seus poemas ressoam,

\footnotetext{
${ }^{557}$ HEIDEGGER, “A Coisa”, in: ___ Ensaios e Conferências, p.159.

${ }^{558}$ HEIDEGGER, "Hegel e os gregos”, in:___ Marcas do Caminho, p.451.

${ }^{559}$ PESSOA, Páginas Íntimas e de Auto-Interpretação, p. 14.
} 
reverberam, de forma contundente, com aquilo que Heidegger pensou sobre linguagem originária. É a partir desta experiência e nesta proximidade que o poeta alcança a origem, regressa à casa. Na poesia de Caeiro experimentamos poeticamente a linguagem em sua origem. São seus poemas que tornam a língua possível pela primeira vez. "O poeta”, diz Heidegger,

nomeia todas as coisas naquilo que elas são. Este nomear não consiste em prover de um nome algo já previamente conhecido. Ao contrário, pela nomeação o ente é nomeado no que ele é, pela primeira vez, conforme o poeta diz a palavra essencial. Assim, o ente se dá a conhecer como ente. ${ }^{560}$

A poesia de Caeiro é, pois, a própria linguagem originária que, ao nomear pela primeira vez, funda o ser do ente. Caeiro, nos diz Pizarro, "vem renomear o mundo, mas fá-lo como se tal acto, de natureza estética fosse natural, e não carecesse de metáforas, de figurações e de artifícios, mas apenas e simplesmente da inocência do não pensar [...]." ${ }^{{ }^{561}}$ Este não é um caminho fácil. Trata-se de uma verdadeira saga. Nela, o poeta há que experimentar o abismo do nada da angústia existencial para que um tal modo de ser venha sobre ele, dele se aproprie, se apodere, e, de tal modo, que ele não possa não ser isto que o atravessa. Esta dimensão do aberto que chega até ele lhe pertence constitutivamente, mas ele não tem poder sobre isso, ele não é o autor disso. Sua grandeza é acolher isto que o ultrapassa e transcende - o raio divino que o atinge -, e ser a hora e o lugar da eclosão do sagrado: ser poesia! Isto é envio, é história: um destino regido pelos deuses. ${ }^{562}$ Lembremos que Caeiro é pagão. "Foi a sensibilidade pagã que renasceu nele. Não a inteligência pagã" ${ }^{563}$, diz Mora. Na realidade, no caso do guardador de rebanhos, trata-se de um neopaganismo que "nasce da atribuição a cada objeto da sua realidade verdadeira" ${ }^{564}$. Isto quer dizer que a realidade é o desvelar de cada coisa na coisa que é, o lugar em que "os deuses são fruto do ingénuo espanto humano ante a assombrosa realidade das cousas" ${ }^{565}$, diz Mora. Lembremos que, para o grego, um deus não era uma entidade, algo criado pela imaginação do homem. Um deus grego, esclarece Fogel,

constitui-se numa forma, numa estrutura, isto é, uma dinâmica de junção, de composição (synthesis), de integração ou de compactação (é isso mesmo a ação de lógos) e, desse modo, numa gênese ontológica ou na geração de um campo visual,

\footnotetext{
${ }^{560}$ HEIDEGGER, Explicações da Poesia de Hölderlin, p.51.

${ }^{561}$ PIZARRO, "Alberto Caeiro", in: PESSOA, 136 pessoas de Pessoa, p. 382.

${ }^{562}$ Cf. MORA, "Fundamentos do Paganismo", in: PESSOA, O Regresso dos Deuses, p. 171

${ }^{563}$ MORA, "Prefácio à obra de Alberto Caeiro", in: Ibidem, p.109.

${ }^{564}$ PESSOA, Páginas Íntimas e de Auto-Interpretação, p. 286.

${ }^{565}$ MORA, "Fundamentos do Paganismo", in: PESSOA, O Regresso dos Deuses, p.169.
} 
de um âmbito do aparecer ou do mostrar-se - um âmbito de verdade, de alétheia. Assim, um deus, uma divindade, constitui-se num arché-tipo, ele ou ela é archétípica $(o) .{ }^{566}$

Isto significa que a divindade era um modo de ser vida, um modelo, uma exemplaridade da existência. É nesta dimensão que homens e deuses se encontram no mundo grego. É nesta dimensão que Caeiro "aparece" no tal dia triunfal: como "uma epifania mais próxima do mito da inspiração divina" 567 , diz Pizarro. É através do ver que vê "a espantosa realidade das coisas" que Caeiro nomeia o mundo. Se Hölderlin foi para Heidegger o poeta dos poetas pelo fato de poematizar a essência da poesia. ${ }^{568}$ Podemos dizer que Caeiro é o poeta da linguagem ao poematizar com tamanha simplicidade a essência da linguagem, a força que gera o seu aparecer autêntico, o nomear que funda o ser e a essência de todas as coisas e as traz ao aberto pela primeira vez.

Heidegger e Pessoa - e toda a sua coterie - se encontram na linguagem original. Ambos, filósofo e poeta, dizem o mesmo de formas distintas: o poeta canta o ser ao nomear as palavras e o pensador chega ao ser a partir do seu pensar. Ambos falam a partir da mesma clareira. ${ }^{569}$ "O $\mathrm{O}$ que falam os poetas? O que falam os pensadores?", indaga Hüne. A intérprete esboça uma resposta: “Simplesmente acolhem a verdade que decorre de uma posição de desvelamento e de abertura, onde o ser e o tempo se ligam, dando origem à Palavra." 570 Palavra que, como vimos, é o lugar em que a linguagem é o advento que ilumina e vela o próprio ser. ${ }^{571}$ Quando o pensar e o dizer acercam-se de sua morada apropriam-se do simples, e aí o pensar não é Filosofia e o dizer não é Literatura, mas apenas e simplesmente a linguagem do ser, "como as nuvens são as nuvens do céu."

\footnotetext{
${ }^{566}$ FOGEL, Desaprendendo o Símbolo, p.92-93. Itálicos do autor.

${ }^{567}$ PIZARRO, "Alberto Caeiro", in: PESSOA, 136 pessoas de Pessoa, p.383.

${ }^{568}$ Cf. HEIDEGGER, Explicações da Poesia de Hölderlin, p.44.

${ }^{569}$ Cf. HÜNE, "Introdução", in: BERARDINELLI et alii, Fernando Pessoa e Martin Heidegger: $O$ Poetar Pensante, p.13-15.

${ }^{570}$ Ibidem, p. 15.

${ }^{571}$ Cf. HEIDEGGER, Sobre o Humanismo, p.45.

572 Ibidem, p. 100.
} 
6

\section{Referências Bibliográficas}

ARISTÓTELES, De Anima. Trad. Maria Cecília Gomes dos Reis. São Paulo: Editora 34, 2017.

Poética. Trad. Paulo Pinheiro. São Paulo: Editora 34, 2017.

ARENDT, H. A Condição Humana. Rio de Janeiro: Forense Universitária, 2005. ; HEIDEGGER, M. Hannah Arendt - Martin Heidegger:

Correspondência 1925/1975. Org. Ursula Ludz. Rio de Janeiro: Relume Dumará, 2001.

Thinking without a Banister: Essays in understanding, 1953-1975. Ed. Jerome Kon. New York: Schoken Books, 2018.

BAMBACH, C. Heidegger, Dilthey and the Crisis of Historicism. Ithaca: Cornell University Press, 1995.

BARROSO, I. “O Corvo” e suas traduções. São Paulo: SESI-SP, 2018.

BARTHES, R. Aula. Trad. Leyla Perrone-Moisés. São Paulo: Cultrix, 1980.

. Image Music Text. Trad. Stephen Heath. London: Fontana Press, 1977.

O Prazer do Texto. Trad. J. Guinsburg. São Paulo: Perspectiva, 1987.

BECKETT, S. O Inominável. Trad. Waltensir Dutra. Rio de Janeiro: Nova Fronteira, 1989.

BENJAMIN, W. Escritos sobre Mito e Linguagem. Trad. Suzana Kampff Lages e Ernani Chaves. São Paulo: Duas Cidades; Editora 34, 2013.

. O Anjo da História. Trad. João Barrento. Belo Horizonte: Autêntica, 2016.

Obras Escolhidas I: Magia e Técnica, Arte e Política. São Paulo:

Brasiliense, 2012.

BERARDINELli, C. et alii. Fernando Pessoa e Martin Heidegger: O Poetar

Pensante. Org. Leda Miranda Hühne. Rio de Janeiro: Uapê, 1994.

. Fernando Pessoa: Outra Vez te Revejo... Rio de Janeiro: Nova Aguillar, 2004.

BICCA, L. O Mesmo e os Outros. Rio de Janeiro: Sete Letras, 1999.

BÖLTING, R. Dicionário Grego-Português. Rio de Janeiro: Instituto Nacional do Livro, 1953.

BRANDÃO, J. Mitologia Grega. Volume I. Petrópolis: Vozes, 1986.

BRÉCHON, R. Estranho Estrangeiro: Uma biografia de Fernando Pessoa. Trad. Maria Abreu e Pedro Tamen. Rio de Janeiro: Record, 1999.

CANDIDO, A. Literatura e Sociedade. Rio de Janeiro: Ouro sobre Azul, 2006. 
CARNEIRO LEÃO, E. "Itinerário do pensamento de Heidegger". In: Introdução à Metafísica. Trad. Emmanuel Carneiro Leão. Rio de Janeiro: Tempo Brasileiro, 1999.

. O último Heidegger: Ereignis por Parousia: Uma aproximação ao pensamento de Martin Heidegger [inédito].

CASSIRER, E. Linguagem e Mito. São Paulo: Perspectiva, 2006.

COELHO, J.P. Diversidade e Unidade em Fernando Pessoa. Lisboa: Verbo, 1973.

DESCARTES, R. Discurso do Método. Trad. Maria Ermantina Galvão. São Paulo: Martins Fontes, 2016.

DICKINSON, E. Emily Dickinson: Não sou Ninguém. Trad. Augusto de Campos. Campinas: Editora da Unicamp, 2015.

DUARTE, A. Heidegger e a linguagem: do acolhimento do ser ao acolhimento do outro. Revista Natureza Humana. v.7 n.1. São Paulo - Junho/2005.

ELIOT, T.S. Poemas. Trad. Caetano W. Galindo. São Paulo: Companhia das Letras, 2018.

ERNOUT, A.; MEILLET, A. Dictionnaire Etymologique de la Langue Latine: Histoire de Mots. Paris: Klincksieck, 2001.

FERNANDES, M. L. O. Leituras da Modernidade. Olho d'água, Revista do Programa de Pós-Graduação em Letras da UNESP/São José do Rio Preto, v.3, n.1, Janeiro-Junho, 2011.

FLAUBERT, G. Cartas Exemplares. Trad. Carlos Eduardo Lima Machado. Rio de Janeiro: Imago, 2005.

FOGEL, G. Da Solidão Perfeita: escritos de filosofia. Petrópolis, RJ: Vozes, 1998.

. Homem, Realidade, Interpretação. Rio de Janeiro, Mauad X, 2015.

. O Desaprendizado do Símbolo: ou da experiência da linguagem. Rio de Janeiro: Mauad X, 2017.

Sentir, Ver, Dizer: cismando coisas de arte e de filosofia. Rio de Janeiro: Muad X, 2012.

Sobre Homem e História. Rio de Janeiro: Mauad X, 2019.

FOTI, V. Heidegger and the Poets. New Jersey: Humanity Press International Inc, 1992.

FRIEDRICH, H. Estrutura Lírica Moderna (da metade do século XIX a meados do século XX). Trad. Marise M. Curioni. São Paulo: Duas Cidades, 1978.

GADAMER, H-G. Verdade e Método: Traços Fundamentais de uma Hermenêutica Filosófica. Trad. Flavio Paulo Meurer. Petrópolis: Vozes, 1999.

. Verdade e Método II: Complementos e Índice. Trad. Enio Paulo Giachini. Bragança Paulista: Editora Universitária São Francisco; Petrópolis: Editora Vozes, 2017. 
GIL, J. Cansaço, Tédio, Desassossego. Lisboa: Relógio D’Água, 2013.

. O Devir-Eu de Fernando Pessoa. Lisboa: Relógio D’Água, 2010.

HARADA, H. Coisas, velhas e novas: À margem da espiritualidade franciscana. Bragança Paulista: Edusf e Ifan, 2006.

et alii. Experimentar Deus Hoje. Petrópolis: Vozes, 1976.

" "Fenomenologia do Corpo: Situação como existência corporal. À guisa de uma fenomenologia da corporeidade". In: Revista Cultura Vozes. Petrópolis: Vozes, n. 65, 1971.

. Iniciação à Filosofia: Exercícios, ensaios e anotações de um principiante amador. Teresópolis: Daimon Editora, 2009.

HEIDEGGER, M. A Caminho da Linguagem. Trad. Márcia Sá Cavalcante Schuback. Petrópolis: Vozes; Bragança Paulista: Editora Universitária São Francisco, 2012.

A Origem da Obra de Arte. Trad. Maria da Conceição Costa. Lisboa: Edições 70, 1977.

As Questões Fundamentais da Filosofia. Trad. Marco Antonio Casanova. São Paulo: WMF Martins Fontes, 2017.

. Caminhos de Floresta. Trad. Irene Borges Duarte et alii. Lisboa: Fundação Calouste Gulbenkian, 2012.

Contribuições à Filosofia: Do acontecimento Apropriador. Trad. Marco Antonio Casanova. Rio de Janeiro: Via Verita, 2015.

. Ensaios e Conferências. Trad. Emmanuel Carneiro Leão, Gilvan Fogel e Márcia Sá Cavalcante Schuback. Petrópolis: Vozes; Bragança Paulista: Editora Universitária São Francisco, 2012.

Explicações da Poesia de Hölderlin. Trad. Claudia Pellegrini Drucker. Brasília: Editora UnB, 2013.

. Heráclito. Trad. Márcia Sá Cavalcante Schuback. Rio de Janeiro: Relume Dumará, 1998.

. Hinos de Hölderlin. Trad. Lumir Nahodil. Lisboa: Instituto Piaget, 2004.

. Interpretation of Nietzsche's Second Untimely Meditation Trans.

Ullrich Haase and Mark Siclair. Indiana: Indiana University Press, 2016.

. Introdução à Filosofia. Trad. Marco Antônio Casanova. São Paulo:

Martins Fontes, 2009.

Introdução à Metafísica. Trad. Emmanuel Carneiro Leão. Rio de Janeiro: Tempo Brasileiro, 1999.

. Língua de Tradição e Língua Técnica. Trad. Mario Botas. Lisboa: Passagens, 1995.

Lógica: A Pergunta pela Essência da Linguagem. Trad. Maria Adelaide Pacheco e Helga Hook Quadrado. Lisboa: Fundação Calouste Gulbekian, 2008. 
Marcas do Caminho. Trad. Enio Paulo Giachini e Ernildo Stein. Petrópolis: Vozes, 2008.

Nietzsche I . Trad. Marco Antônio Casanova. Rio de Janeiro: Forense Universitária, 2010.

. Nietzsche II. Trad. Marco Antônio Casanova. Rio de Janeiro: Forense Universitária, 2007.

. O acontecimento Apropriativo. Trad. Marco Antônio Casanova. Rio de Janeiro: Forense, 2013.

. O princípio do Fundamento. Trad. Jorge Telles Menezes. Lisboa: Piaget, 1999.

Ontologia: (Hermenêutica da Facticidade). Trad. Renato Kirchner.

Petrópolis: Vozes, 2012.

Os Conceitos Fundamentais da Metafísica: Mundo - Finitude - Solidão.

Trad. Marco Antônio Casanova. Rio de Janeiro: Forense Universitária, 2015.

Os Pensadores: Conferências e Escritos Filosóficos. Trad. Ernildo Stein.

São Paulo: Nova Cultural, 1996.

Parmênides. Trad. Sérgio Mário Wrublevski. Petrópolis: Vozes; Bragança Paulista: Editora Universitária São Francisco, 2008.

. Que Chamamos Pensar?. Trad. [inédita] Edgar Lyra, a partir de Was heist Denken?. Tübingen: Max Niemeyer, 1954.

. Que é uma coisa? Trad. Carlos Morujão. Lisboa: Edições 70, 2018.

. Seminários de Zollikon. Ed. Medard Boss; trad. Grabriela Arnhold e Maria de Fátima de Almeida Prado. Petrópolis: Vozes; Bragança Paulista: Editora Universitária São Francisco, 2009.

. Seminarios de Zollikon. Trad. Ángel Xolocotozi Yáñez. México: Herder, 2013.

Serenidade. Trad. Maria Madalena Andrade e Olga Santos. Lisboa: Piaget, 2000.

Ser e Tempo. Trad. Márcia Cavalcante Schuback. Petrópolis: Vozes;

Bragança Paulista: Editora Universitária São Francisco, 2012.

. Sobre a Essência da Linguagem: A respeito do tratado de Herder "Sobre a origem da Linguagem". Trad. Enio Paulo Giachini. Petrópolis: Vozes, 2015.

. Sobre o Humanismo. Trad. Emmanuel Carneiro Leão. Rio de Janeiro: Tempo Brasileiro, 2009.

Zollikon Seminars: Protocols - Converstion - Letters. Ed. Medard Boss. Trad. Franz Mayr and Richard Askay. Illinois: Northwestern University Press, 2001.

. “700 anos de Messkirch”. Trad. [Inédito] Gilvan Fogel, a partir de "700

Jahre de Messkirch”. In: Martin Heidegger zum 80. Geburtstag.

Frankfurt: Vittorio Klostermann, 1969. 
HERÁCLITO. Fragmentos: Os Pensadores Originários: Anaximandro, Parmênides, Heráclito. Trad. Emmanuel Carneiro Leão. Petrópolis: Vozes, 1991.

Heráclito: Fragmentos Contextualizados. Trad. Alexandre Costa. São Paulo: Odysseus Editora, 2012.

HUSSERL, E. A Crise da Humanidade Europeia e a Filosofia. Trad. Urbano Zilles. Porto Alegre: EDIPUCRS, 2008.

KAMPFF, V. Heidegger e o outro pensar: Uma leitura de Que chamamos pensar?. Rio de Janeiro: Ed. PUC-Rio; São Paulo: Ed. Reflexão, 2017.

KANT, E. Crítica da Razão Pura. Trad. Fernando Costa Matos. Petrópolis: Vozes; Bragança Paulista: Editora Universitária São Francisco, 2015.

KELLER, A. Michaelis: Pequeno dicionário: alemão-português, portuguêsalemão. São Paulo: Melhoramentos, 1994.

KIERKEGAARD, S. O Conceito de Angústia. Trad. Álvaro Luiz. Petrópolis: Vozes; Bragança Paulista: Editora Universitária São Francisco, 2013.

KLEE, P. Sobre a Arte Moderna e outros Ensaios. Trad. Pedro Süssekind. Rio de Janeiro: Zahar, 2001.

LIDDELL, H.G.; SCOTT, R. A Greek-English Lexicon. New York: Oxford University Press Inc., 1996.

LACOUE-LABARTHE, P. A Imitação dos Modernos: Ensaios sobre arte e filosofia. Trad. João Camillo Penna et alli. São Paulo: Paz e Terra: 2000.

LOPES, T. R. "Introdução ao(s) Livro(s) do Desassossego". In: Fernando Pessoa: O(s) Livro(s) do Desassossego. Ed. Teresa Rita Lopes. São Paulo: Global, 2015.

"O Seu a seu dono: Pessoa "desapossado" de Coelho Pacheco". In: JL Jornal de Letras, Arte e Ideias. No.1058, de 20 abril a 3 de maio de 2011. Disponível em: https://revistalusofonia.wordpress.com/2011/09/06/o-seua-seu-dono-pessoa-"desapossado"-de-coelho-pacheco/. Acesso em: 15 de maio de 2018.

Pessoa por Conhecer: Textos para um Novo Mapa. Lisboa: Estampa, 1990.

LORENZ, G. Diálogo com Guimarães Rosa. In: COUTINHO, E. (org.)

Guimarães Rosa. Rio de Janeiro: Civilização Brasileira, 1991.

LOURENÇO, E. Pessoa Revisitado. Rio de Janeiro: Tinta da China, 2017.

METELLO, F. M. C. Entrevistas. Lisboa: Portvgalia, 1923.

NIETZSCHE, F. Assim Falou Zaratustra: Um livro para todos e para ninguém. Trad. Paulo César de Souza. São Paulo: Companhia das Letras, 2011.

. A Vontade de Poder. Trad. Marcos Sinésio Pereira Fernandes e Francisco José Dias de Moraes. Rio de Janeiro: Contraponto, 2008.

OLSON, C. Human Universe and Other Essays. New York: Grove Press, 1967.

ORTEGA Y GASSET, J. La Idea de Principio en Leibniz y la Evolución de la

Teoría Deductiva. Buenos Aires: Emecé Editores, 1958. 
. Meditação da Técnica: Vicissitudes das Ciências. Cacofonia na Física. Rio de Janeiro: Livro Ibero-Americano Limitada, 1963.

. Obras Completas. Tomo I. Madri: Revista de Occidente, 1966.

. Obras Completas. Tomo VIII. Madri: Revista de Occidente, 1965.

O homem e os outros. Trad. Felipe Denardi. Campinas: Vide Editorial, 2017.

. O que é filosofia? Trad. Felipe Denardi. Campinas: Vide Editorial, 2016.

OSAKABE, H. Fernando Pessoa: Entre Almas e Estrelas. São Paulo: Iluminuras, 2013.

. Fernando Pessoa: Resposta à Decadência. São Paulo: Iluminuras, 2013.

OTTO, R. O Sagrado: Os aspectos irracionais na noção do divino e sua relação com o racional. Trad. Walter O. Schlupp. São Leopoldo: Sinodal/EST; Petrópolis: Vozes, 2007.

PASCAL, B. Pensamentos. Trad. Mário Laranjeira. São Paulo: Martins Fontes, 2005.

PAZ, O. A Busca do Presente. Trad. Eduardo Jardim. Rio de Janeiro: Bazar do Tempo, 2017. . "Fernando Pessoa: el desconocido de sí mismo". In: Fernando Pessoa Antologia. México: U.N.A.M., 1962.

O Arco e a Lira: Octavio Paz. Trad. Ari Roitman e Paulina Wacht. São Paulo: Cosac Naif, 2012.

PERRONE-MOISÉS, L. Fernando Pessoa: Aquém do eu, além do outro. São Paulo: Martins Fontes, 2001.

PERLOFF, M. O Momento Futurista: Avant-garde, avant-guerre e a linguagem da ruptura. Trad. Sebastião Uchoa Leite. São Paulo: Edusp, 1993.

PLATÃO. A República. Trad. Maria Helena da Rocha Pereira. Lisboa: Fundação Calouste Gulbenkian, 2017.

. Fedro. Trad. José Cavalante de Souza. São Paulo: Editora 34 Ltda., 2016. . Íon. Trad. Cláudio Oliveira. Belo Horizonte: Autêntica, 2011.

. Mênon. Trad. Maura Iglésias. Rio de Janeiro: Ed. PUC-Rio; Loyola, 2001. . O Banquete. Trad. José Cavalcante de Souza. São Paulo: Editora 34, 2016.

PESSOA, F. 136 pessoas de Pessoa. Ed. Jerónimo Pizarro e Patrício Ferrari. Rio de Janeiro: Tinta-da-China Brasil, 2017.

. Álvaro de Campos: Livro de Versos. Org. Teresa Rita Lopes. Lisboa: Estampa, 1993.

Cartas de Fernando Pessoa a Armando Côrtes-Rodrigues. Int. de Joel Serrão. Lisboa: Livros Horizonte, 1985.

. Escritos Íntimos, Cartas e Páginas Autobiográficas. Org. António

Quadros. Lisboa: Pub. Europa-América, 1986. 
Livro do Desassossego: composto por Bernardo Soares, ajudante de guarda-livros da cidade de Lisboa. Ed. Richard Zenith. São Paulo: Companhia das Letras, 2017.

. Livro(s) do Desassossego. Ed. de Tereza Rita Lopes. São Paulo: Global, 2015.

. Novas Poesias Inéditas. Ed. de Maria do Rosário Marques Sabino e Adelaide Maria Monteiro Sereno. Lisboa: Ática, 1993.

Obra Completa: Álvaro de Campos. Ed. de Jerónimo Pizarro e Antonio Cardiello. Lisboa: Tinta da China, 2014.

. Obra Completa de Alberto Caeiro. Ed. Jerónimo Pizarro e Patrício Ferrari. Lisboa: Tinta da China, 2016.

. Obra Completa de Ricardo Reis. Ed. Jerónimo Pizarro e Jorge Uribe. Lisboa: Tinta da China, 2016.

Obra Poética. Volume Único. Rio de Janeiro: Nova Aguillar, 1997.

. Obras em Prosa. Volume Único. Rio de Janeiro: Nova Aguillar, 1986.

. O Regresso dos Deuses: e outros escritos de António Mora. Lisboa: Assírio \& Alvim, 2013.

. Páginas de Pensamento Político. Vol. II. Org. António Quadros. Mem Martins: Europa-América, 1986.

. Páginas Íntimas e de Auto-Interpretação. Ed. de Georg Rudolf Lind e Jacinto do Prado Coelho. Lisboa: Ática, 1966.

. Poemas Completos de Alberto Caeiro. Org. Teresa Sobral Cunha. Lisboa: Presença, 1994.

Poesias. Lisboa: Ática, 1942.

. Poesias de Álvaro de Campos. Lisboa: Ática, 1993.

. Prosa Íntima e de Autoconhecimento. Ed. Richard Zenith. Lisboa: Assírio \& Alvim, 2017.

. Textos de Crítica e de Intervenção. Lisboa: Ática, 1980.

. Ultimatum e Páginas de Sociologia Política. Org. Joel Serrão. Lisboa: Ática, 1980.

. Vida e Obra de Alberto Caeiro. Org. Teresa Rita Lopes. São Paulo: Global, 2017.

. Vida e Obras do Engenheiro: Álvaro de Campos. Org. Teresa Rita Lopes. Lisboa: Estampa, 1990.

PIZARRO, J. 'Pessoa e 'Monsieur' Marinetti”. In: Estudos Italianos em Portugal, n.s., 4, 2009, p.77-88. Disponível em: https://digitalisdsp.uc.pt/bitstream/10316.2/42575/1/Pessoa_e_monsieur_marinetti.pdf Acesso em: 16 de julho de 2018.

RÉGIO, J. Pequena História da Moderna Poesia Portuguesa. Lisboa: Inquérito, 1941.

RICOEUR, P. Leituras 3: Nas Fronteiras da Filosofia. São Paulo: Loyola, 1996. 
ROBERT, P. Micro Robert: Dictionnaire du Français Primordial. Paris: Brodard et Taupin, 1981.

ROHDE, E. Psyche: The cult of Souls and the Belief in Immortality among the Greeks. Trans. W.B. Hillis. New York: Harcourt, Brace \& Company Inc., 1925.

SEABRA, J.A. Fernando Pessoa ou o Poetodrama. São Paulo: Perspectiva, 1991.

SENA, J. "21 dos 35 Sonnets de Fernando Pessoa”. In: Alfa, n.10, Marília, Setembro, pp. 7-24, 1966.

SCHLEGEL, F. O dialeto dos fragmentos. Trad. Márcio Suzuki. São Paulo: Iluminuras, 1997.

SNELL, B. The Discovery of the Mind: The Greek Origins of European Thought. Trans. T. G. Rosenmeyer. Massachusetts: Harvard University Press Cambridge, 1953.

SPENGLER, O. O Homem e a Técnica: Contribuição à uma filosofia de vida. Trad. Érico Veríssimo. Porto Alegre: Edições Meridiano, 1941.

VATtiMO, G. As Aventuras da Diferença. Trad. José Eduardo Rodil. Lisboa: Edições 70, 1980.

VOLPI, F. O Niilismo. Trad. Aldo Vannucchi. São Paulo: Ed. Loyola, 2012.

ZARADER, M. Heidegger e as Palavras de Origem. Trad. João Duarte. Lisboa: Instituto Piaget, 1990.

ZENITH, R. "Introdução", in: O Livro do Desassossego: composto por Bernardo Soares, ajudante de guarda-livros da cidade de Lisboa. Org. Richard Zenith. São Paulo: Companhia das Letras, 2011.

. "Sobre a heteronímia”. In: Prosa Íntima e de Autoconhecimento. Ed.

Richard Zenith. Lisboa: Assírio \& Alvim, 2017. 